UNIVERSIDADE DE SÃO PAULO

FACULDADE DE FILOSOFIA LETRAS E CIÊNCIAS HUMANAS

DEPARTAMENTO DE ANTROPOLOGIA

PROGRAMA DE PÓS-GRADUAÇÃO EM ANTROPOLOGIA SOCIAL

\title{
“... Da Força da Grana que Ergue e Destrói Coisas Belas": uma etnografia dos circuitos de lazer noturno em Londrina - PR a partir do Bar Valentino
}

Thomás Antônio Burneiko Meira

\begin{abstract}
Dissertação apresentada ao Programa de Pós-Graduação em Antropologia Social da Faculdade de Filosofia Letras e Ciências Humanas da Universidade de São Paulo, para a obtenção do título de Mestre em Antropologia Social.
\end{abstract}

Orientador: Prof. Dr. José Guilherme Magnani

São Paulo

2008 


\author{
UNIVERSIDADE DE SÃO PAULO \\ FACULDADE DE FILOSOFIA LETRAS E CIÊNCIAS HUMANAS \\ DEPARTAMENTO DE ANTROPOLOGIA \\ PROGRAMA DE PÓS-GRADUAÇÃO EM ANTROPOLOGIA SOCIAL
}

\title{
“... Da Força da Grana que Ergue e Destrói Coisas Belas": uma etnografia dos circuitos de lazer noturno em Londrina - PR a partir do Bar Valentino
}

Thomás Antônio Burneiko Meira

São Paulo

2008 


\section{AGRADECIMENTOS}

Ao longo dos quase três anos percorridos na elaboração desta dissertação, foram muitos aqueles que, de alguma forma, contribuíram para a sua realização e sem os quais a conclusão deste trabalho não teria sido possível.

Primeiramente, agradeço ao Prof. José Guilherme Magnani, meu orientador, não apenas por suas considerações nos momentos fundamentais do processo de pesquisa, mas também pela paciência e pela confiança ao longo de toda essa jornada.

Não posso deixar de agradecer também ao Prof. Heitor Frúgoli Jr. e à Prof. ${ }^{a}$ Fraya Frehse pelas valiosas críticas quando do exame de qualificação.

Alguns companheiros da pós-graduação foram fundamentais para a discussão e a troca de experiências na universidade e nos "bares da vida". Dentre estes, deixo meus agradecimentos especiais à Natacha, Ciça, Alê, César, Igor, Luís e Alex, com os quais compartilhei momentos de angústia e inquietação.

Fora do ambiente acadêmico, foram muitos os amigos e colegas com os quais dividi um lar, e, em alguns casos, um computador, neste período um tanto "nômade" de minha vida. Deixo aqui registrada à gratidão ao "Pedro Velho", Lílian, ao Renato "Perucón”, Bruno Rizzi, Fá, Keiko, Natália, Márcio "Mococa”, Wagner "Vaca”, Ana Ligia, Pedro e à Fernanda, em São Paulo; à Mauê, Ana Luíza, Bruno "Bergaminho", Charles "Macaco", e ao André "Rato de Esgoto", em Londrina; à Lisa "Doidinha", Lariane, Mariana Tralback, e à Amanda "Ama", por terem compartilhado seus computadores durante minhas visitas à Cianorte; e, finalmente, ao Gabriel "Magrão", em Maringá.

Em Londrina, agradeço também aos proprietários e aos funcionários do Bar Valentino - especialmente ao Chammé, Márcio, "Preá", Juninho, "Buda" e ao "Bruninho" -, pela disposição e pelo acesso privilegiado que me proporcionaram ao bar, e à Vanda de Moraes, diretora de patrimônio artístico e histórico-cultural do município, por gentilmente ter me cedido algumas plantas e ilustrações.

Expresso aqui também minha gratidão a CAPES, que me forneceu a bolsa de mestrado durante boa parte da pesquisa. 
Sem o auxílio emocional e financeiro de minha mãe, Sandra, de meu pai, Meira e de meus irmãos, Bruna e Guilherme, certamente essa pesquisa não teria sido concluída; por isso, deixo aqui um agradecimento especial a todos eles.

Finalmente, agradeço à Ana Laura "Guava", pela companhia, pelo carinho e pela paciência nestes últimos três anos. 


\section{RESUMO}

Desde a inauguração do Bar Valentino, em 1979, foi construída uma relação muito íntima entre seu espaço e o desenvolvimento das manifestações artísticas na cidade de Londrina, localizada ao norte do estado do Paraná. Pelas referências artísticas que adquiriu ao longo do tempo e por sua localização central, o Bar Valentino tornou-se um dos principais pontos de encontro de Londrina, aglutinando grupos de jovens provenientes de diversas áreas da cidade, configurando-se como um espaço de confluência entre seus circuitos. Em 2006, devido à venda do terreno onde o espaço permaneceu por 27 anos, o Bar Valentino abandonou o centro da cidade, transferindo-se para um bairro relativamente nobre, de forma que tais circuitos foram reconfigurados. Dada esta situação, esta pesquisa teve por objetivo identificar e interpretar tanto os antigos como os atuais circuitos dos freqüentadores deste espaço, relacionando-os à atual fase de crescimento e expansão da cidade de Londrina, tanto no plano físicoespacial quanto no da sociabilidade.

Palavras-chave: Londrina, Bar Valentino, circuitos, lazer, sociabilidade. 


\begin{abstract}
Since the opening of the Bar Valentino, in 1979, has built a cozy relationship between its space and the development of artistic events in the city of Londrina, located on the north of the state of Paraná, Brazil. For the artistic references that acquired over time and by its central location, the Bar Valentino has become a main point of meeting of Londrina, joined groups of young people from different areas of the city, setting itself as an area of confluence between its circuits. In 2006, due to the sale of the land where the space remained for 27 years, the Bar Valentino abandoned the city center, moving to a neighborhood relatively noble, so that such circuits were reconfigured. Given this situation, this study aimed to identify and interpret both old and current circuits of visitors on this area, linking them to the current phase of growth and expansion of the city of Londrina, both physical and space scope as the sociability.
\end{abstract}

Key-words: Londrina, Bar Valentino, circuits, leisure, sociability. 


\section{SUMÁRIO}

INTRODUÇÃO

\section{TENDÊNCIAS NO DESENVOLVIMENTO}

SÓCIO ESPACIAL DE LONDINA

1.1 A Ocupação do Norte Paranaense e a Atuação

da Companhia de Terras Norte do Paraná.

1.2 Configurações Iniciais da Paisagem Urbana Londrinense....................25

1.3 O Ápice e o Declínio da Cafeicultura Norte Paranaense

e suas Implicações nas Relações Sócio-Espaciais em Londrina.

1.4 Tendências Recentes de Expansão da Malha Urbana

Londrinense.

2. O BAR VALENTINO NO CENTRO

2.1 A “Cena” Artística Londrinense e a História do Bar Valentino.

2.2 O Bar Valentino e os Circuitos no Centro..............................................66

2.2.1 Bar Valentino: “Para Quem está In, Out, Up and Down”.............66

2.2.2 Os Trajetos e os Circuitos no Centro..............................................78

2.3 Os Últimos Anos no Centro: Dos Cadernos de Cultura

às Páginas Policiais

3. O NOVO BAR VALENTINO. 106

3.1 A Transferência do Bar Valentino:

"... Da Força da Grana que Ergue e Destrói Coisas Belas". 106

3.2 O Novo Bar Valentino e a Reconfiguração dos Circuitos

3.2.1 O Novo Bar Valentino: "Balada" na Boate,

Boemia na Casinha e o Controle Associado à Segurança.................114

3.2.2 A Reconfiguração dos Circuitos 


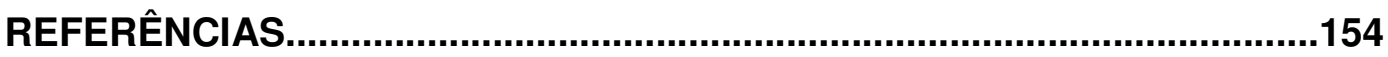

OUTRAS FONTES DE PESQUISA...............................................................159 


\section{INTRODUÇÃO}

Londrina é uma cidade média, com pouco mais de sete décadas de existência e aproximadamente meio milhão de habitantes. Localizada no chamado "Norte Central do Paraná”, ocupa uma posição estratégica em termos econômicos - principalmente por sua proximidade com o estado de São Paulo -, se constituindo como um centro urbano de referência macro-regional ${ }^{1}$. Por fatores específicos, relativos ao seu desenvolvimento histórico singular, sua região vivenciou um dos maiores surtos demográficos já vistos no Brasil, tornando-se um dos pólos econômicos mais promissores do interior do país. Alicerçada inicialmente na cafeicultura, atualmente Londrina se destaca por seu setor agroindustrial e pelas atividades terciárias que lhe estão vinculadas.

Como uma cidade que em sua relativa jovialidade reuniu significativo contingente populacional, firmando-se rapidamente como importante núcleo urbano na atual divisão territorial do trabalho brasileira, Londrina cresceu e se desenvolveu de forma acelerada. Em apenas algumas décadas, passou da condição de "um pequeno amontoado de casas de madeira" para tornar-se - com certa dose de ufanismo de sua população e dos meios de comunicação locais - a "terceira maior do sul do Brasil", além de ter se constituído, em 1998, município sede da "primeira região metropolitana do interior do país". Dada a intensidade deste processo, desde a década de 1970 tem sido produzida uma vasta bibliografia sobre a cidade, que direta ou indiretamente trata de seu desenvolvimento sócio-espacial ${ }^{2}$.

De maneira geral, como indica esta bibliografia, o crescimento de Londrina pode ser apreendido com base em dois momentos marcantes da história econômica regional.

\footnotetext{
${ }^{1}$ A partir do estudo realizado por Nakagawara (1972) no início da década de 1970 sobre a área de influência de Londrina, é possível constatar que nessa época a cidade já se constituía como um centro urbano de referência macro-regional, influenciando, além da própria região norte-paranaense, o OestePaulista e parte do Mato Grosso do Sul.

2 Dentre estas pesquisas, destacam-se os trabalhos de Almeida (1981), "Participação dos Operários de Origem Rural em Área Urbana: Londrina - PR”; Barnabé (1989), “A Organização Espacial do Território e o Projeto da Cidade: o caso da Companhia de Terras Norte do Paraná"; Linardi (1995), "Pioneirismo e Modernidade: a urbanização de Londrina - PR"; Castelnou (2002), "Arquitetura Londrinense: expressões de intenção pioneira"; Grassioto \& Grassioto (2003), "A Atividade Comercial e sua Relação com o Urbano: o exemplo de Londrina"; Fresca (2002), "Mudanças Recentes na Expansão Físico-Territorial de Londrina"; (2004) "A Rede Urbana do Norte do Paraná"; Januzzi (2005), "O Desenvolvimento de Londrina e as Transformações nos Espaços Públicos da Região Central”; e Oura (2006), "Verticalização em Londrina - Paraná (1950 - 2005): a produção do espaço urbano e seu desenvolvimento pelos edifícios verticais".
} 
Durante as três primeiras décadas da cidade, quando vigorou a expansão da cafeicultura no Norte do Paraná, seu desenvolvimento sócio-espacial esteve associado, principalmente, à chegada do "progresso" a uma extensa área de fronteira agrícola, praticamente desocupada e que subitamente passou a ser representada como "a terra da promissão". Em decorrência destas representações, este período se caracterizou, especialmente, pelo rápido adensamento do núcleo histórico central, onde até a década de 1960 concentrou-se quase que a totalidade dos serviços do município, e pela configuração de uma paisagem urbana peculiar para o contexto de um centro urbano tão recente. Pois, antes mesmo de completar trinta anos, Londrina contava aproximadamente 135.000 habitantes e sua área central já possuía alguns edifícios de cunho modernista, construídos em pleno compasso com as tendências estéticas das grandes cidades brasileiras da época. No contexto de uma fronteira agrícola recém aberta, tais edificações surgiram, sobretudo, para ostentar o dinamismo econômico e o rápido progresso atingido pela então "capital mundial do café”.

No entanto, a partir de 1960, com o declínio da cafeicultura e o conseqüente êxodo rural em toda a região norte paranaense, findaram-se os "anos dourados" e Londrina industrializou-se, sofrendo um inchaço significativo. Como destacam as pesquisas, se até então o crescimento da cidade era percebido, principalmente, pelas rápidas transformações na paisagem de seu núcleo central, desde esta década sua malha urbana passou a se expandir de maneira expressiva. Enquanto ao norte e ao extremo sul do núcleo histórico proliferaram-se, cada vez mais, os conjuntos habitacionais e os assentamentos urbanos irregulares, nos quadrantes sul e sudoeste ergueram-se luxuosos edifícios e equipamentos urbanos voltados ao futuro terciário do município. Especialmente nas últimas duas décadas esta tendência de expansão tornou-se ainda mais evidente com a construção do Shopping Center Catuaí na zona sul-sudoeste e com o surgimento de certos "eixos de desdobramento" 3 (SPÓSITO, 1991) da área central nesta direção, como as avenidas Higienópolis e Madre Leônia Milito.

\footnotetext{
${ }^{3}$ Em suas reflexões acerca do centro urbano e das formas de expressão da centralidade, Spósito (1991) afirma que, ao contrário das "áreas de expansão" e dos "subcentros", os "eixos de desdobramento" caracterizam-se, especialmente, pela localização de atividades tipicamente centrais, mas de forma especializada. Nestes eixos não se reproduzem a alocação da totalidade das atividades das áreas centrais, mas apenas de algumas delas. Segundo a autora, o nível de especialização destes "eixos de desdobramento" da área central é quase sempre funcional e/ou sócio-econômico, se traduzindo na procura dos segmentos de maior poder aquisitivo do mercado, que progressivamente abandonam o comércio e os serviços das áreas centrais como uma forma de distinção.
} 
Para autores de estudos mais recentes, Londrina passa atualmente por um processo de "metropolização", que inaugura uma nova fase de seu desenvolvimento urbano. Tendo em vista as diretrizes que o precederam, esse processo normalmente é interpretado tanto pelo grande volume de investimentos realizados em alguns pontos da cidade, garantindo sua consolidação enquanto pólo econômico, turístico, científico e artístico do interior do país, como por seus aspectos "desagregadores", em decorrência das disparidades sociais que atualmente caracterizam os grandes centros urbanos brasileiros. Ainda que do ponto de vista teórico a metropolização de Londrina não seja consensual, a representação "Londrina Metrópole" é constantemente veiculada pela mídia local ${ }^{4}$, assim como tem sido compartilhada por grande parte de sua população. Metrópole ou não, o fato é que a cidade passa atualmente por uma nítida mudança de escala, perceptível pelo surgimento de novos focos de verticalização e de novas centralidades, pela contínua expansão de áreas periféricas, assim como pelo nascimento de vários enclaves exclusivos, voltados à moradia, ao comércio e ao lazer.

A bibliografia na qual se dão estes apontamentos iniciais é composta por pesquisas realizadas em diversas áreas acadêmicas - como História, Sociologia, Geografia, Arquitetura e Urbanismo - que embora assinalem tendências importantes do desenvolvimento sócio-espacial de Londrina, notadamente o fazem quase que exclusivamente a partir de duas perspectivas distintas, mas que chegam a conclusões semelhantes. Primeiramente, existem aquelas análises onde o processo é abordado mediante as transformações mais imediatas da paisagem urbana londrinense, e, por outro lado, há também os estudos que fundamentam seus diagnósticos em algumas variáveis quantitativas - como índices relativos à verticalização, industrialização e serviços do município, número e distribuição de equipamentos urbanos voltados à saúde, educação e segurança, etc. Em ambos os casos, as conclusões traçadas sob estas variáveis tendem a apontar para o fato de que o crescimento de Londrina tem sido marcado pela expansão irregular e socialmente desigual de sua malha urbana.

A visão de Castelnou, no plano da Arquitetura e do Urbanismo, sintetiza bem o tom destes diagnósticos, quando o autor aponta que:

\footnotetext{
${ }^{4}$ Como é possível perceber em um artigo veiculado no Jornal de Londrina no dia 05 de dezembro de 2004, dias antes do aniversário de 70 anos da cidade, onde sua autora escreve: " $E$ a pequena localidade de terra vermelha, distante do mar, se transformou em uma metrópole. Exatos 70 anos se passaram pequena história diante da existência da humanidade, mas grande e pujante exemplo de crescimento e prosperidade. Bem merecido aniversário devem comemorar os 480.000 habitantes de Londrina - hoje a terceira maior cidade do Sul do Brasil na próxima sexta-feira, dia 10 de dezembro". (KINDLEIN, 2004: 14. Grifo meu).
} 
Muitos fatores, entre os quais sua grande acessibilidade, continuidade urbana com municípios vizinhos e intensa migração pendular, vêm caracterizando a região londrinense como uma área pré-metropolitana, a qual, devido ao crescimento rápido e desordenado sofreu várias situações irregulares e de mau uso do solo urbano, incluindo o adensamento em pontos localizados ou a desintegração de algumas áreas - os chamados vazios urbanos -, o que poderia ter sido evitado em todo o processo de ocupação e estruturação de Londrina, caso houvesse ocorrido um planejamento mais eficaz. Isto se deu em especial devido às iniciativas que marcaram sua ocupação por influência do capital público e privado, responsável por transformações que beneficiaram determinadas parcelas da população, ou ainda certos grupos econômicos em detrimento de outros. (2002: 19. Grifos do autor).

Até o momento parecem inexistir pesquisas que abordem o crescimento de Londrina a partir de um viés antropológico e etnográfico, como me proponho no presente trabalho ${ }^{5}$. Pois, com base na concepção de "etnografia urbana" elaborada por Magnani $(2006,2007)$ - um autor que vem se ocupando da análise da cultura urbana nas grandes cidades -, acredito que seja possível traçar um diagnóstico pautado em dados mais qualitativos acerca das transformações sócio-espaciais na cidade. Afinal, para além das conclusões traçadas no plano quantitativo e no das análises fundamentadas no imediatismo da paisagem urbana, quais as implicações deste processo no cotidiano de sua população? E quais conclusões, ainda que provisórias, podem ser traçadas sobre a suposta metropolização de Londrina a partir das práticas, hábitos e costumes vivenciados em seu cotidiano? Para tentar responder a estas questões, compartilharei aqui da concepção de "etnografia" proposta por Magnani, onde esta se constitui enquanto:

[...] uma forma especial de operar em que o pesquisador entra em contato com o universo dos pesquisados e compartilha seu horizonte, não para permanecer lá ou para explicar ou interpretar a lógica de sua visão de mundo, mas para segui-los até onde seja possível e, numa relação de troca, contrastar as suas teorias com as deles e assim tentar sair com um modelo novo de entendimento, ou, ao menos, com uma pista nova, não prevista anteriormente. (MAGNANI, 2007: 04. Grifos do autor).

\footnotetext{
${ }^{5}$ Mediante o levantamento bibliográfico realizado nos arquivos da Universidade de São Paulo e da Universidade Estadual de Londrina, as únicas exceções a este quadro referem-se às pesquisas etnográficas desenvolvidas por Maia (2005) e por Almeida \& Adum (2007), em espaços como a Avenida Higienópolis, que liga o centro à zona sul da cidade, e o Bosque Mal. Cândido Rondon, respectivamente. Ainda assim, estas pesquisas, realizadas sob a problemática do patrimônio cultural, abordam o processo de crescimento da cidade apenas de maneira indireta.
} 
Sabe-se, no entanto, que a etnografia, como método característico da Antropologia ${ }^{6}$, foi forjada em uma época em que a disciplina se ocupava quase que exclusivamente do estudo de sociedades de pequena escala, tais quais os chamados "povos primitivos", cultural e geograficamente distantes do meio de origem do pesquisador, como uma tentativa de se apreender hábitos e costumes destas populações supostamente "exóticas". Entretanto, atualmente, em uma época que não restam dúvidas de que a Antropologia é uma ciência que se define pelo pressuposto da alteridade entre o pesquisador e os universos pesquisados, e não pela natureza de seu objeto - primitivo ou exótico -, sabe-se também que a etnografia pode ser aplicada no contexto das grandes cidades contemporâneas mantendo-se fiel ao legado teórico e metodológico dos primeiros tempos da disciplina.

Então, quando aplicada ao contexto urbano, a etnografia, ou a perspectiva "de perto e de dentro" - para utilizar o termo proposto por Magnani $(2006,2007)$-, caracteriza-se, especialmente, pela tentativa de se apreender a dinâmica urbana através de recortes espaciais bem delimitados e a partir dos próprios atores sociais, que "[...] por meio do uso vernacular da cidade (do espaço, dos equipamentos, instituições) nas esferas do trabalho, religiosidade, lazer, cultura, política, vida associativa, estratégias de sobrevivência, são os responsáveis por sua dinâmica cotidiana” (MAGNANI, 2007: 07).

Mas conforme a definição mais ampla de "etnografia" proposta pelo autor, deve se estar atento ao fato de que não se trata de apreender a dinâmica urbana a partir da concepção particularista do universo pesquisado - afinal, o pesquisador deve compartilhar de seu horizonte, mas não deve permanecer lá para explicar ou interpretar sua visão de mundo -, mas sim de articular esse olhar "de perto e de dentro" a uma lógica mais geral, fundamentada em princípios abrangentes e estruturas de mais longa duração. Trata-se, na realidade, de realizar um movimento característico da etnografia, que, segundo Geertz (1998), constitui-se como um "esforço intelectual” entre a busca pelo menor detalhe nos locais menores e a mais global das estruturas globais, de forma que ambos possam ser observados simultaneamente, e que quando transposto para o contexto urbano exprime-se na busca por uma Antropologia "da" cidade a partir de uma Antropologia realizada "na” cidade (MAGNANI, 2006, 2007).

\footnotetext{
${ }^{6}$ Compartilho aqui da concepção de Magnani (2007), que concebe a etnografia como um método próprio da Antropologia em "sentido amplo"; ou seja, que não se restringe enquanto uma técnica e que engloba também as estratégias de contato e inserção no campo de pesquisa como condições para a "experiência etnográfica", compartilhada entre o pesquisador e os universos pesquisados.
} 
No contexto das grandes cidades, o etnógrafo, então, confronta-se com a mesma realidade que os pesquisadores de outras áreas enfrentam em conjunturas mais amplas, porém, inserindo-se em contextos "menos nítidos" e "microscópicos", por assim dizer. E é exatamente por este fato que a etnografia proporciona uma contribuição específica para a compreensão da dinâmica urbana nas grandes cidades. Pois, sua forma de operar, atenta aos detalhes, lhe permite captar certos aspectos que normalmente passam despercebidos pelas análises "de fora e de longe", que enfatizam unicamente as variáveis macro e o grandes números.

Nas palavras de Magnani:

É evidente que não há como negar todos aqueles problemas apontados nos diagnósticos com base em inúmeros e consistentes estudos e comprovados também pela própria experiência do dia-a-dia nas grandes cidades, nem, evidentemente, as injunções dos interesses das grandes corporações transnacionais e das elites locais nos sistemas decisórios sobre o ordenamento urbano e sua influência nas condições de vida da população. Mas a pergunta que ainda paira é: isso é tudo? Este cenário degradado esgota o leque das experiências urbanas? Não seria possível chegar a outras conclusões, desvelar outros planos mudando este foco de análise, de longe e de fora, com base em outros métodos e instrumentos de pesquisa, como os da antropologia, por exemplo? [Neste sentido] [...] As grandes cidades certamente são importantes para análise e reflexão, não apenas porque integram o chamado sistema mundial e são decisivas no fluxo globalizado e na destinação dos capitais, mas também porque concentram serviços, oferecem oportunidades de trabalho, produzem comportamentos, determinam estilos de vida [...] toda essa diversidade leva a pensar [...] na possibilidade de sistemas de trocas de outra escala, com parceiros até então impensáveis, permitindo arranjos, iniciativas e experiências de diferentes matizes. (MAGNANI, 2006: N/p.).

Dadas estas considerações iniciais, este trabalho tem por objetivo apreender alguns aspectos do processo de crescimento de Londrina sob o viés da Antropologia Urbana e da etnografia, tomando como referência a análise de um equipamento urbano particular, que recentemente passou por uma situação específica. Trata-se do Bar Valentino, um dos espaços de sociabilidade noturna mais tradicionais de Londrina, que durante o ano de 2006 foi transferido do local onde funcionou por 27 anos, na região central, para um bairro relativamente nobre, em uma área de expansão recente entre o centro e as zonas sul-sudoeste da cidade. Mediante o prisma da etnografia, acredito que a transferência do Bar Valentino é capaz de refletir no âmbito "microscópico" do 
cotidiano alguns aspectos da mudança de escala experimentada atualmente por Londrina, que, para alguns autores, passa por um processo de metropolização.

Suponho que esta situação delineou-se como um contexto privilegiado, que me permitiu apreender certas tendências deste processo tanto no plano físico-espacial quanto no plano da sociabilidade. Especialmente no que se refere à sociabilidade, a idéia mais geral defendida aqui é que, se enquanto esteve localizado na região central, o cotidiano vivenciado pelos freqüentadores do Bar Valentino denotava certos costumes e padrões de interação social típicos de uma cidade média, fundada na realidade de um centro único, agora, em sua atual localização, este espaço exprime hábitos e comporta arranjos coletivos próprios de uma cidade descentralizada, que começa a ganhar contornos metropolitanos.

A noção de circuito elaborada por Magnani (2000,2005) mostrou-se como fundamental para a sustentação deste argumento. Para este autor, os circuitos referem-se a um conjunto de estabelecimentos, espaços e equipamentos urbanos caracterizados por determinadas práticas ou oferta de determinados serviços, sem que necessariamente estes estejam conectados na paisagem urbana por uma relação de contigüidade espacial. Como afirma Magnani, através desta categoria torna-se possível articular dois elementos fundamentais relativos à dinâmica de inserção dos atores e grupos sociais na paisagem urbana - ou seja, as próprias ações sociais, com os símbolos, sinais de pertencimento, preferências e valores as quais estão associadas, e os espaços, equipamentos e instituições, não na condição de meros cenários, mas como produtos de práticas sociais acumuladas e como fator de determinação para estas práticas. Então, a partir da etnografia dos circuitos torna-se possível abstrair regularidades nos deslocamentos de determinados atores sociais pela cidade, já que suas inserções nos espaços ocorrem de maneira lógica - e não aleatória -, associada às suas escolhas, preferências e possibilidades.

Em Londrina, assim como em qualquer cidade de seu porte, existem inúmeros equipamentos de lazer voltados à sociabilidade noturna - como bares, boates, casas de shows, cinemas e teatros, frequientados pelos mais diversos públicos - , tornando-se possível falar concretamente na existência de circuitos de lazer noturno. Visto que enquanto o Bar Valentino esteve localizado na área central de Londrina seu espaço se constituiu enquanto ponto de confluência entre alguns destes circuitos, sua mudança de endereço acabou por reconfigurar toda a lógica destes deslocamentos. Deste modo, a 
tese que defendo neste trabalho é de que a mudança do Bar Valentino, com as respectivas implicações na reconfiguração dos circuitos nos quais está envolvido, reflete, a partir de um caso particular, algumas tendências sócio-espaciais relativas à fase de expansão urbana pela qual Londrina passa atualmente. Afinal, se comparados ao contexto anterior, os padrões de interação social formados pelos freqüentadores do Bar Valentino em sua nova localização indicam circuitos de lazer noturno que têm sua lógica associada às preferências e possibilidades relativas a uma "cidade grande", fundada em múltiplas centralidades.

Portanto, este trabalho se consiste em uma análise etnográfica de cunho comparativo, entre o cotidiano vivenciado pelos freqüentadores do Bar Valentino em sua antiga e em sua atual localização, a fim de trazer à tona certos aspectos acerca do desenvolvimento sócio-espacial de Londrina, e de seu suposto processo de metropolização, que em grande parte têm sido excluídos das pesquisas realizadas "de fora e de longe". Pois, sob a perspectiva "de perto e de dentro", uma cidade em crescimento não se define apenas por dados quantitativos, pela incorporação de certas estruturas materiais em sua paisagem ou pela atuação de promotores imobiliários, mas também a partir da diversidade de experiências urbanas ali vividas cotidianamente, seja nas esferas do trabalho, da política, da economia, ou nas práticas de lazer de sua população.

Assim sendo, a presente etnografia se apresentará organizada em três capítulos, além das considerações finais. O primeiro deles - "Tendências no Desenvolvimento Sócio-Espacial de Londrina" - constitui-se como uma revisão acerca do processo de crescimento da cidade, com ênfase nos momentos mais marcantes de sua história urbana. Com base em parte da bibliografia já produzida sobre o processo de desenvolvimento sócio-espacial de Londrina, neste capítulo busco estabelecer um contexto sob o qual serão interpretados os dados etnográficos apresentados nos capítulos subseqüentes. No segundo capítulo, intitulado "O Bar Valentino no Centro", será traçada a história deste espaço desde o seu surgimento, em 1979, até sua mudança de endereço, em 2006, onde busco demonstrar como o Bar Valentino passou a ser incorporado por diferentes grupos sociais, além de como os padrões de interação e os circuitos de lazer estabelecidos por estes grupos estiveram associados às possibilidades dadas por uma cidade média, fundada em um centro único. Finalmente, no terceiro capítulo, "O Novo Bar Valentino", serão expostos e analisados alguns dados 
etnográficos relativos ao processo de transferência do Bar Valentino e às formas com que este espaço passou a ser apropriado por seus freqüentadores em sua atual localização.

Além da bibliografia específica sobre o desenvolvimento sócio-espacial de Londrina e de algumas obras relativas ao que se poderia chamar de "estudos urbanos", as demais fontes utilizadas nesta pesquisa constituem-se como um conjunto formado por entrevistas em profundidade e conversas informais realizadas com os atuais e os exproprietários do Bar Valentino, com alguns de seus funcionários, ex-funcionários e freqüentadores; pelas notas tomadas no caderno de campo durante os períodos de observação participante; por artigos e crônicas veiculadas na mídia local, que de alguma forma remetem ao Bar Valentino ou ao processo de crescimento da cidade; por postagens encontradas em blogs e no site de relacionamentos "orkut.com"; assim como por algumas fotografias e mapas - editados a partir do site "google.maps" - , a fim de ilustrar certas informações e argumentos presentes ao longo do texto. Especialmente no que se refere às entrevistas em profundidade, cabe frisar que em meio à heterogeneidade e à rotatividade dos freqüentadores do Bar Valentino, a pesquisa priorizou a análise dos depoimentos concedidos por aqueles usuários do bar que já o freqüentavam anteriormente à sua transferência de endereço; pois acredito que, apesar desta limitação, a ênfase neste grupo me permitiu estabelecer parâmetros satisfatórios para os objetivos aqui propostos.

Estas fontes foram reunidas em dois momentos distintos: entre meados de 2004 e o final de 2005, quando realizei uma pesquisa de Iniciação Científica no espaço do Bar Valentino durante minha graduação em Ciências Sociais pela Universidade Estadual de Londrina, e entre 2006 e 2008, período em que desenvolvi esta pesquisa vinculado ao Programa de Pós-Graduação em Antropologia Social da Universidade de São Paulo (PPGAS - USP). 


\section{TENDÊNCIAS NO DESENVOLVIMENTO SÓCIO-ESPACIAL DE LONDRINA}

Com a apresentação deste capítulo tenho por objetivo estabelecer uma revisão acerca do desenvolvimento sócio-espacial de Londrina. Mediante este procedimento busco esclarecer as causas e circunstâncias das sucessivas transformações na malha urbana londrinense, que culminaram nas feições que a cidade possui atualmente. Afinal, se a tese defendida aqui é a de que o a transferência do Bar Valentino reflete a atual mudança de escala experimentada por Londrina - ou, como defendem alguns autores a sua metropolização -, primeiramente, é necessário buscar a forma sob a qual se deu este

processo. Pois, apenas sob este contexto torna-se possível transitar entre uma Antropologia "na" cidade e uma Antropologia "da" cidade nos capítulos posteriores.

\subsection{A Ocupação do Norte Paranaense e a Atuação da Companhia de Terras Norte do Paraná}

A ocupação do território norte paranaense iniciou-se no final do século XIX, a partir do deslocamento de fazendeiros paulistas e mineiros em busca de novas terras para o plantio de café. No momento da chegada dos primeiros pioneiros à região, as áreas tradicionalmente cafeicultoras dos estados de Minas Gerais e, sobretudo, de São Paulo, passavam por um processo de esgotamento de seus solos, enquanto as terras norte paranaenses recém descobertas, revelavam-se muito férteis e com preços bastante acessíveis, já que se tratava de uma área praticamente virgem e desocupada. Sob este contexto, o Norte do Paraná rapidamente passou a ser ocupado como uma expansão da fronteira agrícola paulista; um processo que perdurou por mais de meio século e deu contornos característicos as suas cidades.

Os primeiros fazendeiros a chegarem ao Norte do Paraná ocuparam a região do chamado "Norte Pioneiro" - uma área compreendida entre os rios Paranapanema, Itararé e Tibagi, próxima à fronteira com o estado de São Paulo. Esta região foi ocupada inicialmente por proprietários rurais relativamente isolados, que realizavam, seus empreendimentos de maneira individual e formavam suas grandes fazendas aos moldes 
tradicionais de seus estados de origem. Contudo, pelos rápidos rendimentos que a cafeicultura trazia aos que ali se aventuravam, o fluxo populacional rumo à região logo aumentou, implicando no surgimento de uma série de cidades que compartilham de características comuns - como Tomazina, Santo Antônio da Platina, Jacarezinho, Cambará, Bandeirantes e Cornélio Procópio.

Em primeiro lugar, a fundação destas cidades pioneiras mostra-se vinculada à chegada dos grandes proprietários rurais que cediam parte de suas terras ao futuro núcleo urbano, onde, via de regra, construía-se uma capela e uma praça, no entorno das quais passava a se fixar a população (FRESCA, 2004). Como observa Cesário (1991), dada a vinculação destes centros urbanos às grandes propriedades fundiárias, correspondia às próprias fazendas a função de organizar suas produções agrícolas, culminando na formação de cidades carentes de uma estrutura administrativa e de serviços ${ }^{7}$. Além disso, essas cidades do chamado Norte Pioneiro, por terem surgido em conseqüência de iniciativas particulares e, até certo ponto, esparsas, deram ao povoamento da região um caráter tipicamente desordenado e irregular.

Visando legalizar e sistematizar a ocupação da região norte paranaense, que revelava espantosa produtividade e grande potencial agrícola, a partir de 1920 o governo estadual passou a criar políticas de apoio e fornecimento de terras em favor de empresas particulares de colonização. Tal estímulo à colonização dirigida fundamentouse, sobretudo, na precariedade econômica do Paraná - que nos primeiros anos do século XX, à exceção da região sul, tinha praticamente todo o seu território ainda desvinculado da economia nacional -, inviabilizando qualquer empreendimento infra-estrutural ou projeto que pudesse promover, a partir do Estado, a ocupação de áreas extensas. Este movimento, marcado pelo surgimento de iniciativas de colonização e fundação de cidades a partir da concessão de terras, inaugurou uma nova etapa de ocupação do território norte paranaense.

No período entre 1930 e 1945, na área compreendida entre os rios Paranapanema, Tibagi, Ivaí e o município de Manoel Ribas, efetivou-se a ocupação do chamado "Norte Central" do Paraná, que tem Londrina, Maringá, Arapongas,

\footnotetext{
${ }^{7}$ Como afirma Cesário (1991), é, principalmente, por este fato que, apesar de apresentarem condições naturais propícias às atividades agrícolas, nenhum destes núcleos urbanos do "Norte Pioneiro" possui atualmente a mesma importância de que hoje desfrutam as maiores cidades paranaenses. Contrariamente, as cidades do chamado "Norte Novo", com destaque para Londrina e Maringá, destacam-se por um setor terciário muito desenvolvido, sobretudo, em decorrência de sua forma particular de ocupação, que priorizava uma plena integração entre o meio rural e o urbano.
} 
Apucarana e Ivaiporã como seus principais núcleos urbanos. Contrariamente ao ocorrido na região pioneira, no Norte Central a gênese das cidades não esteve vinculada às grandes fazendas e aos seus proprietários, mas aos concessionários, que previamente criavam as plantas urbanas dividindo-as em pequenas datas. Nesta região, os núcleos de povoamento também foram planejados visando tanto o assentamento dos produtores rurais quanto à formação de cidades, que deveriam desenvolver uma estrutura de serviços urbanos necessários ao campo.

O loteamento desta área foi todo planejado de forma que cada cidade estivesse posicionada para atender às exigências de sua população e do mercado consumidor, obedecendo a critérios rigorosos quanto às suas localizações. De maneira geral, o que difere o Norte Central do Paraná em relação ao Norte Pioneiro foi o caráter induzido de sua ocupação, já que as empresas colonizadoras definiam previamente as diretrizes que deveriam nortear o processo de povoamento. Dentre estes empreendimentos particulares de colonização, o da Companhia de Terras Norte do Paraná (CTNP), com origem no capital inglês, é apontado como o mais notável, constituindo-se como marco referencial de toda a ocupação do norte paranaense.

O surgimento da CTNP esteve vinculado a um contexto onde os países europeus experimentavam uma grave crise econômica decorrente do Pós-I Guerra Mundial (1914 - 1918), impossibilitando-os de realizar grandes investimentos no exterior. No entanto, neste momento o governo brasileiro havia contraído uma grande dívida para com a Inglaterra - que na época era de 102.623.294 libras (STECA \& FLORES, 2002) -, dando margem para que este país realizasse investimentos em projetos de colonização no Brasil. Dada esta situação, em 1924 chegou ao país um grupo de consultores britânicos, sob o título de "Missão Montagu", cujo objetivo era avaliar as melhores possibilidades para a aquisição de terras brasileiras pelo capital inglês.

A partir dessa missão econômica, chefiada por Simon Joseph Fraser, também conhecido como Lord Lovat, um especialista em agricultura e assuntos florestais, foi adquirida uma faixa de 1.235.240 hectares (ALMEIDA, 1997) no Norte do Paraná. Imediatamente foi fundada a "Brazil Plantations Ltd.", com sede em Londres, para coordenar o plantio de algodão nestas terras, que a partir de então abasteceriam parte da indústria têxtil inglesa. Contudo, pela falta de sementes sadias no mercado, o projeto original da Brazil Plantations não obteve êxito, e, como alternativa, criou-se a firma "Paraná Plantations Company" para a realização de um empreendimento imobiliário no 
território adquirido ${ }^{8}$. Para que o novo projeto se concretizasse era necessário, então, que toda a região fosse dotada de infra-estrutura em termos de meios de comunicação e transportes. Assim, a Paraná Plantations Company subdividiu-se em duas subsidiárias brasileiras: a "Companhia de Terras Norte do Paraná”, que se ocupou da colonização, e a "Companhia Ferroviária São Paulo-Paraná", que com a compra do ramal ferroviário estendeu seus trilhos até a zona de loteamento.

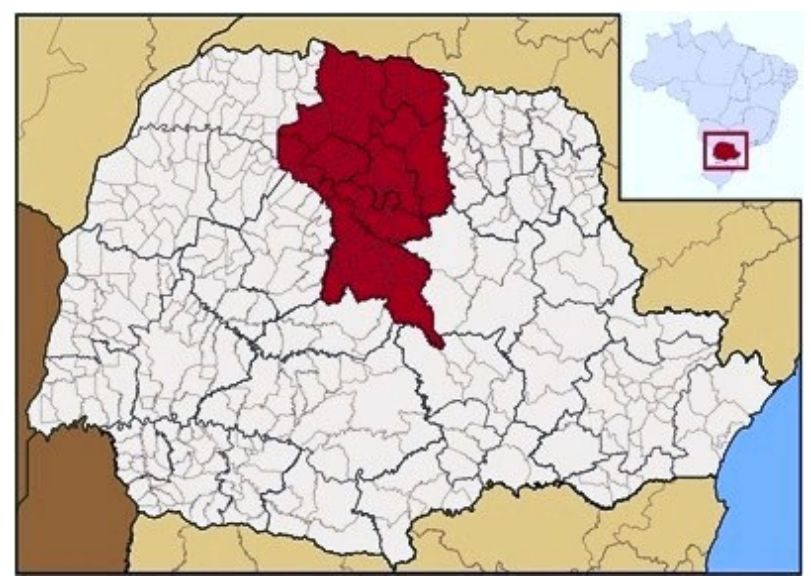

Mapa 1. Mesorregião do "Norte Central" do Paraná. Fonte: www.wikipedia.org.br

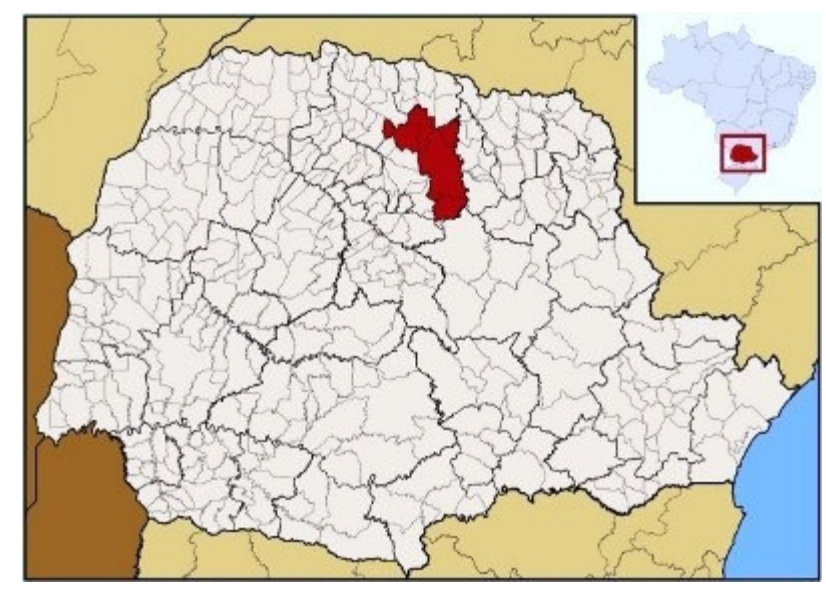

Mapa 2. Microrregião de Londrina. Fonte: www.wikipedia.org.br

\footnotetext{
${ }^{8}$ Segundo Steca \& Flores (2002), o termo "plantation" com que foram nomeadas as firmas "Brazil Plantations Company" e a subseqüente "Paraná Plantations Company" possuem conotações distintas. Enquanto que para a primeira o termo significava latifúndios produtores de algodão, ao molde das fazendas do sul dos Estados Unidos, para a segunda, desde o seu início, o termo remetia à colonização, pressupondo a consciência de um futuro projeto de povoamento.
} 
O projeto de ocupação espacial da CTNP era particular e original no contexto brasileiro. O loteamento da região iniciou-se em 1933, com a divisão do extenso território em zonas de ocupação. Estas, por sua vez, foram divididas em glebas, reservadas para a localização de patrimônios e cidades. Enquanto os patrimônios e as pequenas cidades, distantes cerca de 15 a 19 Km. entre si, funcionariam como pólos de apoio às propriedades rurais, as cidades maiores, planejadas como pólos regionais, seriam distribuídas hierarquicamente, a uma distância média de $100 \mathrm{Km}$., ao longo de um eixo viário principal. Esta distribuição obedeceria à seguinte ordem: Londrina (1929), Maringá (1942), Cianorte (1953) e Umuarama (1955); cidades que, além de sedes jurídico-administrativas, exerceriam a função de concentrar o comércio e os serviços mais sofisticados para a região.

Especialmente a cidade de Londrina, a primeira fundada pela Companhia em 1929, ocupou uma posição importante neste projeto de colonização. Pois, além de a cidade ter sido previamente planejada para ser a sede do empreendimento, como base urbana de suporte para o desempenho técnico e administrativo, Londrina também se tornou o principal núcleo intermediário de distribuição e comercialização de produtos agrícolas e industrializados entre todo o Norte do Paraná e o estado de São Paulo. Como centro irradiador deste processo, quando foi elevada à condição de município em 1934, Londrina já contava com uma estrutura de serviços em crescimento para atender a uma demanda regional.

Quanto ao complexo sistema viário implantado pela CTNP, este se caracterizava por uma ligação ferroviária da região norte paranaense com a "Estrada de Ferro Sorocabana", além de uma rodovia principal de acesso ao estado de São Paulo, visando facilitar a chegada dos migrantes e o escoamento da produção. Além disso, estradas secundárias garantiriam uma integração efetiva entre as pequenas propriedades rurais, os patrimônios e as cidades pólos regionais. Observa-se então, que a extensa área colonizada pela CTNP, assim o foi mediante um planejamento racional, que visava não apenas garantir a integração entre o meio rural e o meio urbano, como também a ligação da região ao centro dinâmico da economia brasileira.

Como destaca Almeida: 
A CTNP estabeleceu uma completa rede de comunicações e de prestação de serviços necessária à produção e à comercialização agrícola [...] bem como uma estrutura de oferta de bens de consumo para servir às necessidades das populações rural e urbana. [...] Esse cuidadoso planejamento foi seguido em toda área colonizada pela CTNP, o que garantiu a ocupação das propriedades rurais concomitantemente ao surgimento das cidades e patrimônios. [...] De acordo com as diretrizes gerais do projeto, a colonização deveria viabilizar relações estreitas entre campo e cidades, permitindo o escoamento da produção agrícola, e uma estrutura adequada de atendimento à população migrante que chegava à região. (1997: 94 98).

Além do investimento em infra-estrutura, a CTNP também utilizava uma intensa propaganda em sua política de ocupação das terras no Norte do Paraná. Tanto a propaganda feita no Brasil, como a realizada no exterior, enfatizava a existência de uma região nova, que oferecia oportunidades de enriquecimento por suas terras férteis, além de suas condições climáticas e hidrográficas favoráveis às atividades agrícolas. Destacava-se também a facilidade na compra dos lotes rurais mediante o parcelamento no pagamento das terras adquiridas, bem como os subsídios oferecidos pela Companhia para as viagens e alojamento dos migrantes. Assim, a CTNP difundiu uma imagem da região como a "terra da promissão", o "novo eldorado" (ARIAS NETO, 1993; ALMEIDA, 1997). Um cartaz de divulgação da CTNP da década de 1930 ilustra isso com os seguintes dizeres:

CONSTRUA SEU LAR EM ZONA PROGRESSITA! Ja é quasi proverbial a riquesa e fertilidade das terras roxas apuradas, pertencentes á COMPANHIA DE TERRAS NORTE DO PARANÁ', onde existem em grande abundancia os melhores padroes de terra como comprovam a Figueira Branca, Jangada, Palmito, Jaborandy, Cambará de meia légua, Urtiga e outros, alem de madeiras de lei como sejam Peroba, Cedro, Canjarana, Pau Marfim e outras. Essa Zona Privilegiada pela natureza é dotada de clima inegualavel e saluberrimo. Para as terras desta Companhia tem immigrado grande numero de familias, as quaes confiadas na fertlidade dessas terras e no progresso ininterrupto da COMP. FERROVIÁRIA S. PAULOPARANÁ', em infatigavel collaboração com esta Comp. lá estao formando centenas de sitios e colonias, convictas na prodigalidade e dos lucros compensadores que irão usufruir fucturamente (Sic) (Grifos no original. Fonte: Acervo do Museu Histórico de Londrina). 
A ocupação do Norte Central do Paraná também está associada ao contexto político e econômico vivido no Brasil durante a década de 1930. É importante observar que quando se iniciou mais efetivamente a ocupação da região, o Brasil, sob o Governo Vargas (1930 - 1945), experimentava um processo de industrialização, sobretudo, através do estado de São Paulo. Em decorrência deste processo, enquanto o estado de São Paulo passava por uma intensa urbanização também foi implantada pelo governo federal uma política favorável à ocupação de novas áreas de fronteira agrícola; pois, gradativamente aumentava a demanda por matérias-primas e gêneros alimentícios para o abastecimento das indústrias e cidades paulistas. Além disso, nestas novas áreas de fronteira, como era o caso do Norte Central do Paraná, o Estado passou a incentivar uma agricultura, principalmente a do café, que se voltasse para as exportações. Afinal, os lucros advindos destas atividades seriam canalizados, via retenção de impostos, para atender aos processos de industrialização e urbanização do centro hegemônico do país.

Assim, mesmo com uma conjuntura desfavorável à economia cafeeira na época por conta de uma superprodução nacional e por uma recessão mundial decorrente da Crise de 1929, as políticas de incentivo estatais e o planejamento exercido pela CTNP mostraram-se eficientes o suficiente para garantir um crescimento econômico e demográfico surpreendente em todo o território norte paranaense. A partir de 1930, nas terras da Companhia, já dotadas de toda uma infra-estrutura necessária à sua ocupação, chegavam paulistas, mineiros e migrantes vindos de outras regiões do país, principalmente do Nordeste, além de estrangeiros, como japoneses, italianos e alemães - todos eles atraídos pelas possibilidades de tornarem-se proprietários rurais, ainda que em uma região distante. Como observam Steca \& Flores (2002), em apenas 25 anos surgiram 110 núcleos urbanos no Norte Central do Paraná, sendo que destes 62 foram criados pela CTNP e 48 por outros grupos, organizados ou não. Ainda, em três décadas o Norte do Paraná passou a ser a principal fonte de renda do estado, com sua população representando quase a metade do total de paranaenses, com um índice de $48 \%$. (ALMEIDA, 1981, 1997). Este crescimento em território norte paranaense perdurou até 1960, quando se esgotou a fronteira agrícola na região.

Em 1944, a CTNP foi vendida a um grupo de empresários paulistas que, a partir de 1951, a renomeou como "Companhia de Melhoramentos Norte do Paraná" (CMNP). Esta nova companhia foi responsável pela colonização do chamado "Noroeste do Paraná”, na região do Vale do Rio Ivaí, compreendendo as cidades de Cianorte, 
Umuarama, Paranavaí e Campo Mourão como seus principais núcleos urbanos. Em linhas gerais a CMNP adotou os mesmos procedimentos de sua antecessora, à exceção nas pequenas variações nas plantas urbanas, que predominantemente concebidas na forma de "tabuleiro de xadrez", como planos reticulados, passaram a apresentar formas elípticas ou em trevo. As cidades de Cianorte e Umuarama, ambas da década de 1950, como as principais surgidas a partir da empresa, foram planejadas para tornarem-se centros urbanos importantes, a exemplo de Londrina e Maringá no Norte Central do estado. Segundo Fresca (2004), é somente a partir da colonização do Noroeste do Paraná que efetivamente se constitui uma "rede urbana norte paranaense", cujas principais características são a proximidade entre seus núcleos urbanos, a diversidade de suas funções administrativas e sua vinculação à metrópole paulistana. Entretanto, foi através da atuação direta da Companhia de Terras Norte do Paraná que foram lançadas as bases de ocupação, tanto urbana como rural, de toda a região norte paranaense.

\subsection{Configurações Iniciais da Paisagem Urbana Londrinense}

Ao mesmo passo em que a Companhia de Terras Norte do Paraná iniciou o trabalho de demarcação das terras, divisão das glebas e construção das primeiras estradas de acesso à região do Norte Central paranaense, iniciou-se também a história do núcleo urbano de Londrina. Como parte integrante do empreendimento da CTNP, era fundamental ao loteamento rural a presença de um núcleo urbano que garantisse condições mínimas aos proprietários rurais em termos de coleta, beneficiamento e transporte da produção, além da oferta de bens e serviços de atendimento às demandas básicas da população; para assegurar tais condições foi criada, em 1929, a cidade de Londrina.

A planta urbana de Londrina teve seu arranjo inicial elaborado pelo engenheiro da CTNP, Alexandre Rasgulaeff. Em seu traçado original fora prevista uma população de aproximadamente 25.000 habitantes, com apenas um terço desse contingente localizado na área urbana e o restante na zona rural. Suas ruas, em ângulo reto, algumas paralelas e outras perpendiculares à via férrea e à rodovia, se estenderiam por cerca de 250 quadras. Enquanto nos bairros se instalariam os serviços comuns, como escolas, 
lojas comerciais, parques, além das residências, a área mais central da cidade seria destinada aos escritórios, serviços mais especializados e órgãos administrativos.

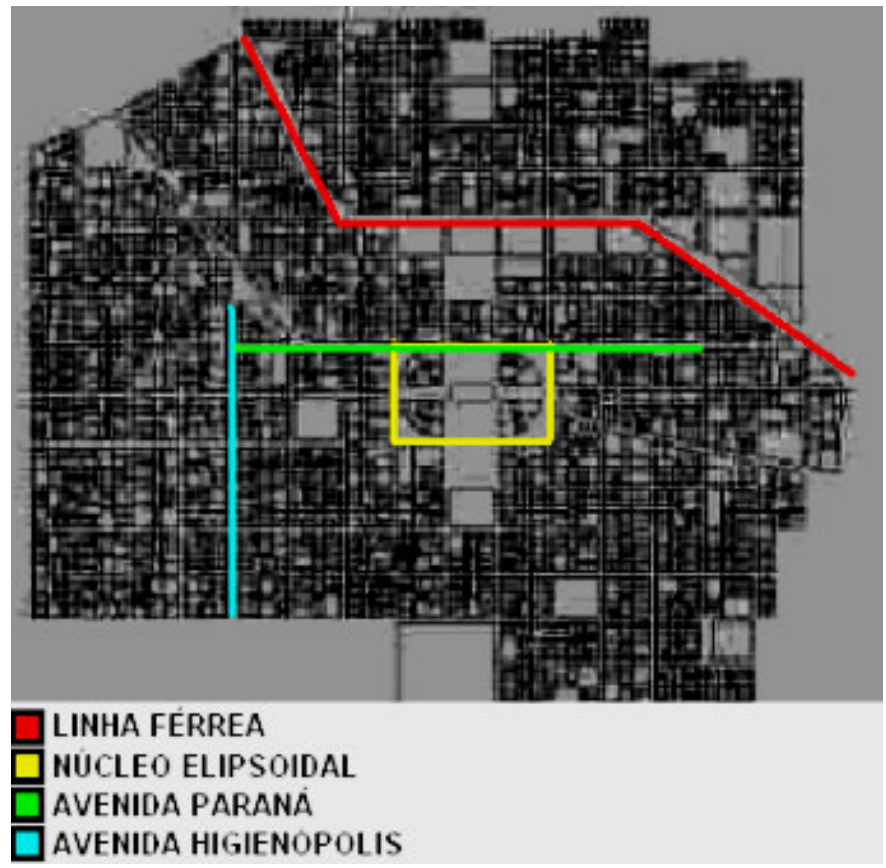

Mapa 3. Londrina (1938). Quadrilátero central inicial. Fonte: Oura (2006); editado pelo autor.

O núcleo do plano reticulado foi projetado em um formato elipsoidal a partir das praças Willie Davids, Primeiro de Maio, Gabriel Martins e Sete de Setembro. Dentre estas, na década de 1930, a Praça Willie Davids era a principal referência da cidade por nela situarem-se as associações comerciais, a prefeitura municipal e o escritório da CTNP - todos construídos em madeira nativa. Além disso, nas proximidades da estrada de ferro fora planejada também uma área destinada à implantação de futuras indústrias. Como observa Castelnou (2002), a partir desse plano urbanístico, Londrina apresentava um traçado típico, caracterizado pela regularidade, com um núcleo nítido e contornos muito bem definidos, contrariamente à maioria das cidades brasileiras tradicionais, geralmente de ocupação espontânea e irregular.

Após a elevação de Londrina à condição de município, em 1934, e da chegada da ferrovia, em 1935, a cidade rapidamente passou a ser ocupada. Na prática, tornou-se possível observar as primeiras evidências de segregação urbana a partir do projeto urbanístico elaborado pela CTNP. Pois, quando os primeiros lotes da cidade foram 
vendidos, fora estabelecida também uma distinção de valores, gerando, consequentemente, diferentes formas de uso e padrões do solo urbano com feições de um primeiro zoneamento. Na medida em que os lotes que envolviam a cidade eram muito mais baratos que os do núcleo central, fora registrado, já em 1936, o surgimento das primeiras vilas, que tendencialmente surgiam ao norte e ao leste do plano reticulado ${ }^{9}$. O próprio leito ferroviário se estabelecia como um marco para a ocupação seletiva da malha urbana: enquanto ao norte da linha férrea instalavam-se as camadas mais populares, o sul e sudoeste, como áreas mais propícias à expansão, devido à suavidade topográfica e à proximidade do centro, eram ocupados pelos que possuíam mais posses ${ }^{10}$.

Já contando com numeroso mercado consumidor rural e urbano, além de uma expressiva produção mercantil, em meados da década de 1940, quando a cidade completava pouco mais de uma década como sede municipal, a expansão urbana de Londrina já ultrapassava os limites definidos pelo projeto original da CTNP. Tal expansão fora marcada pelo surgimento de novas vilas, que, por não obedecer a nenhuma técnica urbanística, iam se constituindo de maneira irregular e desordenada. Já na área central, proliferavam-se os estabelecimentos comerciais, sobretudo, com a instalação de atacadistas de gêneros alimentícios e de armarinhos, filiais de empresas paulistas, que vendiam seus produtos para viajantes e demais moradores da cidade. A paisagem do centro de Londrina denunciava mais que um crescimento espacial e demográfico. Seus equipamentos urbanos, em conjunto, traduziam também uma ampliação do mercado de trabalho por conta dos serviços e comércios complementares às atividades agrícolas, além do aumento quanto à função administrativa e financeira da cidade - afinal, era em Londrina que se comercializava todo o excedente agrário da região.

\footnotetext{
${ }^{9}$ A partir dos primeiros registros acerca da população de menor poder aquisitivo sendo obrigada a residir em áreas desprivilegiadas, ou até mesmo "fora da cidade", torna-se possível questionar as falas a respeito da grande eficiência social do projeto da CTNP. Estas representações acerca do projeto urbanístico da CTNP possuem, ainda hoje, uma conotação positiva no imaginário londrinense, sobretudo, por fundar-se na idéia de que a cidade surgiu a partir da "igualdade de oportunidades". O zoneamento que se tinha na época, embora relativamente espontâneo, foi, portanto, indiretamente orientado pela CTNP, deixando evidente a complexidade das relações sociais envolvidas neste grande projeto fundiário.

${ }^{10}$ De maneira geral, ao sul e sudoeste da linha férrea residiam a alta e média burguesia, sendo que a primeira era composta pelos responsáveis pelo empreendimento imobiliário, além de fazendeiros e banqueiros, enquanto a segunda compunha-se de comerciantes locais e regionais, profissionais liberais e pequenos proprietários de terras. Já ao norte do leito ferroviário, residia um estrato social mais popular, formado predominantemente por trabalhadores rurais, peões, volantes da agricultura, empreiteiros, corretores e camelôs (CASTELNOU, 2002).
} 
Na época, a Avenida Paraná, tangencial ao núcleo elipsoidal, constituía-se como o centro nervoso de Londrina. Como principal artéria da vida urbana, esta avenida tinha em seu trecho entre a Avenida Rio de Janeiro e a Rua Professor João Cândido a grande concentração de endereços importantes na cidade; ali ocorriam os grandes desfiles escolares e os comícios políticos. Outro endereço importante na época era a Avenida Higienópolis, que cortava a cidade do centro para sul, até o Parque Guanabara. Seu traçado básico foi idealizado por Arthur Thomas, diretor da CTNP, inspirado no bairro aristocrático de Higienópolis, na capital paulista. Como resultado do boom cafeeiro, esta via, reservada à elite pelo alto preço de seus lotes, foi se definindo pelas residências em alvenaria, já que nela não eram permitidas as construções em madeira, características à cidade na época. Os palacetes em alvenaria que se erguiam na avenida remetiam às mansões da Avenida Paulista, em São Paulo, expressando os ideais de poder e ostentação da alta burguesia cafeeira, que reproduzia em Londrina a herança cultural de sua região de origem. Como tentativa de transposição de um estilo de vida da burguesia paulistana, a Avenida Higienópolis, com suas construções ecléticas, de inspirações neoclássicas ${ }^{11}$, revelava, já na década de 1940, o aburguesamento da vida citadina em pleno Norte do Paraná.

Ainda que na década de 1940 as construções em madeira, amplamente empregadas na década anterior, predominassem na paisagem urbana da cidade, o surgimento dos casarões e sobrados em alvenaria significava a exigência pela especialização e qualificação na produção das construções locais. Mediante a atuação de construtoras com sede na capital paulista, que atuavam sob técnicas e materiais amplamente difundidos nos grandes centros urbanos do país, o padrão de qualidade destas construções chama a atenção pelo fato de que o município de Londrina existia apenas há pouco mais de uma década. Estas edificações remetiam não apenas à afirmação de uma sociedade emergente e de Londrina como pólo regional, mas também a uma cidade que, embora estivesse inserida na realidade característica de uma fronteira agrícola, definia elementos de sua paisagem urbana em pleno compasso com as tendências estéticas da época.

${ }^{11}$ De acordo com Castelnou (2002), o neoclassicismo foi a corrente artística surgida no final do século XVIII e início do XIX, que expressava os interesses, hábitos e mentalidade da burguesia que assumira a direção da sociedade européia com a Revolução Francesa. Embora iniciado na Itália, fora na França que o neoclassicismo teve sua maior expressão. No Brasil, a partir da Independência, em 1822, o movimento neoclássico tornou-se o estilo oficial do Império, e, esteve sempre associado ao status, erudição e poder econômico. 


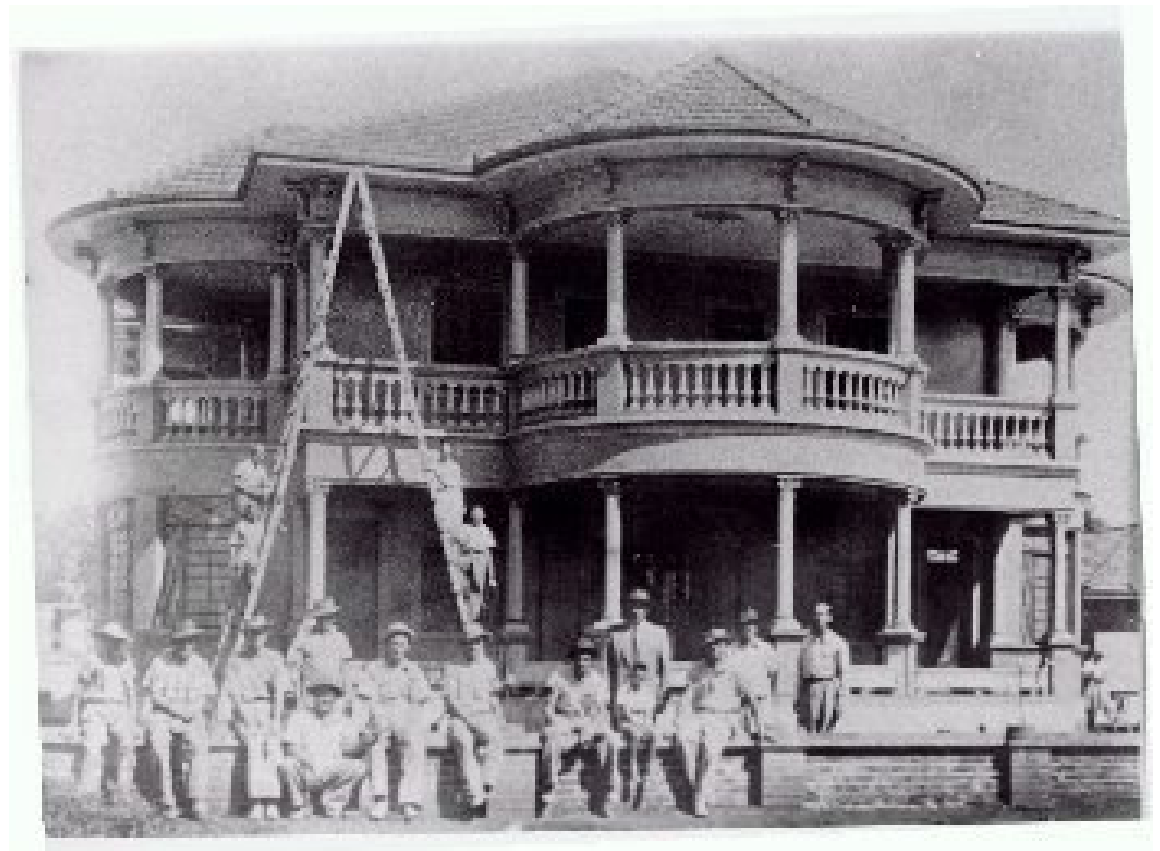

Foto 1. Construção da mansão "Celso Garcia Cid" (1947), na Avenida Higienópolis. Primeira obra em alvenaria com citações neoclássicas de Londrina.

Fonte: Instituto de Preservação do Acervo Cultural de Londrina - IPAC/LDA.

Portanto, no período compreendido entre 1930 e o final da década de 1940, houve o assentamento de Londrina, além de sua elevação à condição de município na hierarquia administrativa do Paraná e da chegada da ferrovia. Também neste período, esboçaram-se os primeiros fatores de desestruturação urbana mediante o surgimento de várias vilas em áreas periféricas e carentes de planejamento. Concomitantemente, o centro histórico da cidade, definido pelo plano inglês reticulado, expressava, pelo conjunto de seus equipamentos urbanos e pelo cotidiano que ali era vivenciado, a forte polarização exercida pela cidade em suas primeiras décadas. Pois, nesta área estavam localizados os estabelecimentos destinados à comercialização dos produtos agrícolas e industrializados, às transações financeiras, bem como aqueles destinados à administração por parte das instituições públicas. Como afirma Castelnou (2002), este quadrilátero central inicial se definiu como o elemento primário mais importante da paisagem londrinense, tornando-se um dos condicionantes fundamentais para a futura expansão da malha urbana de Londrina. 


\subsection{O Ápice e o Declínio da Cafeicultura Norte Paranaense e Suas Implicações nas Relações Sócio-Espaciais em Londrina}

Apesar de a cafeicultura ter sido implantada no Norte Central do Paraná nas décadas de 1920 e 1930, como a própria base para sua ocupação, foi na década de 1950 que esta atividade aumentou sensivelmente na região. Foi principalmente em função das vantagens econômicas proporcionadas pela cafeicultura que Londrina viveu seus "anos dourados" nesta década. Como a cidade que mais crescia no Norte do Paraná, cada vez mais, Londrina passava a ser vista como protótipo de pujança por sua população, sendo até mesmo percebida “[...] como uma nova metrópole que surgia em território nacional" (LINARDI, 1995: 172), não apenas pelo ritmo intenso de sua construção, mas também por sua similaridade, em alguns aspectos, se comparada aos maiores centros urbanos brasileiros da época.

O surto cafeeiro no Norte do Paraná iniciou-se mais efetivamente após a Segunda Guerra Mundial (1939 - 1945) em decorrência de uma série de acontecimentos que impulsionou os preços do café, contribuindo também para um espantoso aumento dos índices de produtividade na região. Entre estes acontecimentos destacam-se o reaquecimento do mercado internacional, proveniente do maior consumo de café e derivados na Europa e nos Estados Unidos; a criação, em 1952, do Instituto Brasileiro do Café (IBC), para a execução da política intervencionista no setor ${ }^{12}$; e a ocorrência de fortes geadas na região entre 1953 e 1955, com a conseqüente valorização do produto (ALMEIDA, 1981; LINARDI, 1995; FRESCA, 2004). Isso tudo, aliado à fertilidade do solo e à facilidade de escoamento da produção pelas estradas que serviam à região, levou o Paraná a assumir a dianteira como principal produtor brasileiro de café, deslocando a hegemonia paulista que se estabelecia até então.

Mediante esta conjuntura, a cidade de Londrina se fortaleceu ainda mais enquanto pólo regional, uma vez que se constituía enquanto responsável pela organização do comércio e pela exportação do café, assim como pelas atividades que

\footnotetext{
12 Esta política intervencionista refere-se ao fato de que, dada a superprodução cafeeira ocorrida no mercado internacional durante a década de 1950, o governo brasileiro acabou por adotar medidas buscando a retração forçada da oferta, e, consequentemente, valorizando o produto. Estas medidas expressam-se, principalmente, pela destruição de boa parte da produção brasileira e pelo controle rigoroso sobre a expansão da cafeicultura em outros estados, sobretudo em São Paulo (ALMEIDA, 1981).
} 
lhe eram complementares. Foi, principalmente, a partir da cafeicultura que a cidade adquiriu não apenas uma projeção nacional, como importante núcleo urbano do interior do país, mas também internacional, a partir de quando passou a ocupar a posição de “capital mundial do café”. Em vários segmentos e sob diferentes formas a prosperidade cafeeira se manifestava na cidade. Como destaca Linardi:

Vivia-se em Londrina sob o brilho e expressão do café [...] Foi, sem dúvida, o café que definiu o perfil da cidade e do londrinense, unindo diferentes segmentos da sociedade e criando a inter-relação entre o urbano e o rural. A forma da ocupação e a estrutura agrária, as trocas e a intermediação urbana, os investimentos e todo o movimento financeiro, a vida urbana, enfim, apresentava um elemento determinante comum, o café (1995: 170).

A grande expansão urbana e o elevado crescimento demográfico observados em Londrina durante a década de 1950, de certa forma, estiveram associados às referidas geadas que na época assolaram o Norte do Paraná, provocando as primeiras migrações campo-cidade mais intensas na região. Contudo, o crescimento da cidade neste período se deu, principalmente, pela diversificação e sofisticação de seu setor terciário. Afinal, neste momento não se tratava apenas de atender uma demanda local e regional de origem basicamente agrícola, mas de servir com requinte a uma burguesia local que se formava desde a década anterior e que agora se consolidava pelos rendimentos da cafeicultura. Esta expansão do setor terciário em Londrina expressava-se pelo surgimento de lojas grã-finas, salões de chá, e outras formas de consumo modernas, além do aumento e melhoria dos serviços médico-hospitalares, de transporte, no ensino superior - com a criação, em 1956, da Faculdade Estadual de Direito - e nos prédios públicos e privados, elaborados por arquitetos de renome nacional. Com a implantação destes serviços, Londrina demonstrava uma superioridade qualitativa evidente em relação aos demais núcleos urbanos da região, atraindo tanto uma mão-de-obra de origem rural, normalmente desqualificada para os serviços urbanos, quanto trabalhadores qualificados para o exercício das funções técnicas e administrativas que a cidade demandava.

A partir deste movimento, intensificou-se uma nova configuração urbana em Londrina. Primeiramente, pelo elevado contingente de migrantes rurais que chegava à cidade, quase sempre ocupando a periferia, cresciam os "vazios urbanos" e tornava-se 
mais acentuada a segregação espacial. Aquele "zoneamento" até certo ponto espontâneo - pois não era formalizado -, esboçado nas primeiras décadas da cidade, tornava-se mais vigoroso, passando a ser perceptível a configuração de áreas mais "nobres" enquanto outras se definiam como mais "populares". Como observa Linardi, com apenas duas décadas de existência, "[...] vazios urbanos, especulação, segregação espacial, expansão da periferia, entre outros problemas ou características da cidade moderna, já faziam parte do repertório dessa cidade" (1995: 184). Porém, as transformações mais notáveis na paisagem urbana londrinense durante a década de 1950 referem-se ao surgimento precoce de vários edifícios verticais nesta área. Pela elevada extensão de "vazios" na malha urbana, evidentemente estes edifícios, construídos sobre os preceitos da arquitetura modernista, não surgiam como índice de falta de espaço, mas para atestar a riqueza e o rápido "progresso" atingido pela cidade. Além disso, a implantação destes exemplares modernistas representava também a confiança que os investidores da época depositavam em Londrina e a sua afirmação enquanto pólo de desenvolvimento da região norte paranaense.

A disseminação destas edificações modernistas em Londrina se deve, sobretudo, ao arquiteto Vilanova Artigas e seu sócio Carlos Cascaldi. Artigas é considerado ainda hoje como um dos grandes nomes da arquitetura brasileira pós-Brasília e suas obras em Londrina tiveram uma repercussão considerável na paisagem local, simbolizando as transformações vigentes tanto ao nível da mentalidade como da imagem urbana da então “capital mundial do café”. A partir de um convite do prefeito Hugo Cabral (1947 1941), Artigas e Cascaldi desenvolveram 06 projetos de envergadura para a cidade: a Antiga Estação Rodoviária, onde atualmente funciona o Museu de Arte de Londrina; o Cine Ouro Verde e o edifício Autolon, construídos lado a lado na Avenida Paraná; a Casa da Criança, onde hoje está instalada a Secretaria Municipal de Cultura; além do Estádio Municipal e do Aeroporto, que não foram executados. As experiências realizadas por Artigas e Cascaldi em Londrina constituíram-se como marcos referenciais fundamentais para a cidade e para sua representação enquanto pólo irradiador do desenvolvimento da região norte paranaense. Suas obras, marcadas por concepções estéticas e por técnicas de resolução muito inovadoras para a época, traziam embutidas em suas formas racionalistas os ideais de progresso que se tinha naquele momento em todo o país. 


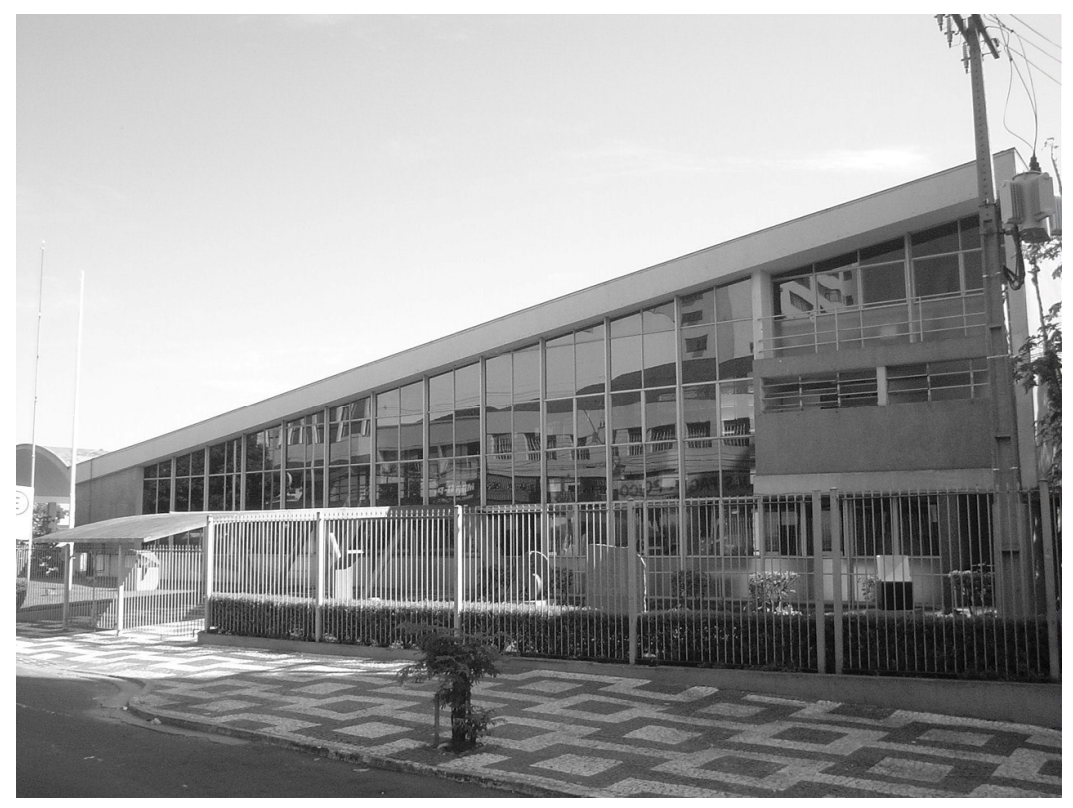

Foto 2. Antiga Estação Rodoviária e atual Museu de Arte de Londrina (1952), considerado como a principal obra arquitetônica da cidade.

Fonte: Vinicius Aguiari (Acervo Pessoal).

Tanto a Antiga Estação Rodoviária, ${ }^{13}$ inaugurada em 1952, quanto a Casa da Criança, obra mais tardia de Artigas e Cascaldi, de 1954, possuem basicamente a mesma tipologia das residências paulistanas projetadas pela dupla de arquitetos neste período. Conforme análise de Castelnou (2002), a primeira destas obras mostra-se particularmente interessante, sobretudo, pelo fato da edificação caracterizar-se como mediadora de duas faces de Londrina. Pois, implantada com objetivo de valorização das vistas, por sua transparência o prédio da Antiga Estação Rodoviária permitia que seus usuários avistassem, ao norte, as grandes plantações de café, o campo e a ferrovia, que denunciavam uma cidade alicerçada no meio rural, enquanto que ao sul, via-se, em conjunto, boa parte de seus equipamentos urbanos e a "selva de pedra", símbolos da pujança e do progresso londrinense.

Da mesma forma, as demais obras de Artigas e Cascaldi em Londrina - o Cine Ouro Verde e o Edifício Autolon (1951) - também contribuíram para a construção de

\footnotetext{
${ }^{13}$ Por sua beleza, funcionalidade e pela carga que simbólica que esta edificação possui, esta foi a primeira obra modernista a ser tombada como patrimônio histórico e artístico no Brasil, em 1974. Mediante a construção de um novo terminal rodoviário em Londrina, em 1988, a garantia de uso e preservação da Antiga Estação Rodoviária se deu por sua restauração e reciclagem, para que o prédio abrigasse o Museu de Arte de Londrina, inaugurado em 1993. Apesar destas modificações, atualmente a obra mantém suas características, mostrando-se como um importante testemunho dos "anos dourados" em Londrina.
} 
uma imagem moderna e arrojada para a cidade. Especialmente o Cine Ouro Verde, inaugurado em 1952, transformou-se em um dos grandes marcos de ostentação cultural para os londrinenses, sobretudo, por sua programação voltada aos setores mais "intelectualizados" da população e por seus padrões equiparáveis aos maiores cinemas das grandes cidades brasileiras. Ao lado desta edificação está localizado o Edifício Autolon, segundo prédio a ser construído no boom da verticalização londrinense, em 1951. Não apenas pela materialidade destes equipamentos urbanos, mas também pelo fasto cotidiano que ali era vivenciado, este conjunto de edificações também remete à atmosfera de progresso e desenvolvimento experimentado pela cidade na década de 1950.

Além dessas obras essenciais, muitas outras edificações da década de 1950 contribuíram para a formação de um panorama modernista em Londrina. A maioria destas obras constitui-se enquanto edifícios verticais, construídos por empresas de São Paulo que empregavam os mesmos elementos arquitetônicos utilizados na capital paulista nesta época. Parte destas obras está localizada na Avenida Paraná e em suas proximidades, com destaque para o conjunto de edifícios "Centro Comercial” e para os prédios "América", "Bosque" e "Comendador Júlio Fuganti", o "Sahão Palace Hotel”, o "Edifício Sahão" e a "Concha Acústica". Portanto, com apenas duas décadas de existência, Londrina já apresentava marcas de uma arquitetura modernista em muitos de seus edifícios, na mesma época em que esta concepção estética abria espaços para a discussão e experimentos nos maiores centros urbanos do Brasil e do exterior.

Contudo, a rápida absorção de uma arquitetura que expressasse desenvolvimento e sintonia com os grandes centros urbanos do país implicou também em um intenso processo de renovação urbana, onde construções recentes, testemunhos do desbravamento da região norte paranaense e do surgimento da cidade, foram precocemente superadas. Efetivamente, o lastro proporcionado pelo "ouro verde" na década de 1950, imprimiu um ritmo de expansão acelerado em Londrina, não se tratando apenas da ampliação de sua malha urbana, mas também de profundas transformações em sua paisagem, especialmente, em sua área mais central, onde se proliferavam os símbolos de uma cidade moderna, como se pode observar no mapa abaixo: 


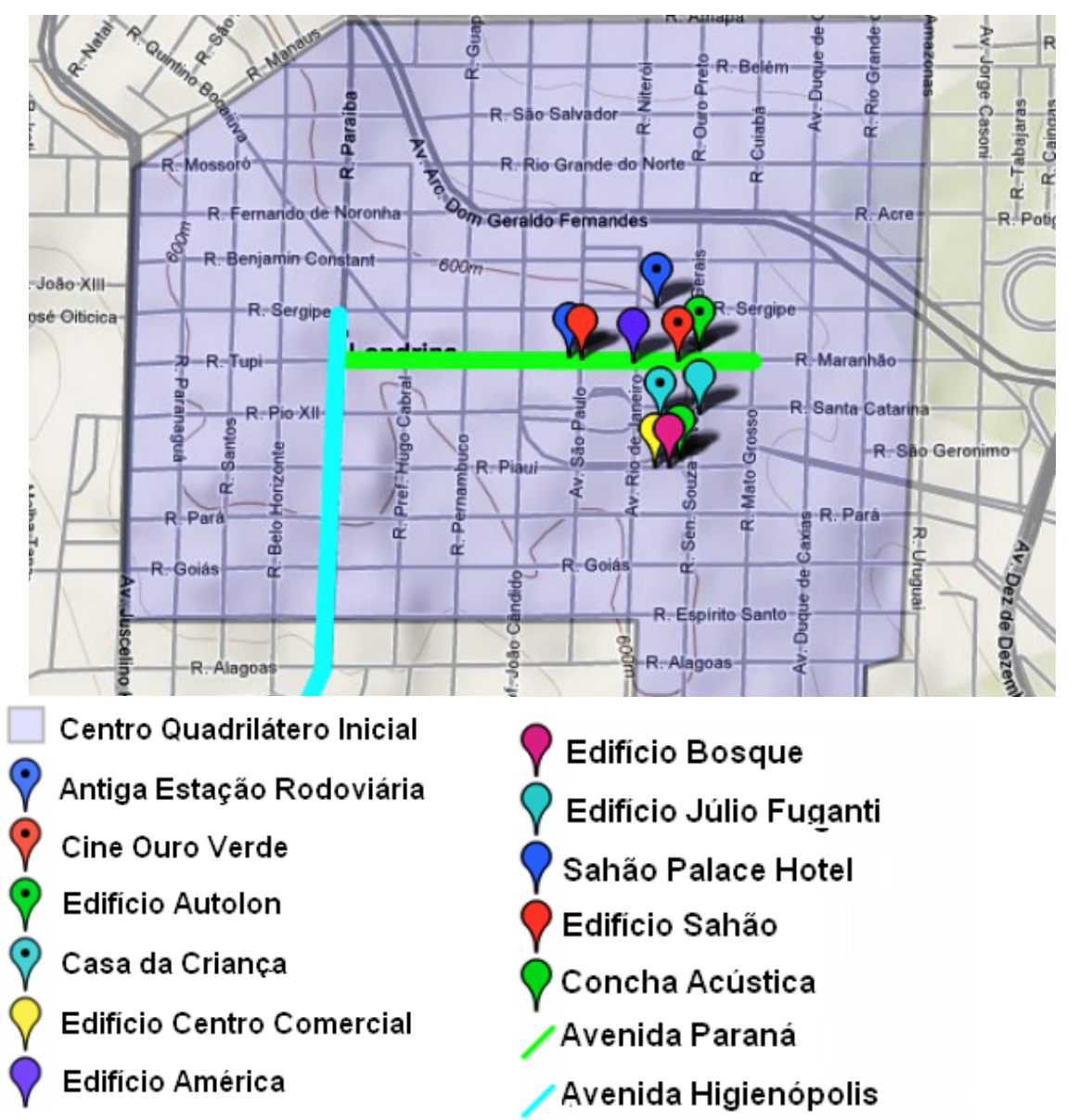

Mapa 4. Localização das edificações modernistas da década de 1950 em Londrina. Fonte: www.google.maps; editado pelo autor.

Foi no final da década de 1950 que a cafeicultura norte paranaense atingiu seu ápice para em seguida, e com a mesma intensidade de sua expansão, também experimentar seu declínio. Este movimento se deu, primeiramente, tanto pelo esgotamento da fronteira agrícola na região, quanto pela própria crise da superprodução cafeeira na época. Pois, na passagem da década de 1950 para 1960 o Paraná, sobretudo, em sua região norte, passou a produzir mais café do que era efetivamente vendido no mercado, implicando na formação de estoques, e, consequentemente, na queda dos preços. A partir de então a cafeicultura já não se mostrava tão rentável quanto nas décadas anteriores. Além disso, este momento também fora marcado pela convergência entre mudanças políticas, econômicas e sociais em no contexto nacional e mundial, 
implicando no desenvolvimento de novas formas de exploração das terras no Norte do Paraná. Desta forma, visto que, até então, a ocupação e o desenvolvimento desta região tiveram a cafeicultura como seu fio condutor, o declínio desta atividade anunciou o fim de um período significativo para Londrina, delineando um novo momento para seu desenvolvimento urbano.

Ao mesmo passo em que se davam os efeitos do esgotamento da fronteira agrícola e da superprodução cafeeira no norte paranaense, o Brasil "pós-1964” também passava a ser comandado por um Estado autoritário, marcado por uma mudança de orientação na política externa, que agora buscava apoio econômico, político e militar nos Estados Unidos. Como representante desta fração hegemônica, o governo brasileiro passou, então, submeter-se às exigências de uma nova ordem econômica mundial, que se caracterizava, sobretudo, pelo comprometimento com a reprodução do capital industrial. Neste contexto, no que se refere ao Norte do Paraná, é marcante o fato desta região possuir poucas unidades industriais, especialmente, em decorrência de seu abastecimento, desde a sua ocupação, pelos produtos industrializados vindos de São Paulo. Almeida (1981) observa que é até mesmo possível afirmar que o norte paranaense tenha se "desindustrializado" durante o período de expansão cafeeira; pois, segundo a autora, se em termos absolutos o setor industrial crescia, sua participação relativa na renda gerada pela economia do estado declinava, cada vez mais, em detrimento do grande dinamismo do setor agrícola.

Dado o fato de que até 1960 o Paraná se inseria na divisão territorial do trabalho brasileira ocupando uma posição quase que unicamente agrícola, iniciaram-se uma série de intervenções estatais a fim de dar suporte para que este estado tivesse outro papel no cenário econômico nacional. Afinal, se neste momento em todo o Brasil "[...] a industrialização destacava-se como sinônimo de desenvolvimento" (FRESCA, 2004: 169), tornava-se necessário, então, romper com o relativo empobrecimento que o Norte do Paraná sofria. Contudo, as intervenções estatais na economia paranaense a partir de 1960 se deram com objetivos distintos dos procedimentos anteriores. Se desde 1929 as intervenções referentes ao Paraná se deram pela retirada de subsídios à cafeicultura, provocando uma retração forçada da oferta, e pela retenção dos lucros para transferi-los 
ao processo de industrialização paulista, a partir de então estas intervenções buscavam criar condições para a modernização da agricultura ${ }^{14}$.

Primeiramente buscou-se a eliminação dos pés de café com baixo rendimento, destinando as terras liberadas para outros usos; principalmente para a pecuária, culturas alimentares e matérias-primas que demandassem a incorporação de máquinas e insumos, agora produzidos no Brasil. Ao mesmo passo, as plantações cafeeiras restantes foram modernizadas sob forte subsídio estatal. A agricultura norte paranaense passava, então, a se reestruturar a partir de sua inclusão imediata no circuito industrial, seja como produtora de matérias-primas para transformação ou como consumidora de insumos e maquinários, transformando-se em excelente mercado para a indústria. Ainda, para além da modernização do processo produtivo agrícola, a partir deste movimento de vinculação da agricultura à reprodução do capital industrial também surgiram as chamadas "agroindústrias".

Conforme o conceito utilizado por Almeida (1981), estas agroindústrias se caracterizam por um esquema interativo que abrange tanto as indústrias que utilizam matérias-primas de origem agrícola, como as que produzem bens de utilização pela agricultura. Com o surgimento destas indústrias especializadas na década de 1960, o Norte do Paraná passou a se integrar mais efetivamente à economia brasileira a partir da redefinição de sua participação na divisão territorial do trabalho. Especialmente a cidade de Londrina, como pólo econômico desta região, assumiu uma posição de destaque no setor agroindustrial, que atualmente representa mais da metade das indústrias paranaenses. De maneira geral, com o advento das agroindústrias criou-se no Paraná uma cópia tardia do projeto desenvolvimentista nacional, que já se observava nos centros hegemônicos do país desde 1930, onde o Estado assumiu o papel de conduzir a economia mediante investimentos na industrialização. Afinal, se desde a sua ocupação o Norte do Paraná se caracterizou pela exportação de produtos primários, nesta região a industrialização foi alcançada pela articulação entre seu potencial agrícola e as demandas pela reprodução do capital industrial que se tinha no momento, tanto em âmbito nacional como internacional.

\footnotetext{
${ }^{14}$ Pois, apesar da agricultura no norte paranaense, desde o seu início, ter destinado sua produção ao mercado, esta ainda não era provida de um caráter moderno. Na medida em que o processo produtivo referente à cafeicultura baseava-se na mão-de-obra familiar, com emprego de tecnologia rudimentar e baixa demanda por insumos industriais, tornou-se necessária uma adaptação da produção agrícola norte paranaense às novas tendências da economia nacional e internacional.
} 
Esta nova política agrícola, de subordinação da agricultura à indústria, implicou na transformação da base produtiva do campo sob a forma de tecnificação e aumento do uso de insumos, com impacto direto na produtividade da terra, tornando-a menos dependentes dos recursos naturais e da força de trabalho. A diversificação da atividade agrícola no Norte do Paraná também teve impactos na modificação da estrutura agrária da região, já que para os novos cultivos ali introduzidos, as grandes e médias propriedades eram requisitos básicos. Estas modificações nas bases técnicas e na estrutura fundiária da região, com maior concentração na posse de terras, culminaram em um grande esvaziamento do campo. Os antigos colonos do café, desvinculados da terra, passaram a migrar em massa para regiões de fronteira agrícola em outros estados ou para as cidades em busca de trabalho e sobrevivência. Portanto, as consequiências destas transformações em toda a agropecuária nacional se deram não apenas do ponto de vista produtivo, mas também das relações sociais no campo, com mudanças qualitativas e quantitativas significativas em algumas cidades.

No contexto norte paranaense, ainda que esta região passasse a esboçar uma tendência nacional, onde o Brasil deixava de ser predominantemente agrícola, ali os índices de êxodo rural e de urbanização mostravam-se extremamente acentuados. Pois, na mesma medida em que durante todo o período de expansão da cafeicultura a região vivenciou um dos maiores surtos demográficos já vistos no país, havia também um imenso contingente populacional para ser liberado do campo. Esta população que migrava para as cidades, em grande parte, se dirigia para os pólos regionais que já possuíam alguma expressão anterior - especialmente Londrina e Maringá - em busca de serviços urbanos. Sobretudo Londrina seguiu crescendo e acentuando sua população, com o censo de 1960 revelando a inversão em termos de distribuição populacional onde o contingente urbano da cidade representava um percentual de $57,40 \%$, enquanto que nas demais cidades da região este índice era, em média, de apenas 22\% (FRESCA, 2004). Já no censo de 1970, a população urbana de Londrina representava 71,69\% deste quadro (PERFIL..., 2003: 39).

Além disso, a crescente urbanização de Londrina a partir deste período está igualmente associada à chegada da mão-de-obra qualificada na cidade. Afinal, a nova política agrícola nacional proporcionou o desenvolvimento de um setor agroindustrial no norte paranaense com forte demanda por tecnologia e pessoal especializado a fim de atender ao aperfeiçoamento lógico destas atividades. Havia também, desde a década de 
1950, uma ampliação significativa do setor de serviços na cidade, com exigência da qualificação da mão-de-obra. Como destaca Fresca (2004), além dos serviços básicos, nesta época Londrina também já concentrava aqueles mais complexos, como clínicas cirúrgicas, administrativos em nível jurídico, escritórios de advocacia, além de assistência técnica e profissional em nível superior. Portanto, mediante as transformações da estrutura agrária na região norte paranaense, enquanto algumas cidades decresceram ou se estagnaram, outras, como é o caso de Londrina, tornaram-se ainda maiores, reafirmando suas posições anteriores de pólos regionais.

\begin{tabular}{|c|c|c|c|c|c|}
\hline & \multicolumn{2}{|c|}{ Urbana } & \multicolumn{2}{c|}{ Rural } & Total (100\%) \\
\hline Ano & Número & $\%$ & Número & $\%$ & Número \\
\hline 1950 & 34.230 & 47,93 & 37.182 & 52,07 & 71.412 \\
\hline 1960 & 77.382 & 57,40 & 57.439 & 42,60 & 134.821 \\
\hline 1970 & 163.528 & 71,69 & 64.573 & 28,31 & 228.101 \\
\hline
\end{tabular}

Tabela 1. Evolução da população residente no município de Londrina (1950 - 1970). Fonte: IBGE - Censos demográficos 1950, 1960, 1970. In: Perfil 2003 - Prefeitura Municipal de Londrina.

Se na década de 1950 as transformações mais notáveis da paisagem urbana de Londrina se deram na área central, no contexto da década de 1960 as mudanças mais marcantes estiveram ligadas ao expressivo aumento da periferização na cidade. Pois, em decorrência do intenso êxodo rural os limites da malha urbana passaram a ser ocupados mediante o incentivo de programas municipais de desenvolvimento, cujo objetivo era instalar esse contingente que chegava do campo. Contudo, a expansão exacerbada da periferia londrinense nesta época não correspondia às necessidades reais da cidade, que contava em seu núcleo mais central com lotes urbanos ainda desocupados. Como observa Castelnou (2002), esta nova tendência na configuração da paisagem urbana de Londrina refletia, acima de tudo, estratégias de especulação imobiliária traçadas pelo poder público e pelo capital privado, que, ao implantar tais moradias nas franjas da 
cidade, buscava valorizar os "vazios urbanos" deixados entre o centro e as áreas limítrofes e periféricas, elevando o custo dos serviços e equipamentos nestes espaços.

Logo, datam da década de 1960 os primeiros conjuntos habitacionais de Londrina, situados a uma distância de cerca de 6 a $7 \mathrm{~km}$. ao norte do núcleo urbano central. A proliferação destes conjuntos habitacionais "segregados da cidade" e a criação de vazios urbanos foram tão intensas que no início da década, em 1963, o poder

público local viu-se obrigado a estabelecer uma lei de zoneamento procurando ordenar a intensa expansão urbana que se tinha na época. A partir deste procedimento estabeleciase, antes da metade da década de 1960, uma projeção para os próximos 15 anos, que buscava consolidar Londrina enquanto centro agroindustrial, comercial, cultural e de serviços para toda a população do Norte do Paraná. Assim, Londrina entraria na década de 1970, mais uma vez, como uma cidade em crescimento; mas agora este processo não tinha mais como base o "ouro verde", como no período inicial de sua ocupação, mas sim a sua afirmação como um dos pólos agroindustriais mais expressivos do país.

\subsection{Tendências Recentes de Expansão da Malha Urbana Londrinense}

De maneira geral, as transformações que passaram a vigorar na sociedade brasileira na década de 1960 continuaram a ser singularizados em Londrina ao longo da década de 1970. Mas enquanto neste momento a economia nacional já havia reduzido seu ritmo de crescimento - sobretudo pelos efeitos de uma fase recessiva internacional inaugurada em 1973 com a "Crise do Petróleo" -, o estado do Paraná adentrava, desde a década anterior, em um momento de forte dinamismo econômico, com consequiências sócio-espaciais significativas em suas maiores cidades.

O menor impacto sofrido pelo estado do Paraná neste período recessivo refere-se ao fato de sua geração de renda estar associada, principalmente, à agropecuária e ao crescente setor agroindustrial no norte do estado, que não foram tão profundamente afetados pela crise que se estabelecia. Pela continuidade na expansão da agropecuária, especialmente sob os cultivos ligados diretamente às agroindústrias, as taxas de crescimento do Produto Interno Bruto (PIB) paranaense apresentavam um desempenho 
satisfatório em comparação ao contexto nacional. Como observa Fresca (2004), com este quadro econômico ascendente, em 1976 a economia paranaense finalmente experimentou, mediante o crescimento e participação das agroindústrias, um ritmo de crescimento do setor industrial muito mais elevado que o da agricultura, com a predominância do primeiro na geração da renda interna do estado. Ao término da década de 1970 o Paraná já havia consolidado sua nova inserção na divisão territorial do trabalho em âmbito nacional e internacional, passando da condição de exportador agrícola de gêneros alimentícios semi-elaborados para a condição de industrializado, centrado nas agroindústrias alimentícias.

O fato de nesta década apenas Londrina, e mais 06 núcleos urbanos do Norte do Paraná, contarem com uma população majoritariamente urbana denuncia a crescente centralização da cidade em relação à região, além do intenso êxodo rural em sua direção, principalmente, por conta das transformações da estrutura agrária no norte paranaense. Tanto pelo expressivo movimento migratório, referente à população rural que chegava à Londrina, como também pelas altas cifras advindas do setor agroindustrial e das atividades urbanas - como o comércio e os serviços -, a segregação espacial na cidade tornou-se ainda mais nítida. De maneira geral, enquanto as classes mais abastadas que usufruíam dos lucros referentes às atividades urbanas tendencialmente ocupavam a área central e os quadrantes sul-sudoeste da malha urbana, a população de mais baixa renda ocupava predominantemente a periferia na região norte de Londrina.

No que se refere à expansão da periferia londrinense neste período, até o meio da década de 1970 os conjuntos habitacionais construídos pelo poder público, apesar de numerosos, eram notadamente pequenos, ocupando espaços ainda vazios da malha urbana. Contudo, é notável que a partir de 1976, quando passou a predominar o capital industrial na cidade, iniciou-se a construção de conjuntos habitacionais gigantescos, como próprio reflexo da mudança na estrutura agrária da região. Apesar dos primeiros conjuntos habitacionais terem surgidos na década de 1960, foi em meados da década de 1970 que esse sistema ganhou verdadeiro impulso com a construção dos "Cinco Conjuntos", situado ao norte do núcleo urbano central, próximo ao recente parque industrial. Estes conjuntos, pejorativamente denominados pela população local como "Cincão", ocupados majoritariamente por um contingente de baixa renda, possuíam a fisionomia e a infra-estrutura de uma nova "cidade à parte" na periferia de Londrina. 
Mediante toda a infra-estrutura dotada pelo poder público local a esta nova área incorporada ao perímetro urbano, os vazios que passaram a existir entre a malha urbana anterior e área de localização destes conjuntos foram fortemente valorizados, contribuindo ainda mais para a especulação imobiliária na cidade.

Foi no início da década de 1970 que também se iniciou a expansão da malha urbana de Londrina em direção ao sul e sudoeste do núcleo central. Inicialmente esta expansão se deve à instalação da Universidade Estadual de Londrina (UEL), em 1971, no quadrante sudoeste da cidade, abrindo caminho para a ampliação do centro nesta direção. Com a criação da UEL, juntamente com a do Centro de Estudos Superiores de Londrina (CESULON) - posteriormente transformado no Centro Universitário Filadélfia (UNIFIL) -, a partir desta década Londrina também se tornou um pólo educacional, disseminando saberes técnicos em sua região e formando estudantes provenientes de diversas cidades do Brasil ${ }^{15}$. Além disso, a revitalização do Lago Igapó - construído em 1959, com uma proposta de Burle Marx, considerado o maior paisagista brasileiro - contribuiu para a expansão da malha urbana no sentido sul. Após a construção de sua barragem e de sua urbanização no final da década de 1970, este passou a ser o mais enfático cartão postal da cidade, transformando-se em uma zona especial de chácaras e casas de segunda residência para a alta elite londrinense em plena Avenida Higienópolis.

Nesta década também surgiu um plano para a reestruturação da área central de Londrina, onde se concentravam os principais serviços urbanos. Em 1977 realizou-se o calçamento de parte da Avenida Paraná, criando-se o chamado "calçadão", como uma iniciativa que marcaria uma série de intervenções da administração municipal sobre o núcleo pioneiro na década seguinte. A partir da década de 1970, a cada intervenção feita pela prefeitura nas décadas posteriores passou a ser mais evidente a tendência de crescimento e expansão da cidade rumo aos setores sul-sudoeste como setor das camadas sociais mais privilegiadas, e rumo ao norte como o das camadas mais populares.

\footnotetext{
${ }^{15}$ Além destas universidades citadas, atualmente estão localizadas em Londrina mais quatro instituições expressivas no contexto norte paranaense - a Universidade Norte do Paraná (UNOPAR), a Faculdade Metropolitana, a Faculdade Pitágoras, além de um campus da Pontifica Universidade Católica (PUC PR) -, que fazem da cidade uma referência no "turismo científico" (GRASSIOTO \& GRASSIOTO, 2003), como sede de eventos e congressos nas mais variadas áreas técnicas e acadêmicas.
} 
Já na década de 1980, continuaram se seguindo as grandes tendências dos anos anteriores, como a continuidade de conjuntos habitacionais na zona norte e o desenvolvimento de programas de renovação urbana na área central. Mas, se por um lado, na década de 1980 persistiu a oferta de moradia para a população de menor poder aquisitivo, por outro, neste período houve um acirramento dos conflitos sociais entre o contingente populacional que não obteve habitação das iniciativas da administração municipal. Esta situação implicou em uma intensa proliferação de favelas e assentamentos urbanos ${ }^{16}$ na paisagem de Londrina, principalmente nas porções norte e extremo sul da cidade, enquanto que na área central ocorria uma forte aliança da administração pública para com o capital comercial através de programas como o "Projeto Centro", que visava valorizar esta área.

Dentre as medidas mais marcantes do "Projeto Centro" estava a retirada da linha férrea, que cortava toda a região central, além da criação de uma nova lei de zoneamento, que incentivou o crescimento e ratificou uma ocupação que vinha se processando já há algum tempo. Dessa lei resultou a intensificação do processo de verticalização na área central da cidade a partir da construção de vários edifícios imponentes, que em sua maioria se localizavam nas proximidades da Avenida Higienópolis. Se a produção de edifícios verticais em Londrina foi bastante precoce, iniciando-se já na década de 1950, foi na década de 1980 que este processo assumiu grandes dimensões, não mais como ostentação do "progresso", mas também como uma área de investimento na qual a reprodução de capital mostrava-se bastante viável. Ao final da década de 1980, o preço mais elevado do solo em Londrina referia-se ao quadrilátero formado pela Avenida Higienópolis, e pelas ruas Goiás, Paranaguá e Sergipe.

Contudo, uma outra tendência de expansão territorial passou a se delinear na década de 1990, quando foi inaugurado o Catuaí Shopping Center no quadrante sudoeste da malha urbana de Londrina. Como analisa Fresca (2002), as condições para sua implantação favoreceram muito a descentralização urbana rumo a este setor. Pois, a escolha do local para a construção deste shopping seguiu critérios bastante comuns para empreendimentos desta natureza, sempre vinculados à especulação imobiliária.

\footnotetext{
${ }^{16}$ Segundo Fresca (2002), tanto os assentamentos urbanos quanto as favelas se caracterizam como áreas invadidas pela população de baixa renda, dispersos por todo o entorno da malha urbana, aproveitando-se de áreas vazias pertencentes ao poder público local. Contudo, os primeiros diferem das segundas pela presença de uma infra-estrutura que, ainda que precária, lhe confere certo aspecto de ordem urbanística.
} 
Primeiramente, a autora destaca que o local onde fora implantado o Catuaí Shopping Center está relativamente afastado da área de maior densidade da população, principalmente, para que se garantisse a existência de espaço o suficiente para a posterior valorização no entorno desta edificação. Além disso, esta área caracteriza-se também por sua proximidade às principais vias de circulação local e regional, já que o terreno escolhido para a construção do shopping está às margens da rodovia PR-445, que liga que liga o norte ao sul do estado do Paraná, e é de fácil acesso à BR-369, que liga a região norte-paranaense ao estado de São Paulo.
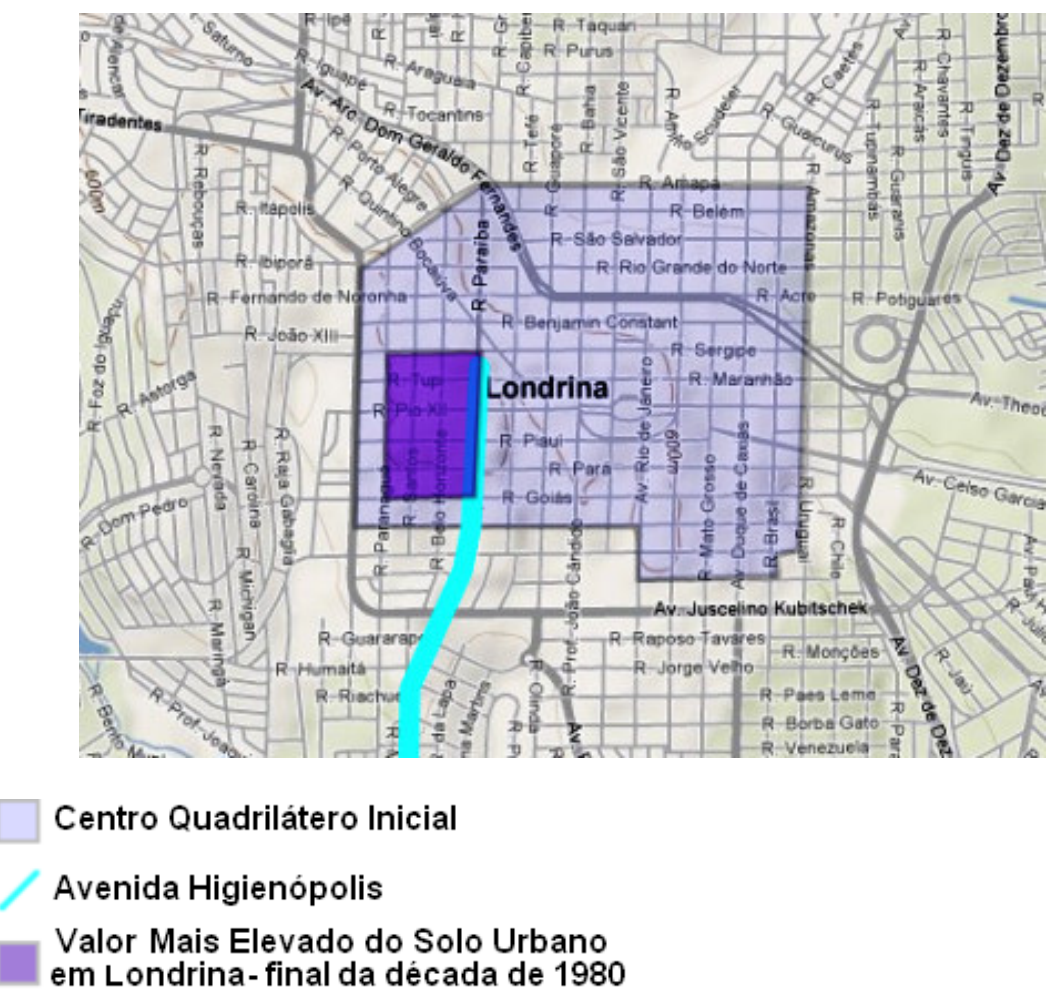

\section{Mapa 5. Quadrilátero referente ao preço mais elevado do solo urbano em Londrina (Final da década de 1980). \\ Fonte: www.google.maps; editado pelo autor.}

Mediante a valorização dos quadrantes sul-sudoeste a partir da implantação do Catuaí Shopping Center, vários empreendimentos nesta área passaram a ser direcionados a uma população de alto poder aquisitivo, especialmente, mediante a criação de condomínios exclusivos de altíssimo padrão e de chácaras de lazer. No entanto a viabilização destes empreendimentos no entorno do shopping não foi imediata, tanto pela insegurança e pela instabilidade econômica do começo da década 
durante o governo Collor (1990 - 1992), como pela disposição de outras áreas altamente valorizadas na área central, que se configuravam como locais de elevado status social. Como analisa Fresca, a relativa demora na implantação de empreendimentos imobiliários nos quadrantes sul e sudoeste da cidade revela que, até então, “[...] a camada potencialmente compradora de imóveis nesta área, a considerava muito distante do centro da cidade, denotando [que] a elite ainda estava arraigada ao centro" (2002: 261).

Contudo, passado o primeiro qüinqüênio da década de 1990, esta área no entorno do shopping passou a ser mais efetivamente ocupada, contando atualmente com vários empreendimentos em curso e com grande expectativa para o surgimento de novos loteamentos. Conforme a tendência apontada por Grassioto \& Grassioto (2003) - onde o comércio acompanha o deslocamento do mercado consumidor -, com o surgimento destes bairros a zona comercial também passou a se expandir em direção ao shopping. O centro principal expandiu-se para a Avenida Higienópolis, reduto comercial das elites, ultrapassando o Lago Igapó e seguindo pela Avenida Madre Leônia Milito até o Catuaí Shopping Center ("Mapa 6", na página a seguir). A consolidação deste sentido de crescimento e desenvolvimento da cidade levou consigo, além do comercio, o sistema viário, a infra-estrutura urbana e o lazer. Desde então, os maiores investimentos, seja do setor público ou da iniciativa privada, se deram nessa direção, com grande valorização dos bairros localizados ao sul e sudoeste do núcleo central da cidade, como se observa nas ilustrações a seguir:

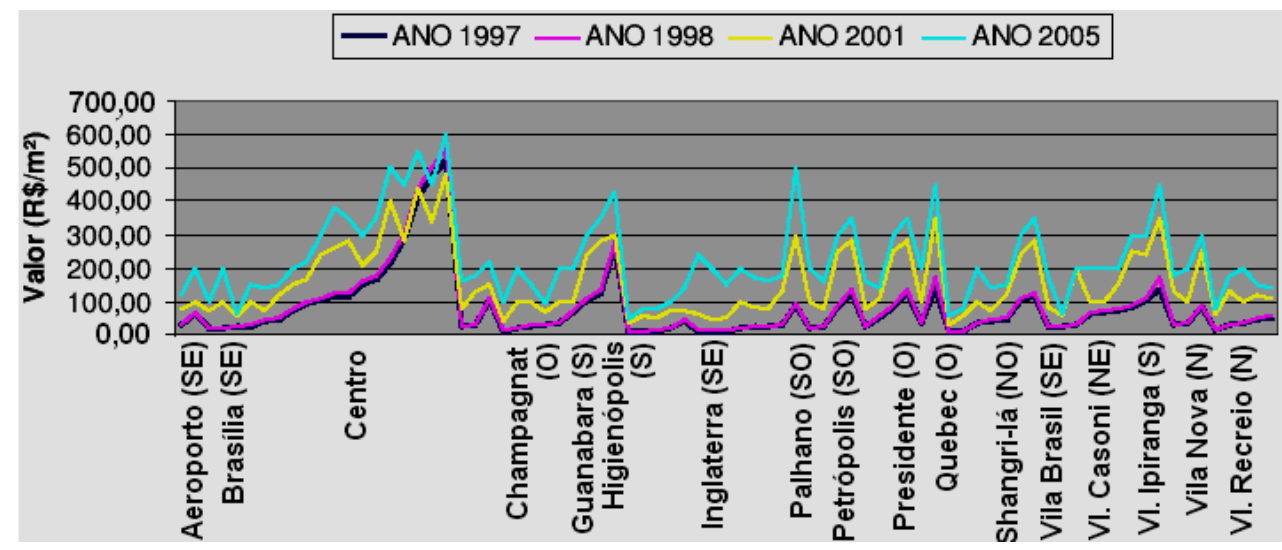

Gráfico 1. Valor do solo nos bairros verticalizados de Londrina. Fonte: Oura (2006); editado pelo autor. 


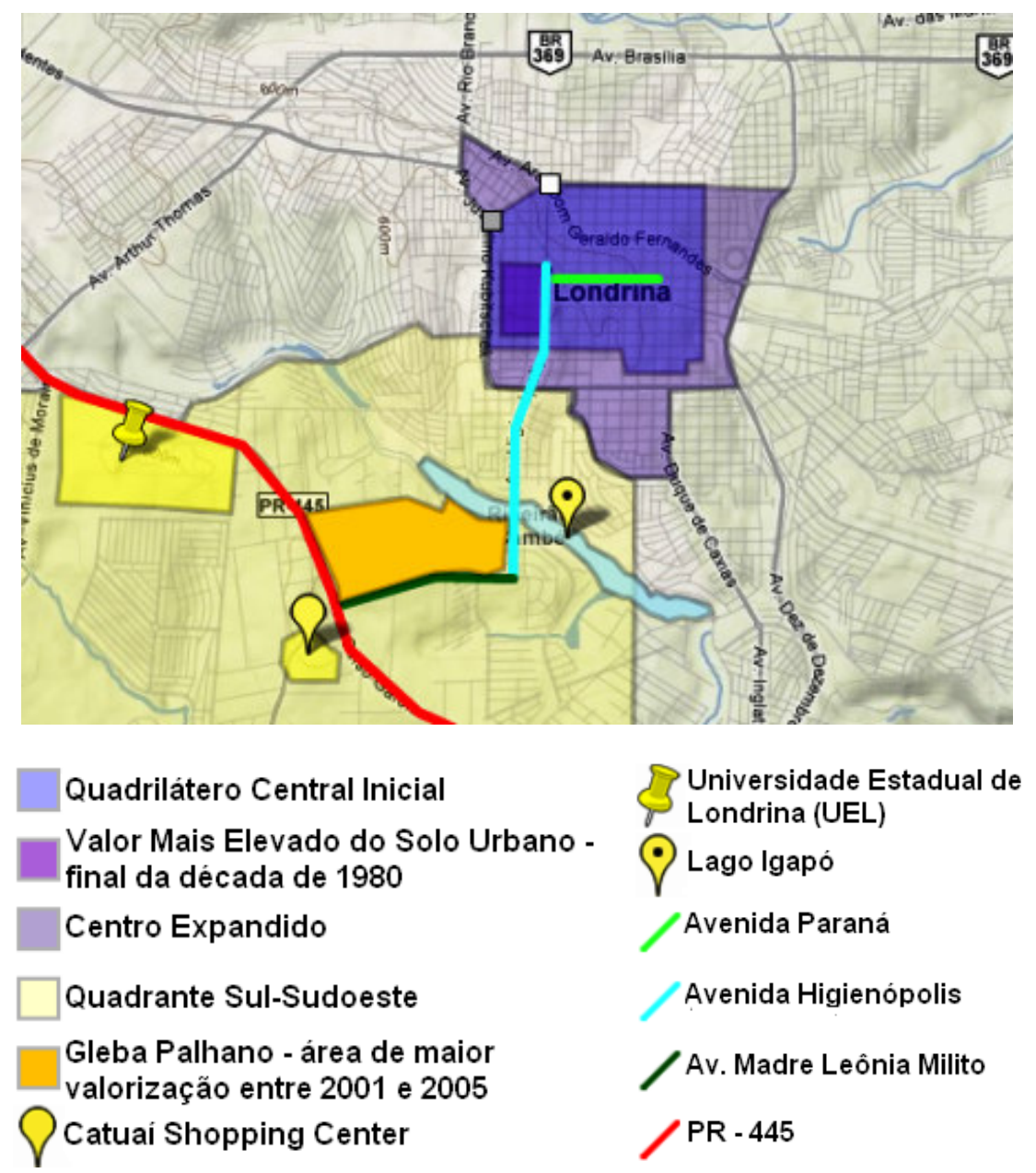

Mapa 6. Tendências recentes da expansão físico-territorial de Londrina (Quadrante sul-sudoeste). Fonte: www.google.maps; editado pelo autor.

Em junho de 1998 foi instituída a Região Metropolitana de Londrina, que além de sua cidade sede também compreende os municípios de Cambé, Jataizinho, Ibiporã, Rolândia, Tamarana, Bela Vista do Paraíso e Sertanópolis. Para Cunha (2005), apesar de esta região existir legalmente, ela não existe "de fato", mas apenas "no papel". Segundo o autor, sua criação foi parte de um processo iniciado em 1988, quando a nova constituição brasileira deu aos estados federados a prerrogativa de criar suas próprias regiões metropolitanas, iniciando-se a institucionalização desenfreada destas regiões no contexto de cidades médias em busca de status e recursos financeiros adicionais. Já para autores como Castelnou (2002), Londrina se constitui atualmente como uma área prémetropolitana, que passa por um processo de metropolização, especialmente, por fatores como a forte polarização exercida em sua região, a fisionomia de sua paisagem - 
altamente verticalizada -, a conurbação urbana existente entre os municípios de Cambé, Ibiporã e Londrina, e a intensa migração pendular entre estas cidades.

Visto que a discordância quanto ao fato de Londrina constituir-se enquanto uma metrópole não é o objetivo deste trabalho, por ora basta assinalar que atualmente a cidade passa por um momento diferenciado de sua expansão urbana. Conforme o histórico apresentado ao longo deste capítulo, desde o seu surgimento, na década de 1930, até a uma época muito recente - início da década 1990 -, o crescimento de Londrina se deu, principalmente, através de sucessivas transformações em sua área central e da proliferação exacerbada de suas áreas periféricas. Não restam dúvidas de que neste ínterim o centro da cidade foi uma região privilegiada para a aplicação de investimentos, tanto por parte do poder público quanto da iniciativa privada. Ali se concentraram não apenas os símbolos associados ao dinamismo e ao progresso econômico atingido pela cidade ao longo de sua história, como também grande parte dos equipamentos urbanos destinados ao comércio e aos serviços essenciais do município.

Embora a expansão horizontal da malha urbana londrinense tenha se iniciado já em suas primeiras décadas, com o surgimento de várias vilas segregadas do plano urbanístico original - intensificando-se, sobretudo, a partir de 1960 -, só muito recentemente tornou-se possível observar uma descentralização efetiva da cidade, especialmente, no que se refere ao desenvolvimento de novas áreas que realmente se integrem ao núcleo central. Pois, foi apenas a partir da década de 1990, sob o impulso dado pela implantação do Catuaí Shopping Center, que Londrina passou a contar concretamente com alguns "eixos de desdobramento" de sua área central, como a porção sul da Avenida Higienópolis e a Avenida Madre Leônia Milito, que pelo volume de investimentos que têm atraído mostram-se como áreas potenciais para a configuração de novos "subcentros". Mediante as tendências apresentadas neste capítulo, se a cidade passa por um processo de metropolização, ou se isso se dará apenas no futuro, o desenvolvimento destes eixos e o surgimento de novas expressões da centralidade em seu quadrante sul-sudoeste - em detrimento de outras áreas periféricas - parece ser o panorama de seu crescimento nas próximas décadas. 


\section{O BAR VALENTINO NO CENTRO}

No capítulo anterior fiz uma revisão acerca da história urbana de Londrina com ênfase em seus momentos mais marcantes. Com base em parte da bibliografia já produzida sobre seu desenvolvimento sócio-espacial, constata-se que a mudança de escala vivenciada atualmente pela cidade, assim como o sentido de sua expansão físicoterritorial, obedece a uma lógica que se estabeleceu desde a chegada dos primeiros habitantes ao município; quando tendencialmente o norte do plano inglês reticulado foi predominantemente ocupado pelas camadas mais populares enquanto o centro e o sul o foram pelas elites. Dadas estas tendências gerais, notadamente formuladas a partir de uma perspectiva histórica que prioriza as variáveis macro e as transformações mais imediatas da paisagem urbana londrinense, nos próximos capítulos procurarei apreender alguns aspectos do atual momento de crescimento de Londrina também no plano da sociabilidade. Para tanto, tomarei como referência a análise do Bar Valentino, que em sua transferência de endereço parece refletir certos aspectos deste processo no âmbito "microscópico" do cotidiano.

\subsection{A "Cena" Artística Londrinense e a História do Bar Valentino}

A partir de alguns trabalhos de cunho historiográfico, sociológico e antropológico realizados no âmbito do lazer, e que de alguma forma se referem aos bares e outros equipamentos urbanos análogos - como cafés e botequins -, observa-se que para além de sua "função comercial manifesta" (MARCELLINO, 2000), expressa na venda de bebidas, estes espaços também possuem algumas "funções latentes" (DUMAZEDIER, 1999), que os tornam importantes suportes de sociabilidade no contexto urbano, como acredito ser o caso do Bar Valentino na cidade de Londrina.

O sociólogo francês Dumazedier $(1976,1999)$ observa, por exemplo, como a partir da Revolução Industrial, quando foi instaurada na Europa uma sociedade predominantemente urbana, o espaço dos cafés tornou-se uma verdadeira instituição em seu país, comportando relações sociais espontâneas e livremente escolhidas. Com base 
em dados estatísticos, o autor argumenta que na França a grande maioria dos indivíduos que procura estes espaços não o faz apenas para o consumo de bebidas, mas, sobretudo, para buscar ali contatos e trocas sociais que ornem, completem ou compensem as relações cotidianas impostas pelo trabalho ou pelos deveres familiares. Além dessas relações, Dumazedier também observa como muitos destes espaços comportam e são especializados em acolher reuniões e manifestações de agrupamentos e associações. Neste caso, afirma o autor, o ambiente dos cafés pode até mesmo ser determinado pelas organizações que comportam, funcionando como locais de propaganda para suas atividades, além de auxiliarem na realização de suas festas e eventos.

No caso brasileiro, o historiador Chalhoub (2001) analisa como os botequins constituíram-se como espaços fundamentais para a resistência política e cultural do proletariado carioca na época em que o Rio de Janeiro experimentava a transição de uma ordem agrário-escravagista para a ordem capitalista, quando se iniciava uma configuração urbano-industrial nas maiores cidades brasileiras. Segundo o autor, um dos fatores que evidencia isso de maneira mais nítida refere-se ao grande contingente de trabalhadores que procurava os botequins para "tomar uma branquinha" ou "jogar conversa fora" durante o expediente, denunciando uma recusa do proletariado carioca ao ideal burguês de separação rígida entre trabalho e lazer na passagem do século XIX para o século XX. Para Chalhoub, neste contexto, era nestes espaços que a grande maioria dos trabalhadores - que não participava de movimentos políticos organizados expressava seus ideais, não a partir da militância, mas através de seus hábitos e costumes cotidianos.

Mais atualmente, e numa perspectiva etnográfica, as pesquisas de Magnani (1998) e Mello (2005), demonstram, respectivamente, como os bares da periferia de São Paulo e os "pés sujos" 17 do Rio de Janeiro comportam uma pluralidade de funções em contextos onde as opções de lazer são escassas e limitadas. Estes autores observam, por

\footnotetext{
${ }^{17}$ Para Mello (2005) os "pés sujos" são aqueles estabelecimentos que apresentam as características que mais se aproximam da idéia do senso comum do que seja um botequim. De maneira geral, essas características referem-se ao ambiente físico (balcão, azulejos, caixa registradora, imagem do santo protetor, cartazes pregando contra o batuque e o fiado); a uma culinária típica, onde o sabor predomina sobre a aparência (feijoada, rabada, angu, dobradinha, variações de contrafilé, costeleta de porco, virado à paulista ); e às relações entre fregueses e funcionários, quase sempre marcadas pelo bom humor e pelas bravatas. Segundo o autor, existem pelo menos duas explicações para o surgimento da metáfora do "pé sujo" para se referir a estes botequins. Uma delas está associada à prática, cada vez menos freqüente, de se jogar serragem ao chão, impregnando a sola dos sapatos dos fregueses com resíduos de pó avermelhado; já a outra se refere à imagem da condição sócio-econômica do freqüentador típico destes espaços: pobre ao ponto de não possuir um calçado.
} 
exemplo, que nas periferias destas cidades tais espaços estão associados tanto às atividades lúdicas (onde se joga partidas de baralho, sinuca, dominó), como às festividades (com as tradicionais rodas de samba, chorinho e serestas) e à troca de informações (sobre futebol, oportunidades de trabalho, notícias da política, dificuldades da vizinhança), funcionando quase que como clubes sociais para seus freqüentadores. Nas palavras de Mello, os botequins, e especialmente os do tipo "pé sujo", são importantes suportes de sociabilidade em contextos normalmente marcados pela exclusão porque "[...] têm a ver com a idéia de vizinhança e proximidade [...] onde reforçamos, sem perceber, a sensação de pertencimento à rua, ao bairro e à cidade" (2005: 31).

Um exemplo mais pontual e muito próximo ao Bar Valentino pode ser encontrado na etnografia realizada por Torres (2000) sobre as práticas de lazer no bairro do Bexiga e na esquina da Avenida Paulista com a Rua da Consolação, na cidade de São Paulo. Em sua pesquisa, a autora cita espaços como o "Café do Bexiga" e o "Bar Riviera", que em sua análise mostram-se como equipamentos de lazer que nas décadas de 1960 e 1970 constituíram-se como importantes suportes para manifestações políticas e culturais em uma conjuntura onde partidos políticos e faculdades encontravam-se sob a pressão do regime militar. Especialmente no que se refere ao "Café do Bexiga", Torres observa que além de ter introduzido em sua região uma proposta "democrática" de lazer - por não instituir a obrigatoriedade do consumo para seus freqüentadores -, este espaço também evitou que "[...] certos valores, certos filmes, certos livros ficassem esquecidos" (2000: 63), em um momento de grande efervescência artística em todo o país.

Dados estes exemplos, o Bar Valentino pode ser considerado como um espaço que ao longo de sua história adquiriu certas "funções latentes" que transcendem os objetivos puramente comerciais normalmente atribuídos aos bares. Em primeiro lugar, desde o seu início lhe foi conferida uma "vocação artística", que o transformou em palco para peças de teatro, musicais, mostras de vídeo, exposições e happenings, levando-o a incorporar a maioria dos artistas londrinenses - músicos, atores, artistas plásticos, cineastas, escritores e poetas. Além disso, por seu "clima" espontâneo, advindo de seus propósitos artísticos, este espaço passou a ser concebido por seus freqüentadores como um "lugar diferente", adquirindo também certas funções associadas ao cotidiano político e sexual de Londrina. Pois, como no exemplo extraído 
da análise realizada por Torres (2000), por seu ambiente considerado "democrático", o Bar Valentino se tornou importante suporte para debates e articulações entre uma parcela da população local no momento em que o Brasil passava pelo processo de abertura política, tornando-se também lócus privilegiado para a manipulação das identidades (homo)sexuais na cidade - sobretudo em uma época em que, pelo surgimento da epidemia de HIV, a sexualidade passou a ser debatida publicamente ${ }^{18}$.

Especialmente pela "vocação artística" que lhe foi atribuída, o Bar Valentino assume ainda mais relevância no contexto local quando se leva em conta que Londrina possui uma efervescência artística fora do comum para os padrões de uma "cidade média", ou de um centro urbano que passa por um processo de metropolização. Afinal, se atualmente a cidade constitui-se como um reconhecido centro produtor e irradiador de artes no país, especialmente no que se refere ao teatro e à dramaturgia, grande parte disso se deve ao Bar Valentino, já que seu espaço sempre manteve uma relação muito íntima com o desenvolvimento destas manifestações. Este fato pode ser confirmado no depoimento de vários artistas que freqüentam ou freqüentaram o bar desde o seu início. Em uma entrevista realizada com o ator e dramaturgo Márcio Américo - que conheceu o Bar Valentino em seus primeiros anos de funcionamento -, por exemplo, é possível observar como na década de 1980 a movimentada "cena" ${ }^{19}$ artística londrinense esteve associada ao bar:

Pra você ter uma idéia, nos anos 80 , teve vezes aqui no festival de teatro, que ainda não era internacional... Que revelou Edson Bueno, que revelou Mário Bortolotto, o Paulinho, que é o Paulo Morais, do [Grupo] Armazén, Adriana Garib, André Luís Lima. Que revelou grandes nomes da dramaturgia, de direção, de interpretação, aqui nesse festival. Então, os festivais, antes de ser internacional, eu me lembro que tinha festival que tinha 30 grupos de Londrina inscritos. Trinta! Você sabe o que é isso? Trinta grupos de teatro com

\footnotetext{
${ }^{18}$ Para autoras como Heilborn (1999) e Loyola (1999), com a epidemia de HIV na década de 1980, a sexualidade, antes associada à intimidade, ao amor e às emoções, passou a ser objeto de cálculos e medidas racionais; socializada e sancionada por um discurso eminentemente público.

${ }^{19}$ Na pesquisa de Bruna Mantese sobre os straight e dges - grupo normalmente formado por jovens, que se originou como uma variante do movimento punk, com o qual compartilham o estilo musical e algo do visual "agressivo", e que têm como principais características a aversão ao consumo de álcool ou drogas, à permissividade sexual e à homofobia, além da adesão ao vegetarianismo, e, em alguns casos, ao veganismo (MAGNANI, 2005) -, o termo "cena" é utilizado como uma categoria analítica. Para Magnani, o termo surge como distensão da categoria circuito. Pois, assim como os "circuitos", as "cenas" supõem um recorte de análise que não se restringe a uma inserção sócio-espacial claramente localizada. Contudo, as "cenas" mostram-se como recortes ainda mais amplos, já que elas denotam, principalmente, "[...] atitudes e opções estéticas e ideológicas, articuladas nos e pelos circuitos”. (MAGNANI, 2005: 201).
} 
espetáculo? Espetáculos próprios. Cada grupo escrevia seu próprio espetáculo! Tanto é, que na época o Mário Prata veio aqui dar uma oficina de dramaturgia e 'ficou de cara'. Ele falou: 'Em nenhuma cidade do Brasil tem tanto dramaturgo assim. Vocês escrevem, vocês mesmo fazem seus espetáculos'. No tempo que ele tava aqui, o Mário [Bortolotto], a cada quatro, cinco meses tava com uma peça nova. Eu também, a cada três, quatro meses, tava com uma peça nova. E isso sem PROMIC, sem 'porra' nenhuma! [...] Você vê a cidade hoje. Hoje em dia têm mais salas do que naquele tempo. Hoje você tem [o teatro] Zaqueu de Mello, você tem o TOU [Teatro Obrigatório Universal], você tem a USINA, o Circo FUNCART, o Ouro Verde. Mas naquela época, com menos salas, mas com o Valentino, e o pessoal se encontrando, era mais produtivo do que hoje, com dez salas na cidade. Porque com esse intercâmbio entre os artistas sempre vai rolar alguma coisa. Porque dois artistas sentam numa mesa de boteco e tem uma cerveja ali no meio e eles vão fazendo planos. Ou é uma mostra, ou é um livro, ou é uma peça, ou é 'alguma merda'. Mas eles vão tá fazendo isso. Porque eu e o Mário, a gente sentava no Valentino, sempre planejando, fazendo planos e planos. Eu tive em Curitiba lançando 'Meninos de Ki-Chute' no ano passado e os caras me perguntaram: 'Como vocês conseguem essa coesão em Londrina? Vocês são muito unidos'. Isso, em grande parte é por causa do bar. (Trecho de entrevista, 13.03.2007).

No depoimento de Márcio Américo, assim como em alguns outros recolhidos durante a pesquisa de campo, a efervescente cena artística londrinense é associada não apenas ao Bar Valentino, mas também ao festival de teatro, ocorrido anualmente em Londrina desde 1968. Para autores como Giorgio (2005) e Marinho (2005), que realizaram pesquisas historiográficas sobre o desenvolvimento das manifestações artísticas na cidade, de fato, o verdadeiro impulso para esta "tradição artística" do município se deu com a realização do I Festival Universitário de Londrina - que reuniu atividades ligadas à música, ao teatro, à literatura e aos Jogos Universitários. Segundo estas análises, a primeira edição deste festival tornou-se marcante, especialmente, pelo fato de que, dada sua condição de cidade recente, esta fora a primeira vez em que os potenciais criativos dispersos nos habitantes de Londrina haviam sido reunidos de forma mais sistemática. Especula-se, então, que foi a partir da realização das primeiras edições dos festivais universitários que o município passou a revelar um espantoso potencial artístico ${ }^{20}$, assim como um público ávido por eventos culturais, que alguns anos mais tarde elegeria o Bar Valentino como seu principal reduto na noite londrinense.

20 Dentre todas as atividades beneficiadas pela realização dos primeiros festivais universitários, certamente o teatro foi a que mais se destacou ao longo das edições posteriores, tornando-se a principal atividade artística do município. Presente de forma ininterrupta desde o I Festival Universitário, o teatro ganhou exclusividade a partir de sua quarta edição, em 1971, constituindo-se como o responsável pela 
Foi neste contexto iniciado pelos festivais universitários, quando Londrina vivenciava uma efervescência artística equiparável aos maiores centros urbanos brasileiros (GIORGIO, 2005) ${ }^{21}$, que, em 1979, foi inaugurado o Bar Valentino. Sua história iniciou-se a partir de uma festa bem sucedida, idealizada por dois professores de um colégio local. Desta mesma iniciativa nasceria também o grupo de teatro "Delta", um dos mais expressivos de Londrina até meados da década de 1980. A festa promovida por Marco Antônio Morais e José Antônio Theodoro, que além de professor e diretor de teatro, também era aficionado pelos filmes mudos estrelados por Rodolfo Valentino, ocorreu no mesmo local onde o bar funcionou até 2006 - uma casa de madeira em uma área que hoje pode ser chamada de "centro expandido" da cidade ${ }^{22}$. Após a festa, que, como afirmam alguns, teve a duração de três dias consecutivos, em sua inauguração efetivamente como bar o espaço já demonstrou sua "vocação artística".

Na fala dos freqüentadores mais antigos percebe-se como essa "vocação" se deu, especialmente, por influência do professor José Antônio Theodoro; como de destaca a seguir, no trecho de uma entrevista realizada com um freqüentador que não quis ser identificado, mas diz ter presenciado a primeira noite do Bar Valentino:

[...] lembro do dia que eu tava assistindo a última aula do período da manhã no Colégio Positivo, em 1979. Eu fazia o primeiro colegial. O professor de História, o José Antônio Theodoro, o Theodoro, no final da aula anunciou a inauguração do bar. Era uma sociedade dele e do professor de Matemática, o Morais. O Theodoro era um incentivador da cultura. Tinha montado o grupo de teatro 'Positivo', que junto com o PROTEU, da UEL, que era dirigido pela professora Nitis Jacon, eram os dois grupos de teatro mais fortes de Londrina e eram referência fora daqui também. O grupo do Theodoro papou ' $\mathrm{N}$ '

evolução do evento - que em 1988 tornou-se internacional, passando a se chamar, desde 1990, "Festival Internacional de Londrina" (FILO) -, hoje considerado como o mais antigo e importante festival independente de teatro do país. Na opinião de sua fundadora, Nitis Jacon, além de ter revelado vários grupos e companhias de teatro londrinenses, o FILO também formou na cidade "[...] um público aberto, exigente e um dos mais importantes do país" (FILO, 2000: 10).

${ }^{21}$ Como afirma Giorgio (2005), no ano de 1973 Londrina recebeu shows importantes, como os de Elis Regina, Chico Buarque e Caetano Veloso, além de ter sediado os festivais "Na Boca do Bode" - como uma espécie de painel musical local, com apresentações de Itamar Assumpção e Arrigo Barnabé, que alguns anos mais tarde levariam para São Paulo um novo conceito musical que passaria a ser conhecido como "Vanguarda Paulista" - e o "Colher de Chá", que contou com nomes como Joelho de Porco e os Mutantes. Para o autor, os eventos musicais realizados durante este ano de 1973 demonstram como, nessa época, Londrina já se mostrava como uma cidade artisticamente efervescente para seus padrões.

${ }^{22}$ Segundo os arquivos do Departamento de Obras e Viação da Prefeitura Municipal de Londrina, a casa de madeira que serviu de suporte ao Bar Valentino foi registrada em 1954, sob propriedade de Maria Lourdes Cezário. 
festivais pelo Brasil e chegou a se apresentar em Nova York. Depois, com a saída de quase todos os professores pra fundar o Colégio Delta, o grupo foi junto e mudou de nome, 'Grupo Delta'. O Theodoro era um excelente professor, apaixonado por História. Tanto é que deixou o curso de Odontologia da UEL no sétimo período, porque na época era o sistema de créditos, pra dar aulas de História. Ele era fã obcecado de cinema. Sabia os nomes de todos os diretores, de todos os filmes. Nas aulas você podia perguntar os nomes de qualquer filme, de qualquer diretor que concorreu ao Oscar, em qualquer categoria, que o cara 'matava na bucha'. Até dos bons filmes que não tinham sido indicados ao Oscar e de filmes não produzidos pelo cinema americano, mas que eram candidatos ao Globo de Ouro, à Palma de Ouro, Leão de Ouro, ele sabia. E eu acho que o bar foi pensando e decorado com esse motivo. Ele também era fã da Marilyn Monroe. O Valentino, no começo, tinha mais de vinte fotos e pôsteres da Marilyn, e tinha também cartazes e pôsteres de outros filmes. Aquele néon, no telhado do bar, é a silhueta de uma personagem do Rodolfo Valentino. Como o professor era, assim, muito ilustrado, é lógico que o bar atraiu a cultura de Londrina. Os poetas, os músicos, os escritores, os artistas, os jornalistas. Todo mundo tava na noite do Valentino. (Trecho de entrevista, 03.12.2006).

Como observa Straviski em seu livro "Pelos Bares do Paraná" ${ }^{23}$, onde o autor reconstitui a história dos bares mais tradicionais do estado, inicialmente o Bar Valentino fora freqüentado quase que exclusivamente por pessoas envolvidas com o mundo artístico, principalmente aquelas ligadas diretamente ao teatro, em um clima "[...] para lá de improvisado e de confiança" (2004: 147). Em seus primeiros anos de funcionamento, por exemplo, o bar literalmente era uma casa, com paredes internas, salas, cozinha e um único banheiro unissex. Os garçons eram os próprios alunos da dupla de professores, que quando não respondiam corretamente as questões colocadas durante as aulas "pagavam prenda" durante a noite, servindo a clientela do bar. Sua freqüentadora mais assídua era uma boneca de pano e cabeça de manequim, chamada

\footnotetext{
${ }^{23}$ O livro "Pelos Bares do Paraná" (2004) foi encomendado pelo Governador Roberto Requião (PMDB, 2003 - 2008), que, em 2005, esteve presente em seu lançamento no Bar Valentino. A obra, que reconstitui uma breve história dos 29 bares mais tradicionais do estado, dedica 12 páginas com fotos e textos sobre este espaço, que também ilustra sua capa e contracapa. Além disso, quase toda a Introdução do livro parece se referir indiretamente ao Bar Valentino, que na época de sua edição já era alvo de fortes rumores sobre sua futura mudança de endereço. Este fato torna-se perceptível quando seu autor escreve, por exemplo, que "[...] um bar tem que estar lá, no lugar onde a gente conhece, ou que nos indicam, sempre que a gente precisa dele. Talvez essa seja a melhor definição para as utilidades cultural, psicológica, terapêutica, além de dezenas de outras à escolha do freguês, que um bar tem de possuir. Não existe maior decepção na vida do que receber a indicação de um lugar maravilhoso, com essas e aquelas atrações e... quando se chega lá... está fechado. No lugar dele há um enorme edifício, estacionamento, casa de massas ou uma boutique de um nouveau riche. [...] Os que constam deste livro são quase todos bares com pelo menos 15 anos e um bom acervo de histórias sobre sua própria existência, salvo uma ou outra exceção justificada. A minha sugestão é a de que eles sejam "tombados" por suas respectivas cidades para que não corram nenhum risco de desaparecimento. Nada mais natural: eles fazem parte da história e também porque ajudam a fazê-la todos os dias" (STRAVISKI, 2004: 6 - 7).
} 
Mary Lee. Todos que passavam pelo Bar Valentino, quando podiam, contribuíam com alguns trocados, que, depositados na cabeça da boneca, eram usados nas ocasiões em que o ambiente ficava mais festivo, para que os clientes bebessem sem pagar. Ainda, havia uma moradora aos fundos da casa de madeira que era adepta do misticismo e aos poucos suas sessões de tarô foram incorporadas ao espaço.

Aproximadamente um ano após a inauguração do Bar Valentino, o grupo de teatro "Delta", liderado por José Antônio Theodoro, fez grande sucesso com a encenação de "Toda Nudez Será Castigada", de Nelson Rodrigues, excursionando com a peça por várias cidades brasileiras e também no exterior. Nascidos da mesma iniciativa, o bar e o grupo de teatro tornaram-se inconciliáveis e o Valentino foi vendido pela primeira vez. Após alguns meses fechado o espaço foi comprado por Giuseppe Loiacono, que ficou conhecido na cidade como "Pino", e sua esposa Consuelo. O casal, formado por um italiano e uma londrinense, havia se conhecido na Europa e desembarcado recentemente no Brasil. Como bom italiano e, conforme afirmam os freqüentadores mais antigos, um excelente cozinheiro, Pino retirou a mesa "17" - que na Itália é considerado um número de azar -, incorporando a tradicional "macarronada da madrugada" ao cardápio do Bar Valentino, até então composto por sanduíches e drinks batizados com nomes clássicos do cinema, como Humphrey Bogart, Alfred Hitchcock, Marilyn Monroe e Rita Hayworth.

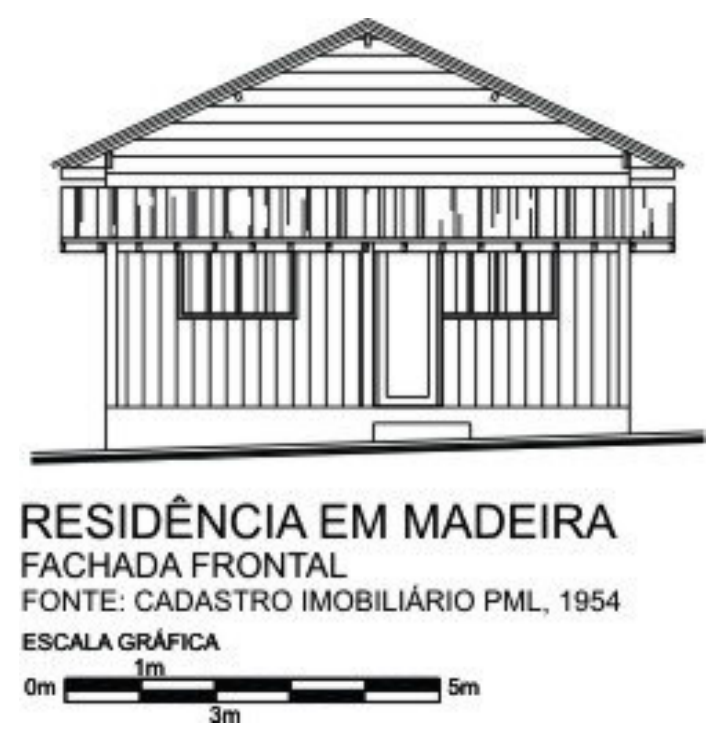

Ilustração 1. Fachada frontal da casa de madeira (1954) que serviu de suporte ao Bar Valentino até 2006 (Anterior às reformas).

Fonte: Reciclagem e Preservação do Patrimônio Edificado (CD-ROM, 2007). 


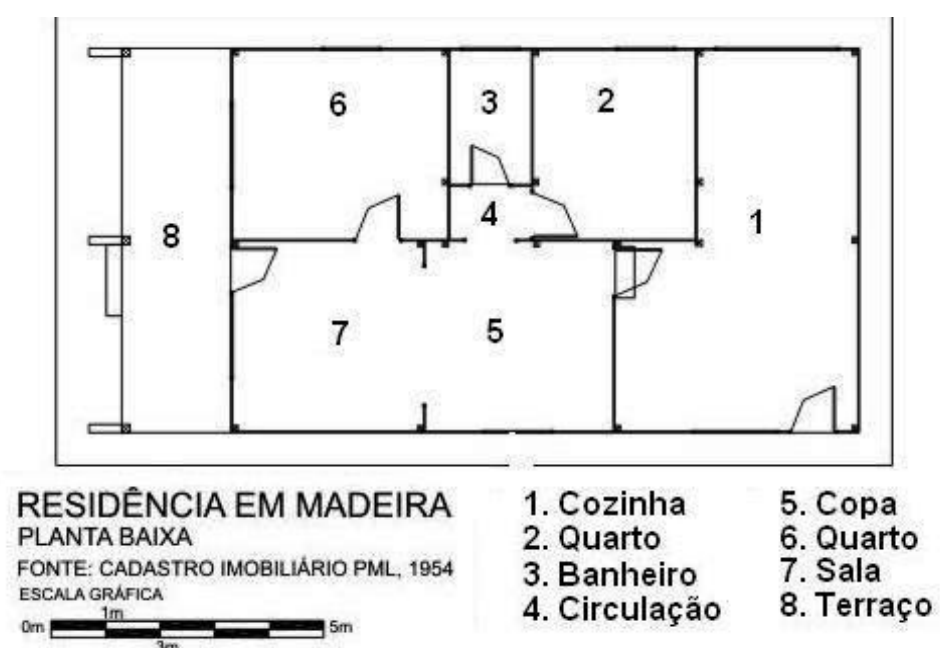

\section{Ilustração 2. Planta baixa da casa de madeira (1954) que serviu de suporte ao Bar Valentino até 2006 (Anterior às reformas). \\ Fonte: Reciclagem e Preservação do Patrimônio Edificado (CD-ROM, 2007).}

Em 1984, com a separação do casal, Pino tornou-se sócio do engenheiro Jaime Rocha Júnior, conhecido como "Jaiminho", responsável pelas primeiras reformas no ambiente, que deram à casa de madeira alguns aspectos semelhantes a um $p u b^{24}$. Dentre as modificações ocorridas no espaço físico, nessa época houve a retirada das paredes internas, assim como a construção de novos banheiros, agora divididos por gênero, e a criação de uma varanda lateral externa. A partir destas reformas, que dotaram o Bar Valentino de uma atmosfera um pouco menos "improvisada", o espaço passou a comportar um público mais amplo, mas ainda assim ligado aos setores mais "intelectualizados" da população - como políticos, jornalistas, professores e estudantes universitários. Nas palavras de seu ex-proprietário, Jaiminho:

[...] eu era amigo do Pino e freqüentava o bar lá. Tomava meus aperitivos e tudo. E papo vai, papo vem, o Pino me falou: 'Olha Jaime, eu tô querendo vender o bar. Você quer comprar?'. E eu falei: 'Eu não'. Porque pô! Eu sou engenheiro civil, nunca tive bar e tal. E ele falou: 'Eu queria ou vender, ou arrumar um sócio'. Acho que ele me falou isso aí uma vez, e uns 15, 20 dias depois eu falei: 'Pô! Eu podia comprar, ficar sócio do bar'. Só que o bar realmente era uma

\footnotetext{
${ }^{24}$ São conhecidos por pubs os bares característicos a alguns países europeus - especialmente, a Inglaterra e a Irlanda -, que têm como traços distintivos uma arquitetura rústica, normalmente executada em madeira; a iluminação baixa, à meia luz; o ambiente informal e descontraído; a presença de jogos, como snooker e dardos; o consumo de bebidas no balcão; e, em alguns casos, as apresentações de bandas musicais. A origem do termo pub é atribuída à abreviação da expressão public place, que traduzida do inglês significa "lugar público" (http://www.pubs.com/pub_history.cfm).
} 
casa, a divisória era a de uma casa. Tinha um banheiro interno, que era um banheiro unissex na época. Quer dizer, um banheiro só pra homem e mulheres. Tinha um quarto no fundo, um quarto na frente e a sala. Onde era a cozinha era a cozinha mesmo. Então era uma casa dividida. Aí conversamos. Eu tava tomando um aperitivo com ele depois de um mês, não sei. Eu falei: 'Olha Pino, quanto é que você quer?'. Pediu uns $6.000 \mathrm{R} \$$, alguma coisa assim. Na época não era nem reais, era outro valor. Eu falei: 'Olha, eu tenho esse dinheiro pra ficar sócio. Só que eu acho que a gente podia transformar, melhorar o bar'. Porque o barzinho era muito gostoso, aconchegante e tudo. Só que era uma casa dividida. Tinha que fazer um banheiro lateral, masculino e feminino, melhorar a cozinha... E ele topou. E eu fiquei sócio dele. Aí ele foi viajar, e eu sou engenheiro, né? Daí eu entrei, arranquei as paredes todas, fiz dois banheiros, fiz uma cozinha nova. Aquela varanda lateral... Aquela varanda frontal já existia, eu repeti a varanda lateral com o mesmo design que tinha na varandinha da frente, inclinado e tudo. Reformamos o bar e aí foi um sucesso. Porque aí ampliou e começou uma loucura toda, porque aí teve teatro ao vivo. Teve uma série de coisas. Teve lançamento. O Paulo Leminski, que é um escritor que já faleceu, veio lançar livro. Veio alguns cartunistas de São Paulo, Glauco, Angeli. Veio acho que o Roberto Freyre pra lançar livro, a Alice Ruiz, esposa do Leminski. Então ele virou um bar cultural, porque passou a ir, na verdade, muita gente da universidade, que eram professores e alunos. Fora que ia os políticos também. (Trecho de entrevista, 29.01.2008).

Como é possível perceber no depoimento de Jaiminho, além das referidas reformas, a relativa ampliação do público do Bar Valentino nessa época também se deu pela realização das primeiras apresentações artísticas, que, de certa forma, ainda ocorriam de maneira espontânea, já que não havia um calendário de eventos regular. Outro fator destacado em alguns dos depoimentos recolhidos refere-se a uma prática iniciada pelo grupo PROTEU (Projeto de Teatro Experimental Universitário), que passou a se reunir no local após os seus ensaios e espetáculos, iniciando certa "tradição" entre os diversos grupos de teatro e apreciadores de artes na cidade. Ao lado do Delta, o PROTEU - fundado por Nitis Jacon, idealizadora do FILO - era considerado como o grupo mais importante de Londrina, especialmente, por ter montado peças "corajosas" e “escandalosas” em plena repressão - como "Calabar", de Chico Buarque, em 1979, e "Salto Alto", de Mário Prata, em 1983. Alguns freqüentadores também concordam que este grupo foi responsável pelo primeiro evento de maior porte realizado no Bar Valentino, com a encenação da peça "Barba Azul", idealizada especialmente para o espaço. 
Em outro trecho da entrevista realizada com Márcio Américo, o entrevistado ressalta não apenas a importância do grupo PROTEU para a consolidação do Bar Valentino como um "bar cultural", como também as discussões de cunho político ocorridas no espaço:

Nos anos 80 começou a parecer em Londrina... O Valentino eu não tenho certeza se foi um dos primeiros, mas eram casas de madeira transformadas em bar. Pegavam essas casas de madeira e transformavam em bar. Então, tinha o Lumiar, tinha o Chaplin. Tinha uns 10 ou 15. 'Neguinho' pegava, alugava casa de madeira e virava bar. E o Valentino foi o que mais se destacou, talvez... Talvez não. Com certeza, porque foi o bar adotado pelo grupo PROTEU, que nos anos 80 era o grupo da moda, o grupo de resistência. Que montava as peças que tinha um discurso de esquerda, que era o que se esperava no começo dos anos 80. Tinha o PROTEU e o Delta. O Delta era um grupo de elite, que montava espetáculos inofensivos, plásticos, cenicamente bonitos. Quer dizer, as pessoas engajadas ficavam com o PROTEU. E o PROTEU freqüentava o Bar Valentino. Foi a partir desse momento, que PROTEU começa a freqüentar o Bar Valentino, que ele começa a atrair pessoas pra lá. Porque eles terminavam o espetáculo e falavam: 'Valeu rapaziada! Agora vamos pro Valentino tomar cerveja!'. Aí todo mundo seguia o PROTEU e ia pro Valentino. Porque quando tinham os festivais universitários, que depois virou Festival de Teatro Amador, e depois essa 'porra' desse FILO, os grupos vinham em peso pra cá. Do Paraná, outros estados do Brasil. E após a última peça, como o PROTEU ia pro Valentino, esses grupos seguiam. Então, começou a encher de grupo de teatro. E o quê as pessoas discutiam ali dentro? O último espetáculo da noite, o festival, a repressão que tava diminuindo, a agonia do regime militar. E tudo isso foi fortalecendo uma cara de bar cultural. Aí, nessa época já tinha show no festival, algum convidado. João das Neves, Alceu Valença, Aderbal Júnior, Paulo Autran, iam tudo lá pro Valentino. Aí o quê acontece? Essas pessoas todas freqüentando o bar, pessoas ligadas à arte e à área de cultura. Isso atraia, né? Os poetas iam lá, os escritores iam lá. Depois foi abrindo pra banda, pra performance. Mas quando eu falo do PROTEU, que ele capitaneou essa manada de gente pro Valentino, não é à toa. Porque quando foi montado não sei qual espetáculo, que era muito bonito, em uma das cenas uma menina tá fazendo uma banca pra ator. E no texto... Acho que era o 'Auto da Compadecida'. Ela tava fazendo a banca lá pro 'Auto da Compadecida', e a voz de Deus quem fazia era o Pino [proprietário] do Valentino. A voz de Jesus, na verdade: 'Me chamam de não sei o quê, mas você, se quiser, pode me chamar de Jesus', com aquele sotaque arrastado de italiano. Aí a menina fala assim: 'Que Jesus o quê! Você é o Pino lá do Valentino. Eu conheço você, eu não saio de lá'. Sabe? Jogar esse lance no meio da peça era uma 'puta' propaganda. Quem não sabia, queria saber: 'que porra é o Valentino?'. (Trecho de entrevista, 13.03.2007). 
No depoimento de Jaiminho, proprietário do espaço na época, também é possível perceber a importância do grupo PROTEU para o início dos eventos artísticos, assim como para a intensificação da presença do público no Bar Valentino:

O pessoal do teatro ia todo dia no bar. Então, eles [o grupo PROTEU] acabaram fazendo uma peça que estreou no bar, que chamava 'Barba Azul'. Depois parece que teve outra peça, não lembro. Mas o 'Barba Azul' foi uma peça feita pelo grupo PROTEU, que é esse grupo que existe até hoje. Esse grupo deve ter uns 30 anos, ou mais. Que a Nitis [Jacon] era a diretora. Então, eles fizeram uma peça e apresentaram no bar. E foi uma sensação, entendeu? E depois essa peça acabou indo pra Curitiba, pra São Paulo. Eles foram pra bares em Curitiba. Porque foi uma peça feita 'para o bar'. Então, na verdade teve uma coisa anteriormente e depois esse segmento foi o Pino que fez questão. Falou: 'Jaime, vamos começar a convidar isso?'. E eu falei: 'Vamo embora!'. Então, ele teve essa parte que foi muito grande mesmo. Porque nos anos que eu fiquei sócio dele teve diversas coisas. Na época, os bares normais aqui não faziam isso, entendeu? Aí depois teve shows, como têm até hoje. Um show ao vivo, um som. Porque o som era mecânico. Depois teve pessoas declamando poema, essas coisas começaram a acontecer. Aconteceu bastante. Muitos bares fechavam meia-noite, uma hora. Aí começou a acontecer que sexta, sábado a gente começou a fechar seis, sete horas da manhã, clareando o dia. Na verdade, todos esses eventos que teve lá... Simplesmente ficava lotado! E teve alguns dos eventos que teve que fechar a porta, porque não cabia mais gente. No teatro aconteceu isso. Essa peça de teatro foi apresentada diversas vezes. Na primeira vez já lotou, na segunda vez que ela foi apresentada ficou pra fora 80,100 pessoas. Porque não dava mais pra entrar. Porque era uma peça que o pessoal utilizava diversas partes do bar e o pessoal tinha que ficar sentados nas mesas, ou encostado, né? (Trecho de entrevista, 29.01.2008).

Com o retorno de Pino para a Itália em 1986, o espaço foi novamente vendido. Desta vez, fora oferecido a Marcos Henrique Marangoni, proprietário de uma casa de massas que era fornecedora do Bar Valentino desde a sua primeira venda, por volta de 1981. Afora a incorporação da varanda lateral à área interna do bar - que, por sua inclinação, propositalmente dava uma sensação de vertigem aos que passavam por ali -, Marcos não promoveu transformações expressivas em sua estrutura física, apesar de ter adotado certos procedimentos curiosos, como alguns pontos de luz constituídos a partir de lâmpadas de aquário e a decoração dos banheiros com gravuras da Valentina, a sensual personagem das histórias em quadrinhos italianas. Contudo, uma mudança significativa nessa época foi a afixação de um calendário artístico regular, com ampla divulgação dos eventos por toda a cidade. Desde então, o Bar Valentino, freqüentado 
pelas camadas mais "intelectualizadas", passou a ser procurado por diversos grupos sociais, tornando-se um dos points ${ }^{25}$ mais movimentados da noite londrinense.

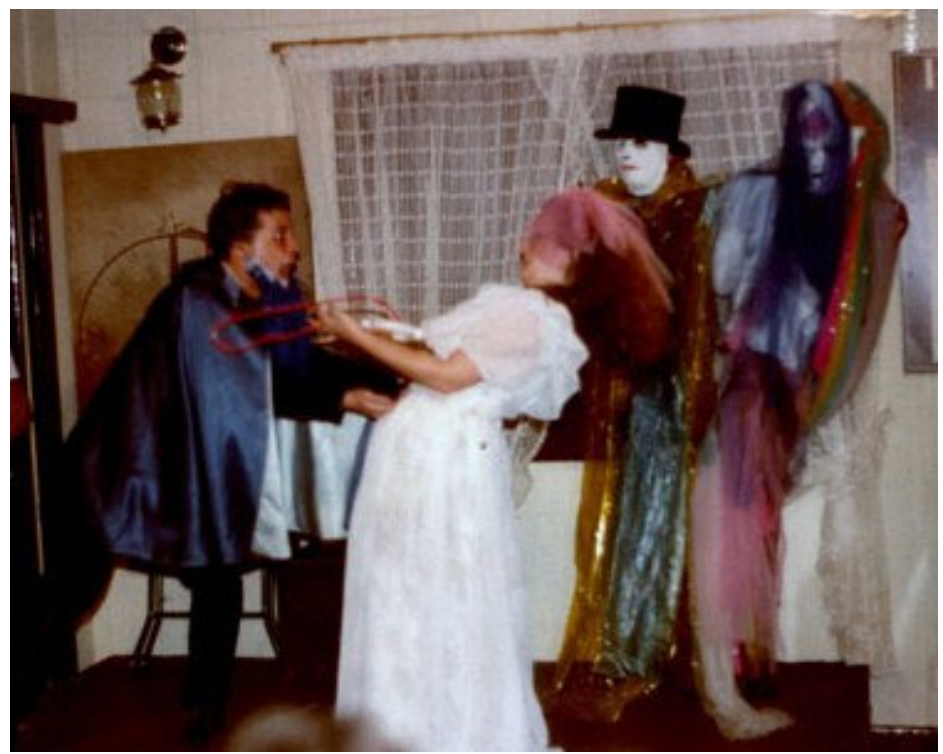

Foto 3. Apresentação da peça "Barba Azul" com o Grupo PROTEU (1985). Fonte: Acervo fotográfico do Festival Internacional de Londrina (FILO).

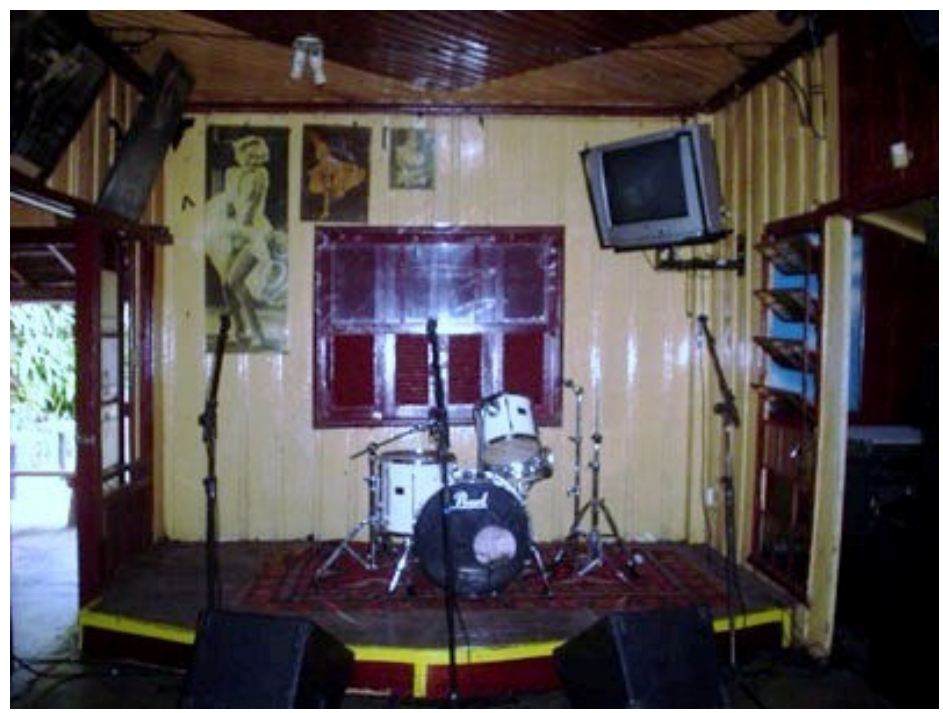

Foto 4. Palco do Bar Valentino à luz do dia (2004). Fonte: Acervo pessoal do autor.

\footnotetext{
${ }^{25}$ Como afirma Magnani (2005), o termo "point" mostra-se presente em diversas etnografias urbanas. Contudo, apesar da diversidade de grupos que utilizam o termo em seus discursos, seu sentido é recorrente, sempre se referindo a "[...] um único equipamento, geralmente de grande porte e ocupado por vários grupos, servindo como 'enlace' entre eles”. (2005: 201).
} 
Mas ao mesmo passo em que a "profissionalização" dos eventos e a conseqüente ampliação do público transformaram o Bar Valentino em um dos espaços mais procurados nas madrugadas da cidade, isso também implicou na incorporação de algumas medidas por parte de seu proprietário - como o fechamento aos sábados e a presença de policiais à paisana - visando, sobretudo, conter o sensível aumento no uso de drogas por parte de alguns dos freqüentadores. Pois, segundo Marcos Marangoni, o relativo anonimato proporcionado pelo grande número de pessoas que passou a se dirigir ao bar facilitou a ação dos usuários. No depoimento concedido pelo exproprietário é possível constatar que estas medidas não se deram, por exemplo, em função da violência, mas especificamente à inibição do uso de drogas, que anos mais tarde tornou-se um dos fatores responsáveis para a transferência do Bar Valentino.

As pessoas pra quem eu dei a chave do bar, elas iam ensaiar. Elas comiam, bebiam e colocavam tudo em cima lá, o que eles tinham tomado. Então, eu nunca tive problema de alguém estragar alguma coisa minha. Ladrão, em seis, cinco anos lá eu nunca tive problema com ladrão. Teve, assim, alguma tentativa de arrombar, mas prejuízo, efetivamente, eu nunca tive. Mas eu tinha, na época, um combinado com os policiais federais. Porque eu dei aula de Educação Física muito tempo, pra muitos policiais federais e foi bem... Criou uma amizade, sabe? Eu fui professor de Educação Física, então eu sempre preconizei a saúde, pra muita coisa. E droga, obviamente, não faz parte do meu conceito. E eu sabia de amigo que usava, mas eu cuido da minha vida e você cuida sua. Mas eu era exemplo ali, então eu tinha que preconizar uma certa postura. Então, na época tinha... Porque a gente pagava o ECADE, e tinha que pagar uma grana pra Polícia Federal. Então, eu, além dos que eu tinha conhecido quando eu dava aula de Educação Física, eu passei a conhecer os outros lá dentro. E ficamos amigos. A gente conversava bastante. E eu passei a pedir pra esses policiais federais, pra quando eles fossem fazer alguma atividade na rua à noite, que era pra passar no bar e jantar comigo, que o macarrão ia ser por minha conta. Eles passaram a ir. E quando eles iam, eu falava pros garçons avisar as pessoas: 'ó, eles tão aqui perguntando pra mim quem é que mexe com droga'. Mas era mentira, eu que criei essa situação. Então, eu não vou 'dedar', mas se ele perguntar eu também não vou mentir. Se eu não ver eu não sei. Mas se eu ver eu vou ter que falar. Então, eles iam lá e eu falava pro garçom: 'ó, os caras tão aí, se eu ver eu vou ter que entregar'. Aí ficou aquele: 'não deixa o Marco ver, porque se ele ver, se acontecer alguma coisa, ele vai entregar'. Mas aí chegou uma época que no sábado era tão terrível e que não era financeiramente interessante. Teve uma época que eu fechei de segunda e de sábado. Porque não dava. Ou era confusão, ou era só bêbado. Lotava demais e financeiramente não era legal. Então eu fechei de sábado uma época, mas depois voltou a abrir. Às vezes eu sonho, sonho à noite que ainda sou dono de bar, que a Rosângela [Chammé. Que posteriormente tornou-se proprietária] tá 
me devolvendo... Que eu vou pro bar trabalhar. É comum eu sonhar isso. Mas não é legal não. Quando eu sonho, eu penso: 'que bom que não é mais assim'. (Trecho de entrevista, 20.03.2007).

Dada esta situação, classificada em seu depoimento como "terrível”, em 1991, Marcos Marangoni vendeu o Bar Valentino aos seus atuais proprietários Waldomiro e Rosângela Chammé, que posteriormente passaram a contar com mais dois sócios: Márcio Guerra e Ismael Motta, conhecido entre os freqüentadores como Preá. Nas mãos dos novos sócios, em 1998, algumas reformas modificaram um pouco mais o ambiente a fim de atender as novas necessidades do espaço. $\mathrm{O}$ assoalho, em madeira, que estava por ruir e balançava muito durante os shows de rock, foi substituído por cimento, enquanto que o balcão foi ampliado e reposicionado, facilitando os pedidos dos clientes. Já na parte externa, mesas fixas de concreto foram implantadas e o jardim fora todo reformulado. Outras modificações foram realizadas visando a própria segurança do ambiente, já que agora passavam pelo Bar Valentino dezenas, centenas, de pessoas todas as noites. Por exemplo, parte das varandas foi desmontada, as janelas ganharam grades e as regras ficaram um pouco mais rígidas - a partir de certa hora da madrugada não se entrava mais no bar. Na opinião de Chammé, a reforma foi "a mais sutil possível”, para que o espaço não perdesse sua identidade; mas ainda assim as transformações parecem ter sido polêmicas, uma vez que, segundo Straviski, “[...] os 'dinossauros' aprovaram as mudanças e os jovens universitários protestaram, achando que a tradição estava sendo corrompida" (2004: 149).

Outra mudança importante dessa época mais recente se deu em 2002, quando a incorporação de Disc-Jockeys (DJs) em algumas ocasiões, implicou na diversificação musical do espaço - antes limitada quase que exclusivamente ao jazz e ao blues - e na criação de algumas "noites temáticas". Nestas ocasiões, o bar, em alguns dias e até determinado horário, passou a ser procurado por públicos mais específicos, sobretudo, por conta da seleção musical. A "Raw Power" e a "Terça Tilt", por exemplo, eram noites embaladas, respectivamente, pelos clássicos do punk rock ou do glam rock e do "rock alternativo", aglutinando predominantemente certos grupos que compartilhavam de preferências musicais semelhantes; no caso, as diferentes vertentes do rock - como punks, darks, rockabyillis, mods e "alternativos". Já nas noites "Valentino Eletrônico", "Noite Latina", e "Noite do Charuto Cubano", como seus próprios nomes sugerem, prevaleciam respectivamente as tendências musicais eletrônicas e os ritmos latinos. 
Neste caso, a "seleção musical" aparecia apenas como uma variante indireta, uma vez que a lógica de aglutinação se dava em torno da "sexualidade". Pois, nestas ocasiões, o público não era formado necessariamente por apreciadores de música eletrônica ou de ritmos latinos, mas predominantemente por grupos de alguma forma ligados ao universo GLBTT (Gays, Lésbicas, Bissexuais, Travestis e Transgêneros), que, pela sensualidade mais aflorada despertada por estes ritmos, encontravam nestas noites temáticas mais possibilidades de paquera e aproximação de seus pares do que na "Raw Power", por exemplo.
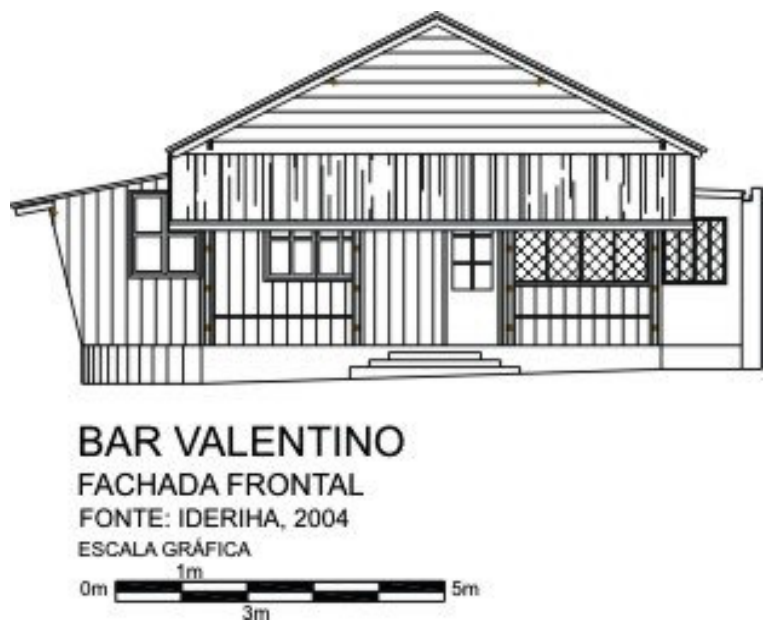

Ilustração 3. Fachada frontal do Bar Valentino (2004) após as reformas. Fonte: Reciclagem e Preservação do Patrimônio Edificado (CD-ROM, 2007).

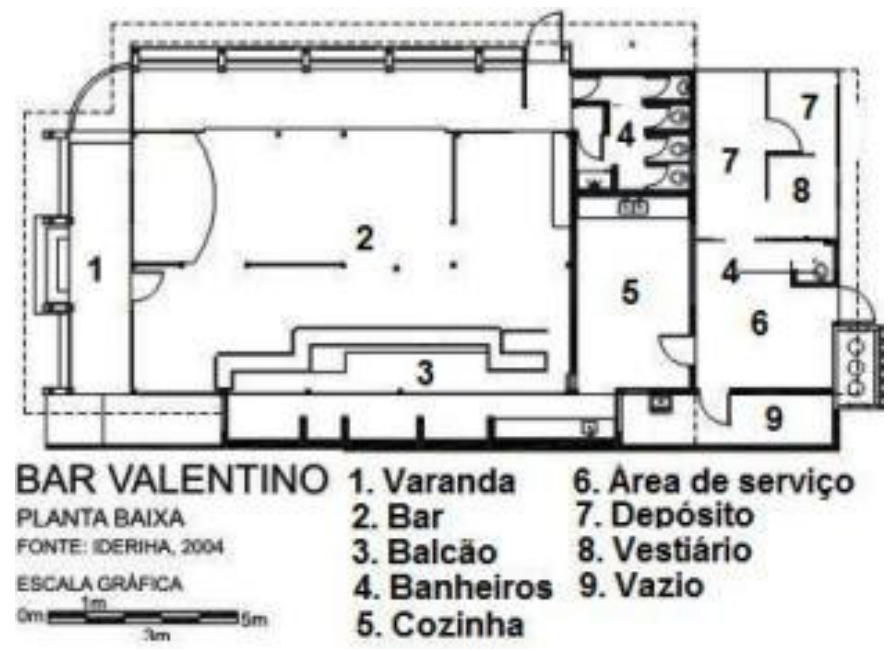

Ilustração 4. Planta baixa do Bar Valentino (2004) após as reformas. Fonte: Reciclagem e Preservação do Patrimônio Edificado (CD-ROM, 2007). 
Contudo, apesar de certa segmentação do público em determinados dias e horários, mais recentemente a diversidade de seus freqüentadores, ao lado da "vocação artística" que lhe foi atribuída já em sua inauguração, continuou a ser uma das características mais marcantes do Bar Valentino. No trecho a seguir, retirado de uma entrevista com Waldomiro Chammé - realizada em 2004, quando o espaço ainda estava localizado no centro da cidade - torna-se perceptível a grande rotatividade e a heterogeneidade do público ao longo das noites, dos dias da semana e no decorrer do ano. São notáveis também os diversos agrupamentos de jovens citados pelo proprietário, como o pessoal GLBTT, rockabyllis, punks, "metaleiros" e hippies:

T: Você conseguiria mapear, durante a semana, como é a dinâmica? A freqüência do público durante a semana?

V: O que eu acho mais interessante aqui é a sintonia que a gente tem termos de som. Porque o som do Valentino é bom, sabe? Porque eu conheço bastante lugar diferente e, assim, eu acho difícil ter uma diversidade com a qualidade que tem o bar. Porque a gente vai guardando o que tem. Não vai descartando tudo, né? Então eu acho que o som une bastante as pessoas aqui. Então, nos dias que tem show aqui, que são quartas, quintas e domingos, a frequiência vai depender muito de quem vai tocar. Por exemplo, se numa quinta-feira é o "Cherry Bomb" [punk rock] é um público que gosta deles. Se é uma coisa, assim, de música mais brasileira, aí já vai dar uma variada. Mas isso é só no começo da noite, até meia-noite mais ou menos. Porque hoje em dia a gente é obrigado, por causa da lei do silêncio, a ter evento só até às 23 horas. Então, até 23 h 15 , onze e meia, tal, tá aquele público mais ligado aquele evento. Depois já começa uma mistureira. Assim, já começa a entrar gente de outro lugar e sair, e aquele pessoal do evento também vai embora e tal. Começa a misturar. Por exemplo, o pessoal da "Terça Tilt" é um pessoal mais ligado em som, que você vê que eles são amigos fora daqui, sabe? Você vê que eles têm uma identidade. Então, tem muito essa questão da freqüência variar. Sexta e sábado tem uma dinâmica do começo pro fim da noite, né? Tem os gays que chegam pra fazer point antes de ir pras festas deles mesmo, né? Que é entre as $11 \mathrm{~h} 30$ e a meia-noite, mais ou menos. Tem também os casaizinhos, que sempre chegam no começo da noite. São os que chegam mais cedo, assim, pra jantar. Um clima bem romântico no bar. Fica bem legal. E eu falo casaizinhos, mas não é só de vinte, dezoito anos. Tem de quarenta, às vezes de cinqüenta também. E tem os 'dinossauros' do Valentino, só que eles vêm aqui com menos frequiência. $\mathrm{E}$ também não vêm naqueles dias mais de doideira, tipo sábado de madrugada, que é 'rockão' alto, né? $\mathrm{O}$ que é muito inusitado é que às vezes eles encontram os filhos, sabe? Tem, por exemplo, os rockabillys. Eles chegam sempre num determinado horário, depois de já ter ido a outros lugares. Eles têm um padrão, assim, de não sentar. Então eles chegam e ficam tudo no corredor. Eles têm uma característica física parecida, o cabelo parecido. As roupas e tal. Ah, e tem o pessoal que gosta de 'metal', tipo heavy 
metal. Eles também são bem característicos, têm uma maneira de ser. Os punks também, que andam em tribo. Tinha um pessoal da UEL, meio hippie, sempre a mesma turma, que vinha muito aqui em fim de noite. Eu não gostava, porque eles ficavam aqui na varanda, fazendo o som deles aqui, com violão, de madrugada. Então, horário do pessoal do prédio [vizinho] ligar. Aí eu falava com eles e eles iam lá na Avenida [Bandeirantes] e continuavam tocando lá. Então às vezes acontece isso. Mas é muito identificado, assim, as tribos. O jeito delas se comportar. Ou mesmo que não seja uma tribo do ponto de vista estético ou cultural, mas que seja grupo de amigos que tenha uma certa característica. Ou por serem barulhentos, ou por gostarem de um certo tipo de coisa. Tem gente que vem aqui só pra comer, tipo, quatro horas da madrugada, sabe? Eu acho até que é a diversidade que faz o bar. Então varia muito de dia pra dia, varia do começo pro fim da noite. E época do ano também. Em junho, julho é sensacional! Porque vem o pessoal do Festival de Música, gente do Brasil inteiro. Na época do FILO também é muito interessante, porque vêm muitos estrangeiros e aí os londrinenses fica, de alguma forma, também querendo vir ao valentino. Então ele varia também conforme a época do ano. (Trecho de entrevista, 26.10.2004).

Outra característica historicamente atribuída ao Bar Valentino é que em meio à grande heterogeneidade de seu público, o espaço tornou-se um ponto de encontro GLBTT, levando alguns de seus freqüentadores a lhe imprimirem o status de "bar gay". Este foi o tema da pesquisa de Iniciação Científica que realizei ali entre meados de 2004 e o final de 2005 (MEIRA, 2005), quando me propus a analisar as concepções e representações acerca das identidades (homo)sexuais construídas por seus freqüentadores. De maneira geral, nesta ocasião, pude concluir que a parcela de seus usuários que, de alguma forma, era ligada ao universo GLBTT encontrava neste espaço uma forma de exercitar os códigos associados as suas (homo)sexualidades que não lhe era permitida em outras esferas socializantes - como a família, o trabalho, a escola e a faculdade. Afinal, pela "atmosfera artística" característica ao Bar Valentino, ali os símbolos construídos em torno das (homo)sexualidades adquiriam um caráter polissêmico, associado aos aspectos mais valorizados do que estigmatizados do estilo de vida GLBTT, como a "espontaneidade", a "alegria", a "sensibilidade", a "diversidade estética" e a "relação com as artes". Ou seja, enquanto alguns de seus freqüentadores eram vistos no cotidiano como "gayzinhos", "veados", "sapatões" e "bizarros", no Bar Valentino eles eram percebidos enquanto "cults", "intelectuais", "cabeças abertas", "espontâneos" e "artistas", lhes permitindo tornar pública suas identidades (homo)sexuais. 
Mediante estas últimas considerações, é notável que - apesar da sucessão de proprietários e de algumas transformações ao longo do tempo - mais recentemente o Bar Valentino ainda comportasse interações sociais relativamente espontâneas, principalmente, quando comparado a outros espaços da cidade. A partir de seu histórico, constata-se também que além de nunca ter abandonado seus propósitos artísticos, tornando-se um espaço de grande importância para a projeção de Londrina no cenário artístico nacional e internacional, o bar, que em seus primeiros anos teve sua freqüentação mais restrita às camadas "intelectualizadas", transformou-se em um dos pontos de encontro mais movimentados da cidade. Pelas "funções latentes" que adquiriu ao longo do tempo, mais do que um "simples" bar, o Valentino tornou-se um importante suporte de sociabilidade para grupos diversos e heterogêneos, que encontravam ali possibilidades para exercerem mais abertamente seus interesses associados às artes, à política, às drogas, à sexualidade ou aos (im)previsíveis encontros proporcionados pelo cotidiano.

\subsection{O Bar Valentino e os Circuitos no Centro}

\subsubsection{Bar Valentino: "Para Quem Está In, Out, Up and Down"}

No período em que permaneceu na região central de Londrina, o Bar Valentino esteve localizado em uma área circunscrita entre as avenidas Bandeirantes e Juscelino Kubitschek, as ruas Jorge Velho e Prof. João Cândido e a Alameda Júlio de Mesquita Filho. O motorista ou transeunte mais distraído que à luz do dia cruzava a Avenida Bandeirantes na altura do bar, mal o reparava em meio às clínicas médicas e aos estabelecimentos comerciais que funcionavam ao seu redor. No entanto, ao anoitecer, por volta das 20h, quando os equipamentos do entorno já haviam fechado suas portas, o espaço começava a se destacar na paisagem. A luz avermelhada que irradiava de seu letreiro ao estilo néon, com a silhueta de um dos personagens de Rodolfo Valentino e a réplica da assinatura do ator, de longe chamava a atenção. Já por volta das $22 \mathrm{~h}, 23 \mathrm{~h}$, pelo ritmo lento dos automóveis à procura de estacionamento e pelas galeras que 
começavam a se aglomerar na calçada do bar, era impossível não notá-lo diante da relativa calmaria nas ruas mais próximas.

Para quem chegava ao Bar Valentino pela Avenida Bandeirantes, os primeiros a serem avistados eram alguns "flanelinhas", sempre em pequenos grupos, em meio aos automóveis estacionados. Nesta época, entre 2004 e 2005, não era raro que alguns deles oferecessem drogas, especialmente maconha e cocaína, aos que se aproximavam. Já para os que chegavam pela Rua Jorge Velho, o primeiro contato visual - ainda na calçada, alguns metros distante do bar - se dava com algumas "funções" de "manos" 26 , quase sempre encostados nos carros, conversando ou ouvindo rap, ou em "rodinhas", por vezes fumando um "baseado" na fachada de alguma clínica. Nem todos que chegavam ao bar notavam o ato ilícito, e os que percebiam não pareciam se importar muito. Por este fato, sobretudo aos finais de semana, era comum a presença de uma viatura policial parada em frente ao Bar Valentino, além de uma dupla de seguranças no portão. Nas noites de maior movimento, a aglomeração era grande, obrigando os seguranças a restringir a entrada no bar até que determinado número de pessoas saísse dali.

Os que chegavam, antes de adentrarem ao que outrora foi uma tradicional casa de madeira, obrigatoriamente deviam passar pelo ambiente externo, disposto na forma aproximada de um semicírculo. A área externa contava com alguns canteiros, bem cuidados, além de algumas mesas fixas, construídas em concreto. Aos finais de semana, quando o bar recebia um número maior de frequientadores, eram acrescentadas algumas outras mesas e cadeiras, de ferro, que traziam estampadas a logomarca da cerveja que patrocinava o espaço. Estas mesas eram distribuídas de modo a formar um corredor, ou um vão livre, entre o portão do bar e a porta do ambiente que os freqüentadores convencionaram a chamar de "casinha". As mesas nunca eram suficientes para a quantidade de usuários e a maioria das pessoas permanecia em pé, mas sempre contando com a solidariedade dos "donos" das mesas para apoiar seus copos e garrafas de cerveja. Ainda na parte externa, mas em um nível um pouco mais alto, havia uma varanda com mesas e bancos, agora em madeira. O acesso à varanda se dava por meio de três degraus que, como se tivessem vida, algumas vezes eram xingados pelos tombos que proporcionavam aos freqüentadores. Dali se tinha uma visão privilegiada da área

\footnotetext{
26 "Mano" é uma categoria nativa muito utilizada pela maioria dos freqüentadores do Bar Valentino para designar de modo pejorativo os usuários provenientes das periferias da cidade. Isso será mais bem discutido no terceiro tópico deste Capítulo, "2..3 Os Últimos Anos no Centro".
} 
externa do bar, e por isso, ali permaneciam aqueles que estavam "caçando" alguém em meio à multidão. Pelos muros baixos, desta varanda também era possível avistar o que se passava na rua. Via-se quem estava chegando e quem estava indo embora. Afinal, o Bar Valentino era local de passagem para alguns e de permanência para outros.

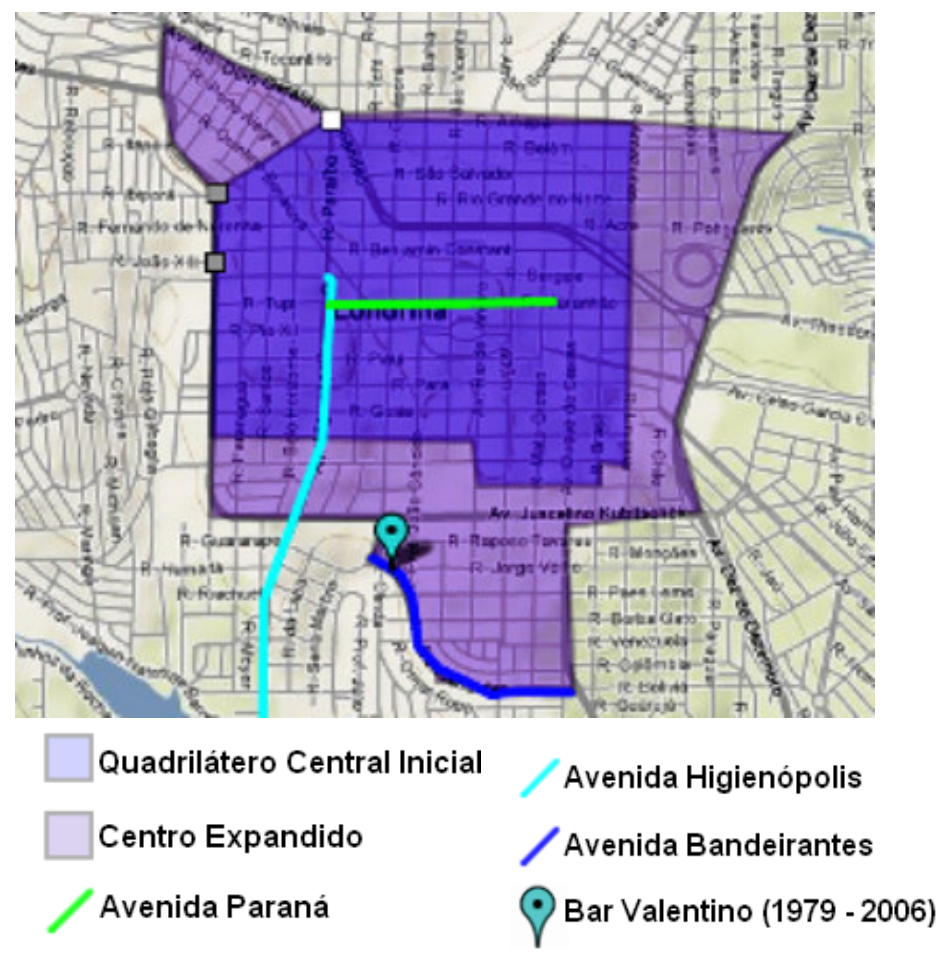

Mapa 7. Localização do Bar Valentino (1979 - 2006). Fonte: www.google.maps; editado pelo autor.

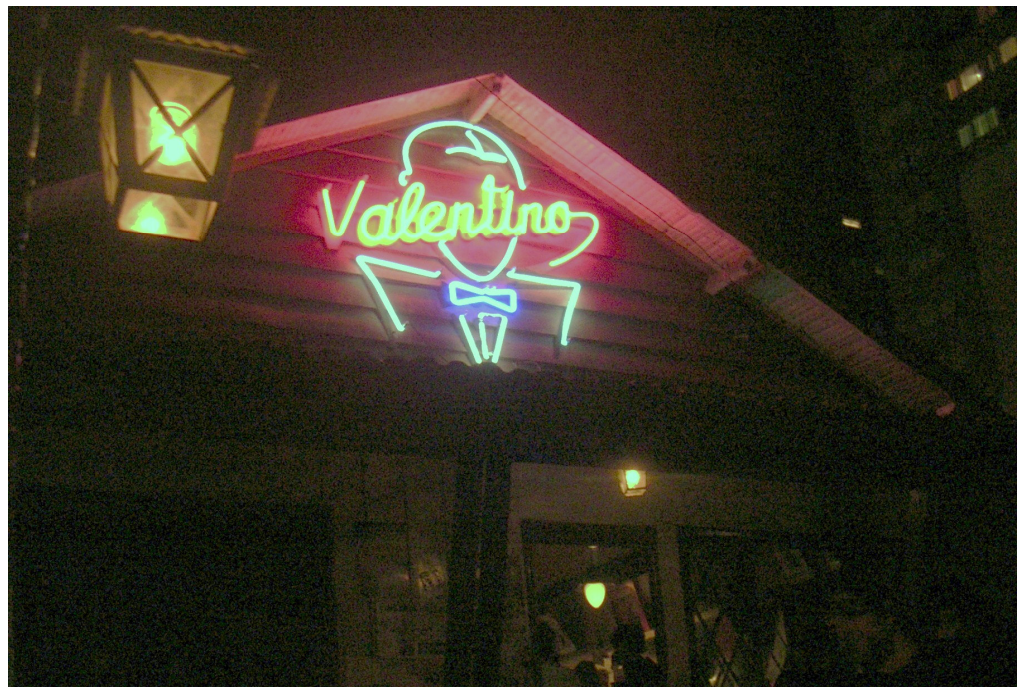

Foto 5. Letreiro do Bar Valentino (2005). Fonte: Acervo pessoal do autor. 
O espaço não cobrava entrada ou exigia consumação mínima de seus freqüentadores, exceto as quartas, quintas-feiras e aos domingos, quando eram realizados os eventos artísticos com a cobrança de um couvert que oscilava entre $2 \mathrm{R} \$ \mathrm{e}$ 5R\$. Eram mais comuns os shows de rock, blues e MPB, mas também havia lançamento de livros, peças de teatro, mostras de vídeo e, por vezes, alguns happenings - prática mais freqüente em anos anteriores. Ainda assim, nestas ocasiões a taxa era cobrada só até às $23 \mathrm{~h}$ e apenas para a permanência na casinha, permitindo que, no caso dos musicais, os freqüentadores os ouvissem da área externa sem que tivessem que desembolsar o dinheiro, algumas vezes contado. Quando o espaço recebia algum evento, uma das mesas da parte interna era posicionada na varanda, em frente à porta da casinha, onde alguém de confiança - algum amigo da banda ou do grupo de teatro, mas nunca um funcionário do bar - recolhia as entradas. Como no portão, nestas ocasiões algumas pessoas tentavam driblar a entrada no ambiente interno para acompanhar as apresentações artísticas sem pagar o couvert. A desculpa mais freqüente era o "banheiro". Sob a promessa de que não demorariam lá dentro e com a desculpa de que estavam "desesperadas e precisavam ir ao banheiro", os que entravam quase nunca voltavam.

Mesmo externamente, o ambiente era relativamente escuro e tudo ocorria à meia luz. A comunicação entre a área externa e a interna do bar era possibilitada por seis janelas que circundavam a casinha, além de uma porta bastante estreita se comparada à quantidade de frequientadores. Especialmente aos finais de semana, eram comuns algumas discussões rápidas e as trocas de olhares nada amistosos entre os que paravam na porta para paquerar ou conversar com algum conhecido e os que tentavam circular entre a área externa e a interna do bar. Uma das janelas se comunicava diretamente com o balcão na parte no interior da casinha permitindo que os freqüentadores fizessem seus pedidos mesmo quando localizados na área externa, enquanto as outras janelas permitiam uma rápida espiada nas apresentações artísticas aos que não se propunham a gastar com os ingressos.

Já no ambiente da casinha, o primeiro elemento a se destacar era o balcão ao estilo pub, com bancos altos, em madeira, por toda sua extensão. No interior do balcão havia um banner com a programação do mês; três frízeres onde eram geladas as cervejas; um móvel rústico, com alguns espelhos acoplados e garrafas de bebidas variadas; além de uma pia, onde eram lavados os copos e preparados os drinks. Dentre 
as pessoas, havia sempre um dos proprietários, responsável pelo caixa; dois ou três garçons, trajando boné e aventais vermelhos, com a logomarca do Bar Valentino estampada em branco; e, eventualmente, o DJ tocando discos de vinil ou CDs em frente ao som. Os bancos defrontes ao balcão, apesar de bastante concorridos, normalmente eram ocupados pelos freqüentadores mais antigos, os chamados "dinossauros" - que chegavam mais cedo ao bar, quando o movimento ainda não era tão intenso. Estes eram seus lugares preferidos, especialmente, pelo contato privilegiado proporcionado com os garçons e proprietários, já que, normalmente, os "dinossauros" não iam ao bar para "curtir o movimento", mas, sobretudo, para "pôr a conversa em dia" com alguns dos funcionários - muitos deles conhecidos de longa data. Já os demais usuários, quando conseguiam ocupar algum destes bancos geralmente sentavam-se de costas para o balcão, mais preocupados com o movimento no interior do bar do que com os funcionários.

Esta era uma das maneiras de se identificar algum freqüentador mais antigo ou aqueles que possuíam certo prestígio no espaço: se ele estivesse sentado em algum destes bancos altos, de frente para o balcão e conversando com algum dos funcionários, provavelmente, ele era um dos "dinossauros" do Bar Valentino; do contrário, possivelmente, ele seria algum freqüentador "comum". No trecho a seguir, retirado de uma entrevista realizada com João Durval - empresário, freqüentador do espaço desde 1991 e atualmente DJ residente do Bar Valentino aos sábados - percebe-se como, entre os freqüentadores mais antigos, a preferência pelo balcão está associada ao contato privilegiado com os proprietários e funcionários, além de como este era ocupado predominantemente por pessoas do meio artístico, classificando, de certa forma, os usuários mais tradicionais do bar:

T: E os freqüentadores? O quê mudou em relação aos freqüentadores daquela época [1991, 1992] pros últimos anos ali no centro?

J: Olha, daquela época de 1990 até o ano passado, 2006, que o Valentino ficou naquele mesmo endereço, eu acho que a essência se manteve. O pessoal ligado a todo esse lado GLS [Gays, Lésbicas e Simpatizantes], né? A veia cultural também. Eu gosto muito de usar essa expressão, me referindo ao Valentino como a veia cultural de Londrina. Na minha opinião, essa é uma definição que eu tenho do Bar Valentino. Ele é a veia cultural de Londrina. Podem ter outras, mas nenhuma é tão pulsante quanto o Valentino. Então, eu acredito que esse público, essencialmente... Porque eu sempre fui muito ali do balcão, né? Eu sempre gostei de tá ali no balcão, tomando minha 
cerveja no balcão e sempre procurando ter contato com os proprietários do bar, com o gerente, os garçons. Eu sempre tive um atendimento legal no balcão. Eu sempre gostei do balcão. Então, o público do balcão sempre foi esse. Meio que esse pessoal que eu falo que é da veia artística. Então, eu sempre gosto de conversar, de ficar no balcão. Aos poucos, por tá sempre ali no balcão, eu peguei amizade com o Chammé. Amizade da noite, né? Do balcão, de cliente de bar. Depois o Márcio e o Preá, que hoje também são proprietários, eu também já fui pegando amizade com eles também no balcão. Eu lembro que eu peguei mais contato o Márcio e com Preá quando eles passaram pra dentro do balcão. E eu sempre ali no balcão, do lado de fora e tal. E eu me lembro que às vezes eu chegava lá no Valentino por volta das quatro, cinco horas da manhã, e chegava um 'amigo' e falava: 'Ih, tá fechando a porta'. E eu falava: 'Ah, não. Pra mim não tem essa de que tá fechando não. Porque agora eu sou amigo dos caras aí e eles abrem pra mim'. Aí vinha o Chammé, quando via que era eu ele falava: 'Pode liberar, que o João pode entrar'. Depois isso aconteceu com o Márcio, com o Preá, e foi indo. Eu Virei cria da casa mesmo, né? (Trecho de entrevista, 11.10.2008).

Além da postura dos frequientadores que se sentavam nos bancos próximos ao balcão, mantendo-se de frente ou de costas para ele de acordo com sua intimidade com os proprietários e funcionários, este era um elemento que demarcava mais alguns símbolos que revelavam os freqüentadores mais antigos e assíduos, assim como os artistas que levavam maior público ao Bar Valentino. Havia quatro símbolos de status mais evidentes e demarcados a partir da relação de intimidade estabelecida no balcão: o próprio trânsito pelo seu interior, já que esta era uma área restrita aos proprietários e funcionários, e, portanto, às pessoas de grande confiança; o privilégio de "pendurar" a conta, que também denotava uma relação de confiança; usufruir de copos mais refinados e diferenciados dos demais freqüientadores ${ }^{27}$; e a oportunidade de interferir na seleção musical do bar. Por usufruir "temporariamente" destes quatro símbolos, os que atuavam como DJs nas noites temáticas, embora não fossem pessoas necessariamente próximas aos funcionários, possuíam muito prestígio no Bar Valentino, tornando-se, para muitos, o centro das atenções quando se apresentavam por ali ${ }^{28}$.

\footnotetext{
27 Certa vez, quando percebi que alguns freqüentadores recebiam copos diferenciados, um dos funcionários me afirmou que isso ocorria pelo fato de que tais copos não eram muito usados, e, portanto, eram mais limpos que os demais. Já em outro dia, quando flagrei uma dupla de amigos que recebera cada qual um copo diferente, o que havia recebido um dos copos diferenciados anunciou ao colega, em tom de piada: "No Valentino a condição social estabelece a diferença".

${ }^{28}$ Curiosamente, no dia em que entrevistei o atual proprietário do Bar Valentino eu pude usufruir temporariamente de alguns destes símbolos de status. Nesta ocasião, minha bebida ficou "por conta da casa", fui convidado a conhecer o acervo de discos no interior do balcão, além de ter recebido um dos copos diferenciados. Contudo, isto só me foi possível dada a minha condição explícita de pesquisador, na
} 
Uma outra forma de classificar os freqüentadores mais antigos e assíduos se dava pela relação ambiente externo/ambiente da casinha, como se observa em outro trecho da entrevista realizada com João Durval:

T: Alguns frequientadores dizem que mais ou menos no final da década de 90 o Bar Valentino foi apropriado também por um pessoal de perfil mais 'popular', digamos assim. Você concorda com isso?

J: Eu acredito que sim. Que teve essa mudança, essa questão popular. É uma coisa que pra mim é muito bem definida. Como eu coloquei aqui pra você, eu gosto muito do balcão. Então era difícil, muito difícil, eu chegar no Valentino e ficar na parte lá de fora. Era muito difícil. E eu conseguia perceber, no transitar da calçada até chegar no balcão, que o pessoal mais 'popular', como é colocado hoje, ficava lá fora. E o pessoal mais ligado ao Valentino, àquela questão cultural do bar, de ir assistir a banda que ia tocar naquela noite, pra assistir teatro, pagar o cachê, era aquele pessoal que ficava lá dentro. Que era restrito aquele espaço lá dentro pra 150, 200 pessoas. Então eu acho que isso ficava bastante claro, bem caracterizado. (Trecho de entrevista, 11.10.2008).

Paralelamente ao balcão, formava-se um corredor onde os freqüentadores circulavam para ir à parte externa, na frente, ou ao banheiro, aos fundos. Alguns ficavam ali apenas parados, conversando ou observando o movimento. Nos dias mais movimentados isso congestionava o bar, ocasionando muitas reclamações, principalmente, dos que pretendiam chegar aos banheiros. No meio deste corredor, próximo ao teto havia um espelho grande afixado no sentido horizontal, permitindo que, mesmo de costas para a porta, os freqüentadores avistassem quem entrasse ou saísse da casinha; pois, apesar de certa regularidade entre os que permaneciam na área externa e os que preferiam o ambiente externo, o fluxo era constante. Principalmente neste corredor e nas filas dos banheiros ocorriam as paqueras e a inevitável "esfregação". Em meio ao constante movimento do corredor, os pisões, esbarrões e a "esfregação" nem sempre eram involuntários, já que o relativo anonimato em meio ao fluxo de pessoas permitia que os mais atirados sempre tirassem uma "lasquinha" dos que passavam por ali.

qual fui considerado como alguém "importante" no Bar Valentino. Em outras ocasiões, quando estive ali como freqüentador, inúmeras vezes meus pedidos para fotografar o bar do interior do balcão foram negados pelos funcionários. Afinal, nestas ocasiões eu já não era o "importante" pesquisador, mas apenas mais um dos freqüentadores "comuns". 
A maior concentração das mesas no ambiente interno se dava em uma área cercada pelo palco, não muito maior que uma sarjeta, e o corredor descrito acima. Nas noites em que eram realizados os eventos artísticos estas eram as mesas preferidas pelo público, que nas apresentações mais concorridas procurava chegar mais cedo para garantir um bom lugar. Do contrário, nas noites em que não havia apresentações, o palco era preenchido com duas mesas, que por sua elevação davam uma visão privilegiada do interior do bar para os que se sentavam ali. Já nas noites temáticas, as mesas eram retiradas e quase todo o espaço, inclusive o palco, era transformado em pista de dança. Nestas noites o ambiente também ganhava uma iluminação especial com alguns canhões de luz meio improvisados e não muito sofisticados.

Afora os banheiros e a cozinha, a única divisão no interior da casinha - dentre as visíveis para os usuários - era feita por uma parede entre o espaço em frente ao palco, onde se concentrava a maioria das mesas no ambiente interno, e um outro corredor, paralelo à parede lateral inclinada, onde havia cerca de cinco ou seis mesas mais reservadas. Estas mesas eram mais procuradas por casais, tanto heterossexuais como homossexuais. Nesta parede, uma grande vitrine chamava a atenção por expor alguns quadros, esculturas ou fotografias de artistas locais, ou ainda alguns objetos nonsense, além do figurino utilizado em alguma das peças apresentadas no bar. Nos banheiros e neste corredor mais reservado, por vezes, também era possível flagrar rápidas negociações de drogas, principalmente, envolvendo maconha e cocaína. Os banheiros masculino e feminino, localizados ao final deste corredor, raramente estavam limpos e eram minúsculos se comparados à densidade do público. Sempre com filas, seus arredores eram locais potenciais para os flertes e "cantadas". Enquanto nas filas as paqueras eram entre homens e mulheres, que lado a lado aguardam sua vez, não era muito rara a notícia de que havia duas pessoas do mesmo sexo se "amassando" ou "passando dos limites" no interior dos banheiros, principalmente no feminino.

Logo em frente aos banheiros havia um pequeno mural onde eram estrategicamente afixados os cartazes com os próximos eventos do bar. Ao lado, havia ainda mais um pequeno balcão, com alguns bancos altos em frente a outro espelho posicionado na horizontal. Embora o público não tivesse acesso, nos fundos estava localizado o depósito de bebidas, a área de serviço, o vestiário dos funcionários, além da cozinha, onde era preparado o tradicional "macarrão da madrugada" e os sanduíches 
que homenageavam os grandes nomes do cinema, como o Josephine Baker, com pão de centeio, molho tártaro, presunto, queijo, pêssego e ameixas.

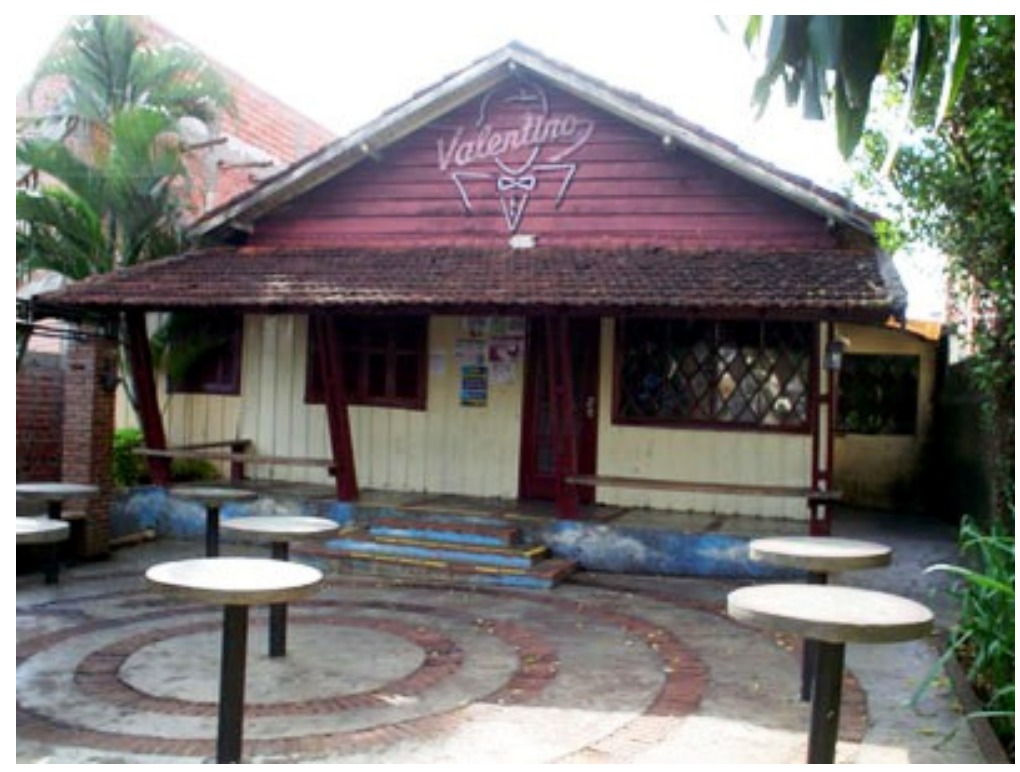

Foto 6. Área externa do Bar Valentino à luz do dia. Fonte: Acervo pessoal do autor (2005).

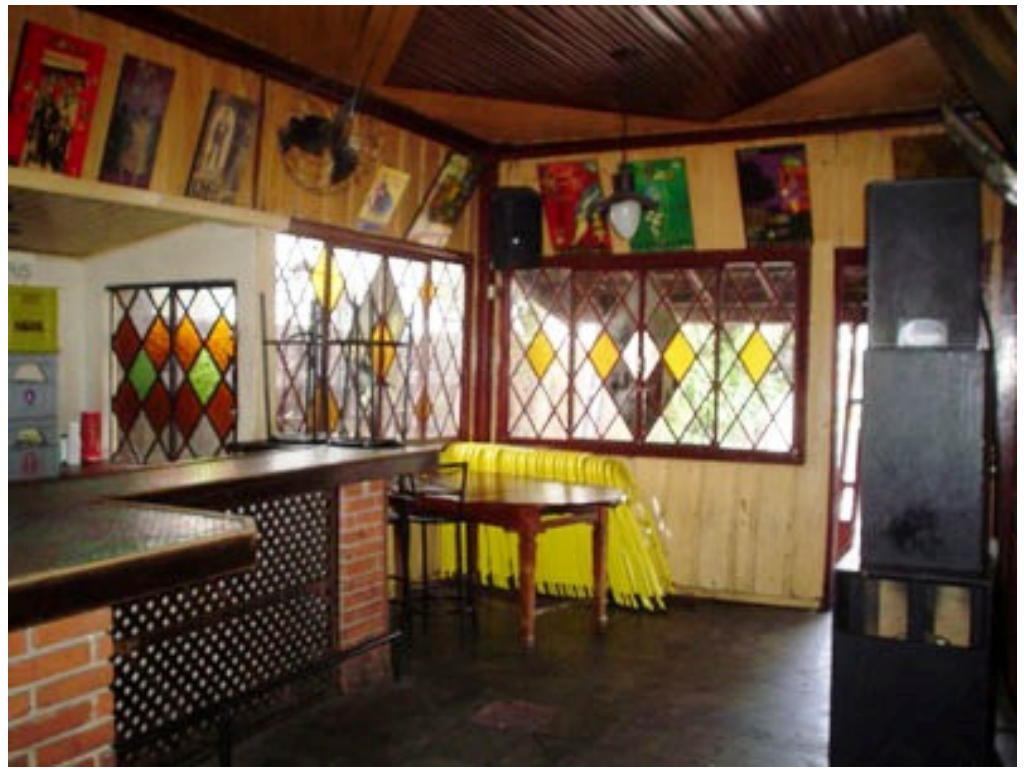

Foto 7. Área interna do Bar Valentino à luz do dia. Fonte: Acervo pessoal do autor. 
Quase todas as paredes do Bar Valentino eram repletas de quadros que relembravam os melhores eventos realizados ali. Se o artista se destacasse e o cartaz do evento agradasse, ele teria boas chances de ser "eternizado" na forma de quadro, transformando-se em parte da decoração do bar. Por isso, os artistas que possuíam alguns dos seus cartazes dispostos como quadros gozavam de grande prestígio no espaço, pois todos sabiam que algum dia eles haviam realizado uma apresentação "inesquecível" ali. Estes quadros misturavam-se a outros, que estampavam obras de Tolouse-Lautrec, ícones pop ou grandes nomes do rock, como Janis Joplin, Pink Floyd e Frank Zappa. Afora as noites temáticas, com seus DJs específicos, o ambiente era quase sempre embalado ao som do jazz, do blues, do rock das décadas de 1970 e 1980, além da música alternativa da década de 1990. Em seus últimos anos na região central, a música eletrônica também passou a ser trilha sonora do bar.

Boa parte da decoração dos primeiros anos do Bar Valentino resistiu às reformas e à sucessão de proprietários, e as referências artísticas estavam em toda parte: nas paredes, no cardápio - que estampava o slogan do bar, "para quem está in, out, up and down -, na vitrine que expunha obras de arte, e, principalmente, nos freqüentadores. Não era difícil encontrar alguém declamando um poema em uma roda de amigos ou ao ouvido de alguma garota, ou, em algum canto, um dos freqüentadores esboçando versos e rabiscos em meio à atmosfera "inspiradora" do bar. Em vários blogs na internet, por exemplo, é possível encontrar memórias do Bar Valentino escritas em tom poético, como se destaca a seguir:

Terça-feira fui ao Valentino e tinha uma festa à fantasia. Quem pode ter tempo para se fantasiar em plena terça-feira simplesmente para ir ao Valentino? Somente estes seres-barata da noite que freqüentam o Valentino. Como me sinto às vezes. Porque todo dia é provisório e somente a noite parece ser real, essas noites da Londrina que parece estar dormindo límpida e branca, cônjuge do absurdo da vida cotidiana. E estavam terça-feira vestidos de Mortícias, mexicanos de sombreiros, mascarados. Mas na verdade se fantasiam todas as noites que vão ao Valentino - e são todas. Vestem-se de diferentes personagens e habitam o imaginário daqueles que vão ao Valentino de relance e não voltam nunca mais, porque se sentem ultrajados por esses 'tipos'. Admito que até eu às vezes tenho medo do Valentino. Mas tomar um conhaque lá é sempre uma opção interessante.

Nas sombras daquela memória nós dormimos. Vimos nos bancos frios e mortos uma multidão intacta de bêbados felizes. Vimos as janelas 
velhas se abrirem para todos as 'tribos' de uma cidade que ensaia em ser metrópole. Ah! Essa casa velha, de esquina, cujas madeiras escondem um universo à meia-luz. Um universo de pessoas diferentes num convívio que a sociedade cega chama de orgia; uma orgia em nome da liberdade e da cultura múltipla vive soberana naquelas mentes que compõem o 'Vale'. Um bar feito de mentes, muitas delas, diferentes e soltas. Um terreno de história e tempo, onde mais de uma geração se sobrepõe diante do retrato de Gilda e da pergunta: 'perfidamente teu, quer dizer o que necessariamente?'. E mais, o querem dizer aquelas informações todas que gritam daquele balcão em mosaico? Ouviram-se nomes de garçons por toda a história desse monumento pulsante à diversidade. Ouviram-se risadas, gritos de brigas, zunidos de balas e até gemidos nos escuros. Ainda se ouve naqueles lustres, que mirando nas testas dos distraídos, extraem mais um motivo de riso. Lá a vida não passa, ela simplesmente deixa de ser. Hoje deixa de ser ontem e amanhã provavelmente deixará de ser hoje. Mas ninguém pára e pensa a respeito. Porque o Valetino é assim, uma porta. Se é de saída ou de entrada, quem decide é a história de cada um, que no final forma a história do Valentino como o mosaico do balcão.

Ainda que em seus últimos anos no centro o Bar Valentino já não possuísse mais o mesmo "improviso" dos primeiros tempos, a espontaneidade ainda eram uma das características marcantes do espaço. Embora a programação fosse fechada com aproximadamente um mês de antecedência, nunca se sabia quando o bar receberia uma decoração especial ou quando ocorreria algum "evento surpresa", por assim dizer. Como já ocorreu, por exemplo, se aparecesse um grupo de drag-queens para desfilar o figurino no bar ou se no auge da bebedeira alguém mais exaltado tirasse parte da roupa, isso não causava muito espanto. Pelo contrário, quando o público não respondia com indiferença - que caracterizava uma das máximas dos usuários do Bar Valentino, o "cada um na sua" -, estas atitudes inusitadas animavam a noite ou, em situações mais extremas, até mesmo eram saudadas com aplausos pelos demais freqüientadores.

Pela relativa espontaneidade característica ao espaço, durante as entrevistas realizadas com seus freqüentadores eram comuns as afirmações que atribuíam ao local um clima "mágico", "exótico" ou "místico", como: "Quem é mais antigo curte essa magia que o Valentino tem"; "Acho o máximo tanta gente diferente junta, cada um na sua. O lugar é exótico, romântico, meio louco"; ou então, "Quando você vai num bar claro, você não se acostuma que nem aqui. Essa penumbra, essa coisa meio mística". Em uma entrevista concedida em 2005 - quando o espaço ainda estava localizado na região central da cidade -, uma de suas freqüentadoras relembra algumas situações 
classificadas em seu depoimento como "inusitadas" e "imprevisíveis" que exemplificam bem a espontaneidade característica ao Bar Valentino:

Bom, além da clássica história dos tiros [quando houve um homicídio no Bar Valentino em 1998], que eu tava lá, já vi coisas bem diferentes. Já vi cinco menininhas de uns 15 anos 'revezando' o mesmo cara. Já vi homem batendo em mulher e mulher batendo em homem. Já ganhei uma garrafa de vinho 'na faixa' daquele velhinho com a cara de Papai Noel e depois ele saiu do bar com uma travesti. Eu lembro também de um cara falando que tomou chá de cactus e que começou a recitar uma poesia 'muito louca' pra mim e pras minhas amigas. E outro dia dois ex-presidiários 'deram em cima' de suas lésbicas e levaram 'porrada'. Elas empurraram eles pra fora do bar na 'porrada'. (Trecho de entrevista, 12.05.2005).

Em outra entrevista, concedida por Waldomiro e Rosângela Chammé para uma matéria especial sobre os 21 anos do Bar Valentino, veiculada na edição de 28 de outubro de 2000 do Jornal de Londrina, os atuais proprietários do espaço também destacam algumas situações curiosos presenciadas no bar, como:

[...] no dia em que a Orquestra da Colômbia fazia uma intervenção teatral e um cliente que tinha bebido demais começou a invocar com a atriz que falava o texto em espanhol porque achou que ela discutia com ele. [ou quando] [...] era noite de show com o Marquinhos Diet, quando uma mulher entra no bar com um aparelho de telefone fixo, tipo convencional da Ericson, no ouvido, falando alto. Ela dizia: 'mamãe, eu não posso falar agora, estou no Valentino, mamãe'. Virava para alguém da platéia e dizia 'é minha mãe, você quer falar com ela?'. E o curioso é que, mesmo sem entender nada, as pessoas entravam na história. Até o músico abaixou o volume. A mulher saiu sem dar explicação. (MENDONÇA, 2000).

Especialmente pela relativa monotonia característica às madrugadas de uma “cidade média” o Bar Valentino também atraía muitos freqüentadores por permear seus imaginários com a idéia de que ali era um "lugar diferente" e propício ao acontecimento de episódios imprevisíveis a cada noite. Tendo em mente a história do espaço, a idéia que se criou de um "lugar diferente", que muitas vezes era percebido como "mágico", "exótico" ou "místico" por seus freqüentadores, na realidade pode ser explicada pela "vocação artística" que lhe foi atribuída já em seus primeiros anos, que tornou valores como o "improviso" e a "espontaneidade" altamente valorizados e favorecidos - apesar 
de cerceados por algumas restrições impostas em tempos mais recentes. Afinal, como propõe Magnani, os espaços e equipamentos urbanos devem ser entendidos como "cenários", ou seja, enquanto "[...] produto de práticas sociais anteriores e em constante diálogo com as atuais - favorecendo-as, dificultando-as e sendo continuamente transformado por elas" (2000: 37). Neste sentido, as referências simbólicas que inicialmente dotaram o Bar Valentino de uma apropriação mais exclusiva, ao longo do tempo tornaram-se um dos fatores atrativos para que grupos diversos e heterogêneos passassem a procurar o espaço a fim de compartilhá-las.

\subsubsection{Os Trajetos e os Circuitos no Centro}

Além da realização de eventos bastante diversificados e das referências historicamente atribuídas ao Bar Valentino, existem outros fatores relevantes - como, por exemplo, seu horário de funcionamento - que fizeram deste espaço um aglutinador de grupos sociais heterogêneos. Enquanto esteve localizado na região central de Londrina, por funcionar quase todos os dias da semana - de terça-feira a domingo -, das 21 h até a saída do último cliente, conforme os demais equipamentos de lazer noturno fechavam suas portas, o Bar Valentino permanecia aberto e ganhava cada vez mais público. Nos dias de semana era muito comum que o bar ficasse relativamente vazio durante boa parte da noite e passasse a receber muitos freqüentadores por volta das duas, três, horas da manhã, quando inclusive funcionários e proprietários de outros espaços encerravam o expediente por lá.

Outro fator que contribuiu para que o Bar Valentino passasse a aglutinar um público bastante diverso era a sua localização central. Este espaço ocupava uma posição na malha urbana considerada "privilegiada" por seus frequientadores, não apenas pela grande oferta de linhas de ônibus que atendiam a sua região e pela quantidade de "repúblicas" estudantis em sua proximidade - já que em seus últimos anos na região central a maioria de seu público era composta por estudantes universitários -, como também por encontrar-se "no meio do caminho" de todos os outros bares mais centrais. Dentre estes bares, alguns estavam localizados bem próximos ao Bar Valentino, 
caracterizando sua região como uma mancha - no caso, uma mancha de lazer. Ou seja, enquanto:

[...] uma área contígua do espaço urbano, dotada de equipamentos que marcam seus limites e viabilizam, cada qual à sua especificidade, competindo ou complementando, uma atividade prática dominante [no caso da região do Bar Valentino, o 'lazer']. As atividades que oferecem e as práticas que propiciam são resultadas de uma multiplicidade de relações entre seus equipamentos, edificações e vias de acesso, garantindo uma continuidade e transformando-a em ponto de referência, físico, visível e público para um número amplo de usuários. (MAGNANI, 1982: 96).

Além do Bar Valentino, entre 2004 e 2005, esta mancha de lazer era composta por mais quatro bares ("Bar do Jota", "Sem Censura", "Mangá" e "Artimanha”); três lanchonetes ("Lanchebom", “Arnaldo Lanches" e "Rangus”); uma pizzaria ("Ravenna"); um ginásio de esportes ("Moringão"), onde ocasionalmente eram realizados jogos de basquete e handball, eventos solenes e alguns shows de grande porte; um parque ("Zerão"), com um anfiteatro onde também ocorriam alguns shows organizados pela prefeitura municipal, geralmente aos domingos; e uma feira noturna ("Feira da Lua"), realizada às quartas-feiras no estacionamento deste parque. O Bar Valentino constituía-se como o equipamento urbano mais atrativo desta mancha de lazer, estabelecendo uma relação de complementaridade com todos os outros espaços citados; alguns com os quais tinha maior afinidade, como o "Bar do Jota", e outros com os quais tinha um pouco menos, como a pizzaria "Ravenna". Dada a relação de contigüidade espacial entre estes equipamentos urbanos, especialmente aos finais de semana, ocorria um fluxo considerável de deslocamentos, principalmente, entre os bares e lanchonetes que compunham esta mancha de lazer.

Como observa Magnani (2000), os deslocamentos no interior das manchas urbanas ocorrem por meio de trajetos que não se realizam de forma aleatória, mas de maneira lógica, fundamentada em escolhas e sistemas de compatibilidades. Assim, dentre as inúmeras combinações possíveis em meio ao fluxo ocorrido nesta mancha de lazer, era possível abstrair algumas regularidades nestes deslocamentos. Aos sábados, por exemplo, quando havia apresentações musicais no "Artimanha", mas não no Bar Valentino, um dos trajetos possíveis se dava pelo deslocamento "Bar do Jota $\rightarrow$ Artimanha $\rightarrow$ Bar Valentino $\rightarrow$ Lanchebom”, quando muitos usuários desta mancha: 
(01) Bebiam algumas cervejas ou jogavam partidas de bilhar no primeiro estabelecimento, que abria por volta das $18 \mathrm{~h}$, possuía preços mais acessíveis e não cobrava qualquer tipo de taxa; (02) Posteriormente, acompanhavam o musical no segundo; (03) Passavam pelo terceiro, que mantinha público até mais tarde; e, (04) encerravam a noite comendo um lanche no quarto, que estrategicamente funcionava quase até o amanhecer aguardando os que saíam do Bar Valentino.

Outros trajetos se caracterizavam por sua curta extensão, envolvendo apenas dois equipamentos desta mancha, mas nem por isso deixavam de ser significativos em sua regularidade. Às quartas-feiras quando eram realizadas apresentações artísticas no Bar Valentino, muitos de seus freqüentadores passavam pela "Feira da Lua" e comiam um aperitivo antes de adentrarem aos eventos, enquanto que aos finais de semana o deslocamento "Bar Valentino $\rightarrow$ Anfiteatro do Zerão $\rightarrow$ Bar Valentino" era constante entre aqueles que saíam do bar para fumar um "baseado", algumas vezes em mais de uma ocasião por noite.
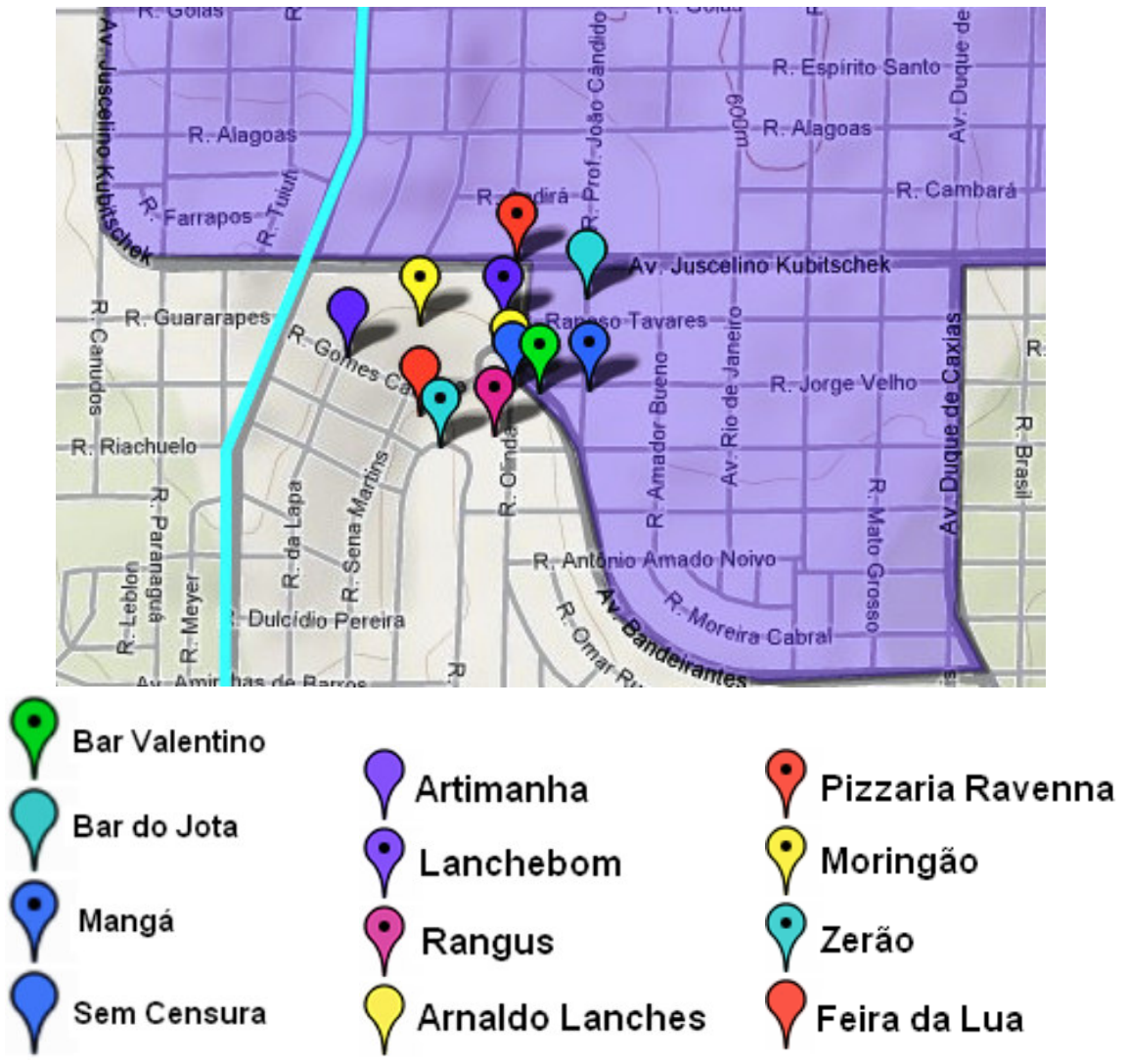

Mapa 8. "Mancha" de lazer na região central de Londrina (2004 - 2005) Fonte: www.google.maps; editado pelo autor. 
Mas certamente, no período em questão, o trajeto que mais se consolidou no interior desta mancha de lazer era marcado pelo deslocamento "Bar do Jota $\rightarrow$ Mangá (ou o inverso) $\rightarrow$ Bar Valentino". O fato de este trajeto figurar entre o mais citado durante as entrevistas está associado não apenas ao envolvimento de dois dos equipamentos de lazer noturno mais antigos desta mancha - o Bar Valentino, de 1979, e o "Bar do Jota", inaugurado em 1980 -, mas também por incorporar espaços que possuíam formas de apropriação bastante nítidas. Afinal, aos três bares era atribuída uma referência GLBTT, reconhecida tanto por seus usuários assim como por aqueles que normalmente não os freqüentavam.

Visto que apesar desta referência comum, o "Bar do Jota" comportava um público de perfil mais universitário, ligado em artes e admirador de MPB, enquanto que o "Mangá" era mais procurado por "moderninhos", adeptos do rock e de música eletrônica, o trânsito entre estes espaços era intenso, sobretudo no começo da madrugada. Pois, mediante este fluxo, portadores da mesma preferência sexual poderiam ter contatos e experiências - não apenas sexuais - com pessoas consideradas "interessantes" exatamente por freqüentarem espaços diferentes. Contudo, considerados por seus freqüentadores como locais "muito claros" e "expostos", devido à comunicação direta com a rua, a lógica deste trajeto era fechada no Bar Valentino, onde os contatos mais íntimos realmente aconteciam. Este fato pode ser observado no trecho a seguir, extraído de uma entrevista com uma das freqüentadoras destes espaços - estudante universitária, que se considera "homossexual":

T: Na sua opinião, o 'Jota' e o 'Mangá' são 'bares gays'?

L: Ah, aqueles bares ali ['Bar do Jota', 'Mangá', 'Sem Censura' e 'Bar Valentino'] são pontos de referência pro pessoal GLS. Assim, não que eles sejam só aquilo, tipo 'bar gay', por exemplo. O 'Jota' mesmo é mais 'L' [Lésbicas] do que 'G' [Gays]. Mas com certeza o pessoal GLS acaba marcando em alguns desses lugares.

T: E qual a diferença deles pro Valentino?

L: Ah, eles são mais sossegados. Você vai mais pra beber, pra conversar com seus amigos. No Valentino também, mas eles são mais sossegados. Você vai neles e depois vai pro Valentino.

T: E por que isso?

L: Ah, porque ali ninguém fica, ninguém beija. Porque os donos tratam a gente bem, o Joaquim do 'Jota' principalmente, mas tem um fator muito importante: você tá na rua. Ali as pessoas passam de ônibus, passam de carro e elas tão te vendo. Então ali as pessoas se 
controlam ao máximo, ninguém faz nada, entendeu? Não acontece da homossexualidade 'vista', como no Valentino. As pessoas sabem quem é, mas não fazem nada ali. Então começa nesses bares, com as olhadas e tal e termina no Valentino. (Trecho de entrevista, 12.05.2005).

No entanto, pela reunião dos quatro fatores citados até aqui - a realização de apresentações artísticas variadas; as referências adquiridas ao longo do tempo; seu horário de funcionamento; e sua localização central -, enquanto permaneceu no centro de Londrina, o Bar Valentino não apenas possuía uma relação de complementaridade com os demais equipamentos localizados em sua mancha de lazer, como também atraía o público de equipamentos de lazer noturno um pouco mais distantes. Neste caso, o bar constituía-se enquanto um elemento recorrente entre diversos trajetos de mais longa extensão, aglutinando freqüentadores de equipamentos complementares entre si, mas que não eram ligados por uma relação de contigüidade espacial. Neste caso - conforme a definição proposta por Magnani, na qual o circuito “[...] une estabelecimentos, espaços e equipamentos caracterizados pelo exercício de determinada prática ou oferta de determinado serviço, porém não contíguos na paisagem urbana” (2000: 45) -, tornase possível falar em um circuito de lazer noturno no qual o Bar Valentino surgia enquanto um de seus principais elementos.

Da mesma forma que o Bar Valentino era o maior atrativo da mancha de lazer na qual estava localizado, este espaço também era uma das referências do circuito de lazer noturno em Londrina, ao lado de equipamentos como os bares "Vilão", "Casa da Cachaça", "Bar Brasil" e "Pau-Brasil", as boates "Acústico", "Fashion", "Empório Guimarães", “Todas as Tribos" e "F.R.I.E.N.D.S.”, e a conveniência "Pátio San Miguel" - que figuram entre os mais citados durante as entrevistas. No entanto, se no caso de sua mancha o Bar Valentino era, em algum grau, complementar a todos os outros equipamentos, em meio ao circuito de lazer noturno ele se conectava diretamente a alguns espaços - como o "Vilão", o "Bar Brasil" e a "F.R.I.E.N.D.S." - mas era oposto a outros - como o "Acústico" e o "Empório Guimarães". Em alguns casos, a afinidade se dava de maneira intermediária, já que o Bar Valentino era incluído em certos trajetos apenas de maneira ocasional, que não dependiam necessariamente dele para terem suas lógicas fechadas - como as relações estabelecidas, por exemplo, entre o bar e a boate "Todas as Tribos". 

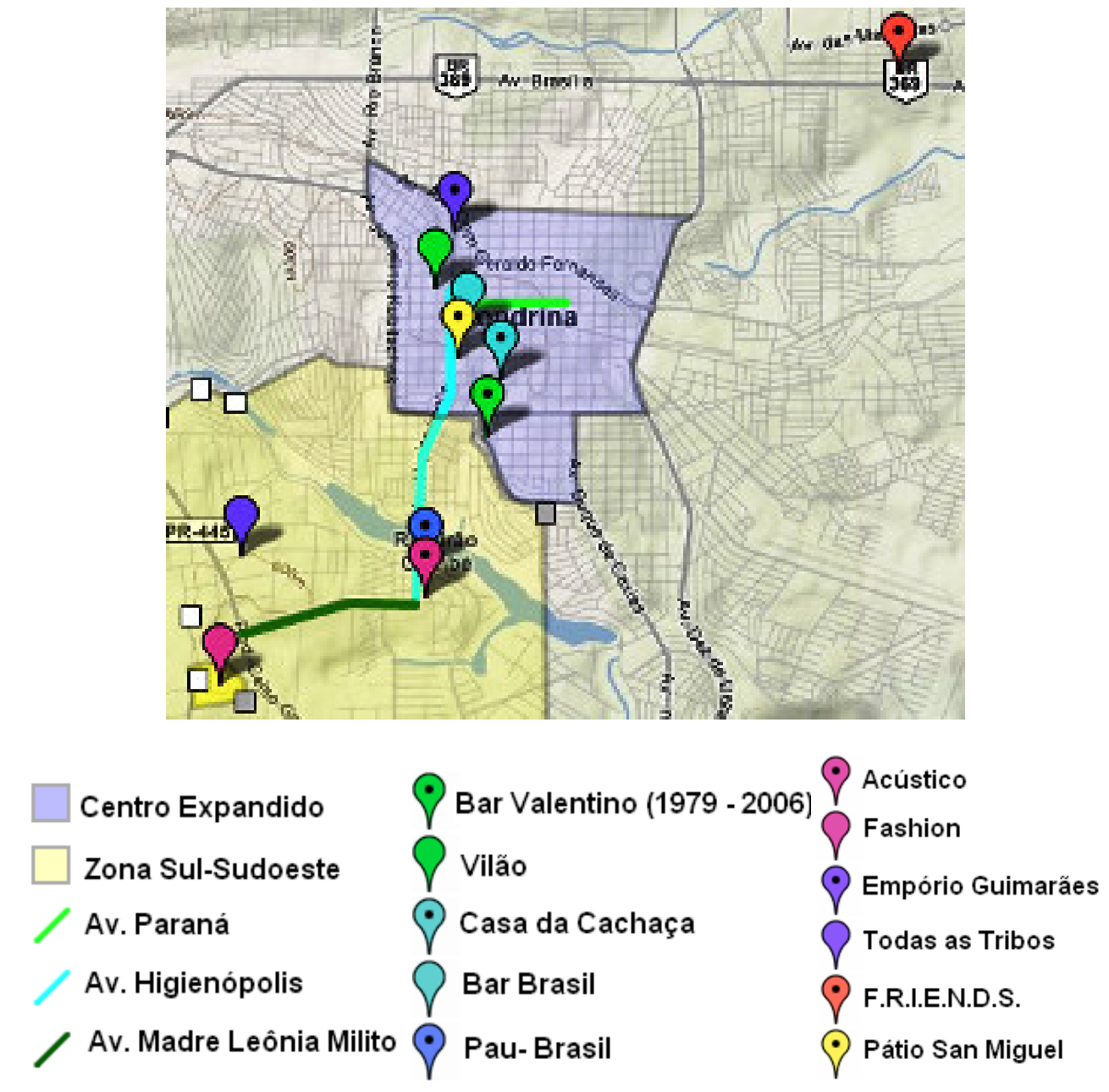

Mapa 9. Principais referências do circuito de lazer noturno em Londrina (2004 - 2005). Fonte: www.google.maps; editado pelo autor.

Tomando o Bar Valentino como referência, dada à diversidade e à heterogeneidade de seu público, a partir dos trajetos estabelecidos por seus freqüentadores em seu trânsito mais amplo pela cidade, constata-se a existência de alguns circuitos derivados em meio ao circuito de lazer noturno em Londrina - como, por exemplo, o "circuito GLBTT", o "circuito universitário de MPB", o "circuito dos "manos", o "circuito de artes", "o circuito do rock" e o "circuito das "patricinhas' e playboys"”, entre outros. Afinal, “[...] é possível distinguir circuitos em múltiplos planos: desde um mais abrangente, que reúne as mesmas modalidades de uma mesma prática - é o circuito principal - até segmentos mais particularizados, congregando setores específicos [...] são os circuitos derivados". (MAGNANI, 1999: 68. Grifos do autor). 
Dentre os diversos circuitos derivados nos quais o Bar Valentino era tido como referência, alguns deles se destacavam mais do que outros por dependerem deste espaço para que a lógica de seus trajetos fosse concluída. Este é o caso, por exemplo, do "circuito GLBTT", que em seu trajeto característico possuía a mesma coerência apresentada pelo deslocamento dos grupos GLBTT no interior da mancha de lazer do Bar Valentino, embora incorporasse outros equipamentos um pouco mais distantes, como o bar "Varanda" e a boate "F.R.I.E.N.D.S.". Enquanto o "Varanda" era caracterizado pela intensa movimentação durante o "happy hour" ${ }^{29}$, sendo procurado pelos adeptos do "circuito GLBTT" antes da realização do deslocamento típico em meio à mancha citada, em algumas ocasiões a boate "F.R.I.E.N.D.S." era incorporada ao final do trajeto. Assim, quando considerada a escala do circuito, o deslocamento "Bar do Jota $\rightarrow$ Mangá (ou o inverso) $\rightarrow$ Bar Valentino", poderia expandir-se para "Varanda $\rightarrow$ Bar do Jota $\rightarrow$ Mangá (ou o inverso) $\rightarrow$ Bar Valentino $\rightarrow$ F.R.I.E.N.D.S.”, mediante a seguinte lógica:

\begin{tabular}{|c|c|c|c|c|}
\hline Varanda & Bar doJota & Mangá & Bar Valentino & F.R.I.E.N.D.S. \\
\hline$\rightarrow$ & $\rightarrow$ & $\rightarrow$ & $(\rightarrow)$ & \\
\hline $\begin{array}{l}\text { "Happy } \\
\text { Hour". }\end{array}$ & Flerte/Paquera. & Flerte/Paquera. & $\begin{array}{l}\text { Contato } \\
\text { Íntimo. }\end{array}$ & $\begin{array}{c}\text { Contato } \\
\text { Íntimo. }\end{array}$ \\
\hline
\end{tabular}

- $(\rightarrow)$ : Deslocamento Ocasional.

- $\rightarrow$ : Deslocamento Regular.

Tabela 2. Trajeto característico ao “circuito GLBTT” em Londrina (2004 - 2005).

Já no caso do que se poderia chamar de "circuito universitário de MPB", tomando o Bar Valentino como referência, constata-se certa regularidade nos trajetos

\footnotetext{
${ }^{29}$ A expressão, que do inglês pode ser literalmente traduzida como "hora feliz", refere-se ao período de tempo após o trabalho onde as pessoas se reúnem, por exemplo, em cinemas, bares e restaurantes para realizar o que Toledo (2002) designa como "higiene mental". Para o autor, especialmente no "happy hour", os usuários destes espaços encontram-se num interstício social entre as esferas do trabalho e do não-trabalho. Pois, se nestas ocasiões não se observa o "repouso" sob a ótica do capital, como um fator determinante para a reprodução da força de trabalho, tão pouco se totaliza a idealização da experiência do tempo livre, essencialmente desvinculado do ritmo da cotidianidade.
} 
realizados por aquela parcela de estudantes que dava maior preferência aos bares com música ao vivo do que, por exemplo, às boates. Sob este recorte mais específico, é possível observar deslocamentos tidos como típicos neste circuito, compostos pelas possibilidades de trajetos entre "Universidades $\rightarrow$ Bar Brasil $\rightarrow$ Artimanha ou Casa da Cachaça ou MPB Bar / Clube da Esquina ou Bar do Jota $\rightarrow$ Bar Valentino”, e que em algumas ocasiões poderia incluir ainda espaços como o bar "Papo-Cabeça" e a boate "Todas as Tribos".

No que se refere especificamente aos estudantes da Universidade Estadual de Londrina, a lógica intrínseca às diversas possibilidades de trajetos que caracterizavam um "circuito universitário de MPB" se dava: (01) Pela realização ocasional de apresentações de MPB após as aulas do período noturno em espaços próximos à universidade ("Papo-Cabeça”, “Todas as Tribos”); (02) Pelo horário de funcionamento do "Bar Brasil" - até às $2 \mathrm{~h}$ - considerado um espaço de passagem, onde se "inicia a noite"; (03) Pelos eventos regulares de MPB em alguns espaços (“Artimanha”, "Casa da Cachaça" ou "MPB Bar") ou pela reunião de apreciadores deste ritmo e instrumentistas em outros equipamentos ("Bar do Jota”, "Clube da Esquina”); e, finalmente, (04) Pelo horário de funcionamento mais avançado e pela proximidade que o Bar Valentino possuía com muitas das "repúblicas" estudantis, que facilitava o retorno para casa ao final da noite. Como se observa no exemplo a seguir:

\begin{tabular}{|c|c|c|c|}
\hline $\begin{array}{c}\text { Papo- } \\
\text { Cabeça }\end{array}$ & Bar Brasil & $\begin{array}{c}\text { Casa da } \\
\text { Cachaça ou Bar } \\
\text { do Jota }\end{array}$ & Bar Valentino \\
\hline$(\rightarrow)$ & $\rightarrow$ & $\rightarrow$ & \\
\hline $\begin{array}{c}\text { Próximo } \\
\text { à UEL; } \\
\text { Shows } \\
\text { de MPB. }\end{array}$ & $\begin{array}{c}\text { Local de } \\
\text { Horário de }\end{array}$ & $\begin{array}{c}\text { Shows de MPB } \\
\text { ou Reunião de } \\
\text { Instrumentistas. }\end{array}$ & $\begin{array}{c}\text { Horancionamento de } \\
\text { Localização. }\end{array}$ \\
\hline
\end{tabular}

- $(\rightarrow)$ : Deslocamento Ocasional.

- $\rightarrow$ : Deslocamento Regular.

Tabela 3. Exemplo de trajeto característico ao "circuito universitário de MPB" em Londrina (2004-2005). 
Outro circuito derivado que, especialmente nos últimos anos, passou a ser apreensível mediante a referência do Bar Valentino, é aquele que seus freqüentadores denominavam pejorativamente de "circuito dos "manos" - ou, conforme os termos nativos, "bares dos "manos"'. Este circuito era composto pelos deslocamentos exercidos por grupos provenientes de bairros distantes e periféricos, que, sobretudo aos finais de semana, deixavam suas "quebradas" 30 para curtir a balada no centro da cidade. Além do Bar Valentino, o trajeto típico deste "circuito dos "manos" no centro de Londrina era composto por mais três equipamentos bastante próximos entre si e que compartilhavam de algumas características em comum: os bares "Kotovelo’s" e "Pé na Cova" e o posto de combustível "Ecos" 31 - que não exigiam qualquer tipo de taxa aos seus freqüentadores, possuíam preços bastante acessíveis, além de concentrarem a maior parte de seu público na rua, em frente aos estabelecimentos, normalmente ao redor de seus carros e motos.

Em alguns domingos, este trajeto era incrementado pelo bar "Vila Café" ou pelo anfiteatro do "Zerão". Nestes casos, o atrativo eram as apresentações musicais sem a cobrança de ingresso; mas, enquanto no primeiro predominavam os grupos de samba ou pagode, no segundo, apresentavam-se artistas diversos em shows promovidos pela prefeitura municipal. No entanto, quando se considera o trajeto "Kotovelo's $\rightarrow$ Posto Ecos $\rightarrow$ Pé na Cova", esse circuito diferia do "circuito GLBTT" ou do "circuito universitário de MPB" pelo fato de que, enquanto alguns dos espaços que compunham estes dois últimos muitas vezes eram partilhados por diversos grupos ("Bar do Jota", "Bar Brasil"), no caso do "circuito dos "manos"”, os equipamentos escolhidos eram marcados por uma apropriação mais exclusiva. Sem dúvida, a região na qual estavam localizados os espaços que compunham este circuito se configurava enquanto um pedaço no centro da cidade, onde eram exercitados códigos, condutas e lealdades

\footnotetext{
${ }^{30}$ Como observa Pereira (2005) em sua etnografia sobre os pichadores na cidade de São Paulo, o termo "quebrada" em seu uso nativo alude tanto a uma forma de pertencimento aos moradores das periferias paulistanas como também traz uma conotação de perigo, associada à periferia, principalmente, para aqueles que não as habitam ou que se aventuram em "quebradas" que não as suas.

${ }^{31} \mathrm{Na}$ etnografia realizada por Clara Azevedo e Ana Luíza Borges sobre a "mancha de lazer" na Vila Olímpia, bairro de classe média na cidade de São Paulo, também é citado um posto de combustível como um espaço integrante dos trajetos característicos a esta região. Como afirma Magnani (2005) “[...] diferentemente do que se esperaria desse tipo de estabelecimento - local de passagem para abastecimento ou rápida parada para compra de algum item na loja de conveniência - ele se transformou em local de encontro e até de lazer. Para muitos, a balada na Vila Olímpia começa e termina no próprio posto" (MAGNANI, 2005: 187). O posto "Ecos" cumpre uma função semelhante em meio ao "circuito dos "manos"” na região central de Londrina.
} 
comuns à população dos diversos bairros periféricos de Londrina. Ou seja, esta era uma região onde:

[...] os freqüentadores não necessariamente se conhecem - ao menos não por intermédio de vínculos construídos no dia-a-dia do bairro -, mas sim se reconhecem como portadores dos mesmos símbolos que remetem a gostos, orientações, valores, hábitos de consumo, modos de vida semelhantes. Está-se entre iguais nestes lugares: o território é claramente delimitado por marcas exclusivas. O componente espacial do pedaço, ainda que inserido num equipamento ou lugar de amplo acesso, não comporta ambigüidades porque está impregnado pelo aspecto simbólico que lhe empresta a forma de apropriação característica. (MAGNANI, 2000: 39 - 40. Grifo do autor).

Ao contrário da mancha, onde o componente espacial predomina sobre o simbólico, tornando-a acessível a pessoas de várias procedências, o pedaço, menos dependente da variável territorial, pode ser deslocado pela malha urbana: muda-se de ponto e levam-se junto os códigos e condutas de seus usuários habituais. Neste sentido, no decorrer da noite, muitos dos freqüentadores daqueles equipamentos que compunham parte do "circuito dos "manos", dirigiam-se ao Bar Valentino levando consigo alguns aspectos de seu pedaço - como a música que lhes era característica irradiando de seus automóveis e a preferência pela sociabilidade nas ruas e calçadas em frente ao bar.

A escolha pelo Bar Valentino, que à primeira vista poderia parecer oposto aos equipamentos que compunham este circuito, provavelmente advinha pelo compartilhamento de algumas características comuns entre este espaço e aqueles freqüentados pelos "manos" no centro da cidade: ou seja, a gratuidade e a fácil comunicação com a rua. Assim, como faziam em seu pedaço, os chamados "manos" poderiam observar da rua - com seus carros estacionados, ouvindo rap - o intenso movimento nos arredores do bar. Pelo horário de funcionamento do Bar Valentino, aos que não possuíam condução, dali ainda era possível aguardar o primeiro ônibus rumo a sua "quebrada" sob a proteção e a lealdade estabelecida nas calçadas ali mais próximas. Afinal, nessa época, pelo menos do portão do Bar Valentino para fora, aqueles arredores se aproximavam muito mais de um pedaço dos "manos" do que, por exemplo, dos 
"GLBTT" ou dos "apreciadores de MPB" ${ }^{32}$. O quadro a seguir exemplifica o trajeto característico ao "circuito dos "manos"” na região central da cidade:

\begin{tabular}{|c|c|c|}
\hline $\begin{array}{c}\text { Kotovelo's ou Pé na } \\
\text { Cova ou Posto Ecos }\end{array}$ & $\begin{array}{c}\text { Vila Café ou Anfiteatro } \\
\text { do Zerão }\end{array}$ & Bar Valentino \\
\hline$\rightarrow$ & $(\rightarrow)$ & Gratuidade; \\
Gomunicação Com a & $\begin{array}{c}\text { Shows Ocasionais; } \\
\text { Gratuidade; } \\
\text { Rua. }\end{array}$ & $\begin{array}{c}\text { Comunicação Com a } \\
\text { Rua. }\end{array}$ \\
\hline
\end{tabular}

- $\quad(\rightarrow)$ : Deslocamento Ocasional.

- $\rightarrow$ : Deslocamento Regular.

Tabela 4. Trajeto característico ao "circuito dos 'manos"' na região central de Londrina. (2004 - 2005).

No caso do "circuito de artes" em Londrina, a referência do Bar Valentino evidenciava trajetos que tipicamente constituíam uma rede um pouco mais ampla que os circuitos derivados expostos até aqui. Pois, neste caso, no que se refere aos deslocamentos estabelecidos a partir do bar, os entrevistados não se limitavam a aludir predominantemente os equipamentos de lazer noturno, mas também cinemas, exposições, teatros e escolas de teatro, lojas de discos, sebos, a Secretária Municipal de Cultura, a Casa de Cultura da UEL, a Concha Acústica e as escadarias do Edifício Centro Comercial ${ }^{33}$. Desta forma, eram inúmeras as possibilidades de trajetos observadas ou citadas durante as entrevistas, que, de alguma forma, conectam o Bar Valentino aos demais espaços que compõem o "circuito de artes" em Londrina. No entanto, ainda assim, é possível abstrair alguma lógica intrínseca a estes deslocamentos.

\footnotetext{
${ }^{32}$ Como será analisado no próximo item deste capítulo, intitulado “2.3. Os Últimos Anos no Centro".

${ }^{33}$ Evidentemente, isso não significa que os demais "circuitos" tivessem seus trajetos limitados apenas à conexão entre equipamentos de lazer noturno. No caso do "circuito GLBTT", por exemplo, havia trajetos que conectavam os bares citados a espaços como lojas de roupas ("Fashion Mix") e salões de cabeleireiros ("Sete Copas“, "La Peluqueria”.) Já no que se refere ao "circuito universitário de MPB”, os bares escolhidos por seus adeptos também se conectavam a certas lojas de discos e instrumentos musicais, além das próprias universidades. Já no caso do "circuito dos "manos"”, existiam conexões entre seu "pedaço" no centro da cidade e espaços como o Terminal Central de Ônibus Urbanos e o Shopping Royal Plaza.
} 
Uma das possibilidades seria o trajeto "Secretaria Municipal de Cultura ou Casa de Cultura da UEL $\rightarrow$ Concha Acústica ou escadarias do Edifício Centro Comercial $\rightarrow$ Drinks Bar ou Bar do Jaime $\rightarrow$ Bar do Jota ou Bar Vilão $\rightarrow$ Bar Valentino”. Neste caso, a lógica do trajeto dar-se-ia: (01) Pela visita a alguma exposição artística ou pela necessidade de tomar providências quanto à organização de algum evento ("Secretaria Municipal de Cultura" ou "Casa de Cultura da UEL"); (02) Pela passagem por algum espaço público onde se reunia o pessoal ligado em artes para se informar sobre eventos e exposições ("Concha Acústica" ou "escadarias do Edifício Centro Comercial”); (03) Pela prática do happy hour ("Drinks Bar" ou "Bar do Jaime”); (04) Pelo início da noite no "Bar do Jota" ou no "Vilão"; e, (05) Pela realização de algum evento no Bar Valentino.

Este trajeto ainda poderia ser incrementado caso fosse realizado por alunos ou professores de alguma escola de teatro, se o adepto do circuito aproveitasse o deslocamento pelo centro da cidade para passar na loja de discos "Jardim Elétrico" ou pelos inúmeros sebos localizados na região, ou, ainda, se houvesse peças e exposições em cartaz, que provavelmente substituiriam o início de noite no "Bar do Jota" ou no "Vilão". Contudo, quaisquer que fossem as opções e combinações entre estes diversos equipamentos, certamente, o trajeto teria sua lógica concluída no Bar Valentino. Pois era neste espaço que se concretizavam muitos dos planos idealizados nas escadarias, praças e botecos das imediações da Secretaria Municipal de Cultura, ou, do contrário, era para lá que todos se dirigiam para celebrar os eventos ocorridos em outros espaços. A “Tabela 5" apresentada na página seguinte exemplifica a lógica intrínseca ao trajeto característico ao "circuito de artes" em Londrina.

Os circuitos derivados expostos até aqui se constituíam como os mais evidentes estabelecidos a partir do Bar Valentino porque dependiam deste espaço para que a lógica de seus trajetos fosse concluída. Como foi exposto, isso ocorria pela possibilidade dos adeptos do "circuito GLBTT" estabelecerem ali um contato mais íntimo entre si; pela localização do bar, próximo às "repúblicas", facilitando a volta para a casa daqueles que vivenciavam o "circuito universitário de MPB"; pela proteção proporcionada aos "manos", que dali aguardavam o primeiro ônibus da manhã rumo a sua "quebrada" de origem; ou, pela concretização e celebração dos eventos planejados pelo pessoal do "circuito de artes". Desta forma, poderia se falar, por exemplo, em um "circuito do rock" na cidade de Londrina. No entanto, embora o Bar Valentino figurasse 
ocasionalmente neste circuito, este espaço não era fundamental para a conclusão de seus trajetos. Neste caso, normalmente esta função era exercida pelo bar "Potiguá" - também localizado na região central, com seu horário de funcionamento estendido até o amanhecer. Ao final dos trajetos, era neste equipamento que os adeptos do "circuito do rock" ouviam suas músicas características, se informavam sobre o lançamento de novos álbuns ou discutiam os shows daquela noite, realizados em espaços como o "Music Hall" e os bares "Armazén" e "Boca Quente". Este circuito era fechado no Bar Valentino apenas de maneira esporádica, quando ali eram realizadas as apresentações de algumas bandas que aglutinavam grande parte dos "rockeiros" da cidade ou quando ocorria a noite temática “Terça Tilt", realizada apenas quinzenalmente.

\begin{tabular}{|c|c|c|c|c|}
\hline $\begin{array}{c}\text { Secretaria } \\
\text { Municipal de } \\
\text { Cultura }\end{array}$ & $\begin{array}{c}\text { Concha } \\
\text { Acústica }\end{array}$ & Drinks Bar & Vilão & $\begin{array}{c}\text { Bar } \\
\text { Valentino }\end{array}$ \\
\hline$\rightarrow$ & $\rightarrow$ & $\rightarrow$ & $(\rightarrow)$ & $\rightarrow$ \\
\hline $\begin{array}{l}\text { Exposições; } \\
\text { Organização } \\
\text { de Eventos. }\end{array}$ & $\begin{array}{c}\text { Encontro no } \\
\text { Eúblico; } \\
\text { Informação. }\end{array}$ & Happy Hour. & $\begin{array}{c}\text { Início de } \\
\text { Noite. }\end{array}$ & $\begin{array}{c}\text { Evento; } \\
\text { Celebração. }\end{array}$ \\
\hline
\end{tabular}

- $\quad(\rightarrow)$ : Deslocamento Ocasional.

- $\quad \rightarrow$ : Deslocamento Regular.

Tabela 5. Exemplo de trajeto característico ao "circuito de artes" em Londrina (2004 - 2005).

Assim, da mesma forma que o "circuito do rock" não dependia necessariamente do Bar Valentino, estabelecendo com ele uma afinidade apenas ocasional, outros circuitos, como o das "patricinhas e playboys", ainda podem ser abstraídos por sua oposição ao bar. O contraponto entre este espaço e os equipamentos que compunham este circuito ocorria, sobretudo, em relação aos hábitos de consumo (gratuidade de entrada e cerveja, considerada como uma bebida "barata" vs. opção por espaços e bebidas consideradas "caras", como uísque, tequila, vodka), à seleção musical (jazz, blues, MPB, rock vs. música sertaneja, pop, dance music) e às formas de apropriação do espaço público nos arredores (footing vs. "footing motorizado"). Neste sentido, os 
equipamentos e os trajetos que compunham o "circuito das "patricinhas e "playboys"" notadamente não eram mencionados pelos freqüentadores do Bar Valentino por meio de afinidade, mas sim pela negação, como: "nunca fui no 'Acústico', não faço isso", "a 'Fashion' não faz parte da minha realidade", ou, quando muito, “já fui, mas não gostei”. Este fato pode ser observado no trecho a seguir, extraído de uma entrevista realizada com um dos freqüentadores do Bar Valentino - estudante de Artes Cênicas, que normalmente transitava entre alguns espaços do "circuito GLBTT" e do "circuito de artes":

T: Em quais outros lugares [além do Bar Valentino] você vai?

S: Valentino, 'Jota' e às vezes na 'F.R.I.E.N.D.S.' .

T: E você não tem conhecidos em outros lugares?

S: Tenho, mas eu não gosto. Não tenho amigos em outros lugares, tenho colegas e conhecidos.

T: E porque você acha que só tem amigos no Valentino?

S: Acho que porque o pensamento é o mesmo, o gosto é o mesmo. Porque no Valentino não são as mesmas pessoas que saem por aí pra ir no 'Acústico'. Eu nunca fui no 'Acústico', não faço isso. No Valentino é música boa, todo mundo gente boa, com o mesmo pensamento. Por exemplo, uma vez eu fui na 'Fashion' e eu não gostei não. Porque ali aconteceu umas palhaçadas tão grandes que eu fiquei 'de cara'. Um fotógrafo tava fotografando um casal e tinha uma menina, assim, meio 'modelinho' bem do lado. Aí o cara foi cutucar ela, pra ela dar licença, e ela achou que o cara ia fotografar ela. Aí ela começou a fazer pose, colocou a mão na cintura. Assim, ridículo. O povo entra nessa 'nóia', 'eu tenho dinheiro, então eu posso'. Esse não é meu pensamento. Isso não faz parte da minha realidade. (Trecho de entrevista, 08.03.2005).

Dadas as oposições entre o Bar Valentino e alguns espaços, normalmente associados às camadas mais privilegiadas da população da cidade e considerados por muitos de seus freqüentadores como "fúteis" e "elitizados", é possível traçar, de forma aproximada, algumas possibilidades de trajetos típicos ao "circuito das 'patricinhas' e "playboys"”. Uma das probabilidades seria o deslocamento "lojas de conveniência ou Bar Brasil $\rightarrow$ Pau-Brasil / Fashion ou Empório Guimarães ou Acústico $\rightarrow$ Pátio San Miguel", no qual a lógica do trajeto provavelmente dar-se-ia: (01) Pela reunião em locais que não exigiam nenhuma espécie de taxa (conveniências ou "Bar Brasil"); (02) Pela entrada em algum bar ou boate ("Pau-Brasil" ou "Fashion”, "Empório Guimarães", 
“Acústico"); e, (03) Pelo encerramento da noite na conveniência 24h "Pátio San Miguel" - considerado bastante "cara" pelos freqüentadores do Bar Valentino -, onde as chamadas "patricinhas" e "playboys" procuravam uma última possibilidade de paquera, comiam algum doce ou salgado, ou bebiam a "saideira" antes do retorno para casa.

Assim sendo, conforme as escolhas e preferências dos freqüentadores do Bar Valentino em seus deslocamentos pela malha urbana, constata-se que, por fatores diversos, este espaço constituía-se em um "ponto de confluência" entre alguns circuitos derivados que notadamente dependiam dele para que a lógica de seus trajetos fosse concluída - como o "circuito GLBTT", o "circuito universitário de MPB”, o "circuito dos "manos" e o "circuito de artes". Mediante o mapeamento destas preferências, ainda vêm à tona o "circuito do rock", fundamentado em uma afinidade regular com o Bar Valentino, ou, conforme os termos nativos o "circuito das "patricinhas' e "playboys", que pode ser apreendido de maneira aproximada pela própria contraposição ao espaço. Mas, sobretudo, no que diz respeito aos circuitos derivados que invariavelmente confluíam no Bar Valentino, constata-se ainda uma regularidade comum a todos eles.

Como é possível visualizar no "Mapa 10” exposto a seguir, quando excluídos os equipamentos que proporcionavam deslocamentos considerados como "ocasionais" como a boate "F.R.I.E.N.D.S." no "circuito GLBTT", o bar "Papo-Cabeça" e a boate "Todas as Tribos" no "circuito universitário de MPB", além de algumas salas de cinema no caso do "circuito de artes" -, estes circuitos derivados que invariavelmente confluíam no Bar Valentino, se realizavam no chamado "centro expandido da cidade" ou em áreas próximas a ele. Partindo do pressuposto de que a paisagem urbana não é um cenário inerte, estático, mas um processo que determina certo repertório de possibilidades (MAGNANI, 2007), constata-se, então, que no período em questão os circuitos estabelecidos sob a referência do Bar Valentino se concretizavam sob as probabilidades e os obstáculos impostos por uma "cidade média", fundada em um centro único - onde as áreas mais distantes a esta região não são muito atrativas pela relativa ausência de equipamentos urbanos voltados ao lazer, ao comércio ou aos serviços, que se encontram predominantemente localizados no próprio núcleo central.

Assim, observa-se que pelas próprias possibilidades de uma "cidade média" os trajetos mais significativos constituídos a partir do Bar Valentino possuíam um padrão 
“centralizado", muitas vezes realizado na escala da "caminhada" ${ }^{34}$ e com a lógica de seus deslocamentos concluída em uma só noite. Certamente, é por este fato que alguns equipamentos, notadamente os mais longínquos do núcleo central, surgiam como "ocasionais" para os adeptos destes circuitos derivados em meio ao circuito de lazer noturno em Londrina.

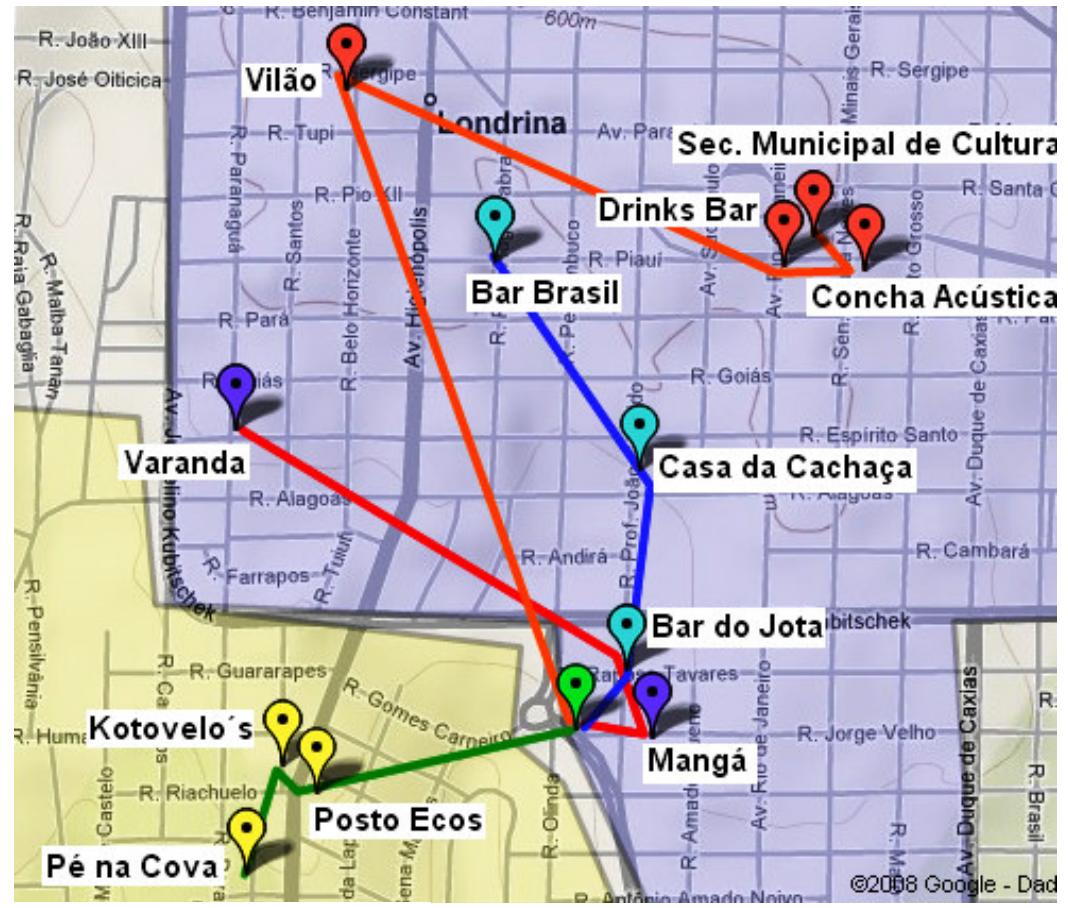

\section{Centro Expandido}

\section{Zona Sul-Sudoeste}

$\supsetneq$ Bar Valentino (1979 - 2006)

"Trajeto" típico ao "circuito GLBTT"

"Trajeto" típico ao "circuito universitário de MPB"

\section{"Trajeto" típico ao "circuito dos 'manos'" no centro de Londrina "Trajeto" típico ao "circuito de artes"}

Mapa 10. Sobreposição de trajetos característicos a alguns circuitos de lazer noturno em Londrina (2004 -2005).

Fonte: www.google.maps; editado pelo autor.

\footnotetext{
${ }^{34}$ Fato que pode ser confirmado pelo depoimento concedido por Waldomiro Chammé, atual proprietário do espaço, para uma edição do Jornal de Londrina de dezembro de 2004, quando, ao comentar sobre a possibilidade de transferência do Bar Valentino para uma área mais longínqua da cidade, estimou que "[...] cerca de 70\% dos freqüentadores vêm [iam] [para lá] a pé”. (NAVARRO, 2004: 14).
} 


\subsection{Os Últimos Anos no Centro: Dos Cadernos de Cultura às Páginas Policiais}

Embora os circuitos derivados formados sob a referência do Bar Valentino evidenciassem padrões de interações sociais típicos de uma "cidade média", nos últimos anos em que o espaço esteve localizado na região central de Londrina, as relações sociais estabelecidas entre alguns de seus freqüentadores já se mostravam como reveladoras de certos aspectos capazes de exprimir a atual fase de crescimento e expansão do município. Nos anos que sucederam a transferência do bar, constata-se, por exemplo, o sensível aumento da criminalidade e de práticas ilícitas em seus arredores; fato que muito provavelmente está associado à tendência de descentralização da malha urbana, e, consequientemente, dos investimentos públicos e privados em infra-estrutura, saúde, educação e, sobretudo, em segurança pública realizados na cidade.

Como observa Caldeira (2000) em sua análise etnográfica sobre o crime e a segregação na cidade de São Paulo, desde meados da década de 1980, em uma época coincidente com a transição para o regime dito "democrático", houve um aumento considerável dos crimes violentos em todo o país. Para a autora, isto se deve a um "ciclo da violência", resultante tanto de variáveis sócio-econômicas - decorrentes da passagem da década de 1970, marcada por um intenso crescimento econômico, para a chamada “década perdida", em 1980, quando o salário mínimo foi substancialmente reduzido e a inflação registrou índices altíssimos, implicando no acirramento das disparidades

sociais - quanto de uma combinação de fatores sócio-culturais - como o padrão violento de ação da polícia, a descrença no sistema judiciário como mediador público e legítimo de conflitos, além da resistência à democratização, que implicaram na privatização dos processos de justiça e vingança que, realizados de maneira extralegal, combatiam a violência com medidas igualmente violentas.

Para autoras como Zequim (2004) e Carvalho (2008), esta tendência no aumento de crimes violentos foi singularizada em Londrina, sobretudo, a partir de 2001, quando dentre o número de mortes ocasionadas por fatores externos, os homicídios ultrapassaram aquelas causadas por acidentes de trânsito. Conforme estas análises, isto se deve à recente inserção da cidade em uma rede ilícita bastante ampla, que ultrapassa os próprios limites do município. A consolidação desta rede é atribuída pelas autoras a fatores como o aumento de habitações em áreas de caráter irregular; a transformação de 
Londrina de "ponto de passagem" para "local de processamento de drogas", especialmente a cocaína, com a conseqüente inclusão de jovens moradores destas áreas no mercado do tráfico; e à legitimação, por parte do poder público, do contrabando e da venda ilegal de mercadorias com a criação do "camelódromo", assim como de diversas "galerias populares" no centro da cidade.

Apesar das autoras constatarem que recentemente as mortes violentas em Londrina mostram-se tendencialmente concentradas em áreas periféricas, geralmente de ocupação irregular, e embora não existam pesquisas sobre a criminalidade no centro da cidade, a própria experiência cotidiana e os artigos que diariamente ocupam as páginas dos jornais locais evidenciam o aumento dos crimes e a sensação de insegurança na região ${ }^{35}$. Este fato também é sintomático quando são consideradas algumas medidas tomadas recentemente por parte do poder público na tentativa de combater a violência nesta área, como, por exemplo, a implantação de "módulos móveis" da polícia militar (Jornal de Londrina, 21.10.2007), o deslocamento de duplas de policiais para várias das esquinas do centro (FRAZÃO, 2008), além da instalação de câmeras de vigilância, em caráter experimental, nos pontos mais críticos (GALEMBECK, 2007). Neste sentido, acredito que as relações sociais estabelecidas entre alguns freqüientadores do Bar Valentino, nos anos que precederam sua mudança de endereço, são particularmente esclarecedoras quanto ao aumento da criminalidade no centro de Londrina.

Retomando brevemente a história do Bar Valentino, observa-se que a partir de meados da década de 1980, quando houve a "profissionalização" dos eventos e a significativa ampliação de seu público, ocorreu também um aumento sensível no uso e na circulação de drogas ilícitas no espaço. Como já foi observado, isso implicou na adoção de algumas medidas por parte de Marcos Marangoni, proprietário do bar na época - como o fechamento aos sábados e a presença de policiais à paisana -, a fim de conter esta situação. Conforme o depoimento concedido pelo ex-proprietário, exposto na página 53, tais medidas não estiveram associadas, por exemplo, à contenção de furtos e assaltos, mas sim diretamente ligadas à restrição da circulação das drogas, já que “[...] em seis, cincos anos lá [ele] nunca [teve] problema com ladrão”. Contudo, estes

\footnotetext{
35 Para citar apenas alguns exemplos, "Polícia Alerta Para Estupros no Zerão". (NAVAROO, 2005); "Polícia Militar Instala Primeira Câmera na Próxima Semana". (GALEMBECK, 2007); "24 Horas no Terminal Urbano: à noite o tempo não passa - solidão e medo tomam conta”. (GOUVEIA, 2007); e "Crianças São Suspeitas por Disparos em Lan House". (ARAÚJO, 2007); "PM Instala 'Módulo Móvel' no Terminal" (Jornal de Londrina, 21.10.2007); e, "Duplas de Policiais Desaparecem e População Volta a Ter Medo" (FRAZÃO, 2008).
} 
procedimentos não parecem ter sido suficientes, uma vez que o uso de drogas no espaço e em seus arredores intensificou-se em anos posteriores, quando, conforme os termos de um antigo freqüentador, "começou a ficar preta a coisa".

Como se observa no trecho a seguir, a circulação de drogas no Bar Valentino é prática comum pelo menos desde o início da década de 1980. No entanto, conforme o freqüentador entrevistado, se nesta época isso de dava de forma "inofensiva" e "recreativa", em tempos mais recentes houve uma "bad trip" ${ }^{36}$, quando o uso das substâncias ilícitas no espaço desencadeou práticas violentas como roubos e homicídios:

M: Quando eu conheci o Valentino, em 82, 83, nem cocaína eu não cheirava. Fumava maconha só, e olhe lá. Mas eu gostava de tá ali. Mas o 'foda' lá é que a cerveja era cara pra 'caralho'. Então eu não ia tomar cerveja lá. Eu bebia em outro boteco e ia pra lá. Já chegava bêbado. O pessoal comprava as 'paradas' em outro lugar, cheirava e ia pra lá. O Valentino era bom pra cheirar no banheiro, mas tinha que pegar fila. Mas era um tempo que todo mundo se conhecia. As pessoas chegavam com a sua 'balinha' no bolso, iam no banheiro, davam um 'tirinho', sentava, achava que era Deus e falava a noite toda. Mas o que aconteceu já no começo de 2000, final da década de 90 , que o crack começou a tomar conta da cena, começou a ficar uma coisa pesada.

T: Como assim, pesada?

M: Violenta. Foi o mesmo que aconteceu em São Francisco com o final do movimento hippie. Que começou a bad trip. Droga pesada, morte, assassinato, Hell Angel, Charles Manson. Foi a mesma bad trip que começou a acontecer ali no Valentino. Roubo, aí um cara leva um tiro lá dentro. Ficou 'preta' a coisa. (Trecho de entrevista, 13.03.2007).

Se no período em que o Bar Valentino permaneceu nas mãos de Marcos Marangoni, entre 1986 e 1991, o ex-proprietário afirma que, apesar do aumento de incidências de drogas, nunca houve problemas relacionados à violência, no depoimento acima se percebe que no final da década de 1990 houve uma intensificação de práticas criminosas e de atos violentos nos arredores do bar - como furtos, assaltos, brigas, arrombamentos de carros, e até mesmo a ocorrência de estupros e dois homicídios. Com a ocorrência do primeiro homicídio em 1998, quando um homem foi morto a tiros na varanda do bar em decorrência de um acerto de contas envolvendo drogas, novas

\footnotetext{
${ }^{36}$ A expressão, que traduzida do inglês significa literalmente "viagem ruim", é uma gíria comum entre usuários de drogas para designar os efeitos indesejáveis causados pelo uso de determinadas substâncias.
} 
medidas foram tomadas, agora pelos atuais proprietários, visando coibir estas ações, além de proporcionar maior sensação de segurança aos freqüentadores. Algumas destas medidas podem ser observadas no trecho a seguir, extraído da entrevista realizada com Waldomiro Chammé em 2004, onde o proprietário também destaca certa limitação na espontaneidade que sempre foi característica ao espaço e pontua algumas ações criminosas que passaram a ser freqüentes. Quando questionado sobre as mudanças realizadas na estrutura física do Bar Valentino entre a época em que este fora vendido pela última vez, em 1991, e o momento da realização da entrevista, o proprietário respondeu:

V: O que eu acho sobre isso é que ele [o bar] foi perdendo a espontaneidade que ele tinha, né? Porque sempre foi um bar de entrar a hora que quiser, muita liberdade e tal. E as coisas que aconteciam... Acontecia, assim, uma briguinha de namorado que encontrou a namorada com outro cara, ou bêbado que invocou com alguém, dá uma 'porrada' e todo mundo já aparta, sabe? E hoje tem que ter uma estrutura de proteção mesmo, sabe? Por exemplo, as grades que têm no bar, tem uma hora da madrugada que já não entra mais ninguém, têm seguranças todas as noites. Então a gente foi criando regras pra tentar conter, assim, a violência, né? Perigo de assalto e tal. Porque o bar já foi assaltado. Porque hoje em dia você já distingue quem é da periferia, quem é dos 'Cinco Conjuntos'. Pelo jeito que o cara se comporta, pelo jeito que o cara se veste. E já começa a existir, assim... Antes mesmo das pessoas conviverem elas já falam: 'eu vou me cuidar, porque quem é que sabe se vai acontecer algum problema'. Então você vai se protegendo de outras pessoas. E isso é um retrocesso, porque começa dividir em camadas sociais, né?

T: Então aqui no bar você percebe isso?

V: Percebo. Apesar que aqui eu acho que é um lugar que comparativamente todo mundo se encontra. $\mathrm{O}$ que acontece hoje em dia é que as pessoas ficam meio com medo, assim, de uns 'mano', quando chega com aqueles bermudão, aqueles negocinho e tal. Mas isso também é uma oportunidade meio que única. Assim, porque aqui é assim mesmo, um espaço que é de todo mundo, das 'tribos' todas se encontrarem, da noite acontecer normalmente, né? Mas eu acho que hoje em dia existe um cuidado. Um cuidado pra ir no carro, porque vira e mexe um carro é arrombado aqui. Mas é como em qualquer lugar da cidade, né? Então eu acho que isso aí é uma pena, sabe 'cara'? Porque restringe pra 'caramba'. É complicado isso aí. E ao mesmo tempo eu não vou ser leviano de ignorar que tem perigo. Deixar tudo aberto. Entrar e sair a hora que quiser, né?

T: E teve uma época que o pessoal estava proibindo a entrada com bonés e toucas. Por que isso?

V: Bom, na verdade foi o seguinte. Assim, a gente percebeu que o pessoal que não quer ser identificado dentro do bar usa muito boné, porque é uma maneira de ele se disfarçar, colocando o boné até perto 
do nariz e tal. E a gente faz reunião toda semana pra conversar sobre os problemas e tal. A gente tem estratégias de trabalho aqui. Então uma estratégia nossa foi de evitar... Primeiro de tudo, impedir menor de idade de entrar. Mas existe uma questão. Primeiro, que é o tráfico. Tá sendo muito usado crianças pra traficar. Crianças que eu falo são menores de 18, porque eles são inimputáveis e tal. Então o traficante fica fora daqui, longe daqui, e manda o menor de idade trazer droga pro bar. Pra vender droga dentro do bar. Então a gente optou por não deixar mais menor entrar. Então tem que fazer todo um trabalho ali na entrada. Com isso a gente decidiu também pedir pro pessoal não entrar de boné. Mas que era pra guardar na bolsa, entendeu? E as pessoas meio que estranharam. E foi muito curioso pra nós, porque alguém que não tava interessado em mostrar a cara, ou ele não entrava ou ele virava as costas e falava: 'se não pode entrar de boné, eu não entro'. E ia embora. Que era o que a gente queria. Que as pessoas não entrassem aqui. Ou se ela entrava, ela ficava 'na boa'. Tipo, como se de uma certa forma ele tivesse medo de tá sendo identificado. Porque aqui, com uma certa freqüência some bolsa, some celular. E as pessoas são displicentes. A 'mulherada' chega e pendura a bolsa, esquece, vai no banheiro, vai não sei aonde. Porque quem rouba, às vezes é quem quer comprar droga. Enfim, né? Então a gente sentiu que depois que a gente tomou essa medida, praticamente não teve nenhum furto de bolsa, nem de celular, nem de nada. Ficou uns três meses vigorando, só que o público nosso do dia a dia foi tão resistente a isso, ficou tão 'puto da vida', deu tanto rolo, que a gente optou em parar. Porque apesar de ser uma medida eficiente, nosso público entendeu como uma tentativa de coibir comportamento. (Trecho de entrevista, 26.10.2004).

No depoimento de Waldomiro Chammé percebem-se tanto algumas transformações na estrutura física do bar - presença de grades, muros mais altos, seguranças no portão - quanto na conduta dos freqüentadores, que passaram a ter um cuidado maior para irem aos carros e adquiriram certa desconfiança em relação ao "outro" - no caso citado, os "manos". Especialmente no que se refere a este último fator, constata-se a incorporação de certos hábitos e costumes que, de certa forma, exprimem alguns aspectos do crescimento da cidade. Pois, ao contrário de outros tempos, onde "todos se conheciam", mais recentemente os usuários do espaço passaram a compartilhá-lo sob as ressalvas decorrentes dos "perigos da cidade grande".

Situação similar é observada por Almeida \& Adum (2007) em sua pesquisa sobre o Bosque Municipal Mal. Cândido Rondon, no centro da cidade. Sob uma perspectiva historiográfica, mas valendo-se do método etnográfico, as autoras apontam como essa área verde foi transformada e ressignificada a partir de usos e representações diversas ao longo da história local. Segundo as autoras, o bosque permeia a memória dos moradores mais antigos da região central de Londrina como um espaço que outrora 
serviu de suporte para a fruição da natureza e para uma vivência mais espontânea do lazer, remetendo a uma época em que a cidade era "tranqüila" e "pacata" e quando ali eram realizados almoços, piqueniques e passeios familiares. Contudo, desde as décadas de 1970 e 1980, quando comportou o Terminal Urbano de Londrina - posteriormente transferido para a Avenida Leste-Oeste -, o bosque passou a ser dividido entre os moradores do entorno e alguns atores sociais, como moradores de rua, usuários de drogas e prostitutas, vistos com maus olhos pelas famílias da região. Como constatam Almeida \& Adum, atualmente o Bosque Municipal Mal. Cândido Rondon transformouse em uma "ilha de lazer" no centro da cidade, que continua a ser freqüentada por criança e aposentados, mas com nítidas mudanças em seus hábitos cotidianos, sempre atentos às ameaças advindas do crescimento da cidade.

Este exemplo é importante na medida em que demonstra que a incorporação de certos hábitos e comportamentos na região central, sobretudo, em decorrência da prevenção às práticas ilícitas e violentas - como furtos, roubos e homicídios -, é uma tendência generalizada e que não se aplica apenas ao Bar Valentino, embora neste espaço ela tenha sido particularmente sintomática. Contudo, apesar das ressalvas adquiridas por parte de proprietários e frequientadores do espaço, a partir de artigos veiculados nos jornais locais percebe-se que as matérias com maior destaque sobre o bar aos poucos migraram dos cadernos de cultura para as páginas policiais, denunciando não apenas um aumento quantitativo de crimes, como também um agravante qualitativo, referente à ocorrência de interações sociais bastante violentas em suas proximidades como estupros e um novo homicídio em 2005. Como se observa a seguir:

Na madrugada deste domingo, 30, uma jovem de aproximadamente 18 anos foi assassinada em frente ao Bar Valentino, na Avenida Bandeirantes em Londrina. Ela conversava com o proprietário de um veículo Diplomata em frente ao bar quando dois rapazes encostaram uma arma na cabeça da jovem e atiraram a queima roupa. Ela teve morte instantânea. $\mathrm{O}$ rapaz que a acompanhava não foi atingido e contou à Polícia que combinava um 'programa' com a garota quando foi surpreendido pelos assassinos. A suspeita da Polícia é de que ela era 'avião', distribuía drogas a consumidores, e pode ter sido vítima de um acerto de contas. (Folha de Londrina, 31.01.2005: 11).

Casais de namorados que costumam freqüentar o Zerão (Área Central de Londrina) de madrugada devem tomar cuidado. Ontem, a Polícia Civil registrou um caso de estupro no local, que segue o padrão de outros 15 crimes ocorridos no Zerão no ano passado. A queixa foi 
formalizada por uma garota de 16 anos atacada por volta das 3 horas quando passeava com o namorado. [...] Não há uma descrição física precisa sobre o criminoso, As vítimas dizem apenas que ele possui sotaque local, é forte, tem cerca de 30 anos, e age com muita calma e frieza. 'Suspeitamos também que ele ficava em bares próximos, como o Valentino, observando os casais que iam namorar na região do Zerão', prosseguiu [Rui] Rebello [escrivão da $10^{\mathrm{a}}$ Subdivisão Policial]. O delegado Antônio do Carmo aconselha que as vítimas jamais deixem de denunciar estupros, para não facilitar a impunidade, e que casais evitem o Zerão em horários de pouco movimento (NAVARRO, 2005: 12).

Dentre a totalidade das entrevistas e conversas informais realizadas com proprietários, ex-proprietários, funcionários e freqüentadores do Bar Valentino, constatam-se duas explicações recorrentes para o sensível aumento da criminalidade e da violência em seus arredores, especialmente, nos últimos anos em que o espaço se manteve no centro da cidade. Direta ou indiretamente, os entrevistados invariavelmente associavam esta situação à "invasão" dos chamados "manos", que se apropriaram do bar em uma época mais recente, ou então a uma "coisa natural ao crescimento da cidade", que passou a acompanhar as tendências observadas em metrópoles consideradas violentas, como São Paulo e Rio de Janeiro.

Em muitos dos depoimentos onde os "manos" são apontados como os responsáveis por esta situação, estes grupos provenientes de bairros mais distantes e periféricos são identificados mediante fórmulas como "o pessoal dos bairros" que "invadiu o Valentino", que estão "perdidos no bar", ou ainda, que "não sabem o seu lugar". Neste sentido, é interessante observar que, apesar do Bar Valentino ser considerado por seus freqüentadores como um dos pontos de encontro mais tradicionais da cidade, nem sempre "[...] quando a cidade se encontra estão incorporados os excluídos e os que estão à margem dela. [Pois] Para as elites, os excluídos não são 'da cidade' ou 'a cidade'. Apenas estão na cidade" (FANTIN, 2000: 52). A seguir, destaco alguns depoimentos que associam diretamente os "manos" à violência e à criminalidade, sendo que no primeiro deles uma freqüentadora - jornalista, homossexual - foi questionada sobre algumas situações nas quais afirmou que não beijaria outras meninas no bar, enquanto que no segundo, o freqüentador - estudante de Artes Cênicas, também homossexual - foi questionado quanto à utilização do termo "barra pesada" para se referir ao Bar Valentino aos finais de semana: 
Olha, é pelos 'manos' mesmo que estão perdidos aqui. Porque eles ainda não sacaram que o negócio é se aceitar. Eles são aceitos aqui, mas eles não aceitam a gente. Então, fora eles, assim, ninguém vai olhar duas meninas se beijando e vai falar: 'Oh!'. Se eu tiver perto de um monte de 'mano' aqui no Valentino eu não beijo mesmo. Eu não beijo porque não é nem questão de preconceito, é questão de segurança. Porque eu já vi duas meninas se beijando e os caras falando: 'meu, para com isso! Como que vocês conseguem fazer isso? Deus me Livre!'. Eles ficam revoltados porque não é com eles, porque elas tão se beijando sozinhas. Agora, pelo povo do bar, eu beijaria tranqüilo. Porque o 'mano' você sabe que eles vão virar e falar: 'sua sapatão!'. Aí às vezes eu falo: 'o quê esse povo ta fazendo aqui perdido?' (Trecho de entrevista, 11.01.2005).

'Barra pesada' é quando baixa uma 'maloqueirada' dos bairros mais 'foda'. De sábado eu já vi até gente com revolver na cintura lá. Um em quem eu esbarrei naquele corredor lotado. Aí eu senti m negócio de ferro no meu braço e a hora que eu olhei era 'um puta revolver' na cintura do cara. Eu falei: 'caralho'! E se esse cara fica louco e resolve dar tiro pra cima!'. Quando você não tá muito bem, lá aumento o quê eu to sentindo. Se eu tô bem, lá tá maravilhoso, se eu to mal, lá também aumenta. Porque você pára e começa a observar o bar, você vê gente passando muita droga por baixo da mesa, você vê 'nego' caindo na escada de bêbado, você vê gente chorando. Então eu não dou muita conta disso no sábado. Mas de dia de semana é mais tranqüilo, porque tem um pessoal mais tranqüilo, mais 'cabeça aberta', que você não tem que ficar pensando: 'sumam daqui!' (Trecho de entrevista, 08.03.2005).

Muitos freqüentadores, sobretudo os mais antigos, também afirmam que com a "invasão" dos "manos" no final da década de 1990, o espaço vinha se "descaracterizando" pela perda de valores como a "liberdade" e a "espontaneidade". Esta situação é análoga àquela observada por Abreu (2005) em sua pesquisa sobre as raves na cidade de São Paulo, onde a autora constata que quando estas festas passaram a ser freqüentadas pelos "cybermanos" - apreciadores de música eletrônica provenientes das periferias da metrópole paulistana -, os ravers mais experientes passaram a afirmar nostalgicamente que a "vibe" ${ }^{37}$ havia acabado. Em ambos os casos, há uma associação entre a presença de classes populares e a "descaracterização" de ambientes inicialmente considerados por seus freqüentadores como livres e democráticos - que nos permitem questionar a concepção de "democracia” dos jovens provenientes das elites.

\footnotetext{
${ }^{37}$ Como afirma Abreu "não é tanto a euforia, mas a experiência de uma coletividade que melhor traduz a noção de vibe nas raves. Nesse contexto, a expressão se refere à alegria e ao conforto produzidos pela confraternização grupal, ou ainda, como comumente dito pelos ravers: 'a energia coletiva que é compartilhada"” (2005: 43).
} 
Além disso, a autora também analisa como o termo "cybermano" é uma articulação discursiva que delimita fronteiras simbólicas entre aquele que nomeia - e que se cria como "não-cybermano" - e os nomeados, construindo uma relação de hierarquização através do deboche e da conotação pejorativa. As observações de Abreu se aproximam bastante da "teoria de acusações" elaborada por Velho (2004), na qual o autor expõe duas categorias, "drogado" e "subversivo", que quando acionadas em situações de conflito acabam por explicar situações de desvio, rebaixando o acusado a uma posição desprivilegiada nas relações micro-políticas. No caso do Bar Valentino, da mesma forma que os termos pejorativos "cybermano", "drogado" e "subversivo" analisados por estes autores, a categoria "mano", quando acionada por seus freqüentadores, surge como um fator explicativo que resolve de forma imediatista a incidência dos crimes e ações violentas neste espaço, rebaixando e culpando os moradores das periferias por estes atos. No entanto, apesar da recorrência da categoria, seria precipitado associar diretamente os "manos", ou as classes populares, à incidência de crimes violentos nas imediações do bar. Afinal, conforme as já citadas análises de Caldeira (2000), em um contexto mais amplo, e as de Zequim (2004) e Carvalho (2008), em âmbito local, estes crimes estão associados a uma rede de ilegalidade que perpassa desde as elites e o próprio poder público até as camadas mais populares.

A segunda explicação observada nas entrevistas, na qual a criminalidade e a violência são percebidas como um fator "natural" ao crescimento da cidade, é um pouco mais próxima ao argumento defendido aqui. Mas ainda assim, cabem algumas ressalvas quanto à forma na qual essa associação surge na fala dos entrevistados. Pois, em primeiro lugar, não há uma correlação direta entre altas taxas de criminalidade e/ou violência e o tamanho da cidade; afinal, nem toda metrópole é necessariamente violenta, assim como não são todas as cidades pequenas e médias que podem ser consideradas como "tranqüilas" ${ }^{38}$. Além disso, avaliar altos índices de criminalidade e violência como fatores "naturais" e irreversíveis, independente do contexto, é uma posição demasiadamente conformista, que, certamente, desencadeia um ciclo de resignação que banaliza uma questão importante. Ainda, conforme a tendência apontada por Magnani (2006), certamente os depoimentos mostram-se permeados pelo discurso midiático, que

\footnotetext{
${ }^{38}$ A cidade de Porto Velho, capital de Rondônia, que pode ser considerada como um núcleo urbano de porte médio, com aproximadamente 369.345 habitantes possui uma taxa de 58, 07 homicídios por 100.000 habitantes, enquanto a metrópole de Sidney, capital do estado de Nova Gales do Sul, na Austrália, possui uma população aproximada de 4.198 .543 habitantes e possui uma taxa de 1,7 homicídios por 100.000 habitantes. (www.cedeplar.ufmg.br/pesquisas/pbh/arquivos/mod9parte7.pdf).
} 
através de indicadores sociais, econômicos e demográficos encara a dinâmica urbana unicamente a partir da ênfase em seus aspectos "desagregadores", disseminando, assim, uma inevitável sensação de "caos urbano".

Dadas estas ressalvas, nos depoimentos a seguir constata-se a associação entre o crescimento da cidade e o aumento da incidência das práticas violentas e ilegais nos arredores do Bar Valentino. O primeiro deles foi extraído da entrevista realizada com Jaiminho, proprietário do bar entre 1984 e 1986, enquanto o segundo refere-se à entrevista realizada com uma atriz e cantora que vivenciou os primeiros anos do bar, mudou-se para São Paulo e retornou a Londrina após quase vinte anos:

Na minha época não tinha isso não, esse pessoal, assim, esse pessoal que hoje se considera de periferia. A cidade cresceu e obviamente hoje é mais fácil de sair de lá e vir aqui pro centro da cidade. Até esses dias tavam falando aqui de um barzinho que tem na [Rua] Espírito Santo com a Paranaguá, que chama 'Varanda', que tava um problema sério ali porque tinha muita gente... Olha, não to reclamando do pessoal da periferia, mas o problema de roubo, de droga, você sabe que hoje acontece mais. Na nossa época tinha também, mas acho que a quantidade era bem menor. Hoje em dia rola muita droga, muita coisa. E esse povo 'de fora' [estudantes universitários] eu acho que traz um pouco isso. É esse o perfil, porque na nossa época também não tinha tanto jovem assim. Então eu acredito que tenha acontecido isso em função do crescimento, o crescimento da cidade mesmo. Só pode ser por causa disso. Porque também não foi só no Valentino, foi geral, né? E o Valentino é um bar famoso, que queira, quer não. Todo mundo fala do Valentino. 'Ah, eu já fui no Valentino, eu quero ir no Valentino'. Principalmente os jovens. (Trecho de entrevista, 29.01.2008).

Quando eu voltei pra cá há dois anos atrás, o Valentino tinha mudado muito. Ele tinha mudado, mas não espacialmente. Ele tava lá ainda na [Avenida] Bandeirantes. Mas tinha mudado muito os freqüentadores. Aí aconteceu o quê? Eu já não tinha mais vontade, já não me dava mais vontade de freqüentar enquanto ele tava ali. Aí, o quê eu descobri? O quê acontecia? Durante esses 20 anos, durante um determinado tempo eu acho que realmente ele continuava gostoso e tudo mais. Mas depois de um determinado tempo, eu acho que a cidade com... Com o crescimento da cidade, com as mudanças todas, o público foi mudando muito. Aí, realmente começou a me incomodar, assim, a frequiência das pessoas lá. E eu parei de ir. Porque começou a virar uma coisa... Quando eu voltei pra cá, tinha virado, sobretudo, com relação ao tráfico de drogas ali. Que é uma coisa sabida pela cidade toda, né? Inclusive pelo Chammé. A gente sabe disso, teve esse problema mesmo. O Chammé tentou por todas as vias solucionar, né? Mas quem é que consegue? Vide São Paulo, Rio de Janeiro. Quem é que pode? Então a coisa foi tomando uma proporção muito grande. $\mathrm{E}$ 
aí era ruim de ficar. E eu acho que o que aconteceu, nessa minha volta pra cá, é que se confundiu essa questão. Sobretudo, por causa dessa... Que na verdade não é só um problema de Londrina. É um problema de toda cidade grande. Na verdade é um problema do mundo atualmente. Que é essa questão da violência, da violência urbana. Essa questão das drogas desenfreadas, né? Mas a coisa foi por um outro lado. E o ambiente já não era mais uma 'janela pro mundo'. Pelo contrário, fecharam a janela e ficaram lá dentro escondidos. Virou um 'mocó' pros bandidos. (Trecho de entrevista, 23.02.2007)

Sobrepondo a revisão histórica apresentada no primeiro capítulo aos dados etnográficos expostos até aqui, de fato, é possível associar o aumento da incidência de crimes violentos nos arredores do Bar Valentino ao crescimento de Londrina. No entanto, tal associação não pode ser atribuída a uma relação "natural" e inevitável entre criminalidade e o tamanho da cidade, como a observada nos depoimentos acima, mas sim a uma especificidade dos centros urbanos que passam por processos de metropolização. Pois, como analisa Fantin (2000), no contexto do carnaval em Florianópolis, e Frúgoli Jr. (2000), no caso das disputas sócio-econômicas entre algumas áreas na cidade de São Paulo, a descentralização é uma das características metropolitanas, quando, em meio ao crescimento das cidades, o deslocamento das elites para novos "subcentros" normalmente é acompanhado pela dispersão da infra-estrutura viária, assim como de parte dos serviços e do comércio. Desta forma, o agravamento da situação nos arredores do bar, e em toda a área central de Londrina, é coincidente ao momento em que a cidade adentrou uma fase diferenciada de seu crescimento e expansão, descentralizando-se e ganhando certas características metropolitanas. Afinal, a partir de meados da década de 1990, com o desenvolvimento de potenciais "subcentros" em seu quadrante sul-sudoeste, para onde têm migrado as elites, houve também uma dispersão dos investimentos públicos e privados em saúde, educação e segurança pública, que certamente contribuiu para o aumento dos índices de criminalidade no centro da cidade, e, mais particularmente, nas proximidades do Bar Valentino.

Assim, neste capítulo foi apresentada a história do Bar Valentino, que em seus primeiros anos de funcionamento já construiu uma relação muito íntima com o desenvolvimento das manifestações artísticas locais, tornando-se um espaço fundamental para a consolidação de Londrina enquanto reconhecido pólo produtor e irradiador de artes no país. Pelas referências artísticas que lhe foram atribuídas, 
posteriormente o bar também passou a atrair um público heterogêneo, transformando-se em importante suporte para o encontro e a sociabilidade relativamente espontânea entre diversos grupos sociais. Também foi exposto que, por fatores como seu horário de funcionamento e sua localização na malha urbana, o Bar Valentino tornou-se um ponto de confluência entre alguns circuitos derivados em meio ao circuito de lazer noturno em Londrina. Pelas regularidades abstraídas nos deslocamentos de seus freqüentadores em seu trânsito mais amplo pela cidade, neste capítulo foi defendida a idéia de que os circuitos derivados que possuíam relações mais próximas com o bar se realizavam mediante os limites e as possibilidades impostas por uma cidade média, caracterizada por um centro único. Contudo, pelo significativo aumento nos índices de criminalidade em seus arredores, sobretudo nos últimos anos que precederam sua mudança de endereço, a análise do Bar Valentino no centro da cidade já permite constatar alguns aspectos da atual fase de crescimento e expansão de Londrina, especialmente no que se refere à descentralização do município - com a conseqüente dispersão dos investimentos em segurança na malha urbana -, e à incorporação de certos hábitos e costumes por parte de seus freqüentadores - como certas ressalvas diante dos crimes e da violência - em decorrência desta transição. 


\section{O NOVO BAR VALENTINO}

Assim como no capítulo anterior foram expostos dados etnográficos referentes à história do Bar Valentino e aos últimos anos em que o espaço esteve localizado no centro da cidade, nesta última seção apresentarei dados relativos à sua transferência de endereço e à forma como o bar passou a ser apropriado em sua nova localização. Mediante a comparação entre ambos os contextos, acredito que seja possível apreender o crescimento de Londrina através de um ângulo diferenciado. Pois, sob a perspectiva etnográfica aqui adotada, o cruzamento destas informações traz à tona aspectos deste processo - como a incorporação de certos hábitos e costumes, assim como a transformação nos padrões de interação social por parte da população local - que têm sido excluídos das análises realizadas em outras áreas acadêmicas.

\subsection{A Transferência do Bar Valentino: “... Da Força da Grana que Ergue e Destrói Coisas Belas"}

Os primeiros boatos acerca da possível mudança de endereço do Bar Valentino surgiram no segundo semestre de 2002. Conforme os rumores, o terreno onde o bar funcionava já há 23 anos, e que abrangia mais cinco residências ao redor, teria sido comprado por Galvão Bueno, famoso locutor esportivo da maior emissora televisiva do país, que pretendia construir ali um estacionamento vinculado a uma academia ou uma escola para futuras modelos e manequins. Ninguém sabia ao certo o que se instalaria no local, mas evidentemente isso implicaria no encerramento definitivo das atividades do Bar Valentino ou em sua transferência para outra área da cidade.

Entre meados de 2004 e o final de 2005, durante a pesquisa de Iniciação Científica que desenvolvia ali, ainda que este fato não estivesse diretamente relacionado ao tema do estudo, o episódio passou a surgir espontaneamente em diversas das entrevistas que realizei com os freqüentadores do bar. Na ocasião, pude observar que, apesar de algumas reportagens já terem sido veiculadas nos jornais locais anunciando a venda do terreno (SATO, 2003; 2004; BRIGUET, 2004; NAVARRO, 2004), os boatos não eram levados muito a sério, ainda que o fossem bastante recorrentes entre os 
usuários. Afinal, pelo perfil do comprador - considerada uma pessoa pública de personalidade peculiar, freqüente alvo de humoristas e imitadores em programas televisivos -, bem como por certa tradição do espaço enquanto palco de situações imprevisíveis e inusitadas, até uma data bem próxima à efetiva transferência de endereço a maioria dos freqüentadores ainda acreditava que essa era mais uma das inúmeras "lendas" 39 envolvendo o Bar Valentino, que de tempos em tempos se disseminavam por Londrina. Como se observa nos trechos a seguir, o termo "lenda" surgiu em várias entrevistas para caracterizar a situação:

Essa [história] é velha! Desde que eu saí de Londrina dizem isso. Eu tô em Curitiba faz dois anos e toda vez que eu venho pra Londrina eu vou no Valentino. Só que se fechar não vai mais 'rolar loucura'. E Londrina também já é meio 'foda' pra tocar, imagina sem o Valentino. Vai ser horrível. Porque lá é um espaço pras bandas, pra 'pirar o cabeção', se libertar no fim da noite. Mas eu ainda acho que é 'lenda' essa história de que vai fechar. (Trecho de entrevista, 24.11. 2005).

Meu, se o Galvão realmente comprou o terreno, o que eu acho que é 'lenda', ele deveria continuar com o bar. Porque isso vai dar mais lucro e menos dor de cabeça pra ele. Porque, 'na boa', se ele fechar aquilo, vai ter gente apedrejando ele na rua. Então eu acho que ele não vai ser tão burro. Mas, caso isso não seja 'lenda', eu acho que esse 'cara' devia se preocupar mais com a vidinha dele e ir fazer essa escolinha de modelos em outro lugar. Talvez na [boate] Fashion ou no Empório [Guimarães], que têm mais a ver com isso, né? (Trecho de entrevista, 22.11.2004).

Contudo, conforme decorriam os meses, os rumores tornaram-se mais consistentes, causando certo receio entre os freqüentadores mais assíduos do espaço. Apesar de não dispor de dados quantitativos acerca deste episódio, a partir das entrevistas e conversas informais realizadas, posso afirmar com certa segurança que

\footnotetext{
${ }^{39}$ Algumas das "lendas" criadas sobre o Bar Valentino em seus 28 anos de existência referem-se, por exemplo, à cartomante que residia aos fundos do espaço na época em que este foi inaugurado e que "costurou" o bar no solo para que ele nunca fosse fechado ou transferido para outro lugar. Há histórias também sobre o dia em que o fantasma de Rodolfo Valentino surgiu ali repentinamente, bebeu e saiu sem pagar a conta. Outros crêem que um gato que perambulava todos os dias pelos telhados do Valentino morreu de cirrose e desde então seu espírito continua por ali, mas em busca de um pires de leite. Estas "lendas" a respeito do Bar Valentino estão presentes na crônica "O Tempo de um Bar" (BRIGUET, 2004), publicada no Jornal de Londrina do dia 10 de outubro de 2004, quando o espaço completou 25 anos. Ainda que absurdas tais "lendas" são frequentemente lembradas de forma bem humorada pelos usuários mais antigos do Bar Valentino.
} 
uma pequena parcela dos usuários se posicionou favorável à possível transferência de endereço - principalmente, pelo sensível aumento nos índices de criminalidade e de relações sociais violentas nos arredores do bar -, enquanto a grande maioria dos freqüentadores parecia ser contrária à provável mudança: pois, esta parcela acreditava que possivelmente o Bar Valentino seria descaracterizado, tanto pela perda da casualidade proporcionada pela casinha de madeira, como também pela probabilidade de sua transferência para uma área mais afastada ao centro da cidade.

Em $1^{\circ}$ de abril de 2006, a compra do terreno pelo empresário Heraldo Soares sogro de Galvão Bueno - e a conseqüente mudança do Bar Valentino tornaram-se públicas a partir de uma entrevista concedida por seu proprietário a um jornal local. $\mathrm{O}$ bar seria transferido da esquina entre a Avenida Bandeirantes e a Rua Jorge Velho, na região central, para a esquina entre as ruas Joaquim Nabuco e Prefeito Faria Lima, em um bairro relativamente nobre, numa área liminar entre o centro e as zonas sul-sudoeste da cidade. Na referida entrevista, Waldomiro Chammé aponta que a escolha do novo local esteve associada não apenas às restrições impostas pela lei de zoneamento - que impedia a transferência para os espaços procurados inicialmente -, como também à parceria proposta por uma construtora, que, além de oferecer o terreno, ainda arcaria com alguns custos do imóvel. Pois, como afirmou o proprietário, mediante esta parceria o Bar Valentino integraria um projeto futuro da construtora que "[...] depois, continuaria essa obra, fazendo outros imóveis comerciais na mesma área, com uma área de estacionamento que [serviria] para o Valentino e para as lojas que se [instalassem] no local" (BRIGUET, 2006: 10).

No entanto, pela própria demanda de parte dos freqüentadores, e, certamente, por objetivos comerciais, que tornariam a mudança menos impactante, a casinha de madeira que há 27 anos servia de suporte ao Bar Valentino seria desmontada e reconstruída no novo endereço. Além disso, o espaço também passaria a contar com um amplo estacionamento, assim como com mais um ambiente - com cerca de $200 \mathrm{M}^{2}$, em alvenaria e com isolamento acústico, equipado com um palco de $30 \mathrm{M}^{2}$, camarins, pista de dança e sanitários exclusivos - para a realização dos shows e demais eventos artísticos, já que, segundo o proprietário entrevistado: 
O bar sofreu uma mudança nos últimos tempos. Passou a ser uma casa de shows, sem estar preparado pra isso. Para os habitués que queriam tomar uma cervejinha ou escrever as memórias no balcão, essa história de shows atrapalhava um pouco. Agora vamos ter dois ambientes, e poderemos atender ao público dos shows e ao público do bar. A gente pode até recuperar aqueles clientes que estão a fim de chegar ao bar, tomar uma cerveja, comer um macarrão e ouvir jazz (BRIGUET, 2006: 10).

As estratégias relativas à reconstrução da casa de madeira e à anexação de um espaço mais apropriado para a realização dos eventos artísticos, de fato, tornou a mudança do Bar Valentino um pouco menos impactante. Muitos freqüentadores passaram a encarar este episódio de maneira positiva, sobretudo, pela perspectiva de maior conforto e diminuição da violência. Apesar disso, a parcela de usuários que se posicionava contrária à mudança iniciou uma série de iniciativas que marcavam sua insatisfação com a situação, principalmente, através de manifestações na internet: esboçaram-se protestos e tentativas de tombamento do bar como patrimônio histórico estadual, especialmente, através do site de relacionamentos "orkut.com" ${ }^{40}$; foram veiculados alguns artigos acerca deste episódio nos jornais locais (BRIGUET, 2006; NASCIMENTO, 2006), na mídia independente e em alguns blogs ${ }^{41}$; vídeos foram produzidos para acesso público no site "YouTube.com" ${ }^{42}$; além de uma iniciativa isolada, porém muito expressiva, quando em certa manhã o muro do Bar Valentino amanheceu pichado com a inscrição “... Da Força da Grana que Ergue e Destrói Coisas Belas" ${ }^{43}$.

A seguir, reproduzo um trecho referente às diversas tentativas de articulação, a partir do site "orkut.com", a fim de tombar o Bar Valentino como patrimônio cultural:

\footnotetext{
${ }^{40}$ Neste site de relacionamentos, além de algumas comunidades dedicadas às noites específicas do Bar Valentino, como a "Raw Power", a "Noite Latina", a "Noite do Charuto Cubano" e a "Terça Tilt", existem também duas comunidades mais diretamente relacionadas às discussões sobre o espaço. Uma delas conta atualmente com 1.402 usuários cadastrados e a outra com expressivos 6.384 membros. Estas comunidades encontram-se acessíveis no endereço eletrônico www.orkut.com.

${ }^{41}$ São conhecidos por blogs, diários virtuais, de acesso público, mantidos na internet.

${ }^{42}$ Disponíveis para visualização nos endereços eletrônicos http://www.youtube.com/watch?v=B_v2HN7n1ZY e http://www.youtube.com/watch?v=mHH1YOAH618\&mode=related\&search=.

${ }^{43}$ Em referência à música "Sampa", de Caetano Veloso, presente em seu disco "Muito" (1978).
} 


\section{Para onde vai o Valentino??? :}

Ei, pessoal... Se realmente o Valentino vai mudar de lugar, para onde você gostaria que ele fosse?

\section{Tombado! :}

Eu acho que o bar deveria ser tombado como patrimônio histórico de Londrina! Assim não poderia ser destruído! Vamos lançar um abaixoassinado. Quem apóia?

Abaixo-assinado na veia! :

Eu assino para o 'Vale' continuar do mesmo jeito que tá!

\section{Eu assino! :}

Mas quem poderia tomar a frente?

Abaixo-assinado é o caralho! :

Acho que a gente tem que partir pra uma ação mais violenta. Vamos encher o Galvão [Bueno] de porrada!

\section{Concordo:}

O Galvão Bueno tá zuando a nossa cidade!

\section{O Valentino não pode mudar!!! :}

Ele sempre foi legal ali e sempre tem que ser. Se for pra outro canto não vai mais ter graça. Aquele lugar é mágico e, se o Galvão [Bueno] construir um estacionamento lá, eu vou riscar todos os carros! Esse abaixo-assinado é uma boa idéia, mas vai ser uma parada dura da gente ganhar. Ainda mais quando se trata das cifras do Galvão Bueno.

Como é possível perceber no trecho acima, parte dos freqüentadores que participava das discussões atacava Galvão Bueno de forma bastante ofensiva em meio à crença de que o locutor esportivo seria o responsável direto pela compra do terreno. Tais ataques e ofensas não se limitaram ao referido site de relacionamentos, mas também se estenderam aos diversos blogs mantidos na internet pelos usuários do Bar Valentino, onde seus autores incitavam os demais freqüentadores a se manifestar, por exemplo, através de pequenos atos ou cantando músicas de protesto. Como se constata nos trechos a seguir:

O Valentino vai fechar e vai existir uma academia masculina no terreno que foi comprado pelo Galvão Bueno. Não pode! Não pode! Não pode! 'Porra'! Ninguém se manifesta nessa cidade? É o nosso bar. O bar 'para quem está in, out, up and down'. O bar de todas as pessoas, de 'todas as tribos'. Para onde vai aquele povo? Que outro bar em Londrina absorverá tamanha diversidade da fauna humana? Homens que gostam de homens e os que gostam de homens que parecem mulheres. Mulheres que gostam de mulheres e homens. Homens que curtem ser mulheres. Mulheres que querem ser homens, 
homens e mulheres que se gostam. Mulheres e homens que não gostam de ninguém, nem de si mesmos. O bar tem mais de vinte anos e sempre foi assim. A parede torta, a casa de madeira, o macarrão, o balcão. Os verdadeiros freqüentadores do bar devem ir dormir lá! Acampar em frente, fazer uma corrente de pessoas e proibir a invasão do Galvão. Aquele sujeito chato, que não tem nada a ver com Londrina. Ontem eu fui ao Valentino e pode ter sido a última vez! E como protesto, após desistir da idéia de tirar a roupa e subir na mesa, eu roubei um cardápio. Faça a sua parte: DIGA NÃO AO GALVÃO!

Fiz uma música pra galera cantar nesses que podem ser os últimos dias do Valentino:

Essa porra vai fechar

Olé, olé, olá

Essa porra vai fechar

Olé, olé, olá

E vão derrubar

Então, rema, rema remador

Pau no cu do locutor

E se o locutor for vigarista

Pau no cu do comentarista

Mas, ainda que todas estas iniciativas tenham contribuído para sensibilizar os proprietários do espaço quanto à reconstrução da casa de madeira, elas não foram suficientes para impedir a mudança do Bar Valentino. A transferência fora, então, planejada de forma que o bar não encerrasse suas atividades, ainda que provisoriamente, em decorrência de sua transição. Pois, no período em que a casinha seria desmontada e reconstruída no novo terreno - de julho a setembro de 2006 -, o bar funcionaria temporariamente apenas no novo ambiente destinado às apresentações artísticas nomeado pelos proprietários de "Clube Valentino", e que posteriormente passou a ser chamado pelos freqüentadores de "salão" ou "ambiente da boate".

Assim, no dia 26 de junho de 2006, ao mesmo tempo em que se iniciou o processo de transferência da casinha de madeira, foi inaugurado o "Novo Valentino", ou o chamado "Clube Valentino", que em suas primeiras noites de funcionamento já mostrou notável ampliação de seu público, além de mudanças marcantes no próprio conceito do bar. Afinal, apesar de continuar priorizando e apoiando o desenvolvimento das manifestações artísticas na cidade, o espaço, antes caracterizado pela atmosfera e por certa estrutura underground, ganhou contornos mais comerciais, assemelhando-se muito a uma convencional boate. Por este fato, assim como por sua nova localização na malha urbana, muitos freqüentadores de casas noturnas marcadamente mais elitizadas, e 
que no contexto anterior poderiam ser consideradas como opostas ao Bar Valentino como os bares "Escritório" e "Pau-Brasil", as boates "Vega" (antigo "Todas as Tribos"), "Joy" (antiga "Fashion”), "Acústico" e "Empório Guimarães", a "Choperia Fábrica I" e a conveniência "Pátio San Miguel" -, passaram a dividir o espaço com seus antigos freqüentadores.

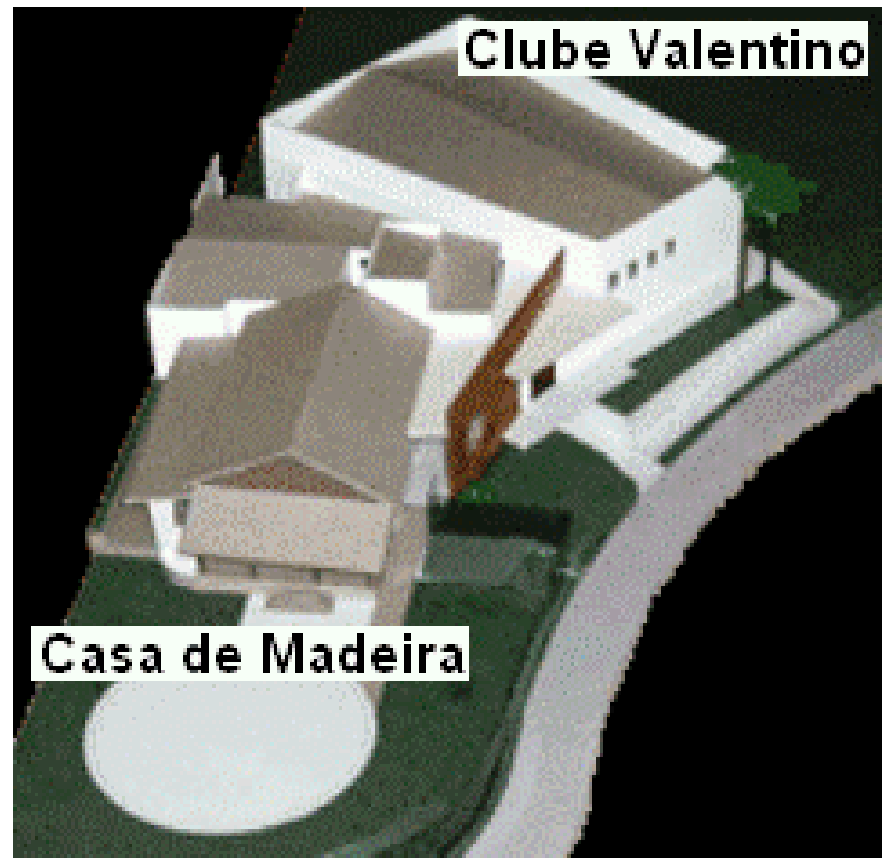

Ilustração 5. Maquete do Novo Bar Valentino, com a casa de madeira já anexada ao "Clube Valentino".

Fonte: www.barvalentino.com.br; editado pelo autor.

Enquanto as primeiras noites do "Clube Valentino" dividiam as opiniões dos freqüentadores mais antigos - que aprovavam o novo espaço, pelo maior conforto e pela segurança proporcionados, ou, ao contrário, o reprovavam pelo ambiente ter se transformado em "uma boatinha, invadida pelo pessoal do Empório Guimarães" -, as obras de transposição da casinha de madeira prosseguiam. A transferência iniciou-se pela retirada das telhas, do forro e das juntas da velha casinha. Em seguida, as paredes foram desmontadas e cada tábua recebeu um número, de forma que posteriormente, no novo endereço, estas fossem recolocadas em sua posição inicial. Como em casos como este normalmente $30 \%$ da madeira original é perdida (BRIGUET, 2006), o material comprometido foi substituído por sobras de demolição recolhidas em sítios da região. Neste processo, foram poucas as modificações em relação à antiga casinha, com 
destaque para o reposicionamento dos banheiros e para a alteração do balcão, que voltou à mesma posição que ocupava anteriormente às reformas de $1998^{44}$.

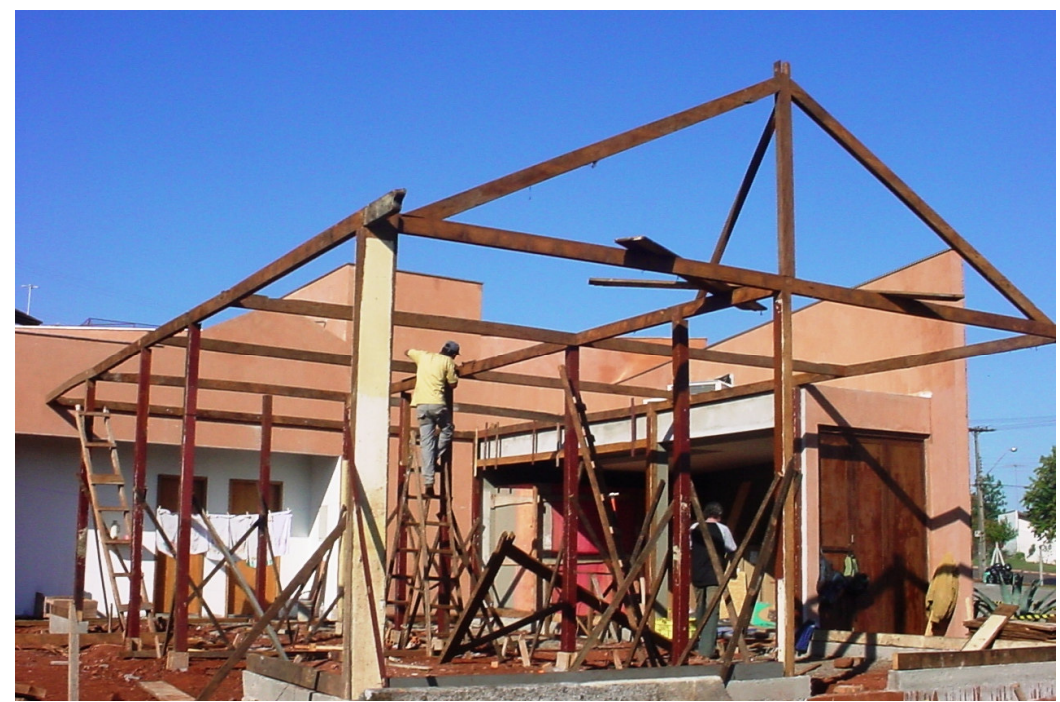

Foto 8. Reconstrução da casa de madeira no novo endereço do Bar Valentino Fonte: Carla Caíres (Diretoria de Patrimônio Artístico e Histórico-Cultural de Londrina).

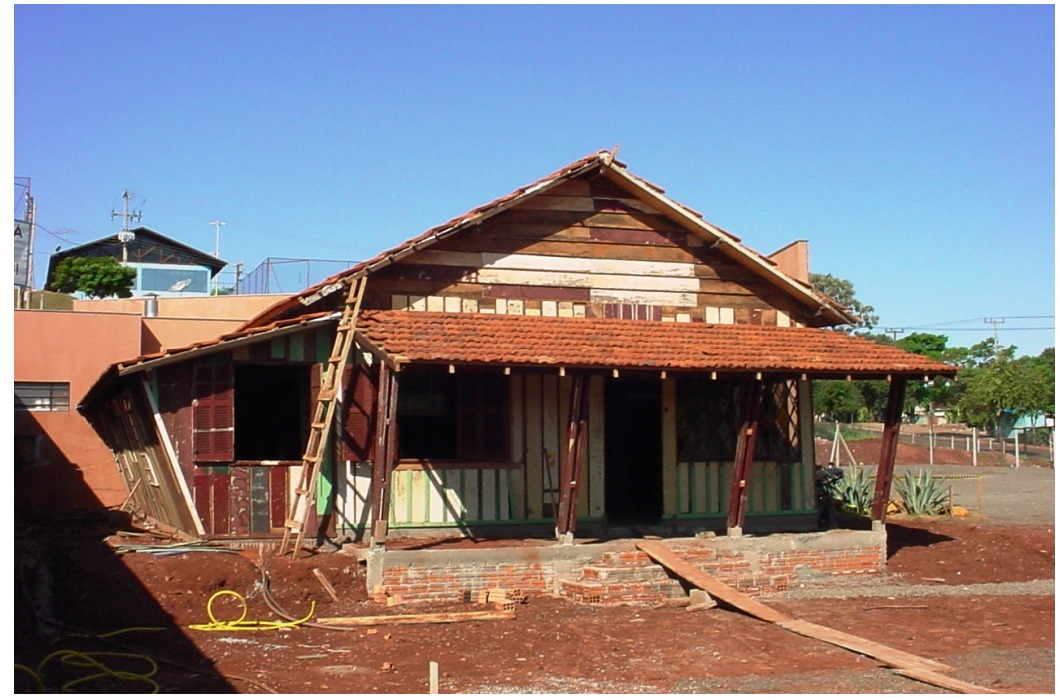

Foto 9. Reconstrução da casa de madeira no novo endereço do Bar Valentino Fonte: Carla Caíres (Diretoria de Patrimônio Artístico e Histórico-Cultural de Londrina).

44 A transferência da casinha de madeira que servia de suporte ao Bar Valentino ficou sob a responsabilidade do artesão Poka Marques, que contou com a assessoria técnica do arquiteto Antônio Carlos Zani. Além dos profissionais responsáveis pela parte técnica da transposição, todo o processo de transferência fora registrado pelos fotógrafos Saulo Ohara e Iara Strobel, assim como por profissionais da Diretoria de Patrimônio Artístico e Histórico-Cultural da Secretaria Municipal de Cultura. 
Aproximadamente três meses após a inauguração do "Clube Valentino", no dia 29 de setembro de 2006, com a realização do evento "Chilli com Jazz", foi reinaugurada a casinha de madeira no endereço ocupado atualmente pelo bar. Desde então, como previra seu proprietário, além de absorver um número expressivo de novos freqüentadores, o Bar Valentino também recuperou muitos dos "dinossauros" que haviam abandonado o espaço em seus últimos anos, sobretudo, em decorrência do aumento nos índices de criminalidade. Como se observará na próxima seção, vários destes usuários mais antigos passaram a considerar que, com a reinauguração da velha casinha, o "clima" dos "bons anos do antigo bar" fora retomado. Então, se alguns freqüentadores - especialmente aqueles radicalmente contrários à mudança - encararam a transferência do Bar Valentino como a perda de um espaço significativo para a cidade, vários outros voltaram, ou passaram, a freqüentá-lo, reconquistando ou ganhando uma nova opção de lazer em Londrina.

\subsection{O Novo Bar Valentino e a Reconfiguração dos Circuitos}

\subsubsection{O Novo Bar Valentino: "Balada” na Boate, Boemia na Casinha e o Controle Associado à Segurança}

O Novo Bar Valentino está localizado em uma área da malha urbana de ocupação relativamente recente, que passou a ser habitada mais efetivamente a partir da década de 1970 sob o impulso dado com a construção da Universidade Estadual de Londrina na zona sudoeste da cidade. Trata-se de um bairro com ruas largas, tranqüilas e arborizadas, ocupado por famílias e estudantes de classe média e média alta. Não muito distante dali, no sentido sul-sudoeste, encontram-se bairros como a Gleba Palhano, o Jardim Petrópolis e o Parque Guanabara, que - conforme o "Gráfico 01", exposto no primeiro capítulo desta dissertação - figuram entre as áreas mais valorizadas de Londrina entre os anos de 1997 e 2005. Por sua proximidade a estes bairros, a via onde está localizado o Novo Bar Valentino - a Rua Prefeito Faria Lima - também tem 
sido bastante valorizada nos últimos anos, contando atualmente com um número crescente de empreendimentos residenciais, comerciais e de serviços em curso ${ }^{45}$.

Contudo, pelo próprio processo de valorização desta via, é notável a quantidade de "vazios urbanos", frutos da especulação imobiliária, em seus arredores. Desta forma, conforme a terminologia proposta por Magnani (2000) no âmbito da Antropologia Urbana, é possível afirmar que em meio à elevada quantia de "vazios urbanos", especialmente durante as madrugadas, a Rua Prefeito Faria Lima se constitui como um pórtico que liga a região central da cidade às imediações da Universidade Estadual de Londrina. Pois, para o referido autor, os pórticos são aqueles:

[...] espaços, marcos e vazios na paisagem urbana que configuram passagens. Lugares que já não pertencem ao pedaço ou mancha de cá, mas ainda não se situam nos de lá; escapam aos sistemas de classificação de um e outra e, como tal, apresentam a 'maldição dos vazios fronteiriços'. Terra de ninguém, lugar do perigo, preferido por figuras liminares e para a realização de rituais mágicos - muitas vezes lugares sombrios que é preciso cruzar rapidamente, sem olhar para os lados... (MAGNANI, 2000: 45. Grifos do autor).

Por este fato, mas também por sua localização mais afastada ao centro da cidade, se anteriormente cerca de $70 \%$ dos freqüentadores se dirigiam a pé ao espaço - como estimou o proprietário do Bar Valentino em entrevista concedida ao Jornal de Londrina (NAVARRO, 2004) -, atualmente, são poucos aqueles que se aventuram em caminhar pelas ruas desertas e escuras que envolvem o bar. A grande maioria dos usuários recorre agora ao transporte automotivo, seja por meio de veículo próprio ou por alternativas coletivas, como ônibus, táxis e, principalmente, as caronas previamente combinadas com amigos e colegas. Assim, para a maior parte dos que chegam ao Novo Bar Valentino, existem duas possibilidades: os automóveis podem ser parados na rua, geralmente próximos ao bar, ou guardados no estacionamento. Mas pela penumbra que recobre as vias mais próximas, em decorrência da arborização, e pelo elevado número de terrenos vazios nos arredores, que causam certa sensação de insegurança, poucos preferem a primeira opção ${ }^{46}$.

\footnotetext{
${ }^{45}$ Como dois loteamentos destinados às classes média e média alta; o novo campus da Faculdade Arthur Thomas; o laboratório do Centro Universitário Filadélfia (UNIFIL); os bares "Paiol" e "Estação Café Brasil"; e a boate "Vega", além do próprio Bar Valentino.
} 


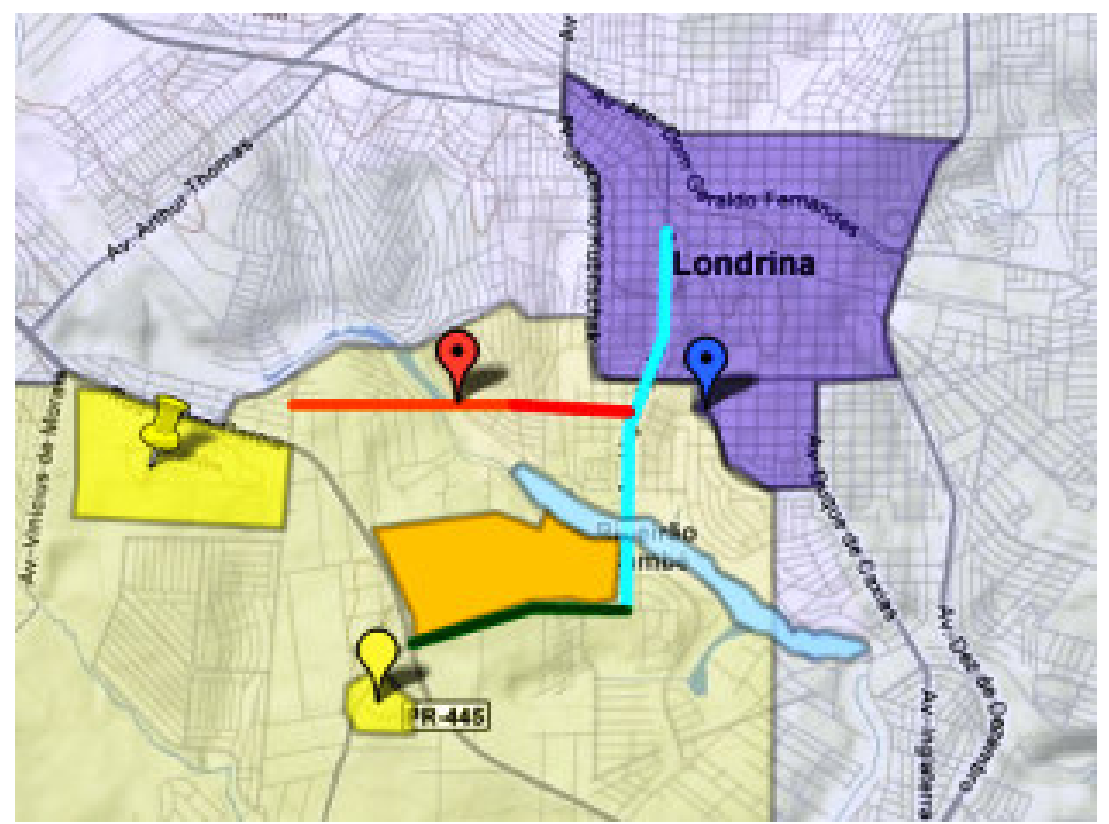

\section{Centro Expandido}

Zonas Sul-Sudoeste

Gleba Palhano - Área de Maior

Valorização do solo entre 1997 e 2005

Universidade Estadual de Londrina

$\bigcap$ Catuai Shopping Center

Bar Valentino (1979 -2006)

Novo Bar Valentino

Rua Humaitá

Rua Prefeito Faria Lima

Avenida Higienópolis

Av. Madre Leônia Milito

Ilustração 6. Antiga e atual localização do Bar Valentino.

Fonte: www.google.maps; editado pelo autor.

Os usuários que optam pelam "garantia" do estacionamento, antes de adentrarem ao bar, devem aguardar com seus automóveis em uma guarita - que interrompe o alambrado que cerca toda a extensão do Novo Valentino -, para o pagamento obrigatório e antecipado da taxa de $03 \mathrm{R}$ \$. Após a transação, é recebido um ticket que deve ser apresentado na saída, na mesma guarita, para a liberação do veículo. Especialmente aos finais de semana, os que chegam mais tarde - por volta das 00h, 00h30, quando o estacionamento já está quase lotado - não possuem alternativas além

\footnotetext{
${ }^{46}$ Em uma das primeiras ocasiões em que realizei pesquisa de campo no Novo Bar Valentino - em uma terça-feira, quando ocorreria a noite temática "Valentino Eletrônico" -, em companhia de uma amiga que havia me oferecido carona, fui surpreendido ao encontrar o estacionamento já lotado por volta das $23 \mathrm{~h} 20$. Sem alternativa, estacionamos o veículo em uma das ruas laterais ao bar, perpendicular à Rua Prefeito Faria Lima. Quando mal havíamos saído do automóvel, fomos abordados por uma dupla de policiais civis que nos orientaram a aguardar que uma das vagas do estacionamento fosse liberada, pois "estavam ocorrendo muitos arrombamento e assaltos naquele local".
} 
da área reservada ao serviço de manobrista. Embora o valor da taxa seja o mesmo do setor "comum", esta área é sempre a última a ser ocupada, sobretudo, pela desconfiança dos frequientadores em deixar as chaves de seus automóveis com os funcionários do bar. No entanto, se a fatalidade do setor de manobristas é vista com certo pesar pelos usuários, isso também lhes traz certa satisfação: pois, pela ausência de vagas no estacionamento, este é um dos indicativos de que já encontrarão "casa cheia" logo que adentrarem aos ambientes que compõem o Novo Bar Valentino.

Estacionados os automóveis, obrigatoriamente, todos os usuários devem dirigirse à fila que precede a entrada do bar. Como no caso do estacionamento, a fila também funciona como "termômetro", indicando se o espaço está "bombando" ou, ao contrário, se está "caído" - ou seja, "vazio". Além disso, como demonstram Clara Azevedo e Ana Luíza Borges (MAGNANI, 2005), em sua pesquisa etnográfica sobre a manha de lazer da Vila Olímpia, em São Paulo, e Almeida (2000), em sua etnografia sobre o circuito de cinemas paulistanos, em determinados espaços de lazer as filas possuem ainda outra função: pois são ocasiões para seu freqüentador "exibir-se, classificar e comparar, [cumprindo] mais do que o mero papel de esperar a vez de entrar". (MAGNANI, 2005: 186). De fato, no que se refere ao Novo Bar Valentino, as filas permitem que sejam avistados os primeiros conhecidos entre os grupos de usuários; ali também são trocadas informações sobre o DJ, a banda ou o grupo de teatro que se apresentará naquela noite; e, principalmente entre as garotas, são estabelecidas as primeiras relações de identificação ou alteridade, através do elogio ou da crítica à combinação das roupas, à maquiagem e ao penteado das demais freqüentadoras. Nas filas também ocorrem os primeiros flertes e paqueras, e, em algumas vezes, as primeiras situações de conflito da noite, sobretudo, entre os que aguardam ansiosamente o momento da entrada e os "furadores de filas".

Após alguma espera na fila, defronte à única porta de entrada e saída do Novo Bar Valentino, o usuário é "recebido" por um trio de seguranças - normalmente dois homens, trajando terno, e uma mulher. Um dos homens sempre ocupa quase toda a extensão da porta, de braços cruzados e semblante sério, intimidando com a postura e o olhar aqueles freqüentadores que porventura pensem em despistar a burocracia e o ritual de entrada ao novo bar. O outro se encarrega de revistar, apenas os rapazes, e, a partir do crivo do "detector de metais", eliminar qualquer dúvida quanto a existência de armas escondidas em meio ao casaco ou à calça dos usuários. A segurança feminina, por sua 
vez, munida de uma pequena lanterna, confere as bolsas das meninas, mais à procura de drogas ou garrafas de bebidas do que em busca de alguma espécie de arma.

Já no interior do Novo Bar Valentino há um hall que funciona como um espaço de transição entre a casinha de madeira e a "boate" - como os freqüentadores convencionaram a chamar o "Clube Valentino". Por não pertencer a nenhum destes dois ambientes este espaço pode ser considerado como uma área "neutra", destinada ao fluxo e à passagem; pois dificilmente vêem-se pessoas conversando, dançando ou bebendo por ali. Adentrado este hall, o usuário é orientado a dirigir-se a um balcão, onde permanecem dois ou três funcionários encarregados de efetuar um cadastro composto por dados como o nome, telefone, endereço e número de sua cédula de identidade. Além do referido balcão, este ambiente também possui um caixa, destinado àqueles que na saída preferem encerrar a conta com cartão de crédito; um banco rústico, em madeira, onde normalmente sentam amigos e colegas dos freqüentadores que estão na fila do caixa; além de três banheiros - um masculino, um feminino e outro reservado a portadores de deficiência física. Os únicos objetos de decoração são alguns vasos, um pequeno espelho na parede e um mural, onde são afixados avisos e cartazes com as próximas atrações do bar.

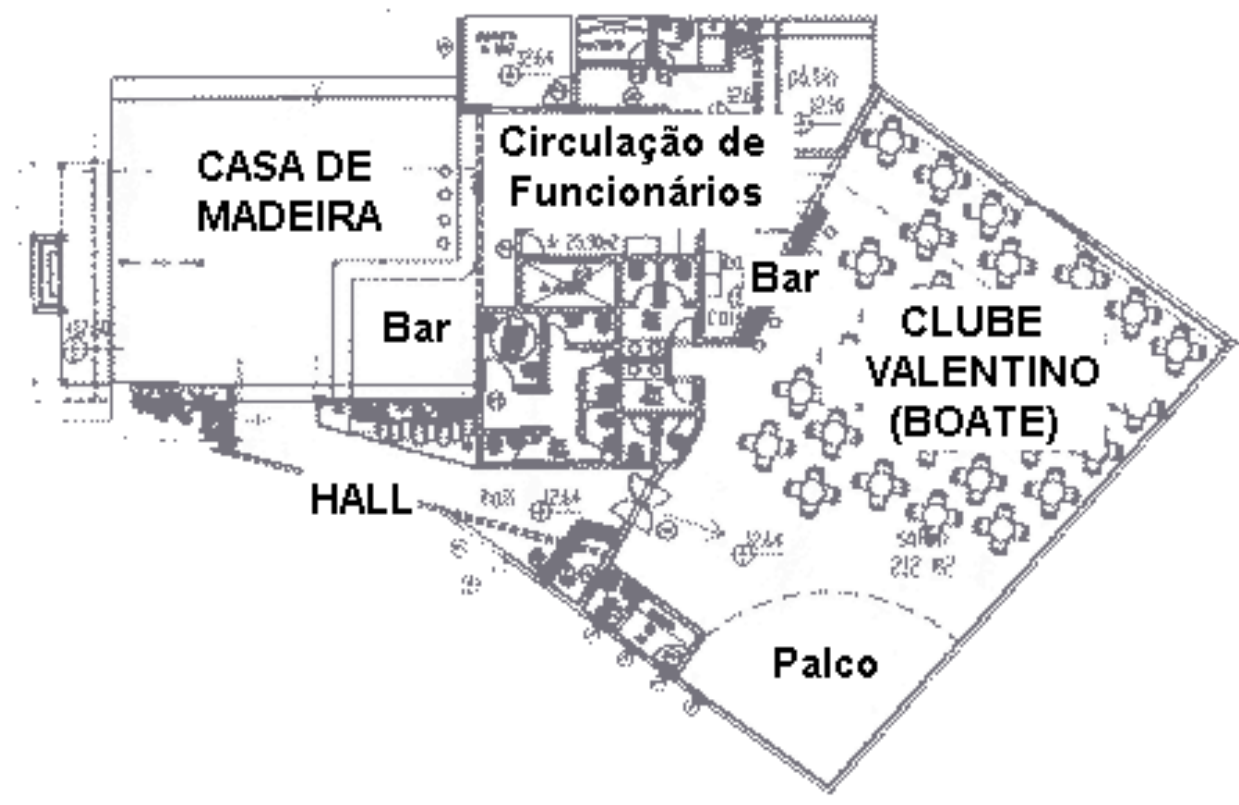

Ilustração 7. Planta baixa do Novo Bar Valentino Fonte: $\underline{w w}$.barvalentino.com.br; editado pelo autor. 
Ainda neste hall, nos dias em que são realizados peças teatrais ou shows musicais, o usuário deve escolher se permanece na casinha, mediante o pagamento de uma taxa de $03 \mathrm{R} \$$, até o término do evento - por volta da $1 \mathrm{~h} 30$, quando a entrada na boate é liberada a todos -, ou se acompanhará as apresentações artísticas no "Clube Valentino", desembolsando um couvert que oscila entre 07 e 10 R \$, dependendo da atração. No primeiro caso, o freqüentador recebe um cartão de consumação de cor preta, e no segundo um de cor vermelha. Pois, isso permite que, durante os eventos, os funcionários da boate identifiquem e restrinjam a entrada daqueles que pagaram apenas a taxa de permanência na casinha. Além desta função, tais cartões também integram um sistema informatizado, através do qual funcionários e proprietários têm acesso a dados que perpassam desde a quantidade de drinks e cervejas consumidas pelos usuários até as informações obtidas por meio do cadastro. Nas noites animadas apenas pelos DJs, os preços e os cartões de consumação são os mesmos para ambos os ambientes, assim como não há nenhuma restrição quanto ao trânsito entre a boate e a casinha.

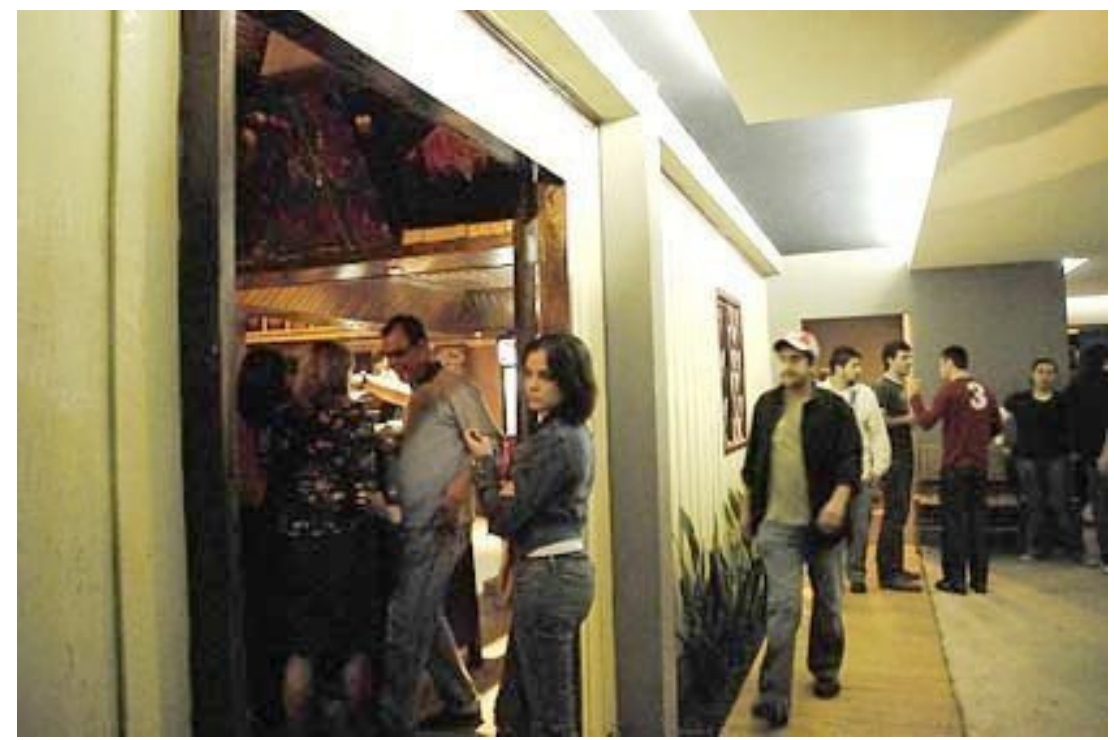

Foto 10. Vista do hall do Novo Bar Valentino a partir da entrada da casinha. Fonte: Acervo pessoal do autor.

Após todo este procedimento, composto pelo pagamento do estacionamento, pela espera na fila, pela efetuação do cadastro e pelo recebimento do cartão de consumação, finalmente, os usuários se dirigem ou à boate, ao lado direito, ao à casinha, ao lado esquerdo do hall. Se a opção for pela boate, após passar por duas portas largas, com isolamento acústico, os freqüientadores se deparam com um amplo salão à meia luz, 
equipado com aproximadamente trinta mesas, em madeira, agrupadas aos fundos e à frente do espaço - de forma que sua área intermediária permaneça livre, funcionando como pista de dança. Neste ambiente também não existem janelas, divisões internas ou artigos de decoração, afora um armário rústico, próximo ao bar, onde são guardados alguns copos; um pequeno balcão, que acompanha toda a extensão de uma das paredes, para que sejam apoiados copos, garrafas e bolsas; e uma grande pintura retratando o ator Rodolfo Valentino travestido de sheik. Em oposição à relativa calmaria da casinha, é ali onde realmente "fervem" as noites do Bar Valentino.

Quando são realizados shows musicais, mostras de filmes ou peças de teatro, os freqüentadores se portam de maneira relativamente comportada, dançando tranquilamente ou acompanhando atentamente os eventos em suas mesas. Contudo, ao final das apresentações, ou nas ocasiões em que a noite é embalada apenas pelos DJs, aos poucos os usuários vão deixando seus lugares em direção à pista de dança, onde o importante é se destacar: seja arriscando passos mais sensuais, formando "rodinhas" marcadas pelas coreografias, cantando as músicas de maneira bastante entusiasmada ou até mesmo arriscando brincadeiras como "trenzinhos", "pula cela" e a "dança das cadeiras". Entretanto, diferentemente de outros tempos, agora a espontaneidade do público parece estar mais associada à euforia proporcionada pela seleção musical e pela grande aglomeração de pessoas do que à intensa atmosfera artística que outrora envolvia o bar.

Além da pista de dança, este ambiente possui ainda dois elementos fundamentais: o bar e o palco. O bar, posicionado em uma das paredes laterais da boate, se destaca por sua iluminação, que contrasta com a meia luz da pista de dança, e é equipado com um caixa, um balcão, uma pia, alguns frízeres e prateleiras onde são guardados copos e garrafas de bebidas. Nas noites mais movimentadas, ali permanecem quatro ou cinco funcionários, sempre trajando camisetas pretas e aventais, também pretos, que em sua estampa imitam um fraque com uma gravata borboleta - em alusão a um dos figurinos mais característicos do ator italiano que nomeia o Bar Valentino. Estes funcionários se dividem entre tarefas como registrar os pedidos no cartão de consumação, encaminhar alguns destes pedidos à cozinha, preparar drinks e lavar copos. Apesar de em algumas noites o ritmo de trabalho beirar o frenesi, contrariamente aos seguranças, as relações que estes funcionários mantêm entre si e com os clientes mais antigos são sempre marcadas pelas bravatas e piadas. Para sustentar o bom humor, 
alguns deles mantêm seus próprios drinks em posições estratégicas no interior do balcão, meio às escondidas, para bebericarem ao longo da noite.

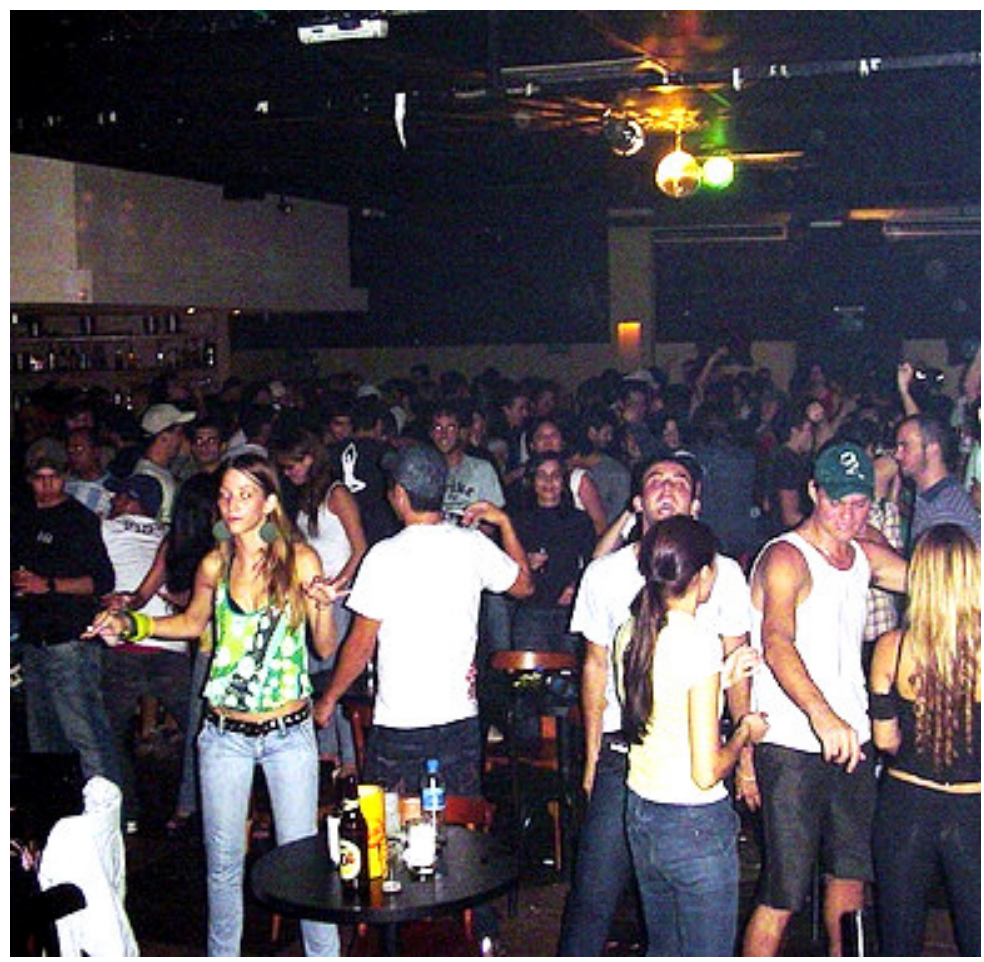

Foto 11. Pista de dança do Novo Bar Valentino vista do palco. Fonte: Acervo pessoal do autor.

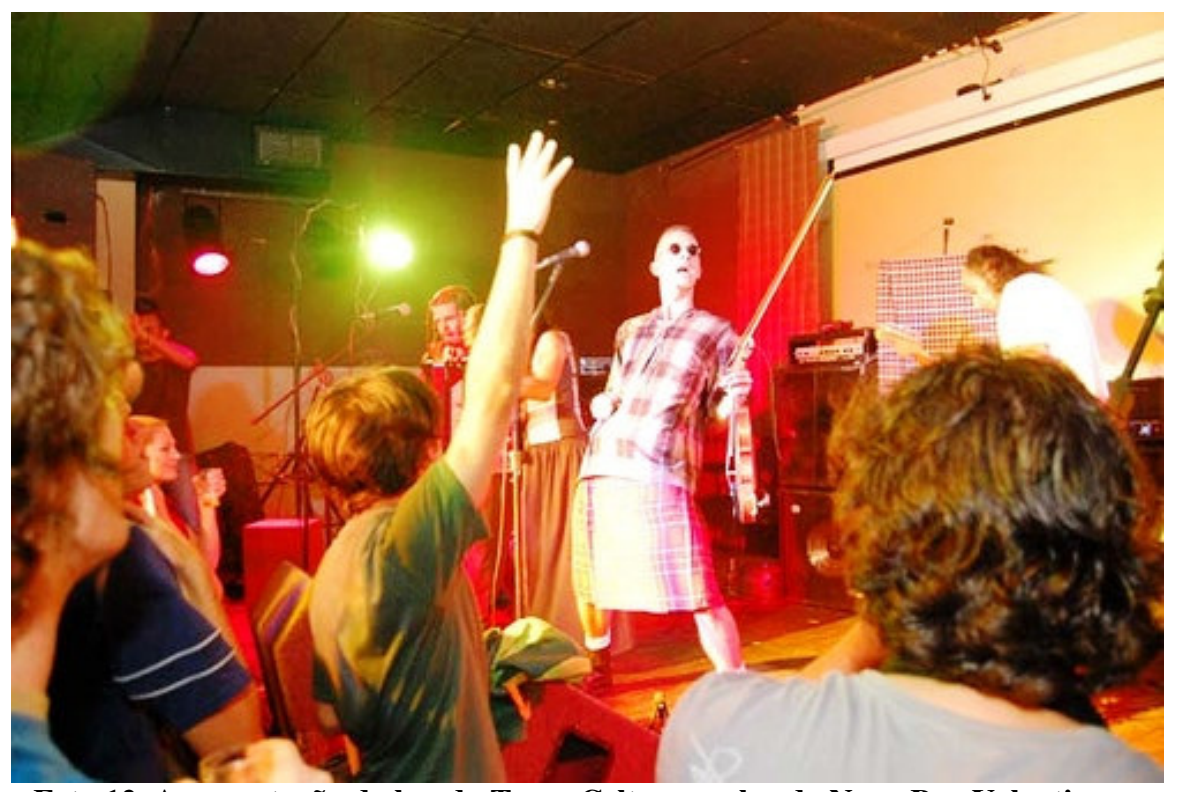

Foto 12. Apresentação da banda Terra Celta no palco do Novo Bar Valentino. Fonte: Acervo pessoal do autor. 
Já o palco, com cerca de $1 \mathrm{M}$ de altura e $30 \mathrm{M}^{2}$, equipado com potentes canhões de luz, está posicionado em uma das paredes perpendiculares ao bar, cumprindo funções diferenciadas, dependendo sempre do evento ocorrido. Se a atração for um show musical ou peça de teatro, este serve exclusivamente de suporte aos artistas; já se o evento for uma mostra de cinema - normalmente curtas-metragens -, ali é montado um telão onde são projetados os filmes. Em ambos os casos a circulação pelo palco é restrita ao público. No entanto, se a noite é animada apenas pelos DJs - que variam o repertório do "brega" aos ritmos eletrônicos, dependendo de sua especialidade -, o espaço é preenchido com algumas mesas e o trânsito de freqüentadores é liberado. Nestas ocasiões, se o DJ atrai grande quantidade de usuários para dançar ou se exibir ali em cima, isso indica sua popularidade e a aprovação por parte dos freqüentadores; da mesma forma, o índice de satisfação do público também pode ser medido pelo número de pessoas que, ao longo da madrugada, abandona suas mesas em detrimento da pista de dança. Na lateral do palco, em uma área de acesso restrito, há ainda um banheiro e pequenos camarins destinados apenas aos artistas da noite.

A julgar pelas diferentes funções cumpridas pelo palco, percebe-se que a programação artística do Novo Bar Valentino é tão, ou mais, variada quanto nos tempos em que o bar permaneceu no centro da cidade. Pois, agora os eventos são realizados em todos os dias da semana, exceto às segundas-feiras, quando ocorre a folga dos proprietários e funcionários ${ }^{47}$. Entretanto, apesar da diversidade de eventos, o atual calendário artístico possui certa regularidade: aos domingos, invariavelmente, são realizados shows musicais (de reggae, rock, MPB, blues, jazz, samba, música celta); às terças-feiras ocorrem noites temáticas animadas por DJs variados ${ }^{48}$, além da realização mensal da mostra de curtas-metragens promovida pela ONG "KINOARTE"; já às quartas-feiras acontecem shows musicais e mensalmente são encenadas peças do projeto "Quarta Tosca", promovido pela Escola Municipal de Teatro; as quintas-feiras dividemse entre os shows e algumas das noites temáticas; enquanto, finalmente, as sextas-feiras e os sábados são destinados mais uma vez aos shows e/ou aos DJs residentes (DJ João

\footnotetext{
${ }^{47}$ Além de servir de suporte a uma programação artística variada, o palco do Novo Bar Valentino também é bastante concorrido. Pois, como relatou um informante-chave, que ocupava um posto superior aos garçons, mas inferior à gerência, dificilmente um artista consegue se apresentar ali se o evento não for marcado com pelo menos quatro meses de antecedência.

${ }^{48}$ Dentre as noites temáticas realizadas atualmente, destacam-se a "Terça Tilt" (rock alternativo); a "Raw Power" (punk rock e glam rock); a "Novidadisco" (novas tendências musicais); a "Groove and Roll" (black music, soul e rock retrô); a "Valentino Eletrônico" (música eletrônica); e a "Ata-me" (ritmos latinos).
} 
Durval e DJ Suzuki, dentre os que se apresentam com mais freqüência), que podem ser tanto o foco principal da noite como, por vezes, também se apresentam apenas após as bandas.

\begin{tabular}{|c|c|c|c|c|c|}
\hline Domingo & Terça & Quarta & Quinta & Sexta & Sábado \\
\hline $\begin{array}{c}\text { Shows } \\
\text { Variados }\end{array}$ & $\begin{array}{c}\text { DJs } \\
\text { (noites } \\
\text { temáticas) } \\
\text { ou Mostra } \\
\text { de Curtas- } \\
\text { Metragens } \\
\text { (Mensal) }\end{array}$ & $\begin{array}{c}\text { Shows } \\
\text { Variados } \\
\text { ou } \\
\text { Teatro } \\
\text { (Mensal) }\end{array}$ & $\begin{array}{c}\text { DJs } \\
\text { (noites } \\
\text { temáticas) } \\
\text { e/ou } \\
\text { Shows } \\
\text { Variados }\end{array}$ & $\begin{array}{c}\text { DJs } \\
\text { (residentes) } \\
\text { e/ou Shows } \\
\text { Variados }\end{array}$ & $\begin{array}{c}\text { DJs } \\
\text { (residentes) } \\
\text { e/ou Shows } \\
\text { Variados }\end{array}$ \\
\hline $\begin{array}{c}07 \mathrm{R} \$ \mathrm{a} \\
10 \mathrm{R} \$\end{array}$ & $\begin{array}{l}\text { 03R\$ ou } \\
\text { Gratuito }\end{array}$ & $\begin{array}{c}07 R \$ a \\
10 R \$\end{array}$ & $\begin{array}{c}\text { 03R\$ ou } \\
07 \text { a } 10 R \$\end{array}$ & $\begin{array}{c}\text { 03R } \$ \text { ou } 07 \\
\text { a 10R\$ }\end{array}$ & $\begin{array}{c}\text { 03R } \$ \text { ou } 07 \\
\text { a 10R\$ }\end{array}$ \\
\hline
\end{tabular}

Tabela 6. Calendário do Novo Bar Valentino.

A regularidade apresentada no calendário artístico, quando associada às preferências - sobretudo as musicais - de determinados grupos de freqüentadores e ao valor do couvert, acaba por segmentar o público do Novo Bar Valentino em certas noites e horários. Contudo, como ocorria na época em que o bar se manteve no centro da cidade, é muito comum que a boate comporte um público bastante homogêneo durante a realização dos eventos, mas que o ambiente se torne cada vez mais diversificado no decorrer das madrugadas. Pois, aqueles usuários mais heterogêneos, que não se interessam por determinadas apresentações artísticas, normalmente aguardam seu término na casinha, quando os DJs entram em cena e o "Clube Valentino" tem seu acesso liberado. Então, ainda que o público possa se segmentar em algumas ocasiões, a diversidade de seus usuários ainda é uma das características mais marcantes do Bar Valentino ${ }^{49}$.

\footnotetext{
${ }^{49} \mathrm{Um}$ apreciador de MPB, por exemplo, dificilmente encontraria freqüentadores assíduos das noites temáticas "Raw Power" ou "Valentino Eletrônico" durante um "Tributo à Elis Regina" realizado na boate; no entanto, existe a possibilidade de ambos compartilharem o mesmo espaço após o show ou durante uma mostra de curtas-metragens, realizada às terças-feiras, com entrada gratuita.
} 
Porém, se, em meio à heterogeneidade de seus freqüentadores, anteriormente o bar fora apropriado majoritariamente por pessoas ligadas ao mundo artístico, por setores mais "intelectualizados" da população - como políticos, jornalistas e estudantes, sobretudo os da Universidade Estadual de Londrina -, e, um pouco mais recentemente, pelas "funções" de "manos", não seria exagerado afirmar que, em determinadas noites, o espaço seja atualmente freqüentado predominantemente por outro grupo: o das "patricinhas" e "playboys". É possível especular que estes usuários, adeptos de outros espaços outrora considerados opostos ao Bar Valentino, tenham sido atraídos pela relativa mudança de conceito sofrida pelo bar, que, em alguns aspectos, agora se assemelha muito a uma convencional boate - com estacionamento privado e serviço de manobrista; filas extensas; infra-estrutura de som e iluminação; pista de dança onde, em certas ocasiões, tocam os principais hits do momento; e sistema de consumo informatizado. Nos trechos a seguir, retirados de entrevistas realizadas com antigos freqüentadores, em ambos o casos os novos adeptos do Bar Valentino são caracterizados por estes usuários como o "pessoal das baladas", ou seja, das boates:

[...] A impressão que me causa é que a moçadinha, de 20, 22 [anos], estudante de faculdade particular, com mais poder aquisitivo vem ao Valentino como se fosse ir pra balada mesmo, pra dançar. Acho que é um pessoal que vem mais das boates mesmo. Do Empório, da Joy, da Vega. Agora também vem o pessoal da balada. Que vem pra ir na parte dos shows ali, pra curtir o som das bandas ou o DJ. Esse público vem agora e não vinha antes. Porque antes não tinha essa característica do espaço pra dançar, né? (Trecho de entrevista, 11.10.2008).

[...] De fim de semana agora eu vou raramente. Mas no antigo eu ia todo dia, todo fim de semana. Mas agora eu não vou mais ao Valentino de fim de semana. Eu acho a música ruim, é super lotado. O público também mudou muito. Eu corro o risco de ser meio preconceituosa falando isso, mas o público que vai ao Valentino agora é aquela classe média, que transita entre a média baixa e a média alta, e que consome cultura de massa. Então é um público que não tem muito critério. É aquele pessoal que só tá atrás da balada, que é 'baladeiro'. Que é aquele 'cara' que vai curtir se tiver tocando sertanejo, que vai curtir se tiver tocando pagode e que vai curtir se tiver tocando rock. Tipo pessoal de boate, sem muito critério. Eu tenho vários amigos que discotecam na 'Terça Tilt' [rock alternativo], por exemplo, e que me contam que as pessoas vão lá e falam: 'Põe alguma música mais conhecida aí'. Então as pessoas querem ouvir a música da parada das rádios. Já no antigo Valentino, as pessoas que 
iam lá durante a semana, iam pra curtir a música que tava tocando. Pra curtir o clima do bar. (Trecho de entrevista, 07.05.2007).

Conforme os depoimentos expostos acima, os novos adeptos do Bar Valentino parecem distanciar-se da maioria dos freqüentadores mais antigos por pelo menos dois fatores: pela opção por outras casas noturnas consideradas "caras" e "elitizadas", como as citadas "Joy", "Vega" e "Empório Guimarães", e por sua preferência musical, pois, na opinião dos usuários mais antigos, se tratam de apreciadores de música "comercial". No trecho a seguir, extraído do site de relacionamentos "orkut.com", em uma discussão realizada entre habitués do espaço desde os tempos do centro, esta impressão não apenas se confirma como ainda é acrescentado outro elemento para caracterizar os novos adeptos do bar: sua vestimenta, quase sempre composta por roupas de grife. Em um caso este elemento é denotado pela reprovação ao uso de scarpins e "botas de rave" por parte de uma garota, e em dois outros ele surge pela oposição ao uso de chinelos pelos garotos:

\section{Valentino Guimarães: ${ }^{50}$}

Acho um absurdo cobrar $10 \mathrm{R} \$$ pra assistir uma banda. Até porque já tinha sido falado que jamais seria cobrado esse preço pra entrar no bar, que agora virou uma boatinha. $O$ pessoal não é mais o mesmo. $\mathrm{O}$ Valentino virou 'popzinho'. As patys e os boys vão em peso... Quem vai no Valentino de scarpin e bota de rave??? Um lixo!

\section{Concordo com a garota do tópico:}

Gente, como não vamos rotular patys e boys? Rotulo mesmo! Dominaram a cidade toda com música pobre e estética intacta! E no único lugar que eu poderia ir de chinelão sem me acharem um pobre agora também foi lapidado... Horrível! Valentino é só um nome agora. O ideal está morto. MORTO!

\section{Hipocrisia!}

Agora vem gente no tópico dizer: 'Os incomodados que se mudem!'. Ah, por favor! 'Não rotulem!'. Por favor também! Você passa na frente daquele lixo daquele Pátio [San Miguel] e só falta as pessoas ligarem pra polícia. Agora vocês vêm falar em discriminação? Quem manteve o Valentino aberto até hoje NÃO foi esse povo que tá indo. Esse pessoal que tá indo agora, aposto que não tinha nem coragem de entrar no antigo Valentino, e, aposto, que quando alguém chamava pra ir, ainda devia tirar uma na cara do 'Valeco'. Só uma observação: esses dias eu tava lá na frente e dois 'boys', nada contra, porém dois 'boys' ficaram ligando pra um cara lá dentro, pra chamar ele pra ir

\footnotetext{
${ }^{50}$ Em referência à boate Empório Guimarães, considerada por muitos dos antigos freqüentadores do Bar Valentino como a mais elitizada da cidade.
} 
pro Empório [Guimarães]. Meu, sinceridade, mas será que algum freqüentador do antigo 'Valeco' ia pro Empório?

\section{Valentino Guimarães Mesmo!}

Infelizmente o dinheiro e a ganância do ser humano tão falando mais alto. E justo no bar que era o mais underground de Londrina! Sinceramente, eu fui lá duas vezes, e achei ruins as duas vezes! Eu só vi um pessoal bem diferente do que ia no bar antes e até o som mudou. O bom rock deu lugar às músicas pop. Isso é o que mais me decepciona. Cadê o rock que embalava as noites e adentrava até às $6 \mathrm{~h}$ da manhã? Aliás, tinha uma frase que eu sempre dizia quando ia no antigo 'Valenta': 'podem falar o que for, mas o som do Valentino é sempre bom!'. Infelizmente, agora o verbo 'é' virou 'foi'.

\section{É uma pena!}

Já havia ido ao bar depois da mudança e já havia me sentido mal lá dentro. Uma galera estranha, que não era a de costume. Mas ontem eu indignei: meninos NÃO podem mais entrar de chinelo havaiana. Meu amigo foi barrado na porta por estar usando um e eu desacreditei. VALENTINO GUIMARÃES TOTAL!

Apesar de a discussão demarcar a insatisfação de alguns usuários quanto à presença maciça de "patricinhas" e "playboys" no Novo Bar Valentino, assim como seu desagrado em relação a algumas das mudanças ali ocorridas - especialmente em relação aos preços, à seleção musical e à restrição de determinados figurinos -, há também freqüentadores que encararam as transformações sofridas pelo bar de maneira favorável. Este é o caso de muitos dos artistas que, desde a época do centro da cidade, se apresentam ali há mais tempo e com maior regularidade - os chamados "dinossauros". Estes usuários avaliaram positivamente a transferência do Bar Valentino, apesar de se ressentirem um pouco quanto à perda da espontaneidade característica aos eventos que se realizavam na casinha. Nos trechos a seguir, o primeiro entrevistado afirma que atualmente o artista pode "mostrar o trabalho de uma forma melhor", embora ressalte sua vontade de realizar apresentações na casa de madeira, enquanto a segunda diz que agora se sente mais "protegida" quando se apresenta no bar, apesar de considerar a casinha "romanticamente mais gostosa":

Essa mudança de endereço, apesar da gente ter se assustado um pouco no começo, né? 'Nossa, vai mudar! E agora?'. Mas foi tudo tão bem feito, tão organizado, que acabou sendo ótimo pro bar. Agora as coisas tão voltando a acontecer lá. Eu acho que a gente ganhou em segurança e ganhou em acomodação também, né? A casinha, que é a grande relíquia tá lá, do mesmo jeito. E isso foi um trabalho fantástico. Mas também foi muito legal que tenha ampliado o espaço. Porque a gente 
tem um palco melhor. Mais condições de por luz, mais pessoas assistindo. Tem uma estrutura melhor agora. $\mathrm{O}$ músico tem mais espaço, tem um som melhor. Dá pra mostrar o trabalho de uma forma melhor. Então, como espaço foi fantástico. Já deu pra ver que dá pra acontecer as coisas lá. $\mathrm{E}$ tem acontecido de uma forma bacana. Mas eu quero fazer uma coisa pra casinha nesse novo espaço. Que é como as coisas aconteciam antigamente. Pra eu poder sentir se houve uma diferença realmente. (Trecho de entrevista, 23.05.2007).

Num primeiro momento foi estranho entrar naquela 'caixa' [referindose ao ambiente da boate]. Mas agora eu já tô familiarizada. Já fiz um monte de show lá. Mas espetáculo mesmo, o primeiro foi ontem. E foi ótimo. Ontem foi bem diferente do antigo. Tudo bem, era bar também. Aquele ambiente de bar. Mas eu me senti muito mais protegida. Ali já tem um cartão, uma informatização, e, consequentemente, uma formalização. Então você já se sente mais protegida. Com certeza agora melhorou, no sentido de que tem mais infra-estrutura. Por exemplo, pra gente fazer aquele espetáculo que a gente fez ontem, que usava o telão e acomodou bastante gente, isso seria impossível lá na casinha. Assim, romanticamente a casinha poderia até ser mais gostosa de fazer aquele espetáculo, mas não teria toda aquela 'infra'. (Trecho de entrevista, 23.05.2007).

A casinha de madeira, ambiente preferido pelos freqüentadores mais antigos, está localizada à esquerda do hall de entrada, e, ainda que não se meçam esforços para manter a neutralidade, o distanciamento e a objetividade do olhar - requisitos necessários à prática etnográfica -, inicialmente, é impossível não se espantar mediante a fidelidade com que o espaço fora reproduzido em seu novo contexto. A intensidade da iluminação, os quadros nas paredes, a disposição das mesas, a vitrine que expõe obras de arte, os desníveis, as janelas, a parede inclinada, o palco, o corredor mais reservado, e a varanda permanecem surpreendentemente da mesma forma em que estiveram nos últimos anos em que o Bar Valentino se manteve na região central. Entretanto, em decorrência da transferência de endereço, algumas modificações foram necessárias para que a velha casinha se adequasse ao projeto do novo bar.

Primeiramente, ao invés de se adentrar ao ambiente por aquela que anteriormente fora sua única, e estreita, porta - na fachada, logo abaixo do letreiro -, agora o acesso se dá por uma de suas paredes laterais, onde se incorporou um grande vão, que resolve as filas e congestionamentos de outrora. Por conta deste novo acesso, vindo do hall, o balcão, que anteriormente ocupava toda a extensão da parede citada, foi recuado, retomando, assim, a mesma disposição que possuía até as reformas de 1998. Além disso, a casinha não possui mais banheiros, pois, agora os freqüentadores que 
optam pela permanência neste ambiente devem usar os sanitários do hall. $\mathrm{Na}$ área externa, agora mais extensa, os muros baixos foram substituídos por alambrados, que a separam do estacionamento, e os jardins sofreram uma reformulação através de técnicas de paisagismo. Dada a perda de comunicação desta área com a rua, as varandas, de onde anteriormente se via todos que chegavam ou deixavam o bar, já não é tão concorrida: pois dali pouco se vê quem entra ou sai da boate - normalmente para "tomar um ar" ou dar uma espiada rápida no interior da casinha.

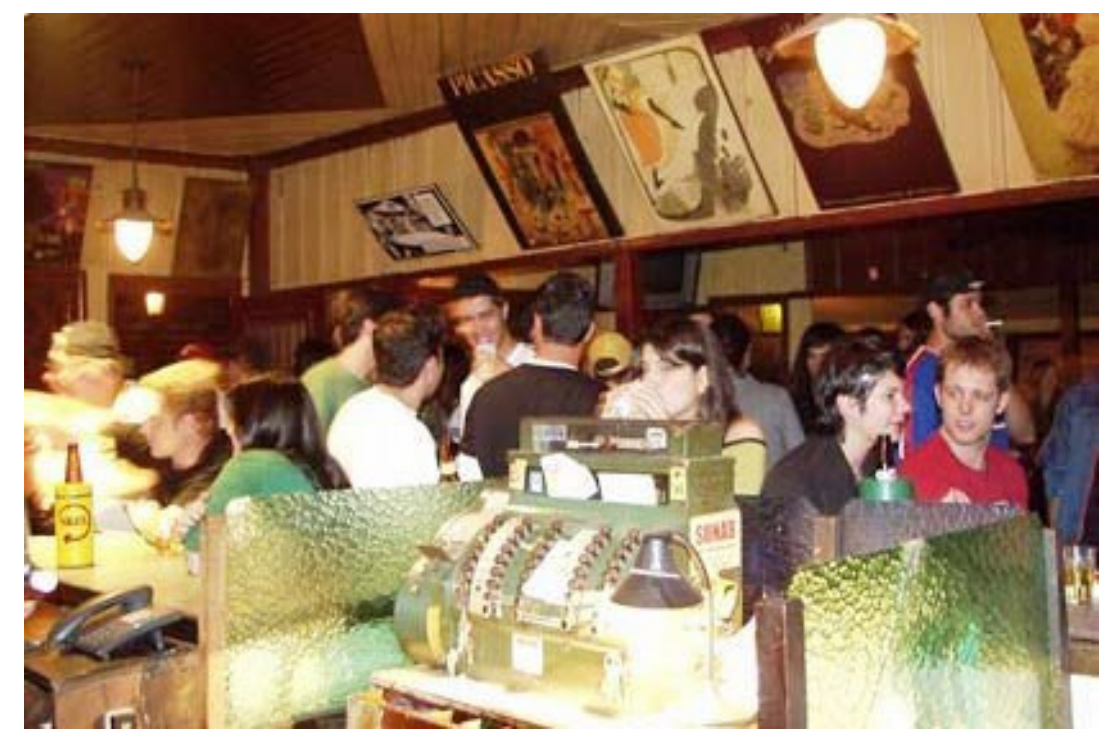

Foto 13. Interior do antigo Bar Valentino visto da área interna ao balcão (2005). Fonte: Acervo pessoal do autor.

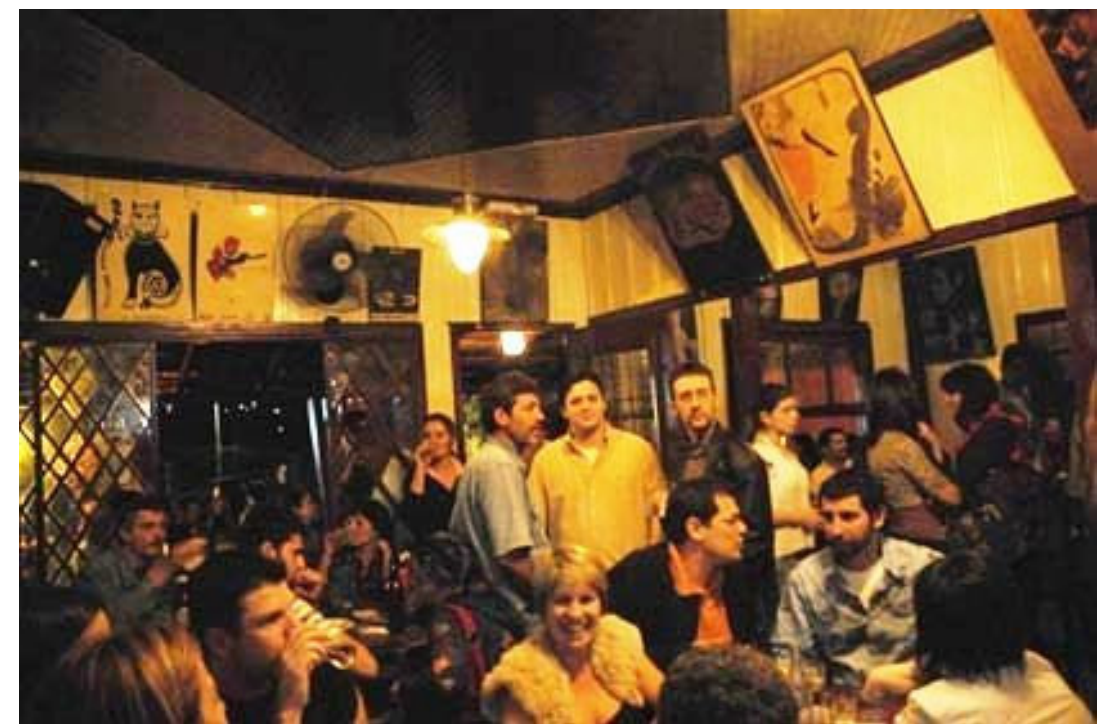

Foto 14. Interior da casinha no Novo Bar Valentino vista da área interna ao balcão (2007). Fonte: Acervo pessoal do autor. 
Mesmo nos dias de maior movimento, quando o trânsito entre os dois ambientes que compõem o Novo Bar Valentino é mais intenso, torna-se perceptível o contraste entre a casinha e a boate. Enquanto a última é um local planejado para a "balada", onde os usuários dançam e paqueram embalados pelas bandas ou DJs que tocam os hits do momento, a primeira é o espaço da "boemia", das mesas e da conversa no balcão, onde se degusta a tradicional macarronada ao som do rock, do blues e do jazz. Não apenas por esta cisão entre um ambiente mais adequado ao pessoal das "baladas" e outro mais propício à "boemia", como também pelos investimentos realizados em segurança e pela reprodução bastante fiel da casinha, muitos dos "dinossauros" que haviam deixado de freqüentar o Bar Valentino nos últimos anos retornaram ao espaço após sua transferência. Pois, a maior parte destes usuários mais antigos considera que, além de o artista contar atualmente com mais infra-estrutura para suas apresentações na boate, a mudança de endereço também proporcionou uma "volta no tempo" na qual o "velho clima" da casinha fora retomado. Como se observa nos depoimentos a seguir, extraídos de entrevistas realizadas com dois dos chamados "dinossauros":

[...] Aquela casinha, sem dúvida, é o Valentino. Ali é o Valentino. Eé muito louco isso, porque o tempo passa, mas as coisas ficam. Então, quando você tá ali, você pode voltar no tempo, né? Eu falo isso pra você tranquilamente, porque às vezes eu tô lá, até meio bêbado, eu vou ali, chego no balcão e falo: 'Gente, que engraçado. Eu tô no Valentino de novo. Tô no Valentino que está num lugar diferente'. $\mathrm{E}$ tem até uma coisa engraçada. Porque quando o Valentino mudou, e eu até ajudei o Chammé a recolocar os quadros lá, a gente teve a preocupação de manter, principalmente os quadros marcantes, exatamente onde eles estavam. E nos primeiros dias, eu ficava ali no balcão do bar, e quando eu ia no banheiro, eu ia naquele corredor. Aí eu me corrigia e ia no lugar certo. Então, é incrível, porque com essa preservação da memória, muitas pessoas voltaram a freqüentar o Valentino depois da mudança. Porque, além disso, tem a questão da segurança. Tem uma questão muito mais cômoda pra quem tem carro. Então, têm muitas pessoas que voltaram a freqüentar o Valentino. E voltaram sabe por quê? Porque a casa ainda está lá. Porque se não tivesse elas iam procurar outro lugar. (Trecho de entrevista, 31/01/2008).

[...] A casinha agora, eu acho que ela tomou ares mais sérios. Mais culturais. Parece que ela voltou muito ao Valentino que eu conheci pela primeira vez. Porque de um tempo pra cá, ali na [Avenida] Bandeirantes, a casinha tava perdendo um pouco da tônica cultural até pelo comportamento das pessoas que freqüentavam. E agora, aquelas pessoas que querem ir pra 'balada' mesmo, elas vão se 
divertir ali na boate. Lá é uma zona mesmo. Mas a casinha passou a recuperar o clima de antes. Sabe? Que é aquele clima onde você se sente bem, onde é tudo de bom gosto. Desde a disposição das coisas, mesmo com aquela aparência de velho, de coisa antiga, até a música que toca. Porque ali na [Avenida] Bandeirantes, chegou um tempo em que você nem tinha mais possibilidade de comer. E o cardápio deles é maravilhoso. A música, muitas vezes, também já não era mais aquela que você queria ouvir no Valentino. E agora isso voltou. Porque a música que toca na boate é diferente da música que toca lá na casinha, né? Então eu acho que agora você pode voltar lá, sentar, olhar todos aqueles quadros com calma, saborear a comida com calma, apreciar a boa música. E é isso tudo que faz ter o velho clima de volta. É lógico, antigamente chegava um momento da noite em que a coisa enlouquecia. Mas você tinha muito disso, de ir lá apreciar o lugar. Antes era um lugar mais tranquiilo. As pessoas de 'balada' mesmo, muitas vezes tinham até receio de ir ao Valentino. (Trecho de entrevista, 23.05.2007).

Desta forma, a partir dos dados etnográficos apresentados até aqui, torna-se possível classificar os atuais freqüentadores do Bar Valentino em três grupos. Primeiramente, existem os novos adeptos, ou as "patricinhas" e "playboys", que não freqüentavam o bar enquanto este se manteve no centro da cidade e que permanecem predominantemente no ambiente da boate, onde ocorrem as "baladas". Em segundo lugar, há aqueles usuários que proponho chamar de "intermediários", que, embora não tenham vivenciado os primeiros anos do Bar Valentino, já o freqüentavam há algum tempo quando de sua transferência de endereço; estes freqüientadores são tendencialmente contrários às mudanças incorporadas ao espaço e oscilam entre a preferência pela boate, quando ocorrem eventos que lhe agradem, ou pela casinha. Finalmente, existem os "dinossauros" - normalmente pessoas ligadas ao mundo artístico e que freqüentam o espaço há cerca de vinte anos -, que, por sua vez, se posicionam tendencialmente favoráveis às últimas transformações sofridas pelo Bar Valentino e têm sua preferência pelo ambiente da casinha, pois só vão à boate em alguns poucos eventos.

No que se refere aos dois últimos grupos citados, suas opiniões, contrárias ou favoráveis às últimas transformações ocorridas no Bar Valentino, parecem denotar, no plano da sociabilidade, certos aspectos do crescimento da cidade e de seu suposto processo de metropolização. Em algumas das entrevistas realizadas com os freqüentadores "intermediários" percebe-se, por exemplo, que sua insatisfação pode ser atribuída à "impessoalidade" que, em suas opiniões, atualmente caracteriza as relações 
sociais estabelecidas no bar. Nos trechos a seguir, a relação entre a "impessoalidade" e a mudança nas concepções formuladas acerca do Bar Valentino fica clara quando, no primeiro caso, a burocracia e a rigidez das normas ali adotadas parecem contrapor-se a certo improviso presente no contexto anterior, levando o entrevistado a qualificar o bar como um lugar "careta" onde foi tratado como "robozinho"; o mesmo ocorre no segundo caso, quando a entrevistada afirma que "agora não tem mais a mesma relação" com o espaço, pois se antes havia a sensação de chegar a um lugar que "era seu", agora ela é "só mais uma ali":

[...] Outro dia eu fui lá [no Novo Bar Valentino] com uns amigos pra ver um show e eu juro que nunca fui tão maltratado assim. Aqueles seguranças são muito estúpidos e autoritários e tudo ali ficou muito burocrático. Agora tem cartão pra estacionar, fila pra entrar e pra pegar outro cartão lá dentro. [...] O ar ali na banda tava irrespirável de fumaça de cigarro, aí eu fui sair pra respirar um pouco enquanto o show não começava e eu fui proibido pelos seguranças. Aí eu fiquei um pouco ali entre a porta de entrada e a de saída e eles me arrancaram dali. Nossa, eu achei isso um disparate! Lá dentro, meu amigo foi enrolar um cigarro e os seguranças enquadraram ele, achando que era um 'baseado'. Quando ele foi enrolar o segundo, o segurança simplesmente arrancou o cigarro da mão dele e disse que não podia fazer aquilo ali e 'estamos conversados'. [...] Na hora de ir embora tinha outra fila pra pagar. Aí, quando eu encostei na parede pra esperar a minha vez, outro segurança me agarrou como se eu fosse um robozinho e me colocou de volta na fila. Como se eu não soubesse o meu lugar. Tudo isso é muito 'careta'. Constrangedor pra 'caramba'. (Trecho de entrevista, 15.01.2008).

[...] Agora eu vou ao Valentino com uma freqüência bem menor. Normalmente eu sou motivada por alguma coisa que nunca é a ida ao bar em si. É sempre por uma discotecagem ou por algum show que vai ter. Então, eu não tenho mais a mesma relação. Porque no antigo, eu tinha a sensação de que eu tava chegando num lugar que era meu. Meus amigos até tiravam sarro de mim, falando que eu era sócia do Valentino. Hoje não. Eu pego uma fila, eu sou só mais uma ali. Eu não conheço mais a maioria dos funcionários que trabalha lá. Ele é um bar que tem muita importância ainda. Mas pra mim não é mais o Valentino. (Trecho de entrevista, 07.05.2007).

Como apontam diversas etnografias realizadas no contexto da cidade de São Paulo, uma das características mais marcantes das metrópoles contemporâneas está associada à possibilidade de trânsito entre o "padrão da aldeia" (MAGNANI, 2000) marcado pelas relações sociais "comunitárias", com a afetividade e a proximidade que 
lhe são próprias - e àquelas relações normalmente atribuídas ao estilo de vida nas grandes cidades, com especial ênfase no anonimato e na impessoalidade. Ao contrário da opinião sedimentada no senso comum, de que a metrópole é o lócus por excelência da solidão e das multidões indiferenciadas, o que tais etnografias urbanas demonstram é que o verdadeiro cosmopolitismo da vida metropolitana reside na possibilidade de as experiências cotidianas fundarem-se tanto no âmbito comunitário quanto no societário ${ }^{51}$.

Neste sentido, acredito que o tom impessoal que, para alguns freqüentadores, atualmente caracteriza o Bar Valentino, pode ser interpretado como uma evidência do suposto processo de metropolização de Londrina. Afinal, quando estes usuários afirmam que agora eles se consideram tratados como "robozinhos" em um lugar onde são "só mais um ali e não conhecem mais a maioria dos funcionários", percebem-se certas nuances metropolitanas em oposição ao tempo em que "todos se conheciam". Ainda, como propõe Fantin (2000) no caso das disputas políticas e simbólicas na metropolização de Florianópolis, certamente, o tom nostálgico e insatisfeito destes freqüentadores decorre do próprio processo de transição de uma cidade média para uma metrópole, no qual o cosmopolitismo ainda não "internalizado" em certos setores da população acaba por aflorar resistências às transformações desencadeadas por este processo.

Como um desdobramento desta tendência à "impessoalidade", no caso do Bar Valentino, alguns "indícios de metrópole" também podem ser identificados a partir da incorporação de um sistema de controle associado à segurança, marcado pela despersonalização e com grande poder de homogeneização sobre os freqüentadores. Pois, dada a significativa ampliação e diversificação de seu público, atualmente a vigilância sobre os usuários do bar já não pode mais ser exercida sob aspectos "comunitários", como os contatos face a face mais típicos dos centros urbanos de pequeno porte. Assim, o espaço em questão parece traduzir, em âmbito microscópico, uma contradição característica ao ambiente metropolitano observada por autores como Simmel (1976 [1902]) - para citar uma análise clássica - e Velho (2004), em um contexto mais atual. Ambos afirmam que em decorrência da heterogeneidade de experiências e costumes própria às grandes cidades, o homem metropolitano tende a

\footnotetext{
${ }^{51}$ Esta tese perpassa diversas das etnografias realizadas no âmbito do Núcleo de Antropologia Urbana da Universidade de São Paulo (NAU - USP), que podem ter suas referências encontradas a partir do site www.n-a-u.org.
} 
viver, cada vez mais, sob certos símbolos homogeneizantes. Enquanto o primeiro autor destaca a primazia de uma "cultura objetiva", pecuniária - onde a vida social parece resumir-se a formula "quanto?" -, o segundo dá ênfase em instituições como, por exemplo, a família, que qualifica como "desviante" qualquer indivíduo que fuja as suas normas de maneira mais acentuada ${ }^{52}$.

Este sistema de controle - impessoal, homogeneizante, e associado à segurança - pode ser apreendido quando se considera um conjunto de medidas composto pela restrição da comunicação entre o Novo Bar Valentino e a rua; pelo procedimento de revista, inclusive com detector de metais; assim como pelas funções atribuídas ao cartão de consumação - que não apenas demarca a preferência dos usuários por determinado ambiente, como também registra informações a seu respeito. Assim, sob tais medidas, uma vez adentrado ao bar, não se pode mais recorrer a outros espaços, como era o caso do "Zerão" e da própria calçada do antigo Bar Valentino, para a compra ou o consumo de drogas ilícitas; e caso isso, assim como alguma briga mais violenta, ocorra, os funcionários possuem meios suficientes, através do cartão de consumação, para identificar o autor da ação, retirando-o do ambiente e bloqueando seu nome no cadastro por um período que pode variar de duas semanas à aproximadamente três meses ${ }^{53}$. É importante ressaltar que, se atualmente tais procedimentos são comuns a diversas casas noturnas, no espaço em questão eles surgem em oposição a um contexto onde as relações sociais entre freqüentadores e funcionários pareciam ser mais personalizadas e muitas vezes marcadas pelas barganhas; seja para driblar a segurança no portão, para assistir às apresentações artísticas sem pagar o couvert ou pela possibilidade de se "pendurar" a conta ao final da noite.

Como pressupõem os dados expostos até aqui, enquanto este sistema é visto pelos chamados "dinossauros" como um "mal necessário" para que o bar evitasse a

\footnotetext{
${ }^{52}$ As considerações de ambos os autores acerca do estilo de vida metropolitano vão na contramão do ideário presente no senso comum de que as grandes cidades são ambientes marcados pela liberdade individual desenfreada. Enquanto Simmel defende a idéia de que "[...] o que aparece no estilo de vida metropolitano como uma dissociação, na realidade é apenas uma de suas formas elementares de socialização" (1976: 14), Velho (2004) elabora o conceito de "campo de possibilidades". Este conceito refere-se às alternativas e possibilidades de sociabilidade construídas em meio às tensões entre os processos sócio-históricos de longa duração, com maior potencial homogeneizante, e a interpretação do mundo simbólico da cultura ao nível das experiências individuais.

${ }^{53}$ Durante o período de pesquisa de campo, soube de pelo menos quatro casos de usuários que tiveram seus nomes bloqueados no cadastro. Em três deles, um relativo à agressão e dois relacionados ao uso de drogas ilícitas nos banheiros, os freqüentadores permaneceram "suspensos" por três meses, sendo que no outro, associado a um usuário que havia bebido demais, "passando dos limites" ao ofender um dos funcionários, a punição foi mais branda, se estendendo por duas semanas.
} 
criminalidade e a violência que se tornaram frequientes no contexto anterior, os "intermediários" normalmente o vêem como uma das causas responsáveis pela perda da espontaneidade que sempre foi característica ao espaço, que para muitos se transformou atualmente em uma "boatinha". Contudo, apesar da questão do controle associado à segurança ter sido citada em todas as entrevistas realizadas durante o período mais recente de pesquisa de campo - entre 2006 e 2008 -, um dos depoimentos recolhidos dentre os usuários "intermediários" é particularmente esclarecedor para a análise aqui proposta. Como se observa no trecho reproduzido a seguir, a freqüentadora afirma que, em sua opinião, o Bar Valentino "acompanhou o movimento da cidade em todos os momentos", podendo ser considerado uma "amostragem precisa da cidade":

[...] Quando eu comecei a freqüentar o Valentino nessa primeira metade da década de 1990, ele era um bar, assim, de intensa manifestação cultural. Então, você tava freqüentando e de repente a moça que tava do teu lado levantava e começava a brigar com uma pessoa que surgia lá do outro lado. Mas a hora que você percebia aquilo, tinha sido tudo armado. Era uma peça de teatro que já tinha sido combinada. Então, tinha um monte de intervenções. Um monte de coisa acontecia lá, e isso era muito intenso. Depois isso foi se amenizando um pouco. Foi ficando mais light. $O$ bar não ficou mais tão cultural como ele era. Ele foi acompanhando o movimento da cidade, que também deixou de ser tão cultural como era. Ele também acompanhou o movimento da cidade porque ela foi ficando com problemas sérios em relação à criminalidade. Então, o Valentino, que era um bar de acolhimento, passou a ser freqüentado por pessoas criminosas. Assim, sempre teve bandido lá. Mas antes era uma coisa mais heterogênea. Depois esses bandidos começaram a dominar lá. Criaram um clima de tensão, de medo, e coisas concretas começaram a acontecer: como aquela história dos tiros. E aí, infelizmente, o bar passou de subversivo pra pervertido. Ele deixou de ser um lugar de liberdade e passou a ser um lugar de pressão, de medo do bandido. Isso foi a gota d'água. [...] Então, eu acho que tudo isso colaborou pra favorecer essa mudança. Tudo empurrou pra essa mudança e pra essas barreiras democráticas que o bar tem hoje. Eu chamo isso de barreiras democráticas. Porque ele é longe, e o pedestre não consegue ir. Você tem um estacionamento cercado, seguranças de terno e gravata. Você tem um computador pra checar seu $R G$. Então, o bar teve que tomar um outro caminho. Pra mim, o Valentino é uma amostragem precisa da cidade. Desde que eu freqüento o Valentino, eu acho que ele acompanhou a cidade em todos os momentos. Teve uma ascensão cultural, depois uma timidez cultural, depois o aumento da criminalidade, e agora ele ficou igual um condomínio fechado. Ele acompanhou toda a movimentação da cidade. (Trecho de entrevista, 07.05.2007). 
Embora as considerações da freqüentadora entrevistada possam soar um tanto exageradas, elas se mostram esclarecedoras quando, no "acompanhamento da movimentação da cidade", é citada a incorporação de certas "barreiras democráticas" que, em sua opinião, transformaram o Bar Valentino numa espécie de "condomínio fechado". Esta sentença - expressa em termos nativos - parece aproximar o espaço ao conceito de "enclave fortificado" proposto por Caldeira (2000) em sua análise etnográfica sobre o crime a segregação na cidade de São Paulo. Nas palavras da autora, tais enclaves constituem-se enquanto:

[...] espaços privatizados, fechados e monitorados, destinados à residência, lazer, trabalho e consumo. Podem ser shopping centers, conjuntos comerciais e empresariais, ou condomínios residenciais. Eles atraem aqueles que temem a heterogeneidade social dos bairros urbanos mais antigos e preferem abandoná-los para os pobres, os "marginais", os sem-teto. Por serem espaços fechados cujo acesso é controlado privadamente, ainda que tenham um uso coletivo e semipúblico, eles transformam profundamente o caráter do espaço público. [...] Privatização, cercamentos, policiamento de fronteiras e técnicas de distanciamento criam um outro tipo de espaço público: fragmentado, articulado em termos de separações rígidas e segurança sofisticada, e no qual a desigualdade é um valor estruturante. [...] O novo meio urbano reforça e valoriza desigualdades e separações e é, portanto, um espaço público não-democrático e não-moderno. (CALDEIRA, 1990: 11 - 12).

Para Caldeira, a incorporação de tais espaços na malha urbana paulistana consolida um processo de segregação que está associado à dinâmica de crescimento da metrópole ao longo de todo o século XX. Pois, se até a década de 1940, São Paulo era concentrada em uma área relativamente pequena, onde a diferenciação de sua população se dava por meio dos tipos de suas moradias, deste período até a década de 1980 a segregação passou a expressar-se por meio das grandes distâncias - com as classes médias e altas ocupando áreas mais centrais e as classes populares residindo nas periferias. Desde então, justapostos a este padrão, surgiram os "enclaves fortificados", que aproximam geograficamente ricos e pobres, separando-os, não mais pela distância, mas por muros e tecnologia de segurança. Se, como defende a autora, este processo ocorrido na metrópole paulistana é uma versão particular de um padrão mais difundido de segregação, não é surpreendente que, ao longo de sua história, Londrina tenha vivenciado uma dinâmica muito semelhante em seu desenvolvimento urbano. 
Afinal, se até a década de 1960 a população londrinense era concentrada majoritariamente no núcleo urbano central, diferenciando-se internamente por ocupar residências em madeira ou casas, palacetes e edifícios em alvenaria e concreto, a partir da década de 1970 este padrão de segregação foi substituído pela expansão exacerbada de áreas periféricas até meados da década de 1990, quando passaram a surgir alguns espaços na cidade que se aproximam bastante aos "enclaves fortificados" observados por Caldeira no contexto paulistano. Tais espaços, ocupados predominantemente pela elite local, encontram-se tendencialmente localizados nas proximidades dos potenciais "subcentros" - como as Avenidas Higienópolis e Madre Leônia Milito - nas regiões sul e sudoeste da malha urbana. Como sintetiza Silva (2003), em sua análise acerca da descentralização em Londrina:

Neste momento (1980), a cidade já apresentava um crescimento considerável, acima de 300.000 habitantes, porém não havia a constituição de outras áreas centrais, o que levou à diferenciação na própria área central de acordo com a valorização dos terrenos, que coincidia com a proximidade do calçadão ou Avenida Higienópolis alta valorização - ou proximidade da rodoviária - baixa valorização. [...] [Desde então] percebe-se que o crescimento da cidade de Londrina, assim como a mudança na lógica da produção do espaço urbano e os interesses que a engendram provocam um processo de fragmentação do espaço urbano, decorrente da emergência de áreas que podem ser diferenciadas claramente pelo padrão de rendimento. Tal fragmentação torna-se evidente com a cristalização e fortificação dos enclaves, que criam homogeneidades internas às áreas e, consequentemente, heterogeneidades entre as mesmas. $\mathrm{O}$ processo de redefinição da centralidade [tem sido particularmente evidente] na porção sudoeste do tecido urbano da cidade de Londrina, área que aprofunda uma especialidade de caráter social destinada às camadas mais abastadas, em área da Antiga Fazenda Palhano, principalmente sob o impacto da construção do Catuaí Shopping Center, em 1990. (SILVA, 2003: $02-03$ ).

Desta forma, sobrepondo as análises de Caldeira (1990) aos dados teóricos acerca da história urbana de Londrina - apresentados no primeiro capítulo e sintetizados por Silva (2003) no trecho acima -, percebe-se que, em suas devidas proporções, tanto no contexto paulistano, como no londrinense, o surgimento destes "enclaves" está associado à dinâmica de crescimento das respectivas cidades. Sob um recorte mais específico, quando consideramos uma das possíveis concepções nativas sobre o Bar Valentino, na qual este é comparado a um "condomínio fechado", com diversas 
"barreiras democráticas", observa-se que, em âmbito local, este espaço pode ser considerado como exemplar de uma tendência bastante recente no crescimento de algumas cidades de médio e grande porte: a proliferação de espaços privatizados, fechados e monitorados para residência, consumo, lazer e trabalho, e que têm sua existência justificada pelo medo do crime violento (CALDEIRA, 1990). No caso em questão, tal justificativa pode ser observada em outro trecho da entrevista concedida por Waldomiro Chammé ao Jornal de Londrina - por meio da qual a transferência do Bar Valentino tornou-se pública -, quando, observa-se, de fato, uma associação consciente entre o sistema de controle informatizado que seria incorporado ao novo espaço e a necessidade de proporcionar maior sensação de segurança aos freqüentadores:

[...] No Novo endereço vai ficar melhor. Vamos proteger quem está lá dentro, e sem fazer seleção por poder aquisitivo. Muita gente sugere que eu cobre $\mathrm{R} \$ 10$ de entrada para 'selecionar' o ambiente. Mas tenho certeza que muita gente deixaria de ir. São pessoas que não tem $\mathrm{R} \$ 10$, mas que tem tudo a ver com o bar - estudantes, principalmente ${ }^{54}$. [...] Quando a pessoa chegar ao Valentino, vai receber um comando. Todo mundo vai ter que passar pelos seguranças, para se identificar, na entrada e na saída do bar. A partir da semana que vem, quando o site entrar no ar, as pessoas poderão se cadastrar gratuitamente, porque o bar será informatizado. Se a gente pensar no Valentino de 20 anos atrás, o bar do último cliente, isso pode parecer estranho. Mas os tempos mudaram bastante. $O$ bar não pode ser exatamente igual ao que era antes. (BRIGUET, 2006: 10).

Em seu depoimento, o proprietário afirma, ainda, que "o bar não pode ser exatamente igual ao que era antes", de forma que tal sistema de controle informatizado é uma conseqüência dos "tempos", que "mudaram bastante" nos últimos 20 anos. Creio que esta afirmação é significativa, na medida em que, novamente, o argumento desenvolvido até aqui se expressa na fala nativa. Afinal, a implantação deste sistema de controle associado à segurança parece consolidar, no plano do lazer, uma tendência à incorporação de certos hábitos e ressalvas decorrentes dos "perigos da cidade grande", que em Londrina tem sido sentida desde o início da década de 1990, quando a cidade passou a se descentralizar mais efetivamente. Ou seja, se estes hábitos e ressalvas já se

\footnotetext{
${ }^{54}$ Note-se que, apesar das palavras do proprietário, nas noites em que são realizados eventos culturais o couvert artístico oscila entre 07 e $10 \mathrm{R} \$$. A esta taxa ainda é somada o valor de $3 \mathrm{R} \$$, caso o usuário pague pelo estacionamento, ou a quantia de $3,80 \mathrm{R} \$$ contando a passagem de ida e de volta para aqueles que dependem do transporte público. Além disso, a cerveja, bebida mais consumida pelos freqüentadores, custa 3,80R \$ em média - valor considerado alto para o padrão dos bares da cidade.
} 
esboçavam entre freqüentadores e funcionários do Bar Valentino em seus últimos anos na região central, eles foram reforçados e aperfeiçoados, aproximando-o de um "enclave fortificado", no mesmo momento em que o bar acompanhou a lógica e o sentido de descentralização da cidade, transferindo-se para uma área de grande valorização, que tem se transformado em um reduto residencial e comercial da elite londrinense.

Assim, os dados etnográficos expostos nesta seção demonstram que, em seu processo de transferência, o Bar Valentino parece indicar algumas tendências da suposta metropolização de Londrina. Além da própria necessidade de ampliação do bar em uma época em que a cidade já não cabe mais em seu núcleo central, tais tendências também podem ser observadas na incorporação de certas relações mais impessoais e despersonalizadas - filas, identificação por meio do cadastro e do cartão de consumação, tratamento indiferenciado pelos seguranças - que, quando associadas a alguns outros fatores, expressam um modelo de controle associado à segurança privada que já se encontra consolidado em algumas das grandes cidades brasileiras. Não deixa de ser notável que estas transformações, ou estes "indícios de metrópole", tenham se tornado mais sintomáticos no Bar Valentino exatamente no momento em que o espaço transferiu-se para uma via e uma área que passam por um processo de valorização, acompanhando o sentido dos investimentos públicos e privados na malha urbana londrinense, expressando, assim, uma tendência ao abandono da região central em detrimento de outras regiões de maior prestígio social.

\subsubsection{A Reconfiguração dos Circuitos}

No segundo capítulo desta dissertação foi defendida a idéia de que enquanto o Bar Valentino permaneceu na região central da cidade, seu espaço caracterizou-se como um ponto de confluência entre alguns circuitos derivados em meio ao circuito de lazer noturno em Londrina. Mediante o mapeamento e a abstração das regularidades intrínsecas a estes circuitos, observou-se que pelas próprias possibilidades de uma cidade média, onde os serviços encontram-se localizados predominantemente em seu núcleo central, os trajetos mais significativos construídos a partir do bar realizavam-se na área do "centro expandido" - ou em suas proximidades -, na escala da "caminhada", 
e com a lógica de seus deslocamentos concluída em uma única noite. Dadas estas considerações, nesta última seção procurarei demonstrar como a transferência do Bar Valentino reconfigurou tais trajetos e circuitos, dotando-os de certas características que expressam uma cidade mais descentralizada, tornando, assim, perceptíveis o sentido e a lógica do crescimento de Londrina no plano físico-espacial.

Como já exposto ao longo deste trabalho, o Bar Valentino tornou-se um dos espaços de articulação no circuito de lazer noturno em Londrina, exercendo funções diferenciadas dependendo do circuito derivado tomado como referência. No caso do “circuito GLBTT", por exemplo, o bar permitia um contato mais íntimo entre seus adeptos, que não lhes era possível em outros espaços, como o "Bar do Jota", o "Mangá" e o "Bar Varanda"; já no que se refere ao "circuito universitário de MPB", o Bar Valentino figurava como uma opção para que diversos estudantes encerrassem a noite em um local próximo as suas "repúblicas", predominantemente localizadas na região central; no "circuito dos "manos", por sua vez, o espaço funcionava como um local onde era possível aguardar em segurança o primeiro ônibus da manhã rumo às diversas "quebradas", muitas vezes longínquas ao centro da cidade; finalmente, no "circuito de artes", era ali onde se realizavam e celebravam os eventos planejados, por exemplo, na Secretaria Municipal de Cultura, na Casa de Cultura da UEL ou nas escadarias do Edifício Centro Comercial. Em todos estes casos, o Bar Valentino tornou-se um aporte fundamental não apenas pela diversidade de seu calendário artístico e pelas referências que lhe foram historicamente atribuídas, mas, sobretudo, por seu horário de funcionamento e por sua localização considerada "privilegiada" na malha urbana.

Desta forma, ainda que o Bar Valentino permaneça atualmente como uma das principais referências para os adeptos destes circuitos, a partir de sua transferência para uma área mais afastada ao centro da cidade, suas funções foram relativamente atenuadas e assumidas por outros equipamentos de lazer - distribuídos entre a região central e o quadrante sul-sudoeste -, que se tornaram novos "espaços-âncora" para a realização destes deslocamentos. Dentre estes espaços, destacam-se o bar "PeopleS" e o "David Club" no "circuito GLBTT" (contato íntimo), a "Estação Café Brasil” no "circuito universitário de MPB" (proximidade às "republicas") ${ }^{55}$; o bar "Pé na Cova" no

\footnotetext{
${ }^{55}$ Apesar de este equipamento estar localizado no quadrante sul-sudoeste da malha urbana, na mesma via onde se afixou o Bar Valentino, a partir das conversas informais realizadas com seus frequientadores percebe-se que ele é considerado como "central", e, portanto, próximo às "repúblicas" estudantis; pois o
} 
"circuito dos "manos" (proteção); assim como a "Vila Cultural Cemitério de Automóveis" e o "Tomate Seco Café Teatro" no "circuito de artes" (realização e celebração de eventos artísticos). Assim, tendo em vista a mudança de conceito sofrida pelo Bar Valentino, assim como sua atual localização na malha urbana, além de algumas características destes novos "espaços-âncora", torna-se notável que estes circuitos derivados tenham se expandido tanto temporal quanto espacialmente.

No que se refere à expansão temporal dos circuitos, a partir de fórmulas como "eu era um frequientador diário do bar", "eu batia cartão no Valentino", "meus amigos falavam que eu era sócia do Bar Valentino”, percebe-se que, se anteriormente muitos usuários freqüentavam o bar quase que diariamente, agora, eles o fazem mais ocasionalmente - cerca de uma ou duas vezes na semana. Afinal, sua transferência para uma área mais afastada ao centro da cidade, bem como a incorporação de taxas obrigatórias e relativamente caras, impede que seus frequientadores tenham a mesma assiduidade de outrora. Em relação ao couvert e as taxas obrigatórias, o mesmo ocorre com todos os demais "espaços-âncora" de seus respectivos circuitos - à exceção do "Bar Pé na Cova" no "circuito dos "manos"” -, impossibilitando que seus adeptos transitem por mais de um ou dois equipamentos em uma única noite. Dados estes fatores, observa-se que, se anteriormente a lógica dos trajetos que invariavelmente confluíam no Bar Valentino era concluída em um período notadamente mais curto, na maioria das vezes em uma única noite, atualmente ela se expressa pela preferência entre equipamentos considerados "secundários", os novos "espaços âncora" e o próprio Bar Valentino em um eixo temporal mais extenso.

No caso do "circuito GLBTT", por exemplo, constata-se que um de seus trajetos mais típicos é agora composto pelo deslocamento "Bar Valentino (terça-feira) $\rightarrow$ Varanda ou Bar do Jota (terça ou quarta-feira) $\rightarrow$ F.R.I.E.N.D.S. ou PeopleS (quinta, sexta ou sábado) $\rightarrow$ Bar Valentino ou David Club (sexta-feira ou sábado)". Neste caso, a lógica dar-se-á: (01) Pela realização de uma noite temática no Bar Valentino ("Valentino Eletrônico" ou "Ata-me"); (02) Pela permanência em "espaços secundários" no meio da semana, onde ocorram apenas flertes e paqueras, mas não seja exigida consumação ou couvert ("Varanda" ou "Bar do Jota"); e, (03) Pela escolha de um "espaço-âncora" no final de semana, que, embora exija taxas ou couvert, possibilite 
contatos mais íntimos entre seus usuários ("Bar Valentino" ou "David Club"). A mesma lógica ocorre quando se considera as reconfigurações estabelecidas no "circuito universitário de MPB", no "circuito de artes" e no "circuito dos "manos"”.

Enquanto o "circuito universitário de MPB" apresenta como um de seus trajetos típicos o deslocamento realizado, por exemplo, entre "Bar do Jota (terça-feira, sem couvert) $\rightarrow$ Brasiliano Bar (quarta-feira, sem couvert) $\rightarrow$ Bar Valentino (quinta-feira, com couvert) $\rightarrow$ Estação Café Brasil (sábado, com couvert)", o "circuito de artes" pode realizar-se a partir do trânsito entre "Concha Acústica (período da tarde, espaço público) $\rightarrow$ Bar do Jota ou Drink's Bar (segunda ou terça-feira, sem couvert) $\rightarrow$ Bar Valentino (quarta-feira, com couvert) $\rightarrow$ Tomate Seco Café Teatro ou Vila Cultural Cemitério de Automóveis (sexta-feira ou sábado, com couvert)". Já o "circuito dos "manos"” apresenta atualmente os mesmos espaços que lhe eram característicos no contexto anterior - à exceção do "Bar Kotovelo's", que encerrou suas atividades. No entanto, agora, seus trajetos, marcados pelo deslocamento "Posto Ecos $\rightarrow$ Bar Pé na Cova" (sem couvert), ou o inverso, incorporam o Bar Valentino (com couvert) apenas em algumas noites; principalmente às sextas-feiras ou aos sábados.

Em todos estes casos, ainda que estes circuitos derivados possam sofrer inúmeras variações em relação aos dias da semana e aos espaços que os compõem, todos eles apresentam a mesma lógica: a escolha de seus adeptos entre "espaços secundários", com ausência de taxas; os novos "espaços-âncora" na região central ou nas zonas sul e sudoeste, marcados pela cobrança de couvert; e o próprio Bar Valentino, a partir de um eixo temporal marcado aproximadamente pela escala da semana.

Já em relação à expansão espacial destes circuitos derivados, percebe-se que, se no contexto anterior os equipamentos localizado fora das adjacências da área do "centro expandido" eram considerados "ocasionais", ou "secundários", no atual contexto há uma tendência à incorporação de "espaços-âncora" no quadrante sul-sudoeste da malha urbana ("Mapa 11”, na página seguinte). Certamente, isso não se deve apenas à inauguração de alguns equipamentos nesta área ("Estação Café Brasil”, "PeopleS”) após a - comercialmente - bem sucedida transferência do Bar Valentino para a região, mas também à maior visibilidade que o bar proporcionou aos espaços ali já existentes quando de sua mudança de endereço (“Tomate Seco Café Teatro”). Neste sentido, a expansão espacial dos circuitos em direção ao quadrante sul-sudoeste, expressa uma tendência equivalente à observada por de Fantin (2000) em sua análise acerca da 
descentralização do carnaval em Florianópolis. Pois, se como afirma a autora, o "jeito metropolitano de festejar" é um "festejar descentralizado", de forma que "[...] nas metrópoles e nas grandes cidades a festa é múltipla, acontece em vários lugares simultaneamente" (2000: 133), o mesmo parece ocorrer com as atuais formas de se usufruir o lazer noturno em Londrina, evidenciando uma maneira metropolitana, ou seja, "descentralizada", de se desfrutar as "baladas". Como expõe o mapa a seguir:

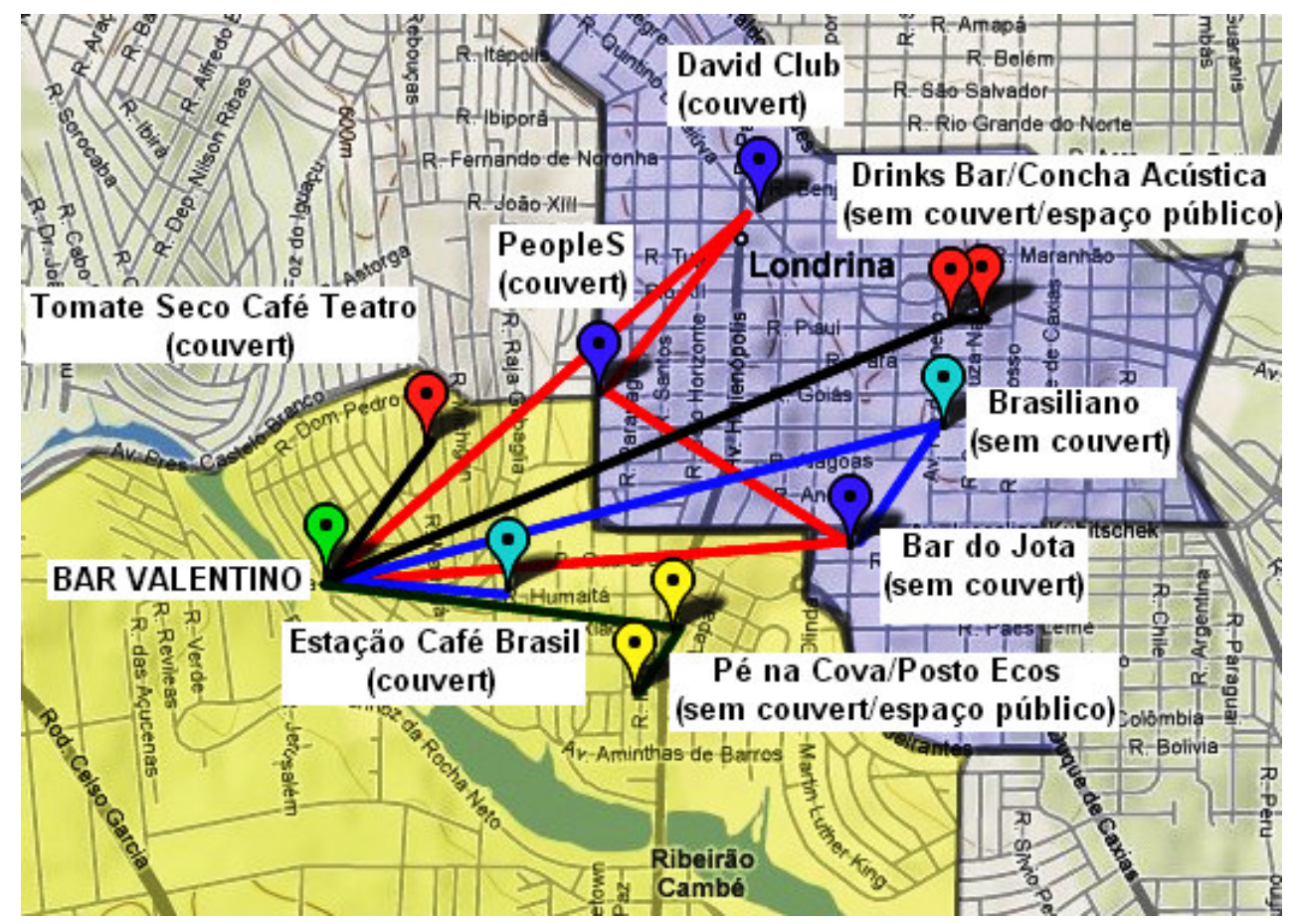

\section{Centro Expandido}

\section{Zona Sul-Sudoeste}

"Trajeto" típico ao "circuito GLBTT"

/ "Trajeto" típico ao "circuito universitário de MPB"

\section{"Trajeto" típico ao "circuito dos 'manos"' no centro de Londrina}

\section{"Trajeto" típico ao "circuito de arte"}

Mapa 11. Sobreposição de trajetos característicos a alguns circuitos de lazer noturno em Londrina (2008)

Fonte: www.google.maps; editado pelo autor. 
A partir desta tendência à descentralização dos circuitos de lazer noturno, se observa, ainda, uma outra alteração ocorrida nos trajetos que os compõem: a realização de deslocamentos na escala do automóvel, e não mais na da "caminhada". Da mesma forma que, como já observado neste capítulo, a grande maioria dos usuários do bar recorre atualmente ao transporte automotivo para a realização de seus trajetos, esta consideração também é válida para alguns dos novos "espaços-âncora" característicos aos circuitos derivados em questão. Afinal, pela atual disposição destes equipamentos na malha urbana percebe-se o relativo aumento da distância física entre as imediações do centro da cidade - área de maior densidade da população - e a região onde tais espaços estão localizados, de forma que alguns trajetos tornam-se inviáveis sob o recurso da "caminhada".

Assim, a reconfiguração dos circuitos derivados realizados sob a referência do Bar Valentino parece trazer à tona, no plano do lazer, alguns aspectos da atual fase de crescimento da cidade. A expansão espacial de seus trajetos, marcada pela incorporação de alguns "espaços-âncora" no quadrante sul-sudoeste, denuncia, por exemplo, a descentralização do município, e, consequentemente, dos circuitos de lazer. Áreas anteriormente consideradas menos atrativas - pela ausência de equipamentos urbanos voltados aos serviços e por sua distância em relação ao núcleo central -, aos poucos, estão se tornando relativamente mais próximas e integradas ao centro; fato que se deve não apenas ao uso mais intensivo do automóvel, como também à maior visibilidade destas áreas por parte da população e dos investidores locais.

A expansão temporal destes deslocamentos, por sua vez, evidencia um leque de escolhas e possibilidades mais característico aos centros urbanos de maior porte, já que, como afirma Magnani (2006), as grandes cidades se caracterizam pela ampliação e multiplicação das possibilidades de uso e desfrute de seus equipamentos urbanos sob uma intensidade impossível em escalas menores. Desta forma, percebe-se que com o surgimento, ou a descoberta, de outros espaços capazes de cumprir as funções outrora concentradas pelo Bar Valentino, os adeptos destes circuitos derivados, agora, possuem uma gama maior de possíveis combinações entre estes equipamentos - "espaçosâncora" ou "secundários"; com ou sem couvert; próximos ou mais distantes ao centro; começo, meio ou final da semana -, que, inclusive, não os permitem arranjá-los em uma única noite. Ou seja, no que se refere aos equipamentos e práticas de lazer noturno, com o crescimento da cidade, sobretudo com indícios de uma nova centralidade, há também 
um incremento da diversidade e das possibilidades de escolha em meio ao fluxo pela malha urbana.

Contudo, a transferência do Bar Valentino implicou ainda em outra transformação nos circuitos de lazer noturno, capaz de evidenciar de maneira mais nítida o atual sentido e a lógica de expansão do município. Esta transformação refere-se à incorporação do bar ao "circuito das 'patricinhas' e 'playboys"”, que, no contexto anterior, era caracterizado pelo fluxo entre espaços que lhe eram considerados opostos. Desta forma, ao contrário de outrora, o Bar Valentino agora é marcado pela complementaridade a equipamentos como os bares "Escritório" e "Pau-Brasil", a "Choperia Fábrica I", as boates "Vega”, "Joy”, “Acústico" e "Empório Guimarães”, e a conveniência "Pátio San Miguel" - todos eles localizados no quadrante sul-sudoeste da malha urbana, à exceção dos dois últimos, como exposto a seguir:

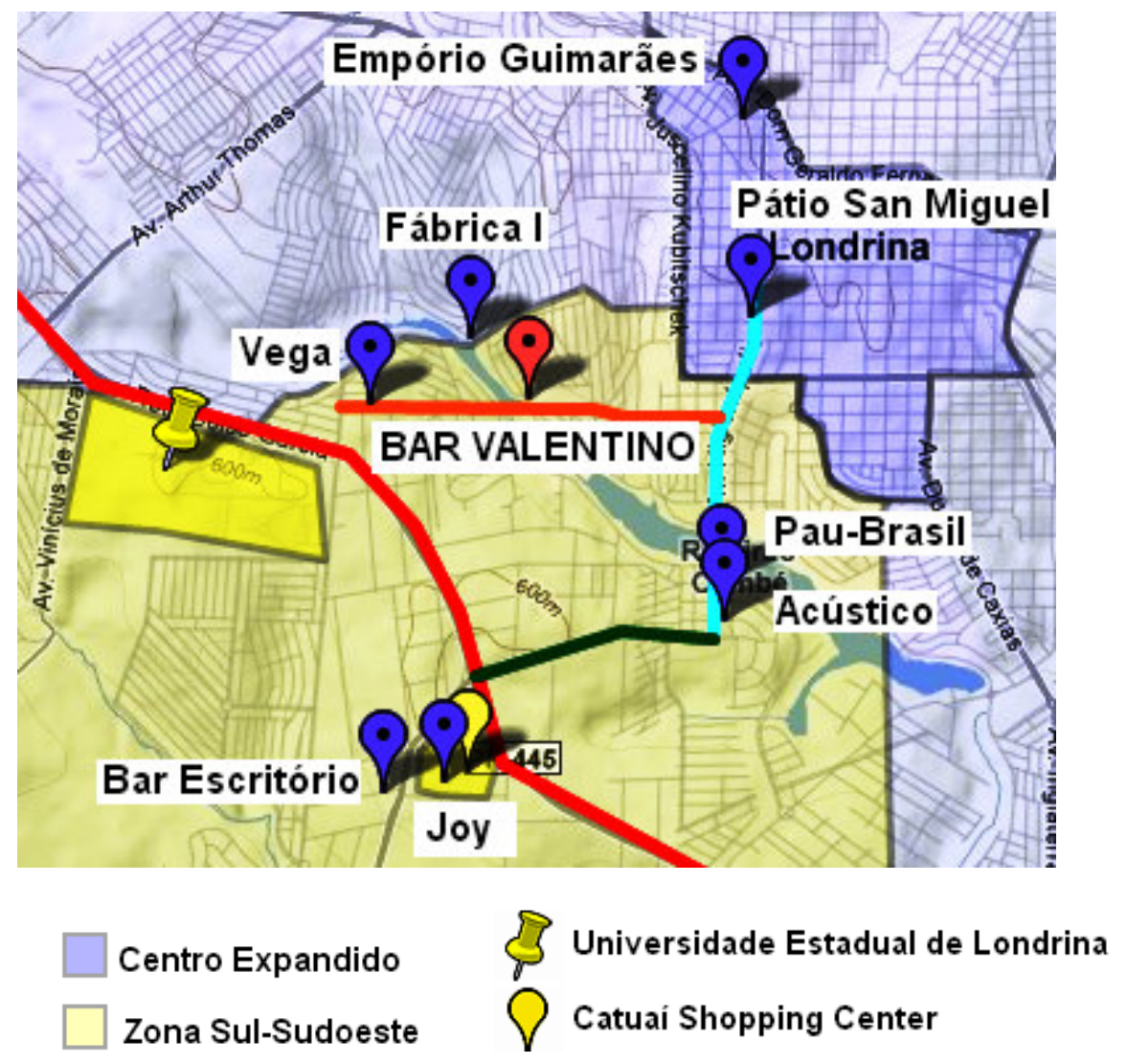

Mapa 12. Espaços característicos ao "circuito das 'patricinhas' e 'playboys"' em Londrina (2008).

Fonte: www.google.maps; editado pelo autor. 
Como nos outros casos citados, a lógica deste circuito também é concluída em um eixo temporal mais extenso, oscilando entre o fluxo por espaços como lojas de conveniência, bares, boates e a citada choperia ao longo da semana - como, por exemplo, no caso do trajeto "lojas de conveniência (terça-feira, sem couvert) $\rightarrow$ PauBrasil ou Choperia Fábrica I (quarta-feira, com ou sem couvert) $\rightarrow$ Bar Valentino (quinta-feira, com couvert) $\rightarrow$ Boate Vega ou Empório Guimarães (sexta-feira ou sábado, com couvert)". Tendo em vista a extensão temporal deste circuito, constata-se que, embora a maior parte de seus equipamentos compartilhe da mesma região da cidade, a relação de complementaridade que estes espaços possuem entre si, e com o Bar Valentino, parece estar mais associada a uma "proximidade estrutural" do que à "proximidade física" propriamente dita.

De maneira geral, conforme a análise clássica de Evans-Pritchard (1999) sobre as concepções de "tempo" e "espaço" entre os Nuer do Sudão Meridional, enquanto o conceito de "distância ecológica" demarca relações espaciais de maneira absoluta, a noção de "distância estrutural" é sempre relativa. Segundo sua análise, esta última categoria explica como, para os Nuer, em certos casos, indivíduos geograficamente mais distantes podem ser considerados muito mais próximos do que aqueles que se encontram espacialmente contíguos. Segundo o autor, isso é possível mediante um sistema de lealdades políticas, etárias e de linhagens, que quando acionado, em caso de conflitos e guerras, por exemplo, acaba por anular qualquer noção física, ou "ecológica", de distância. Então, em a analogia às categorias elaboradas por EvansPritchard, torna-se possível afirmar que, ao transferir-se de endereço e ao sofrer uma mudança de conceito, assemelhando-se muito a uma tradicional boate, o Bar Valentino passou a compartilhar de certas "lealdades", ou de certas características, que o tornaram não apenas física como estruturalmente mais próximo aos equipamentos de lazer freqüentados por "patricinhas" e "playboys".

A analogia ao conceito de "distância estrutural" pode ser mais bem esclarecida quando se considera, por exemplo, que a expressão "Valegay", sob a qual os freqüentadores mais antigos se referiam, tanto carinhosa como pejorativamente, ao espaço, em larga medida, foi substituída atualmente - sobretudo entre os usuários classificados como "intermediários" - pelo termo "Valentino Guimarães". Sob estas considerações, em seu novo contexto o bar parece distanciar-se dos equipamentos mais característicos ao "circuito GLBTT", aproximando-se estruturalmente da boate 
"Empório Guimarães", marcada por uma distância geográfica significativa em relação ao Bar Valentino, mas por uma afinidade bastante regular para com seu espaço ("Mapa 11" e "Mapa 12", acima). Da mesma forma, a atual proximidade estrutural entre o Bar Valentino e o "circuito das "patricinhas' e 'playboys"” também pode ser observada a partir das relações estabelecidas entre o bar o "circuito dos 'manos"”.

Neste caso, como já observado aqui, nos últimos anos em que o espaço permaneceu na região central, o grupo que mais se sobressaía em meio à heterogeneidade de seu público eram os chamados "manos", provenientes de áreas mais periféricas, que, para muitos freqüentadores, haviam "invadido" o Bar Valentino, transformando-o em um local dominado pelo "medo" e pela criminalidade. No entanto, após sua transferência de endereço, embora o bar continue a comportar freqüentadores bastante heterogêneos, inclusive, com a predominância dos chamados "manos" em algumas noites, a representação dominante entre seus usuários "intermediários" se dá em torno de uma "boatinha" elitizada e freqüentada pelos jovens de maior poder aquisitivo. Já quando se considera a opinião dos “dinossauros”, prevalece a impressão de um lugar onde o "bom gosto" fora retomado. Em outras palavras, a partir das representações construídas sobre o Bar Valentino, tem-se claro que após sua transferência de endereço o bar tornou-se simbolicamente mais próximo às elites do que às camadas populares, ainda que ambos compartilhem de seu espaço.

Dadas estas considerações, a maior afinidade e a proximidade física do Bar Valentino aos equipamentos que compõem o "circuito das 'patricinhas' e 'playboys"” evidencia como, a partir de sua transferência para o quadrante sul-sudoeste, o bar sofreu uma mudança de status, deixando de ser um espaço "barra pesada" - que para alguns era freqüentado por "gays", "viadinhos" e "sapatões", e que para quase todos era ocupado por "criminosos", "bandidos" e "marginais" - para transformar-se em um local de "bom gosto" e que figura entre os preferidos pelos jovens provenientes da elite londrinense. Ou seja, ao abandonar o centro da cidade o espaço passou de "estigmatizado" para "socialmente valorizado". Certamente, isso não está associado apenas à sua mudança de conceito ou ao perfil sócio-econômico de seus novos freqüentadores, mas também à sua localização na malha urbana. Afinal, a área onde se fixou o Bar Valentino constitui-se enquanto uma região de grande "prestígio social"; 
fato que pode ser traduzido pelos equipamentos urbanos que, na forma de "enclaves exclusivos", cada vez mais têm sido atraídos para lá ${ }^{56}$.

Então, o processo de transferência do Bar Valentino, com suas respectivas implicações nos circuitos de lazer noturno, parece traduzir, a partir de um caso particular, o movimento que tem sido característico ao crescimento da cidade nas últimas duas décadas. Como foi apontado ao longo desta dissertação, trata-se da tendência à transferência dos equipamentos urbanos de uso mais exclusivo, bem como de grande parte dos investimentos, tanto públicos como privados, da região central área social e financeiramente mais valorizada da malha urbana londrinense até a década de 1990 - para as zonas sul e sudoeste. No caso do Bar Valentino, a reconfiguração dos trajetos e circuitos construídos sob sua referência evidência como o acesso a essa nova centralidade, de fato, é relativo, ou seja, depende sempre do grupo, ou do deslocamento, tomado como parâmetro.

Neste sentido, percebe-se que, apesar da tendência à descentralização dos circuitos de lazer noturno rumo ao setor sul-sudoeste da cidade, aqueles deslocamentos que outrora possuíam uma afinidade mais íntima em relação ao bar, em algum grau, se distanciaram do espaço justamente pelo fato de a região central mostrar-se ainda como um grande referencial. De maneira oposta, o "circuito das 'patricinhas' e 'playboys"” aproximou-se do Bar Valentino, que antes lhe era oposto, exatamente por seu atual distanciamento em relação ao centro da cidade. Esse jogo entre proximidades e distâncias relativas denota, no plano do lazer, a mesma dinâmica constatada em contextos mais macroscópicos, nos quais as áreas de ocupação mais recente são observadas como predominantemente apropriadas pelas elites na mesma medida em que o centro da cidade parece ser "deixado" para as camadas médias e para as classes populares.

Mas, além de apontar o sentido e a lógica socialmente excludente de expansão da cidade no plano físico-espacial, o que a análise etnográfica destes circuitos também demonstra são as novas formas de se usufruir o lazer e as "baladas" em uma "cidade

\footnotetext{
${ }^{56}$ Além das próprias casas noturnas que compõem o "circuito das 'patricinhas' e 'playboys"”, conforme levantamento realizado por Silva (S/d.), dentre estes se destacam: dois campi de universidades particulares, a Faculdade Pitágoras/Metropolitana e a Universidade Norte do Paraná (UNOPAR), com mensalidades que variam de 300,00R\$ à 1.300,00R\$; um hotel de luxo, o "Confot Suites", filial da rede internacional "Choice Hotels International"; cerca de doze loteamentos horizontais de padrão elevado; e o Catuaí Shopping Center, com raio de influência macro-regional, ao qual se deve o início da dinâmica de toda a ocupação do quadrante sul-sudoeste da malha urbana.
} 
grande", que começa a se descentralizar mais efetivamente. Como observado nesta seção, ao mesmo passo em que o leque de opções é ampliado, sobretudo, pela maior probabilidade de combinação entre espaços mais próximos ou mais distantes à região central, a possibilidade de arranjo entre estes diversos equipamentos em uma única noite é mais reduzida. Contudo, essa redução decorre da maior extensão territorial da cidade, bem da própria diversificação das estruturas e equipamentos urbanos; pois, especialmente, pelo incremento da diversidade e pelas novas opções abertas pela atual escala da cidade, os circuitos só podem ser percorridos e concluídos em um eixo temporal mais extenso. Assim, diferentemente do que se dissemina no senso comum e do que propõem muitas análises acadêmicas, o crescimento da cidade não implica necessariamente em sua desestruturação ou ao abandono suas populações à própria sorte. Pelo contrário, como propõe esta etnografia dos circuitos de lazer noturno em Londrina, a mudança de escala vivenciada atualmente pelo município tem sido acompanhada não pela desorganização, mas pela reorganização de sua população a partir das novas possibilidades de fluxos e encontros pela malha urbana. 


\section{CONCLUSÃO}

A idéia que permeou todo este trabalho e que serviu de ponto de partida para seu desenvolvimento foi a de que Londrina vivencia atualmente um momento diferenciado de sua história urbana. Embora a metropolização do município não seja consensual no plano teórico, ainda assim, a mudança de escala experimentada pela cidade nas últimas duas décadas evidencia alguns "indícios de metrópole”, ou, em última análise, esclarece o sentido e as bases gerais sob as quais se dará seu crescimento nos próximos anos.

De maneira geral, conforme os dados teóricos expostos no primeiro capítulo, se até a década de 1960 o crescimento de Londrina era percebido, sobretudo, pelas intensas e sucessivas transformações na paisagem de seu núcleo central, desde então, com o declínio da cafeicultura no Norte do Paraná, o município passou a expandir-se de maneira mais efetiva. Este processo, no qual o sul da malha urbana foi paulatinamente ocupado pelas elites enquanto o norte o foi pelas camadas mais populares, consolidouse na década de 1990 com a construção do Catuaí Shopping Center na zona-sudoeste da cidade, que atraiu para a região grande parte dos investimentos realizados em infraestrutura viária, bem como os serviços, o comércio e os loteamentos residenciais destinados aos setores da população com maior poder aquisitivo. Atualmente, pelo número de empreendimentos que tem atraído, a área localizada entre o núcleo urbano central e as imediações do shopping vem ganhando contornos de uma nova centralidade em Londrina, dotando a cidade de uma das características mais caras às metrópoles contemporâneas no plano físico-espacial, ou seja, a descentralização de sua malha urbana.

As analises já realizadas acerca deste processo, em áreas como História, Sociologia, Geografia, Arquitetura e Urbanismo, notadamente pautadas em variáveis "macro", invariavelmente, apontam para o caráter socialmente desigual que marca a história urbana de Londrina desde o seu surgimento e que parece agravar-se na atual fase de expansão do município. Desta forma, sem negar estas análises, mas, pelo contrário, aproveitando-se das pistas por elas deixadas, a intenção aqui foi estabelecer um diagnóstico pautado em dados mais qualitativos, sob os quais o crescimento da cidade pudesse ser apreendido de um ponto de vista diferenciado, que prioriza mais as

opiniões e seus impactos para aqueles que, de fato, o vivenciam, do que os grandes 
números e as transformações mais evidentes na paisagem urbana londrinense. Para tanto, foi estabelecido o recorte em torno do Bar Valentino, um dos espaços de sociabilidade noturna mais tradicionais de Londrina, que em seu processo de transferência, do centro para o quadrante sul-sudoeste da malha urbana, acompanhou o sentido e a lógica de expansão do município já apontados em outras pesquisas. Mas sob a perspectiva etnográfica aqui adotada, para além do crescimento da cidade no plano físico-espacial, a transferência do bar parece indicar algumas das concepções, resistências e conflitos decorrentes da suposta metropolização de Londrina também no plano da sociabilidade.

Assim, sob este recorte, a estratégia de pesquisa adotada ao longo desta dissertação foi construída em dois eixos distintos, porém complementares. Primeiramente, o foco foi direcionado ao âmbito mais restrito do Bar Valentino, tanto anterior como posteriormente à sua mudança para o quadrante sul-sudoeste da malha urbana. Retomando sua história, inicialmente foi possível observar que o espaço sempre excedeu as "funções comerciais manifestas" normalmente atribuídas aos bares expressa pela venda de bebidas -, que, na opinião popular, muitas vezes os tornam como responsáveis por algumas das mazelas sociais, como a violência e a criminalidade, que atualmente caracterizam as grandes cidades brasileiras. Afinal, o que demonstra a história do Bar Valentino é que, sobretudo em seus primeiros anos de existência, seu espaço fora fundamental para a disseminação de novas tendências estéticas, artísticas, políticas e sexuais entre as camadas mais "intelectualizadas" da cidade. Além disso, por volta de meados da década de 1980, com a ampliação de seu público, o bar transformou-se em importante suporte de sociabilidade para um contingente maior de freqüentadores, tornando-se um dos points mais efervescentes das madrugadas londrinenses. Desde então, por sua "atmosfera artística" e "democrática", o Bar Valentino passou a ser palco para o encontro e a troca de experiências entre diversos grupos urbanos, que viam ali uma possibilidade de exercer mais abertamente seus interesses de uma maneira que, em alguns casos, não lhes era permitida em outras esferas sociais ou em outros equipamentos de lazer.

Em um contexto mais atual, mas ainda anterior à sua transferência de endereço, a análise evidenciou também que, na década de 1990, com o início da "retirada" mais efetiva das elites em direção às áreas de expansão recentes da malha urbana, também se expressou uma tendência ao acesso mais amplo à região central pelas camadas 
populares. No Bar Valentino isso se tornou sintomático com o incremento ainda maior na diversidade de seu público, quando os "manos", habitantes das longínquas periferias, passaram a marcar presença maciça no espaço. Observou-se, então, uma transformação nas formas de usufruir o lazer, na qual a presença do "outro" implicou na incorporação de hábitos mais característicos às grandes cidades, como certas ressalvas diante dos perigos que o desconhecido possa proporcionar; afinal, a cidade já não é mais aquela que se limita ao controle proporcionado pelo campo de visão: surgem novas áreas e outros atores sociais entram em cena. Como demonstrado, embora a maior parte dos freqüentadores mais antigos responsabilizem estes atores pela maior incidência de crimes e relações sociais violentas nos arredores do bar, algumas análises teóricas comprovam como essa associação é marcada pelo imediatismo. Pois, conforme tais análises, estes índices parecem estar mais relacionados a uma rede de ilegalidade bastante ampla, bem como à descentralização do município e à conseqüente dispersão dos investimentos em segurança, do que ao caráter "naturalmente perverso" das classes populares ou ao ambiente do Bar Valentino, e dos bares em geral: onde, muitas vezes, supõe-se não haver regras e nem outra moral que não a do "álcool” e a da "malandragem".

Já em seu novo endereço, análise etnográfica revelou que ao mesmo passo em que o Bar Valentino fixou-se no quadrante sul-sudoeste, acompanhando o fluxo das elites pela malha urbana, o espaço ganhou algumas características que o aproximam a um "enclave fortificado" - com destaque para a incorporação de um sistema de segurança bastante rígido, impessoal e homogeneizante. Neste sentido, apesar de o bar ainda comportar um público marcado pela heterogeneidade, que agora oscila entre a predominância de "manos" e/ou de "patricinhas" e "playboys" em determinadas noites, a diversidade de seus freqüentadores passou a ser extremamente controlada com o advento de filas, cadastros, revistas, grades, alambrados, preços altos e pela própria distância do Bar Valentino em relação ao núcleo central. Ou seja, o espaço ainda é aberto a todos, mas desde que sejam cumpridas as regras e que se mantenha a margem dos padrões vivenciados pelas camadas mais favorecidas da população. A julgar pelo próprio posicionamento dos usuários mais antigos do espaço, favoráveis ou contrários a estas mudanças, percebe-se que, sob um enfoque microscópico, o bar traduz um dilema vivenciado na atual fase de crescimento de Londrina: afinal, com o surgimento e a aproximação de diversos equipamentos urbanos aos "enclaves fortificados", o que 
supostamente se ganha, de maneira pontual e localizada, na redução das estatísticas referentes à criminalidade e à violência não seria também perdido em relação à profundidade e à espontaneidade dos contatos e das trocas sociais?

O segundo eixo tomado para a análise, composto pelo foco nas relações estabelecidas entre o Bar Valentino e o trânsito mais amplo de seus freqüentadores pela malha urbana, parece dar uma dupla resposta a essa questão. Para abstração dessas relações e para, nos limites desta conclusão, resolver este impasse, a noção de circuito mostrou-se como fundamental. Observou-se aqui, que enquanto o bar permaneceu na região central, por sua própria localização, o espaço tornou-se um ponto de confluência entre diversos circuitos derivados em meio ao circuito de lazer noturno em Londrina. Dadas as possibilidades e os limites impostos por uma cidade de porte médio, no qual tendencialmente as áreas mais afastadas ao seu núcleo central mostram-se pouco atrativas pela relativa ausência de equipamentos urbanos, o fluxo estabelecido entre o Bar Valentino e os demais espaços que compunham tais circuitos realizavam-se sob uma escala espacial e temporal mais reduzida - composta por um padrão "centralizado", com os trajetos concluídos em uma única noite.

Com a transferência do bar para o quadrante sul-sudoeste da cidade, alguns espaços de lazer encerraram suas atividades, outros surgiram e alguns mais assumiram maior importância em meio aos circuitos aqui considerados. Mediante o mapeamento e a abstração das regularidades expressas aos novos deslocamentos realizados sob a referência do Bar Valentino tornou-se perceptível a ampliação espacial e temporal dos trajetos e circuitos, que acompanharam a própria mudança de escala vivenciada atualmente por Londrina. Enquanto a disposição dos equipamentos urbanos e o fluxo entre eles denunciam a descentralização da cidade rumo ao sul-sudoeste - através da maior visibilidade adquirida por esta área no plano do lazer -, a aproximação do bar ao “circuito das "patricinhas' e "playboys" evidencia como esta região pode ser considerada como muito mais próxima às elites do que aos outros setores da população. Mas, além disso, como observado, a reconfiguração dos trajetos que compõem o circuito de lazer noturno em Londrina expressa também uma cidade que em seu processo de crescimento vive mais intensamente a experiência da diversidade, com maior possibilidade de escolhas, arranjos e combinações em meio aos fluxos de sua população pela malha urbana. 
Assim, ainda que a etnografia dos circuitos de lazer em Londrina venha a confirmar o caráter socialmente desigual da atual fase de expansão da cidade, em última análise, o que este trabalho demonstra é que com sua mudança de escala os encontros pela urbe não se encerram, mas se reorganizam mediante as novas possibilidades abertas por seu crescimento - sejam estas dadas pela "perda", pelo "ganho" ou pela "transformação" de seus espaços. Sob a perspectiva aqui adotada, o que a transferência do Bar Valentino parece denotar e que, quando se considera o foco mais amplo da cidade em sua própria totalidade, ainda que a crescente incorporação de equipamentos urbanos sob a forma de "enclaves fortificados" possa figurar como uma alternativa pontualmente eficaz em relação à diminuição da criminalidade e da violência - é necessário frisar, apenas para aqueles que os usufruem -, mesmo que segregada e desigual a experiência urbana, as trocas e os (im)previsíveis encontros persistem e se renovam a cada dia, a cada madrugada e cada "balada". Afinal, se como dizia o poeta "a vida é a arte do encontro", sabiamente complementa Straviski (2004) “o bar é o lugar". 


\section{REFERÊNCIAS}

ABREU, Carolina Camargo. Raves: encontros e disputas. São Paulo: Universidade de São Paulo, 2006. Dissertação de Mestrado em Antropologia Social.

ALMEIDA, Ana Maria Chiarotti. Participação social dos operários de origem rural em área urbana: Londrina - PR. Curitiba: Grafipar, 1981.

A morada do vale: sociabilidade e representações; um estudo sobre as famílias pioneiras do Heimtal. Londrina: Eduel, 1997.

ALMEIDA, Ana Maria Chiarotti; ADUM, Sonia Maria Sperândio Lopes. Memória e cotidiano do bosque. Londrina: Eduel, 2007.

ALMEIDA, Heloísa Buarque de. Janela para o mundo: representações do público sobre o circuito de cinemas de São Paulo. In: MAGANI, José Guilherme C. e Lílian de Lucca Torres (Org.). Na metrópole: textos de antropologia urbana. São Paulo: Edusp, 2000.

ARAÚJO, Fernando. Crianças são suspeitas por disparos em lan house. Jornal de Londrina. Londrina. 17.06.2008.

ARIAS NETO, José Miguel. O eldorado: Londrina e o Norte do Paraná. 1930/1975. São Paulo: Universidade de São Paulo, 1993. Dissertação de Mestrado em História Social.

BARNABÉ, Marcos Fagundes. A organização espacial do território e o projeto da cidade: o caso da Companhia de Terras Norte do Paraná. São Carlos: Universidade de São Paulo, 1989. Dissertação de Mestrado em Arquitetura.

BRIGUET, Paulo. O tempo de um bar. Jornal de Londrina. Londrina. 10.10.2004.

. O novo velho Valentino. Jornal de Londrina. Londrina. 01.04.2006.

CALDEIRA, Teresa Pires do Rio. Cidade de Muros: crime, segregação e cidadania em São Paulo. São Paulo: Ed.34/Edusp, 2000.

CARVALHO, Maria Siqueira de. Violência Urbana: breves considerações sobre a cidade de Londrina. In: Diez años de cambios en el Mundo, en la Geografía y en las Ciencias Sociales, 1999-2008. Actas del X Coloquio Internacional de Geocrítica. Barcelona: Universidad de Barcelona, 2008.

CASTELNOU, Antônio. Arquitetura londrinense: expressões de intenção pioneira. Londrina: A. Castelnou, 2002. 
CESÁRIO, Ana Cleide. Norte Novo: a expansão da fronteira e seu conteúdo simbólico. In: PAZ, Francisco Moraes (Org.). Cenários de economia e política: Paraná. Curitiba: Prephácio, 1991.

CHALHOUB, Sidney. Trabalho, lar e botequim: o cotidiano dos trabalhadores no Riode Janeiro da belle époque. Campinas: UNICAMP, 2001.

CUNHA, Fábio César Alves da. A metrópole de papel: a representação "Londrina metrópole" na institucionalização da Região Metropolitana de Londrina. Presidente Prudente: Universidade Estadual Paulista, 2006. Tese de Doutorado em Geografia.

DUMAZEDIER, Jofre. Lazer e cultura popular. São Paulo: Perspectiva, 1976. . Sociologia Empírica do Lazer. São Paulo: Perspectiva/SESC, 1999.

EVANS-PRITCHARD, Edward. Os Nuer: uma descrição dos modos de subsistência e das instituições políticas de um povo nilota. São Paulo: Perspectiva, 1999.

FANTIN, Márcia. Cidade dividida: dilemas e disputas simbólicas em Florianópolis. Florianópolis: Cidade Futura, 2000.

FILO: uma história (1968 - 1988 - 2000). Londrina: 2000.

FRAZÃO, Marcelo. Duplas de policiais desaparecem e população volta a ter medo. Jornal de Londrina. Londrina. 27.03.2008.

FRESCA, Tânia Maria. Mudanças recentes na expansão físico-territorial de Londrina. Geografia, Londrina, $\mathrm{N}^{\circ}$ 02, 2002.

. A rede urbana do Norte do Paraná. Londrina: Eduel, 2004.

FRÚGOLI JR. Heitor. Centralidade em São Paulo: trajetórias, conflitos e negociações na metrópole. São Paulo: Cortez/EDUSP, 2000.

GALEMBECK, Glória. Polícia Militar instala primeira câmera na próxima semana. Jornal de Londrina. Londrina. 30.03.2007.

GEERTZ, Clifford. A interpretação das culturas. Rio de Janeiro: Guanabara, 1989.

GIORGIO, Fábio Henriques. Na boca do bode: entidades musicais em trânsito. Londrina, 2005.

GOUVEIA, Guilhreme. Mundo paralelo: 24h no Terminal Urbano. Jornal de Londrina. Londrina. 07.10.2007. 
GRASSIOTO, Maria Luiza Fava; GRASSIOTO, Junker de Assis. A atividade comercial e sua relação com o urbano: o exemplo de Londrina. Semina: ciências sociais e humanas. Londrina, $\mathrm{N}^{\circ} 24,2003$.

HEILBORN, Maria Luiza. Construção de si, gênero e sexualidade. In: HEILBORN, Maria Luiza (Org.). Sexualidade: o olhar das ciências sociais. Rio de Janeiro: Zahar, 1999.

JANUZZI, Denise de Cássia Rosseto. O desenvolvimento de Londrina e as transformações nos espaço públicos da região central. In: Semina: Ciências Sociais e Humanas. Londrina, $\mathrm{N}^{\circ}$ 26, 2005.

KINDLEIN, Giovana. Londrina amada e festejada. Folha de Londrina. Londrina. 05.12.2004.

LINARDI, Maria Cecília Nogueira. Pioneirismo e modernidade: a urbanização de Londrina - PR. São Paulo: USP, 1995. Tese de Doutorado em Geografia.

LOYOLA, Maria Andréa. A sexualidade como objeto de estudo das ciências humanas. In: HEILBORN, Maria Luiza (Org.). Sexualidade: o olhar das ciências sociais. Rio de Janeiro: Zahar, 1999.

MAGNANI, José Guilherme Cantor. Festa no pedaço: cultura popular e lazer na cidade. São Paulo: UNESP/Hucitec, 1998.

Mystica Urbe: um estudo antropológico sobre o circuito neo-esotérico na metrópole. São Paulo: Studio Nobel, 1999.

Quando o campo é a cidade: fazendo Antropologia na metrópole. In: MAGANI, José Guilherme C. e Lílian de Lucca Torres (Org.). Na metrópole: textos de antropologia urbana. São Paulo: Edusp, 2000.

Os circuitos dos jovens urbanos. Tempo Social: revista de sociologia da USP. São Paulo, N², 2005.

De perto e de dentro: notas para uma etnografia urbana. [on line] In: NAUNúcleo de Antropologia Urbana da USP. Disponível via WWW no URL http://www.na-u.org/DEPERTOEDEDENTRO.html. Capturado em 23/05/2006.

Etnografia Urbana. Mimeo, 2007.

MAIA, Deise. Patrimônio cultural em Londrina: como os nativos pensam. Revista Estação. Londrina, $\mathrm{N}^{\circ}$ 4, 2005.

MARCELLINO, Nelson Carvalho. Estudos do lazer: uma introdução. Campinas: Autores Associados, 2000. 
MARINHO, José Aparecido. A história do Festival de Teatro de Londrina (FILO): 1968 a 2000. Curitiba: Universidade Federal do Paraná, 2005. Dissertação de Mestrado em Letras.

MEIRA, Thomás Antônio. Entre o estigma e o respeito: identidades (homo)sexuais negociadas em espaços de lazer. Londrina: Universidade Estadual de Londrina. Trabalho de Conclusão de Curso em Ciências Sociais.

MELLO, Paulo Thiago de. Pé sujo, o botequim em seu estado mais puro. In: Rio botequim: 50 bares e botequins com a alma carioca. Rio de Janeiro: Casa da Palavra, 2005.

MENDONÇA, Gisele. Valentino entra na maioridade. Jornal de Londrina. Londrina. 28.10.2000.

MOÇA é morta com tiros em frente ao Bar Valentino. Folha de Londrina. Londrina. 31.01.2005.

NAKAGAWARA, Yoshiya. As funções regionais de Londrina e sua área de influência. São Paulo: Universidade de São Paulo, 1972. Tese de Doutorado em Geografia.

NASCIMENTO, Ana Paula. Valentino em nova versão. Folha de Londrina. Londrina. 05.04.2006.

NAVARRO, Vanessa. Bares formam patrimônio afetivo de Londrina. Jornal de Londrina. Londrina. 05.12.2004.

05.04.2005.

Polícia alerta para estupros no Zerão. Jornal de Londrina. Londrina.

OURA, Karen Yukie. Verticalização em Londrina - Paraná: a produção do espaço urbano e seu desenvolvimento pelos edifícios verticais. São Paulo: Universidade Presbiteriana Mackenzie, 2006. Dissertação de Mestrado em Arquitetura e Urbanismo.

PEREIRA, Alexandre Barbosa. De rolê pela cidade: os pixadores em São Paulo. São Paulo: Universidade de São Paulo, 2005. Dissertação de Mestrado em Antropologia Social.

Perfil do Município de Londrina, 2003 (Ano base 2002).

PM instala “módulo móvel” no terminal. Jornal de Londrina. Londrina. 21.10.2007.

SATO, Nelson. Bar histórico vai mudar de endereço. Folha de Londrina. Londrina. 17.01.2003.

. Valentino em tempo de festa. Folha de Londrina. Londrina. 01.10.2004. 
SILVA, William Ribeiro da. A formação do centro principal de Londrina e o estudo da centralidade urbana. In: Geografia, Londrina, N², 2003.

- Centralidade e produção de loteamentos fechados na cidade de Londrina $P R$. Mimeo. S/d.

SIMMEL, Georg. A metrópole e a vida mental. In: VELHO, Otávio Guilherme (Org.). O fenômeno urbano. Rio de Janeiro: Zahar, 1976.

SPÓSITO, Maria Encarnação Beltrão. O centro e as formas de expressão da centralidade urbana. In: Revista de Geografia, São Paulo, N ${ }^{\circ}$ 10, 1991.

STECA, Lucinéia Cunha; FLORES, Mariléia Dias. História do Paraná: do século XVI à década de 1950. Londrina: Eduel, 2002.

STRAVISKI, Norberto. Pelos bares do Paraná: a vida é a arte do encontro: o bar é o lugar. Curituba: Palavra Viva, 2004.

TOLEDO, Luíz Henrique de. Lógicas no Futebol. São Paulo: Hucitec, 2002.

TORRES, Lilian de Lucca. Programa de Paulista: lazer no Bexiga e na Avenida Paulista com a Rua da Consolação. In: MAGANI, José Guilherme C. e Lílian de Lucca Torres (Org.). Na metrópole: textos de antropologia urbana. São Paulo: Edusp, 2000.

VELHO, Gilberto. Individualismo e cultura: notas para uma antropologia das sociedades contemporâneas. 7. ed. Rio de Janeiro: J. Zahar, 2004.

ZEQUIM, Maria Angelina. Muros invisíveis em Londrina: análise geográfica dos homicídios resultantes da violência urbana (2000 - 2002). Londrina: Universidade Estadual de Londrina, 2004. Dissertação de Mestrado em Geografia, Meio e Ambiente e Desenvolvimento. 


\section{OUTRAS FONTES DE PESQUISA}

\section{Acervos:}

Acervo do Museu Histórico de Londrina.

Acervo Fotográfico do Festival Internacional de Londrina (FILO)

Instituto de Preservação do Acervo Cultural de Londrina - IPAC/LDA

\section{CD-ROM:}

Reciclagem e Preservação do Patrimônio Edificado (CD-ROM, 2007).

Internet:

www.barvalentino.com.br

www.orkut.com

www.wikipedia.org

www.google.maps

www.youtube.com

www.n-a-u.org

www.pubs.com 